UC-NRLF

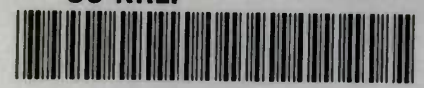

В 4521915

I R DS

USEFUL AND HARMFUL

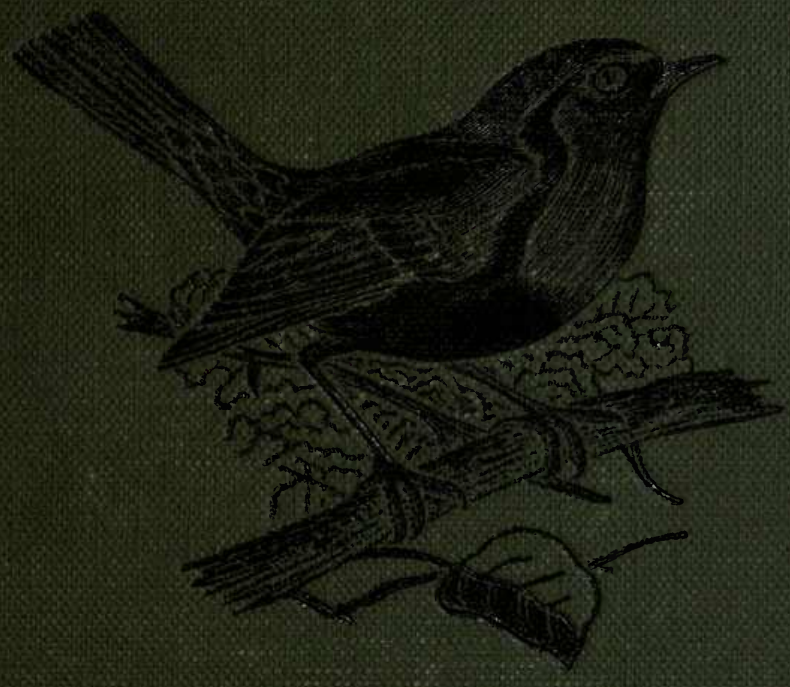

85 ILIUSTRATIONS 

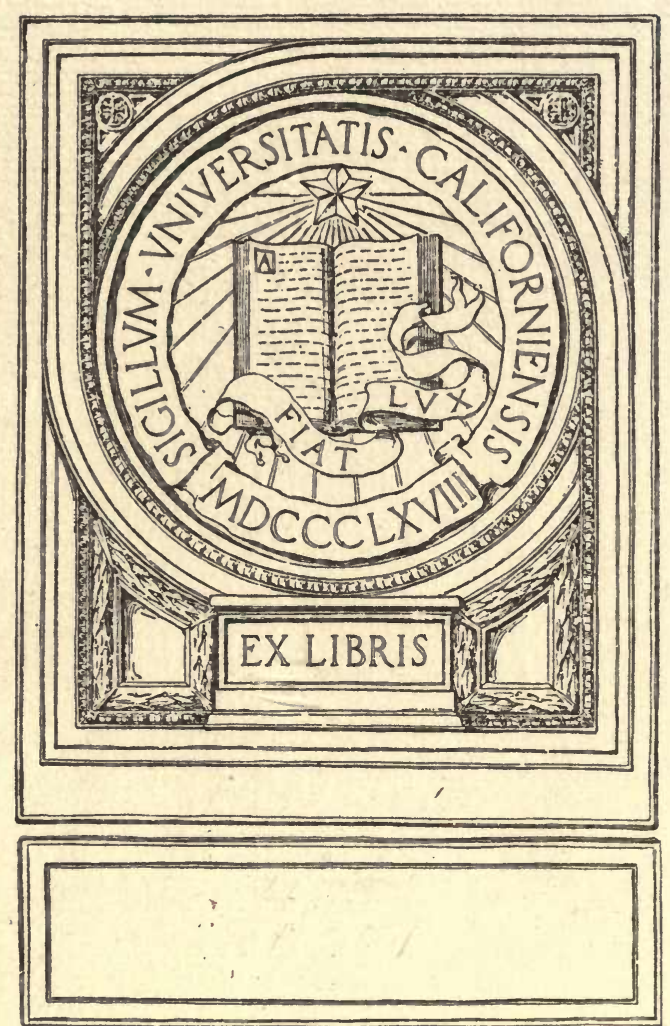


Birds Useful and Birds Harmful 
Sherratt \& Hughes

Publishers to the Victoria University of Manchester Manchester : 34 Cross Street London: 33 Soho Square, W. 



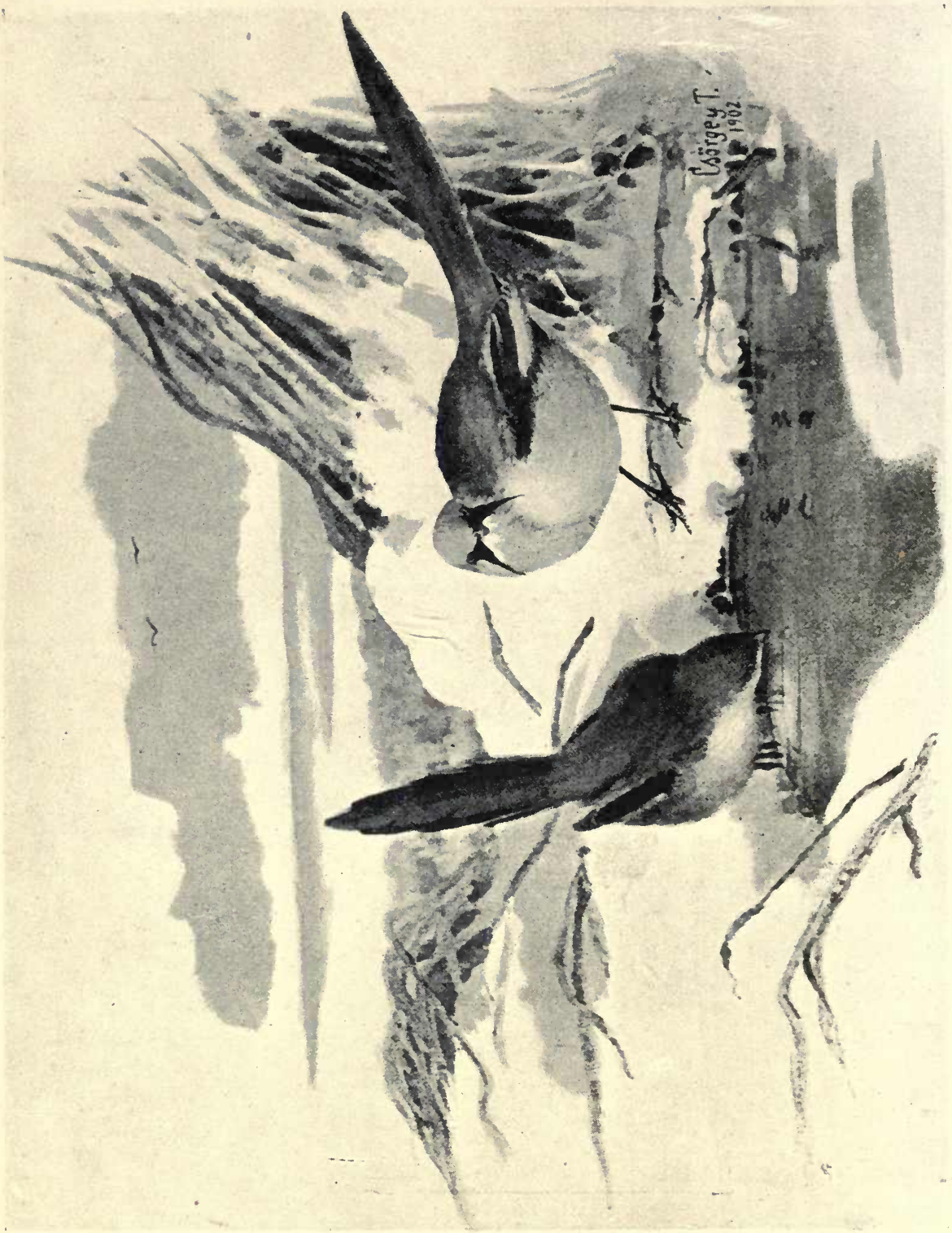

E

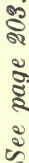




\section{BIRDS USEFUL}

and

\section{BIRDS HARMFUL}

BY

\section{OTTO HERMAN}

Director of the Royal Hungarian' Ornithological Bureau, Budapest

AND

\section{J. A. OWEN}

Author of the "Country Month by Month," etc., and Editor of all signed "A Son of the Marshes."

Illustrated by T. Csörgey.

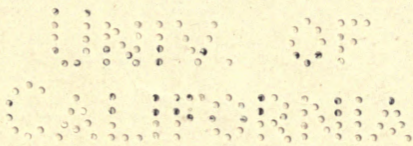

\section{MANCHESTER}

A t the University Press 
0.0995
115

औด $\because 3$

ar o 


\section{CONTENTS}

P'AGE

Preface

Chapter I. Useful or Harmful - - $\quad$ - $\quad 7$

Chapter II. The Structure of the Bird - _ - 15

Chapter III. Workers on the Ground - - $\quad 25$

Barn or White Owl, Tawny or Wood Owl, Longeared Owl, Short-eared Owl, Little Owl, the Rook, Hooded Crow, Carrion Crow, Raven, Jackdaw, Jay, Magpie, Quail, Black-headed Gull, Starling, Rose Starling, Waxwing.

Chapter IV. In the Air and on the Trees - _ IO5 Swallow, House Martin, Sand Martin, Swift, Nightjar or Fern Owl, Green Woodpecker,

Greater Spotted Woodpecker, Lesser Spotted Woodpecker, Tree-Creeper, Nuthatch, Crossbill.

Chapter V. The Farmer's Summer Friends - I 39

Wryneck, Cuckoo, Hoopoe, Great Grey Shrike, Lesser Grey Shrike, Red-backed Shrike, Lesser Whitethroat, Blackcap, Nightingale, Redstart, Tree-Pipit, Wagtails, Great Reed Warbler, Willow Wren, Flycatchers, Wheatear, Stonechat, Bearded Reedling or Titmouse, the Titmouse Family. 
Chapter VI. Workers all the year round 225

House Sparrow, Tree Sparrow, Hedge Sparrow, Skylark, Kingfisher, Dipper, Song Thrush, Blackbird, Oriole, Robin, Wren, Chaffinch, Hawfinch, Bullfinch, Yellow Hammer, Turtle Dove.

Chapter VII. Some Wildfowl - _ _ _ $\quad$ - 283

Lapwing, Common Curlew, Redshank, Green Sandpipers, Herons, Bitterns, Moorhen, Tern, Bean Goose, Wild Duck or Mallard, Pintail Duck, Shoveler, Great Crested Grebe.

Chapter VIII. Some of the Falconidæ - _ - - 333

Golden Eagle, Kite, Red-footed Falcon, Buzzard, Sparrow Hawk, Goshawk, Hobby, Kestrel, Marsh Harrier, Hen Harrier.

Chapter IX. The Rational Protection of Birds - 369 


\section{Preface.}

THE systematic study of the economic value of birds in their relation to agriculture has been carried out in Hungary of late years more indefatigably than in most other parts of Europe. The natural resources of the country are indeed so largely dependent on agriculture that this is only what might have been expected.

The Royal Hungarian Minister, M. Darányi, who has proved himself so thorough and so capable a Director of his country's interests in the direction of Agriculture-amongst other handbooks issued under his orders for popular use-commissioned the wellknown naturalist, M. Otto Herman, to prepare the present work, which is intended to give to landowners, farmers, fruit-growers and gardeners such a knowledge of the action, beneficial and otherwise, of birds as would prevent the mistakes which have ended in some districts in our own country, in the wholesale destruction of some very useful species. 
The book is enriched by the drawings of a talented artist, M. Titus Csörgey, who, I need not say, is himself a skilled naturalist. These are so executed as to render it easy to the most casual observer to identify the various markings of the plumage as well as the mere form of the bird.

The work makes no pretence at being scientific in the ordinary sense of the word. It has been written with the view of providing a ready handbook for the farmer, the gardener, the student, and bird-lovers generally; and it embodies the result of exact data kept by correspondents of M. Herman's department in all parts of the country; so that the observations on which its statements are grounded are the results of personal investigation and dissection.

In our country this study of the food of birds and the part they play in the economy of nature has not received the attention it demands. Yet it is one that affects the entire community. It is true that in journals here and there valuable papers on this subject have appeared, but it is felt that among the innumerable books on bird life which have been published of late years there has been a lack which this little volume may supply.

A few words as to myself and my present association with M. Herman. From my earliest childhood I have had a passionate love for birds and flowers. I remember looking with wondering delight on the velvety upturned faces of the variously tinted pansies that bordered the paths leading up to the door of a certain farmhouse where we stayed much in the summer-time, when I was just four years old,-wonder because our mother told us' that God's finger painted them and I used to think that He did it whilst we slept. Our father gave us 
prizes for the one who could collect the greatest number of wild flowers and knew most about the trees. In the town I collected bird pictures, nursed an occasional wounded sparrow, kept my eyes open generally, and read much of William and Mary Howitt. Then came some years of school life-the last two of these in Germany, where the study of natural history has always received more attention than has hitherto been the case with us in England, and these were followed by a few years at home on the moorlands of Staffordshire. Later I had thirteen years of wandering in different parts of the Pacific-New Zealand, Tahiti, Hawaii, California, all of which strengthened my love of out-door life; and although my scientific knowledge was small, my acquaintance with nature and my love of nature have been ever growing.

As years advanced, and I was no longer able to go so far afield, it has been a great pleasure to me to collaborate with other naturalists-more than one of these-who, with greater opportunities for the practical observation of birds have combined scientific research. I have been glad to act as henchwoman to such--and to be, as it were, the little bird that in its playful and circling way follows the flight of the greater bird in the heavens.

And as I edited-with much gain to my own knowledge-the records of observations of the working naturalist styled "A Son of the Marshes," so I am glad also to be able to present to our English readers these chapters on the Man and the Bird, and their relative significance in the great field of agriculture.

I visited $M$. and Madame Herman at their home in the beautiful Hungarian valley of Lillafüred, where his 
summers are spent in the very heart of nature; and 1 learned and saw much with him there. He had lived as a boy among these mountains and valleys-his father having been the leading physician in the district. There, he had scoured the woods over which the Snake or Short-toed Eagle circled, climbed up to the Peregrine Falcon's nest, and boated on the lovely little lake, watching the movements of the Osprey. But indeed his whole life has been devoted to the study of nature, and the fauna of his Country, and his many published writings have had a very large circulation there, as well as in Germany.

M. Herman laments the constantly decreasing number of birds in his native valley. In a spot where he once counted many a Flycatcher's nest, only two pairs now breed. The Nightingales, formerly plentiful, have entirely forsaken this valley--the Titmice are lessening in numbers, and so on. Yet the masses show no inclination to destroy useful, insect-eating birdsalthough modern forestry, and gardening, which does not tolerate old trees, and the absence of sheltering hedges over the great Hungarian plains, render many birds-especially the migratory species-homeless.

Numbers of interesting species nest in and visit this valley, however. In winter that beautifully coloured, long-billed Rock-Creeper (Tichodroma muraria) - with wings rose-red above, dashed with white underneath, runs up the rock sides, as does the Tree Creeper on the tree trunks - a blithe, busy creature. This species is found in the same latitude, in rocky mountain ranges eastward, as far as Northern China. The great slanting rocky spurs, that gleam with rosy light, or pale blue, as the sun runs its daily course, this rock climber delights in. The 


\section{PREFACE}

Rock Thrush breeds in the same ridges; the Long-tailed Tit has its nest there; near the ground in the woods, are the breeding-places of the familiar Coal-Tit; where fir-trees abound it is at home. The less welcome Red-backed Shrike pursues his cruel little methods here, lessening the numbers of more useful and more attractive birds. Waterfalls abound, and among the brooks, from stone to stone, trips the merry Dipper, showing his pretty breast and red underparts-building his large house near the running water, in whose pools fine trout are in plenty.

We have rested together in a little cove on the lake at Hamar, which is overhung by luxuriant foliage; across the water, over the dense woods, floats a solitary Eaglethat seeks his quarry in the shades below. Otto Herman knew his breeding-place as a boy. Tradition says the nest is at least a hundred years old, yet each year the young are still fed there.

That Great Britain has still much to do in the direction of Bird Protection is definitely shown in a leaflet just issued (December, 1908) by the Royal Society for the Protection of Birds, of whose Council I have the honour to be a member. Of the 370 or 380 species placed on the list of "British birds," scarcely 200 can now be justly termed British. I may be allowed to give you here some idea of the principal agents in this destruction of birds as set forth by our Society :-

" First, there are those who destroy for destruction's sake; the boy who ravages the hedgerows in spring and delights in catapults, air-guns, and stones at all times; the lout with a gun; and the cockney sportsman. They are responsible for a vast amount of cruelty, especially 
to nesting birds and nestlings; for the killing of various home-birds and migrants, and for the senseless shooting of sea-birds and occasionally of rare visitants.

"Secondly, the bird-catcher, responsible for the decrease of all those birds sought for caging, such as Goldfinch, Linnet, Siskin, Lark, etc. This class, like the first-named, requires dealing with, chiefly because of the intolerable amount of ill-treatment involved by the methods employed in the catching, transit, and sale of wild birds. The destruction of the useful Lapwing, and of the Skylark for the table, is also a point in need of attention; and in the same category may be placed the so-called sparrow-clubs, which encourage the indiscriminate killing of many species of small birds.

" Thirdly, the gamekeeper, responsible for the extinction, or extreme rarity of most of our large birds, especially predatory species and uncommon visitors.

" Fourthly, the private collector with a craze for rare British-taken birds and eggs, or, in the case of the humbler persecutor of beautiful species, for something to put in a glass case.

"Fifthly, the trader and the feathered woman, jointly responsible for the devastation wrought among the loveliest birds of all lands."

We have included a few useful species here, which are only visitants to our country, but which, with more protection, might remain for part of the year with us regularly. 


\section{CHAPTER I. \\ USEFUL OR HARMFUL?}

The Hungarian Central Office for Ornithology was instituted in $\mathrm{I} 804$, in accordance with a scheme submitted to the Ministry of Agriculture by Mr. Otto Herman, then a member of the Hungarian Parliament.

The rapid progress of economical affairs in the nineteenth century, particularly in its second half, had a perceptible influence upon the position occupied by the bird and insect fauna, a change which was felt in agriculture, and led to the formation of a new branch of science-ornithologia oeconomica.

The Hungarian Central Office for Ornithology took the new branch in hand, after its transfer from the sphere of the Ministry of Public Instruction to that of the Ministry of Agriculture, where $M$. de Darányi assigned an important place to practical experimental methods as a complement to strict science.

In the meantime Baron Hans von Berlepsch of Seebach developed his system for the protection and propagation of the most useful birds, the main points of which were the feeding and providing with nesting opportunities of such birds. Thereby bird protection was diverted into a rational direction, which met with hearty sympathy on the part of M. de Darányi ; consequently the Hungarian Central Office for Ornithology included this branch of ornithology in the work it set itself to do.

The course followed by rational bird-protection in Hungary is as follows. It starts with the idea that 
nature itself knows neither useful nor noxious birds, but only necessary ones, which have developed according to the laws of nature, and on the basis of their development are performing in the world of nature the work which is appropriate to their organism.

The manifold character of the work performed by birds is in harmony with the variety of these organisms.

The question of the usefulness and noxiousness of birds during the whole of the nineteenth century was treated only approximately, upon the assertions of authorities. When, later on, Congresses began to embrace the cause of bird-protection, and the question of the usefulness or noxiousness of each species assumed a rôle of the first importance, it turned out that there was no firm basis upon which to rely, in passing judgment. Eminent ornithologists were often at variance with regard to the usefulness or noxiousness of a particular sepcies.

Where Nature is intact, the number of birds is automatically regulated in accordance with the natural development of their surroundings.

The conceptions of "useful" and "noxious" are merely human ones; and man can, by cultivation or the contrary, alter the normal conditions ; and may, consequently, modify the character and habits of birds also. Agriculture on a large scale, modern forestry, the draining of territory-all these things alter the fundamental conditions of animal life, and in consequence of bird-life also; and if these modifications in respect of birds are injurious to man, it is in the interests of man to adapt them artificially for the benefit of birds; and if by cultivation man deprives useful birds of their natural nesting facilities, he ought to provide them with 
artificial ones. This is the principle on which Baron von Berlepsch founded his system, which was accepted and applied in Hungary, together with the modifications required by special circumstances, or such as were introduced as the result of experience.

These principles apply chiefly to those species which remain with us during summer and winter alike, and which are useful to agriculture. But the international protection of birds is important as regards those useful species that are migratory, and, as they migrate, pass through countries where as is the case in Italy-the birds are caught en masse, and where bird-catching is carried on as a trade.

The third international Ornithological Congress, held in Paris in I9oo, decided that the Governments of the various European States should be called upon to have the food of birds made the object of special investigations, and to report the result, within a space of five years. When the fourth International Congress met, however, only Hungary and Belgium were able to report on the subject.

The publications of the Hungarian Ornithological Centre are founded upon the collection of data, divided into two main groups:- $\mathrm{I}$. The Migration data, socalled historical, up to I89I, and again from that to the present day. 2. Foreign data, partly taken from literature, and Special data relating to one species, from the whole area of its habitation-the Cuckoo for instance.

The investigation of the economic rôle played by the Rook (Corvus frugilegus L.), which English landowners and farmers are beginning to feel is a matter of great importance, was begun by the Central Bureau in I893; it is still going on. According to the results hitherto 
attained, this bird does more good by destroying insects, and in particular the larvæ of insects living underground, than it does harm to the crops.

It is our endeavour in this little volume which we now offer to English readers, to give a faithful presentment of the good and the harm that the birds are known to do, from the agriculturist's standpoint. But in this all depends on the attitude which the gardener and the farmer adopt towards the birds.

By throwing a single stone a lad can scare away a whole flock of rooks; and when these birds alight on a field where they do harm to grain, a man must not grudge a little labour in keeping them off; considering that the same bird that works harm at one season, will be a valuable ally at another, as well as a source of pleasure and interest.

The rook, the crow, and even the mischievous magpie, follow the plough as it turns up the brown furrows, with sharp eyes spying worms, larvæ and cockchafer grubs. Nothing escapes the attention of the bird. He picks here and there, and fills his crop with the worst enemies of the tiller of the fields-the various forms of insect life that lie dormant in the earth until the time arrives for each one to come forth and fulfil its life's mission-much of which means injury to the fruit of man's labour.

Starlings rise in flocks-a perfect cloud of them-to disperse, and again to assemble before settling on the pastures, where they will be busy all the day, for that part of the year when man needs their services most.

Later, in the cherry trees and among our own vines the starlings would do mischief enough. The rifled branches and stripped grape stems are a sorry sight for 
the owner, who finds it hard to remember that God cares even for the sparrows. He tries to drive the thieves away, but they care little for the cries of the lads set to scare them. Little do they heed the rattles, feathers, rows of sticks with lines of thread-all the various flimsy inventions are useless; a gun will disperse them for the moment, but the cloud of pilferers is soon back again, and as busy as ever. At this juncture severe measures are justified. Even the most ardent bird-lover will not be foolish enough to protect every bird at all times and seasons. Yet it is only for a short season of the year that starlings are harmful, and for the greater part they are useful, in garden, field and meadow, from early morning until late evening, protecting growing blades of grass and coming seed and roots for the farmer, with unceasing labour. This is in the early spring; later they betake themselves to the pasture lands, where, on bright sunny mornings, they walk nimbly among the browsing cattle seeking their food in the form of crane fly and daddy-long-legs, in the shadow of the patient creatures. The gadflies, too, buzz about the bodies of the beasts, lay their eggs under the hide, boring into the flesh, tormenting and maddening the helpless cattle. The Hungarian herdsman is glad when he sees the starlings settle on his wide pastures.

When the eggs have developed into maggots the birds alight on the backs of the beasts, to rid them of gadflies and batflies; and the cattle and sheep suffer their services gladly, knowing well that these good feathered friends will effectually extract their torturers without further irritation to the infested parts. A horse has been known to die from the exhaustion caused by the continuous action of parasitic creatures. 
Then, as regards the owl - that bird of the night, who shuns the light of the life-giving sun; for which reason man distrusts and persecutes him. The other birds also regard him with disfavour, and mob him when he ventures forth from his holes by day, big birds and little ones, in common dislike of the uncanny creature. They know full well that this is the nocturnal disturber of woods and fields, and they resent his ways and his manners.

When the twilight is over all and the birds of day have betaken themselves to rest, then most of the owls go forth to hunt for quarry. Noiselessly they flit over the quiet meadows and fields; with those eyes which shun the light they can detect through the dimness of evening the nest where small birds are, and this they rifle. And so in that respect they are harmful. The Short-eared owl will take birds from the size of a lark to that of a plover.

On the other hand, when mice have got the upper hand in house and barn, devouring and spoiling man's provision, then every species of owl is welcome, even he the superstitious countryman calls the Death-bird. And, again, when the weather favours that pest the field-mouse, and the voles, and they swarm in meadows, cornlands and everywhere, so that the land is full of mouse-runs; from all sides comes that gentle singing from tiny throats and the farmer is at his wits' end to know how to be rid of the plague. Then in Hungary the mouse buzzards circle by day over the pastures and fields, making war on the gnawing little beasts; and the whole night long the owls take up the same useful work. They fill their crops, each of them, with from twenty to thirty mice, fly to their several 
trees to digest the meal, and you will find the pellets formed by the birds of the indigestible portions-bones and fur-in and about their nesting-holes. Harmful moths and beetles they also kill.

And so the Owls - barn, the tawny or wood-owl, the long and the short-eared-which in England are the only common species, are undoubtedly the agriculturalists' good friends, and indeed friends of the whole human race; and many landowners now prohibit the use of the cruel pole-trap in their destruction. Richard Jefferies tells how 200 owls were taken in one pole-trap in a plantation of young fir in his time. Dr. Altum, a great mover in the cause of bird-protection, examined 2 Io of the wood-owl's pellets and found in these the remains of 6 rats, 42 mice, 296 voles, 33 shrews, 48 moles, I 8 birds and 48 beetles, besides a countless number of cockchafers.

And what can you find to say in favour of the Sparrow? I fancy I hear many a reader ask, - that ubiquitous bird whose impudence is everywhere proverbial. When sparrows in hosts settle down on the corn waiting to be harvested, not only filling their crops but uselessly beating the grain out of the ears, the case is bad, and it is hard then to recall all the good the same birds had done in devouring the seeds of harmful weeds, such as wild mustard, etc.--also to think of the cockchafers in the grub as well as winged - daddy-longlegs, caterpillars, turnip-moth, grubs of cabbage-moth and butterfly, and the moths of both currant and gooseberry. In towns, too, the sparrow is invaluable as a street scavenger. House-flies, those plagues indoors, maggots of fleas, eggs of cockroaches, spiders, centipedes, - all, and many other " small deer " that infest 
stables, poultry-yards and other precincts of our homesteads the sparrow diligently seeks for.

It is true that the common sparrows multiply too fast and their numbers must be thinned down. This, many a bird-loving landowner and farmer does in various ways. The late Lord Lilford declared the most humane way was to pull down all the nests within man's reach. There would still be plenty left, in inaccessible places. A humane farmer, the present writer knows in Hampshire, a great wheat-grower, gives the lads round threepence a score for all the sparrows' eggs they can bring to him. Sparrow-clubs-save the mark!-are schools for cruelty. In one Lancashire parish which I know the vicar encourages the Jackdaw, allowing it to build even in his church steeple, because wherever that bird is, sparrows become more scarce, their young suiting that bird's palate well. Man has foolishly upset the balance of nature by destroying the natural enemies of the sparrow. Take two neighbouring estates we know in Yorkshire; on the one sparrows, blackbirds, bullfinches and other birds are remorselessly shot during the fruit season; on the other the use of the gun is forbidden. In the garden and orchard of the latter there is always a far greater allowance of fruit than in those of the former.

Only where their natural enemies have become scarce ought man to set his wits to work to compass the destruction of a species. 


\section{CHAPTER II.}

\section{The Structure of the Bird.}

LET us now consider the bird's bodily structure. Every child knows that the bird's body is covered with feathers or down, and that what, in the case of mammals are fore-feet, in birds are wings with which they fly.

There are as many kinds of flight as there are kinds of birds. It depends for the most part on the nature of the bird, in a smaller degree on the structure of the wing.

The wing of the Swallow (Plate VIII.a) is pointed like that of the Peregrine Falcon, and is adapted for rapid flight. Both these birds secure their prey on the wing, and could not, therefore, live otherwise.

The wing of the Partridge is, on the contrary, rounded; this bird does not cut through the air, but can only raise itself in flight with rapid fluttering of the wings, and with a sudden loud "whirr" which makes considerable noise if the covey is a large one. The wing of the Partridge, therefore, is not at all adapted for enabling the bird to catch its prey flying, but only for moving from place to place, where it picks up its food walking.

From this we learn that the various kinds of wings correspond to various ways of flight and that each bird works out its destiny in its own way. It is suggestive of the organisation of an army, composed of cavalry, infantry, artillery, and other divisions. These also have different kinds of functions, which are necessary both 


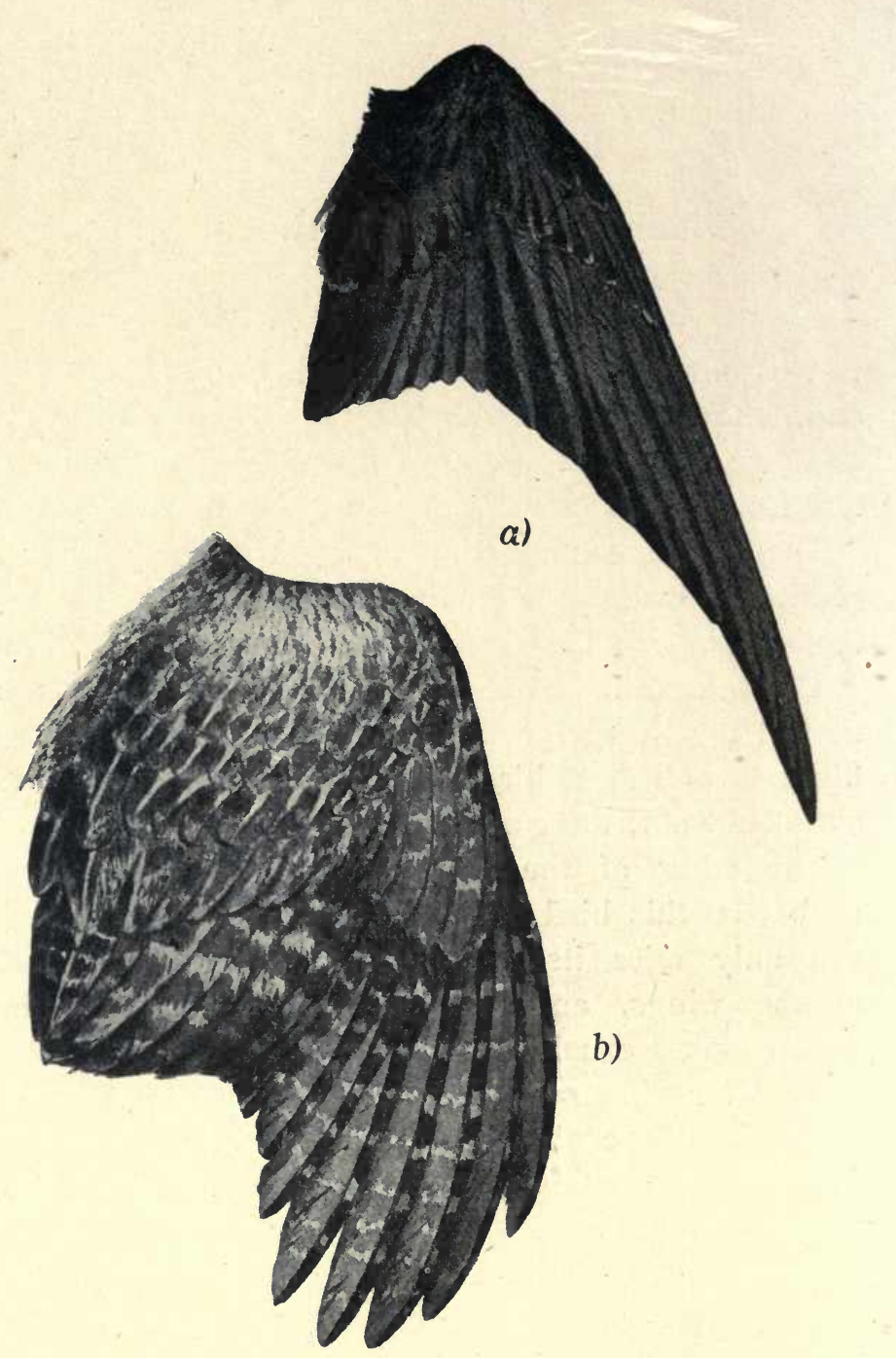

(a) SWALlow's Wing; (b) THAT OF THE PARTRIDGE. 
individually and in combination, and the one cannot supply the place of the other.

So much for the wings. Now we will examine Plate IX., which shows heads and-what is the most important part of them-bills. We will take the illustrations in their proper order.

I. The bill of the Woodcock is shaped like a turner's auger, the end greatly resembling the tip of a finger. With this the bird gropes for its food, and draws it out of the loose earth.

2. The bill of the Merganser has a hook at the point; it is toothed at the side, and is so well adapted to its purpose that no fish, however slippery, can escape.

3. The bill of the Hawfinch is conical, thick and strong, capable of cracking the hardest cherry stones.

4. The pretty Water-Wagtail has an awl-shaped bill, formed by Nature for the catching of gnats and other insects.

5. The Grey Heron has a bill which cuts like a knife. Woe to the most slippery tench if once caught within it!

6. The Curlew penetrates into the mud with its sickle shaped, slightly curved bill, and brings out of its depths the worms it feeds on.

7. The bill of the Long-tailed Tit is but a little point compared with those mentioned above, but all the same it is quite suitable for the bird, for only with such a tool could it pick the tiny insects out of the smallest cracks in the boughs.

8. The bill of the Goatsucker or Night-hawk is small, but the opening of the mouth is comparatively gigantic: it forms a yawning abyss, which, in the twilight and darkness of night, engulfs unwary insects. 


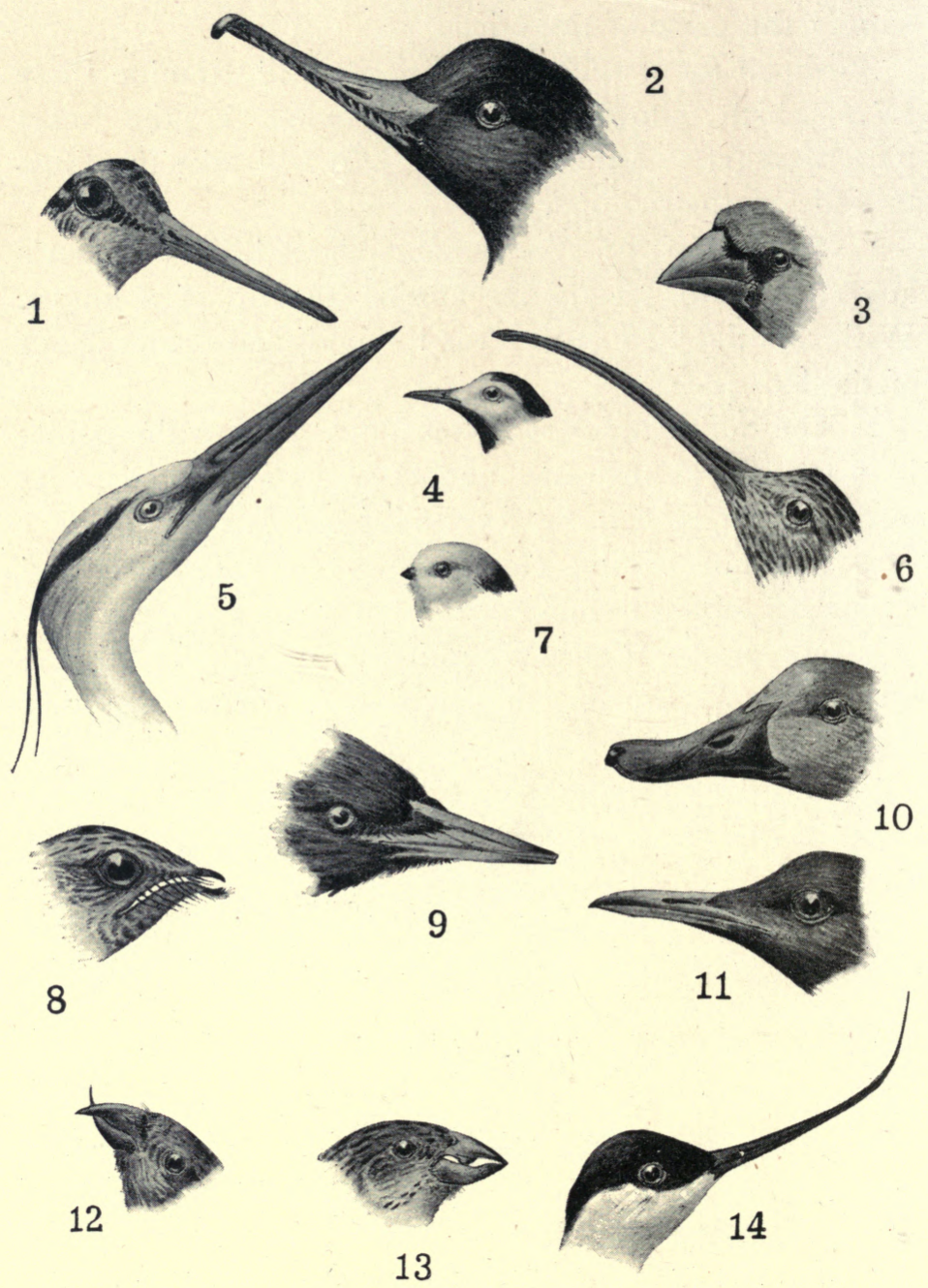


9. The bill of the Woodpecker may be compared to the adze which the Carpenter uses for chipping beams of wood. It is only by means of hard blows that this bird can get at the worms which it finds in decaying wood.

Io. The Duck's bill, on the other hand, is flat toothed at the side, exactly formed for straining the food which it gets out of the water.

I I. The bill of the Gull is so formed that it can easily take up food; from the surface of the water. Where Gulls arrive in large flocks, they eagerly follow the plough in the fields, and are then of great benefit.

I2. The bill of the Crossbill is a valuable tool, with which he is able to pick out the seeds from between the scales of the fir cones.

I3. The Ortolan splits hard seeds with the arch and the notch in its beak, as it were with nut-crackers.

I4. The bill of the Avocet is in shape the opposite of the Curlew,-that of the former curving upwards, of the latter downwards.

Thus we see that as with the wing, so with the bill,each bird is furnished with the kind that is most suitable to its nature and habits.

The general law of adaptability to its purpose is also strikingly exemplified in the formation of the foot. Let us look at Plate X.

I. The foot of the Fieldlark has a spur-like nail on the back toe which is nearly straight, so that the bird can easily rest on the ground.

2. The Pheasant's foot is just like that of the Hen; which enables it to walk and run.

3. The powerful, sharp claw of the Eagle strikes deeply into the flesh of its prey and holds it fast. 


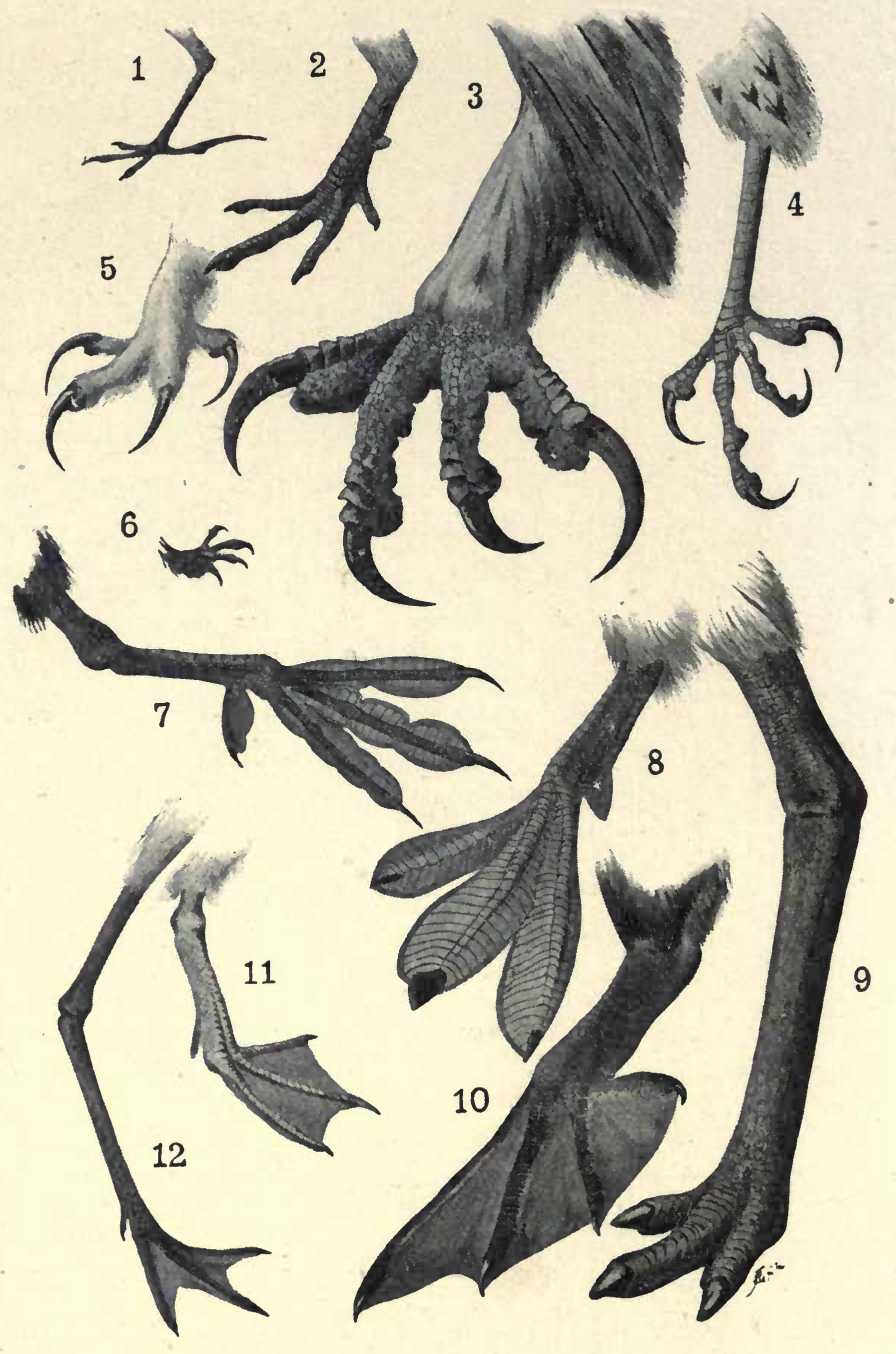


4. The Sparrow Hawk strangles and crushes with its warty toes the birds on which it preys.

5. The foot of the Owl, as well as its bill, proves that it is a bird of prey.

6. The foot of the Swift is so constructed that it can cling to walls; it cannot walk or stand.

7. The toes of the Moor- or Water-hen are provided with skin-flaps, not altogether perfect for swimming, but excellent for wading and diving.

8. The Crested Grebe excels in diving, pushing sideways with its feet.

9. The foot of the Bustard has three toes, and hard soles, which enable it to run extremely well.

10. The four toes of the Cormorant are joined together by a web; it is a good diver, can swim under water, and can also roost on trees.

II. The Wild Duck has only three toes webbed together; its foot is, therefore, specially suited for propelling the bird on the surface of the water.

I2. The toes of the Avocet are only partially joined together by webs; its legs are suitable only for wading, but can be used for swimming in case of need.

The variety and suitability to their purpose of wings, bills, and legs, show us that the feathered inhabitants of a neighbourhood form a community. A society of men would not be perfect if there were only men of one calling. A variety of workers is needed in human society, with a variety of tools, with which to perform a variety of necessary work, just as various birds with a varied construction of body perform their work in the open field of Nature. 
A FEW words as to the feathers of the bird. The perfectly developed feather consists of a quill which grows in the flesh, the stem becoming gradually thinner towards the top and having lesser feathers on either side, those on the one side of the quill being narrower than those on the other half. The feathers overlap each other exactly and densely especially those which protect the main part of the body. At the end of the quill of the top feathers is a down which takes the place of our underclothing, and which in the case of waterfowl prevents the water from penetrating to the body of the bird. There is also a pure down which is composed of numerous stems; this is close

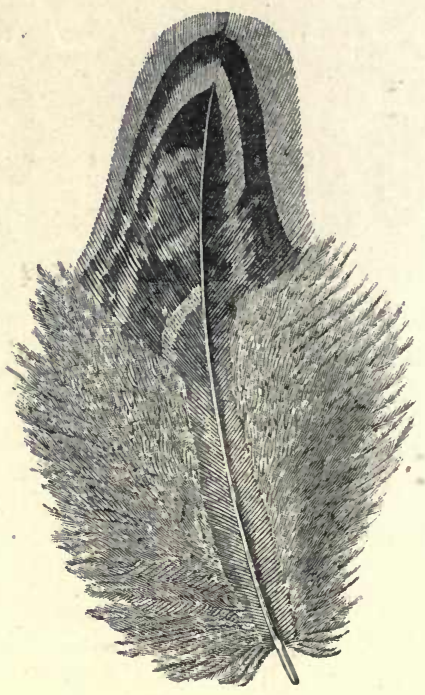
and thick and protects the binding together of the general plumage. The down has its fine quill and a stem bearing the close down which in water fowls keeps the warmth of the body at an even temperature whether

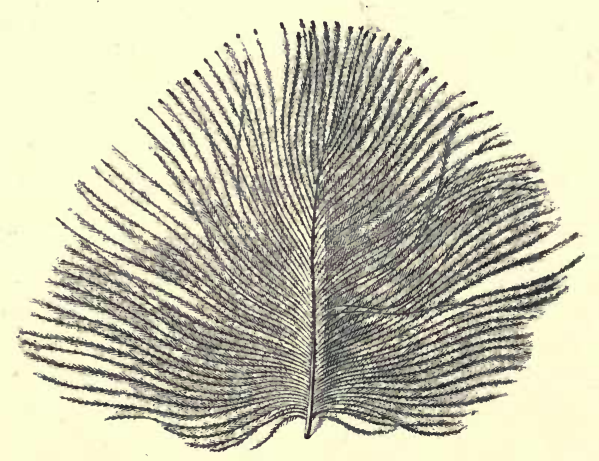
in or out of the water. It would be an error to suppose that the feathers grow in the skin without any order, simply close together. They are in point of fact divided into areas between which the flesh is generally 
covered with down, and all is arranged in a system of grouping which, the feathers being rightly placed over one and another, does not in any way interfere with the movements of the body, each movement being in perfect conformity with this feather covering. The feathered areas can be moved independently with the aid of the muscles, and this renders the cleansing of the individual feathers easy and the removing of the fatty substance, which is a matter of great importance. If we watch we see that the bird moves the feathers separately in this cleansing process, drawing them through its beak, and so removing any bits of fat and oily substances that may have collected about the fat glands.

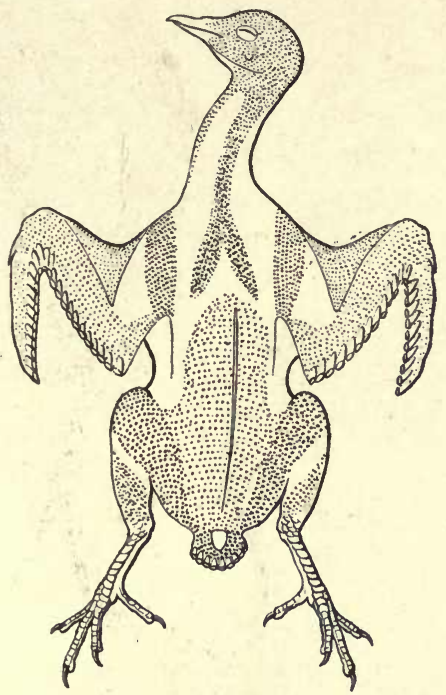

View of the back of the bird, showing the feather tracts.

The spaces between the tracts are covered with down. 


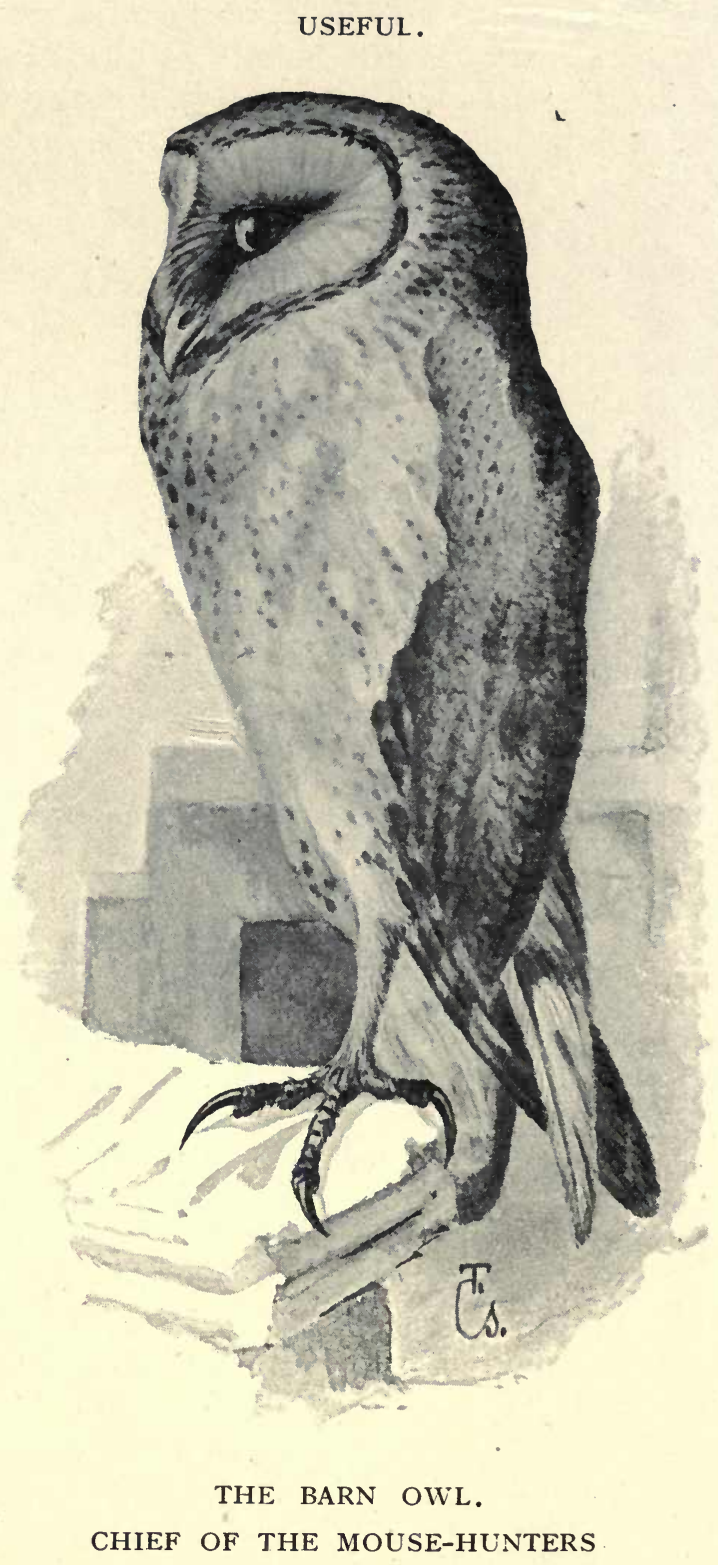




\section{CHAPTER III.}

\section{WORKERS ON THE GROUND. \\ The Barn Owl: White or Church Owl. \\ (Strix Flammea.)}

THE Barn Owl builds no regular nest, but lays its eggs in the walls of ruined castles, on the inner sills of towers, or in the dust and sweepings that collect in the corners of granaries. The clutch consists of five, occasionally seven, longish white eggs.

This bird likes always to be close to the abode of man; she likes to make her nest among the rafters of some warm barn and in other farm buildings, or in church tower or belfry; in hollow trees, a cleft in wall or cliff; semi-obscure corners, those even in broad daylight. There she sits, putting herself now and again in grotesque positions, and when that facial disk is stirred she appears to be, as the children say, "pulling faces" at you. One of the most industrious of hunters, she catches far more mice than she can devour. It is true she takes the bat, who has his own insect-destroying work to do; and when she has the chance she will cause havoc in the nest of a small bird. But this is only an occasional outbreak, and it must not weigh against the general good record of this most useful species. She takes living prey, and will only touch carrion under extreme stress of hunger. 
The Barn or White Owl is generally distributed throughout Great Britain. It suffered at one time most undeservedly from the ignorant prejudices of many gamekeepers, and of late years from the senseless fashion of women wearing the wings and head in their headgear -a crowning folly only perpetrated through that ignorant vanity which knows neither love nor pity.

Colonel Irby said that this Owl, which is most useful to man, can be preserved and increased by fixing an I 8-gallon cask in a tree. The barrel should be placed on its side and have a hole cut in the upper part of the head for the Owls to enter; care must, however, be taken that Jackdaws do not take possession of the cask.

Our gamekeepers are beginning now to be convinced of the usefulness of the Owl, especially in view of the fact that so many young birds are taken by the Brown Rat, a favourite quarry with the Owl-not to speak of the Voles and Mice the bird devours. The late Lord Lilford told me that he had watched a nest of young Owls being fed by their parents in an old cedar tree in the rectory garden of a relative, and that on one occasion the old birds came bringing food to these seventeen times in half an hour by the clock, on that evening. There was a rickyard not far from the nest which was the Owls' favourite hunting-ground. Mice were not plentiful there, but rats swarmed, and the pellets found under the nest were here composed almost entirely of the remains of the latter. In the South of France and in Spain this Owl is accused of drinking oil from lamps in the peasants' houses and in the churches and chapels. The name given to it in the former country by the peasant of the Midi is Béou l'oli-bird that drinks oil. Attracted by the light of the lamps, the poor Owl 
perhaps has entered, once in a way, and in its fright has upset a lamp. Superstition grows on very meagre fare. This ally of the agriculturalist has been ill-repaid for his services.

Butler writes :--

"An Owl that in a barn

Sees a mouse creeping in the corn,

Sits still and shuts his round blue eyes

As if he slept, until he spies

The little beast within his reach,

Then starts, and seizes on the wretch."

" Not a bird of the forest e'er mates with him,

All mock him outright by day,

But at night, when the woods grow still and dim,

The boldest will shrink away."

But why this is so who can tell? If the Barn Owl shows himself by day, Rooks and Starlings, Blackbirds, both species of Thrush, Chaffinches, Tits and Wrens will mob him; and he flies awkwardly from tree to tree, with dazed eyes and apparently "mazed," as the country folks says, altogether, till he can find a hole in a tree where he can hide himself. He may well like hollows in trees-for, as the poet says, " the Owl, with all his feathers, is a-cold." This is not hard to understand, for the breast feathers are so light and fluffy that the wind easily parts them, laying bare the shivering skin.

His frequent choice of an old dovecote as a home was misunderstood. The ignorant countryman thought it was in order to prey on the young pigeons that he selected a corner there, whereas-and Waterton was the first to record the bird's reason, after watching the doings of a pair of Barn Owls in his dovecote-the Owls were 
there to prey on the pigeons' enemies, and Owls and Pigeons lived amicably together in the same home.

Lord Cathcart, in a paper contributed to the Royal Agricultural Society, said: " Our ancestors, wiser than we, always made in their great barns ingress for Owlsan owl-hole, with often a stone perch." And the Rev. F. O. Morris tells of a pair of this species which lived in a barn near Norwich, and were so fearless that they would stay there whilst the men were threshing; they waited on the flails as rooks do on the plough, and if a mouse were dislodged by the removal of a sheaf they would pounce upon it without minding the men's presence. They hunt mice amongst the stacks, too, in the farmyard, staying there all night often, if mice abound. As E. Newman says, "The farmer pays the price of a sack of grain for every Owl nailed to his barn door, because that Owl would have destroyed mice every night, and these mice, being relieved of their oppresive enemy, would, in a very short time, consume a sack of wheat, peas, or beans."

Owing to its very deep plumage, the Barn Owl looks larger than it is. Its eye is dark-coloured, almost black : its glance is directed forwards. The facial disk is very prominent; at rest, it is heart-shaped, and it is edged with white and rust-colour. The bill is yellowish in colour, and is slightly hooked. The legs are scantily feathered, and the toes almost bare: the claw of the middle toe is serrated along its inner edge. The bodyplumage is soft as silk, and yielding, and thickly pearled with white and dark markings on the beautiful ash-grey back. The flanks are pale with a reddish tinge, in places very bright, and sprinkled with tiny pearl-like spots of light and dark colour. 


\section{The TAwny OR WoOd-Owl. \\ (Syrnium alúco.)}

The Wood Owl, known also as the Brown or Tawny Owl, has the admirable trait of constancy, for it is said he mates for life and the pair return year after year to the same tree to nest. In the month of September you will hear him hooting in the woods more than at any other time of the year. He is not so constant in his choice of locality, but like many other birds he and his kind will disappear from a district without any apparent reason, to return to it again after a time. No doubt they follow their food supply; the small creatures they feed onmice, rats, shrews, and squirrels -all disappear in the same fashion to re-appear elsewhere; the movements of these being no doubt ruled by the same conditions of suitable food, its scarcity or its plenty.

In spite of persecution the Tawny Owl is still fairly common in our own country wherever there are woods or crags suitable for its habitat. In the South of Scotland it is common, as well as in England and Wales. It is strange that it seems to be absent from Ireland. Here, in Ealing, where the present writer lives, its whoo-hoo, or, as Shakespeare has it, tu-whit and to-who, are heard regularly in one little spinney at the south-east corner of our suburb; and last summer-igo8-a pair took up their abode in a garden, right in amongst the shady roads not very far from the Broadway.

The Tawny Owl breeds early; strong-flying young ones may be seen in April. A hollow oak tree or an $\mathrm{elm}$ is a favorite nesting site with it. The young are 
USEFUL.

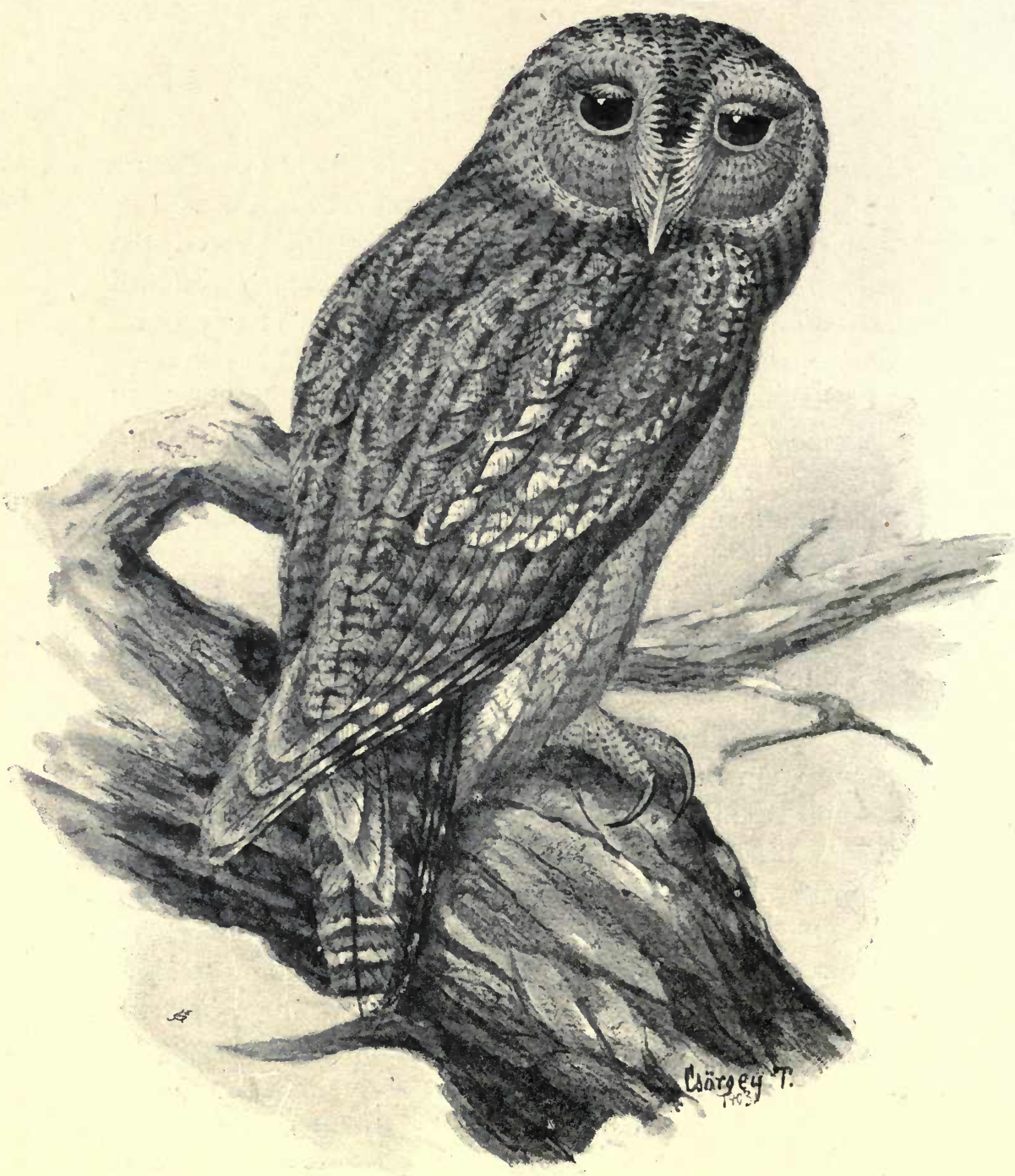

THE WOOD OR TAWNY OWL. 
very easy to rear and to tame. The late Lord Lilford, who was perhaps our best authority on owls, stated that he had examined many pellets of the Tawny Owl, and although he more than once found the remains of young rabbits he could not accuse the bird of any serious poaching.

Living more in the woods the Brown Owl is less often observed than is the White Owl; also its plumage is darker, and this makes it often less visible, especially in the shade of the trees. When flying, his legs are stretched out behind, "as a balance to his heavy head," White of Selborne remarked. The young ones, funny little balls of grey down, resemble, some one has said, "a pair of Shetland worsted stockings rolled up, such as might have belonged to Tam o' Shanter."

And this reminds us of Burns, who, when he bids the birds mourn for him, "Wha lies in clay, Wham we deplore," sings :

"Ye howlets, frae your ivy bow'r, In some old tree or eldritch tow'r,

What time the moon wi silent glow'r,

Sets up her horn.

Wail through the dreary midnight hour

Till waukrife morn."

But Shakespeare said of the Wood-Owl:

“Tu-whit! tu-whoo, a merry note While greasy Joan doth keel the pot!",

It was in 2 Io pellets of this species that Dr. Altum found the remains of 6 rats, 42 mice, 296 voles, 33 shrews, 48 moles, I 8 birds, and 48 beetles, besides countless numbers of cockchafers. 
Brown Owls make very amusing pets and they are not hard to tame. They are less suspicious than other owls and become very companionable. R. Bosworth Smith, whose recent death was so much lamented by all bird-lovers, and who said: " Birds have been to me the solace, the recreation and the passion of a life-time," told of one young brown owl which he brought up from the nest, which was very fond of music. It would make its way, through an open window on the ground floor, into the room in which a piano was being played and would even press closely against the case of the instrument. Dr. J. Cooper, Professor of Greek Language and Literature at Rutger's College, New Brunswick, also told the same author that one morning in November of 1899 he found, on going to his lecture room, that a brown owl had somehow made its way into it, and had selected as a perch a huge framed photograph of Athens. It was, he remarks, an unlooked for illustration to both teacher and taught, of the proverbial expression "Owls to Athens." And there she was, just over the Areopagus, the High Court of Athens, and she sat perched there four whole hours, that "bird of wisdom," whilst the Professor gave as many lectures to successive classes of his pupils, quite undisturbed by the noise they made, coming and going. Before she disappeared, one of the lecturer's brother-Professors had time to take a photograph of "the Bird of Pallas on her chosen throne."

Description : In the adult male the upper parts are of variable shades of ash-grey, mottled with brown; there are large white spots on the outer webs of the wingcaverts; the tail is barred with brown and tipped with white; the under-parts are a buffish-white, mottled with 
pale and streaked with dark brown. The disk about the face is greyish, having a dark brown border; the legs are feathered to the claws. The length of the bird is about 16 inches. The female is larger than the male and its plumage is a more rufous brown; but there are two varieties in this species, a red and a grey, the colour being independent of sex; the rufous form is more common in Great Britain. After the first greyish down of the nestlings they put on a more reddish brown than the adult birds have. 


\section{USEFUL.}

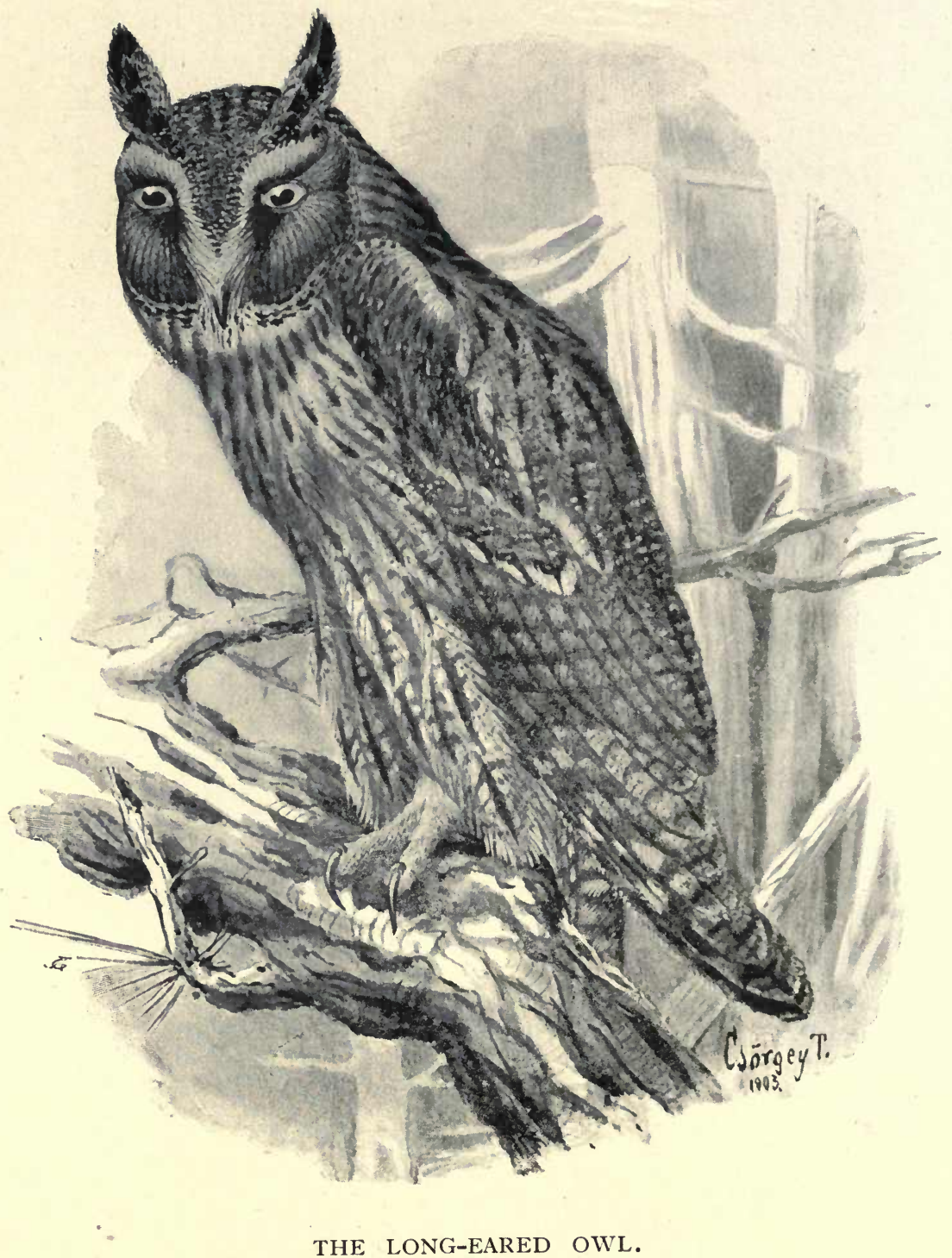


The Long-eared Owl.

(Asio ótus.)

In the wooded districts of Great Britain this handsome Owl is always to be found; the numbers bred here are augmented also by a considerable number which come to us in autumn from the Continent. It is a larger bird than the Short-eared species and it lives much in the same way as the Brown Owl. These two are not so fastidious in their way of feeding as the White Owl. It lives on small birds, rodents, bats, fish, reptiles and large insects. Some have accused it of taking birds up to the size of a Plover, but the late Lord Lilford stated that he had never heard any complaint of its destruction of game in those districts where it was comparatively common; the castings of this species which he examined were mainly composed of the remains of greenfinches, sparrows and field mice. It is often seen flying about by daylight and it has been known to pick up and carry off wounded birds. It is said to be much disliked by other birds-possibly the last mentioned habit may be at the bottom of this strong feeling on their part, also its appropriation of other birds' nests. The note of the hungry young birds of this species is a lou mewing.

The prophet Isaiah had not very pleasant associations with Owls, it would seem. When speaking of desolated places, he says, "Owls shall dwell there, and satyrs shall dance there ... the screech owl also shall rest there ... the great owl make her nest . . ."

Alluding to the death of Julius Cæsar-or rather to the omens that preceded it-Shakespeare wrote: 
"And yesterday the bird of night did sit Even at noonday, in the market-place, Hooting and shrieking.'”

Of crook-backed Richard of Gloucester, too, he says :

"The Owl shrieked at thy birth, an evil sign, The night-crow cried."

Different parts of the White Owl's body were supposed to possess different magical powers, and they have been used by many a rural imposter to breed awe in the credulous.

Happily all this is changed now excepting amongst a small ignorant minority. Of late years women who affected the fashion of wearing owls heads and wings on toques seemed likely to become the poor Owls' worst enemy. Mr. Ward Fowler saw, not long ago, in a public house, this advertisement: "Wanted at once by a London firm, I, ooo owls."

The late R. Bosworth Smith wrote: "The number of owls has been terribly diminished. Let them be encouraged and protected in every possible way. Let the gamekeeper be rewarded, as I have rewarded him myself, not for the owls he destroys, but for the owls he preserves. . . . Let the owl be regarded and protected in England as the stork is regarded and protected in Holland !"

The Long-eared Owl is $\mathrm{I}_{5}$ inches in length. The upper parts are a warm buff, mottled and pearled with brown and grey and streaked with dark brown, bill black, dark markings about the eyes, facial disk buff with greyish black margin and outer rim. The long erectile tufts are streaked with dark brown. The eyes 
are a rich yellow. Under parts warm buff and grey with broad blackish streaks and small transverse bars. Legs covered to the toes with fawn coloured feathers. The eggs, four to six in number, are laid with us in an old squirrel's drey or on the old nest of a Ringdove, a Magpie, Rook, Crow, or Heron's nest; in Hungary often in that of a Buzzard or a Kite, with a few slight sticks and rabbits' fur added. They are white, the surface smooth but not glossy. As a rule this species does not hoot like the Tawny Owl, but is rather silent. 
USEFUL.

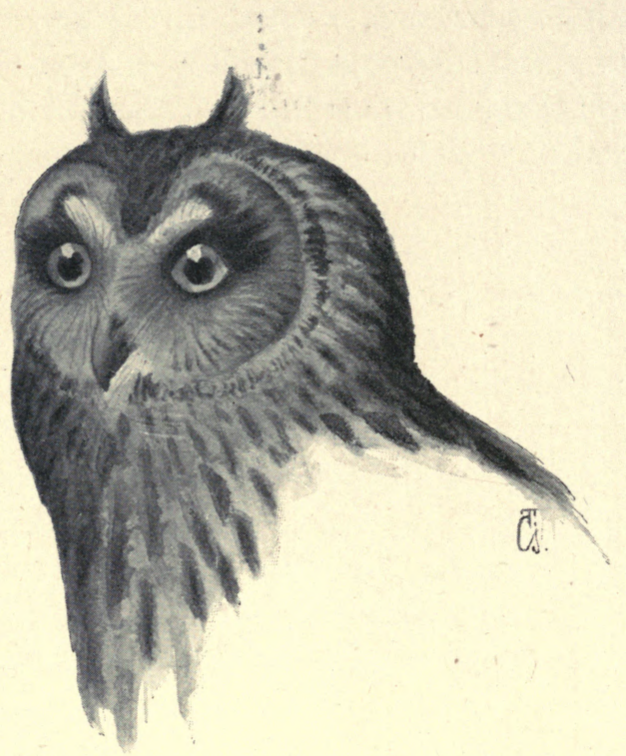

THE SHORT-EARED OWL. 


\section{The Short-eared Owl. \\ (Asio accipitrinus.)}

In Hungary Short-eared Owls appear in numbers with the Buzzards where field mice get the upper hand, and work with these grander birds. A peculiarity of the species is to crouch down to the earth like a hen when in danger. So confiding in nature is it that it falls an easy prey to the guns of those whom we call the "Sunday sportsmen," to the great loss of the agriculturist. Large numbers of the Short-eared Owl arrive regularly in Great Britain from the Continent, to remain with us during the winter. This species is often termed the Woodcock Owl here, partly on account of its twisting flight it is supposed, and also because both birds make their appearance about the same time-some years in larger, some years in lesser numbers. A few pairs still breed in the eastern counties, but it nests more often in the north, in widely scattered parts of our moorland districts. In Scotland the species is common; but in Ireland it has not yet been recorded as breeding, although it is very common there in winter. I remember a relative telling me of a Short-eared Owl hovering much over a terrier he had out walking with him, one evening late, on Congleton Edge. Probably the bird had its young on some tuft of heather near them and was anxious as to the safety of these, and it would not have hesitated to attack the terrier had it been alone.

Mr. Ogilvie-Grant, in Lyddeker's " $R$. Natural History," says: "It is a curious circumstance that, 
although the number of eggs laid by this bird (the Shorteared Owl) is generally four, yet, when food is unusually abundant, as during a lemming-migration, the number in a clutch will rise to seven or eight, and during the recent vole plague in Scotland larger numbers were recorded, reaching as many as thirteen."

As many as ten and twelve eggs were often found on some hill farms where these Owls remained feeding all the winter and commenced nesting in March, the birds in many cases nearing a second brood.

Mr. Colles, of Higher Broughton, Manchester, speaking of the Short-eared Owl, said in a letter to his friend (R. Bosworth Smith): "You will remember that a few years ago certain parts of the country (Scotland) were infested with voles to such an extent that the sheep would not eat grass over thousands of acres of moorland. It was some two years after they had been at their worst that my son and I were fishing in St. Mary's Loch; and one day, about noon, while I was crouching down between the high banks of the Meggett, to keep out of sight of the fish, a Short-eared Owl skimmed over the top of the bank directly to the place where I was; and I can assure you that no exaggerated comic picture of an Owl I had ever seen affected me as did this one. Its eyes looked to me as large as saucers, and the bird seemed a perfect ogre. A few days later we were fishing one of the tributaries of the Tweed near its source; and had to walk a mile or so, on almost flat moorland, where there was hardly a bush, much less a tree, to be seen. Wherever there was rise enough in the ground to form a little bank the soil-was perfectly honeycombed with what appeared miniature colonnades or rather cloisters, and we caught 
frequent glimpses of the voles within, as they flitted along their galleries. When we were well into this dreary place a couple of Short-eared Owls positively mobbed us, and as we walked along, with our fishing-rods over our shoulders they followed us till we reached a dry gully, where they became even more demonstrative, coming well within point of our rods. On both occasions the hour was between eleven and twelve o'clock and the sun was shining brilliantly."

The Short-eared Owl is fierce and bold in defence of her young. She will attack larger animals than herself. In the Hawaiian Islands she has always been much admired because of her fine qualities, and was indeed one of the old tutelary deities of the natives.

This Owl is from 14 to 15 inches in length. The ear-feathers are short, the irides yellow, bill black, black about the eyes, and the facial disk is browner than in the last-named species; the plumage of the upper parts is more blotched than streaked; the buff tint is more decided. The ear-tufts, though erectile, are short, and not seen except when the bird is excited. Underparts streaked lengthwise with blackish-brown, but have no transverse bars. The young are browner and darker and more boldly marked, and tawny on the under parts, iris paler than in the adult. 
USEFUL.

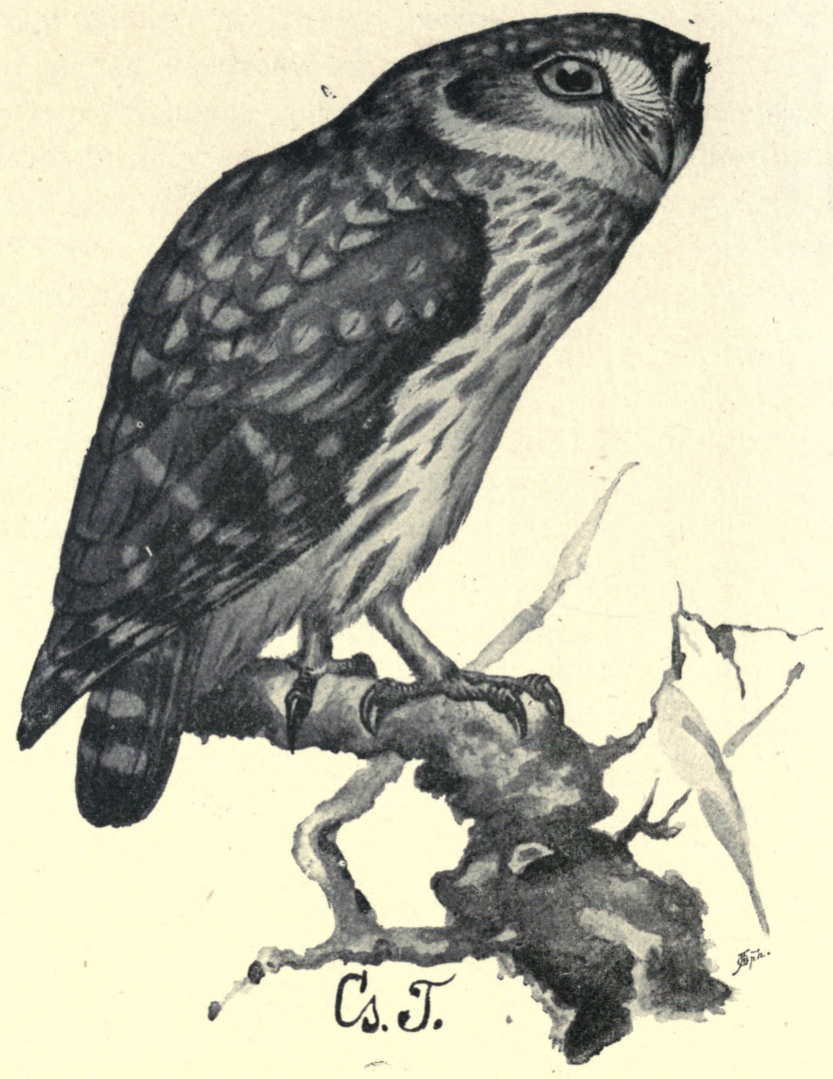

THE LITTLE OWL. 


\section{The Little Owl.}

\section{(Athéne noctua.)}

The Little Owl makes its nest where it has its ordinary dwelling-place; that is to say, in hollows, behind beams, sometimes even under bridges. The clutch of eggs is four to five, and they are almost perfectly round. The young are covered with white down.

This is a friendly little species; it likes to get under the house-roof, into barns and towers; retires also into the hollow of a tree and clefts in old masonry. A capital mouse-hunter, it feeds also largely on insects, and haunts the lawns to get out the earthworms. In winter it catches birds at roost, getting numbers of Thrushes, also mice and other small mammals. When the chase is prolonged till daylight the small birds mob the Little Owl, surrounding him in numbers. They dare not meddle with him because of his sharp claws, but they scold and chatter at him as a shameless thief. Bird-catchers profit by this, and they fasten him to a bough to act as a lure. There is in Hungary a superstition that no one dies where this Little Owl appears and utters his cry of Kooweek, kooweek! which comes down from the gables or the attic windows of the house.

The numbers of the Little Owl have been increasing in England of late. Mr. Meade-Waldo informed me that in the neighbourhood of Penshurst, near his own home, in Kent, he had seen as many as sixteen Little Owls perched on the telegraph wires on the line between two 
stations. This gentleman has always been known to be a lover and a protector of this species:

In Leadenhall Market there are often cages full of them which have been brought over from Holland. They make delightful house pets and good mousers indoors. " I have one of my own," says A Son of the Marshes, " and I set him down as a bird of priceless value, for he has the power to make me laugh when I should be least in the mood for it ... Jan Steen and Teniers introduced him into their pictures. In that of 'The Jealous Wife,' for instance, there is the Little Owl perched on the window shutter contemplating an aged man holding sweet converse with a young woman, presumably his niece. The old woman, his wife, has also her head in the opening, taking in the scene wrathfully. My own bird is at liberty. This he uses to the best of his ability, making the third member of our small household."

The Little Owl is about eight inches long, but seems bigger than it is because of its large head and soft plumage: its body is compressed in form. Bill and iris are yellow, legs clad with hair-like feathers, toes almost bare. The short tail is hardly visible beneath the points of the wings. The back is greyish-brown, spotted with white; the belly whitish, with long brown markings. 


\section{THE Rook. \\ (Corvus frúgilegus.)}

The Rook lives in flocks and breeds in great colonies. Its nest is smaller and looser than that of the Hooded Crow. Five or six nests one above another, are often found in one tree-sometimes as many as eighteen. It pairs somewhat late, in Hungary, but already in April may be found three to five eggs of a pale green colour spotted with grey and blue. These are smaller than those of the Hooded Crow.

The Rook spends the greater part of its life in its native home, often in huge crowds, numbering many thousands, which divide up during the day to seek fond in different parts of the neighbourhood. During the breeding time they are divided according to the breeding places. This bird is the most zealous follower of the ploughman, and by its great number destroys an enormous quantity of noxious creatures-the cockchafer being its most coveted delicacy. It covers, with its flocks, the freshly ploughed field, and if they are sown, picks up the grains that are lying about. It bores into the soft earth of the meadows and cornfields, for destructive grubs, and pulls up the withered plants in order to secure the caterpillar or wireworm which has destroyed the roots. This has caused the Rook to be suspected of plundering the fields, but the question has not yet been settled, and the general inclination is in the bird's favour. The fact is that even in Hungary, where the Rook exists in millions, the people generally are indifferent about it. Early sowing, while there is suff- 
CHIEFLY USEFUL.

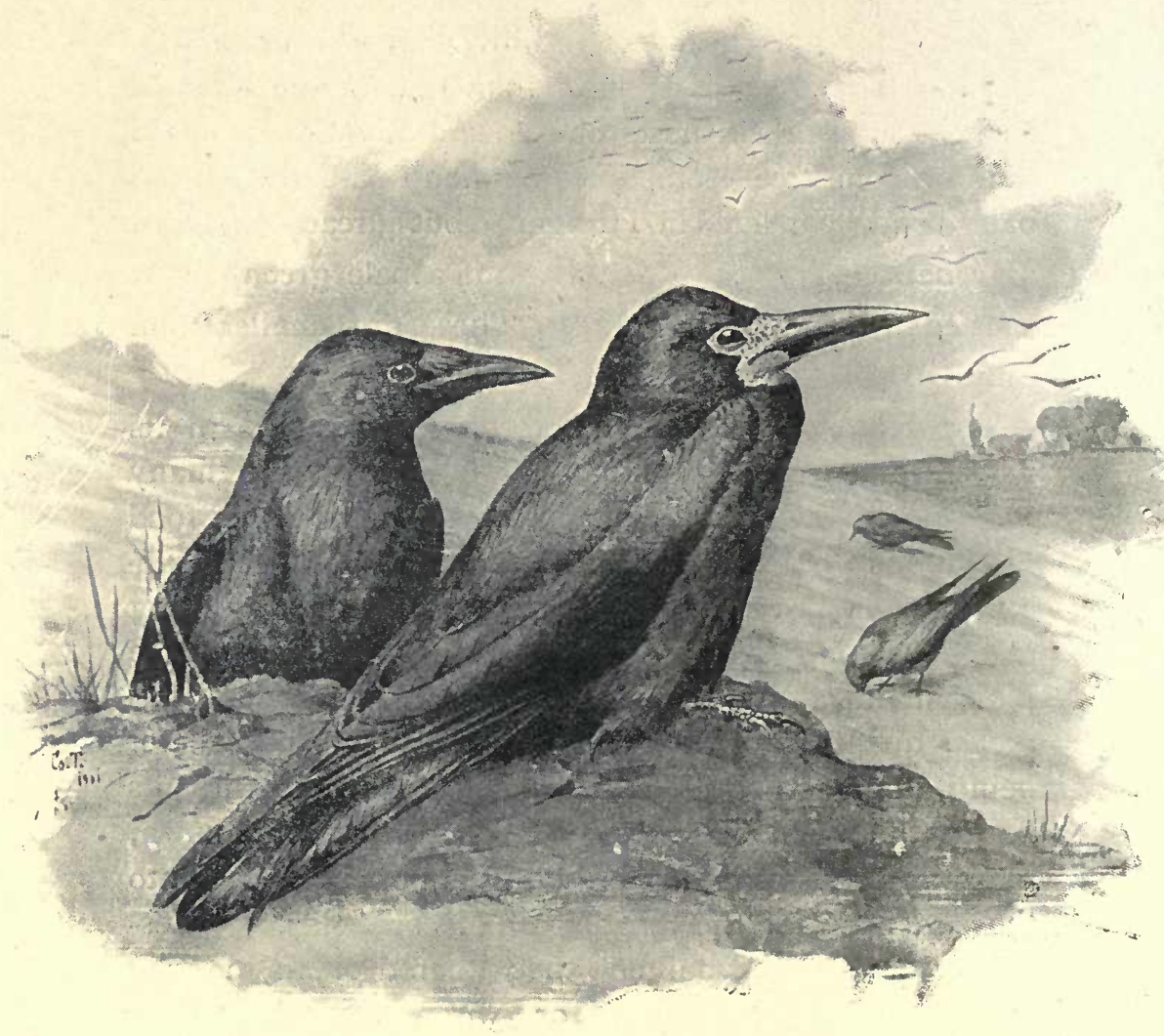

THE ROOK. AN OLD AND A YOUNG BIRD. 
cient insect food for the birds, is the best protection from its mischief, and this is good for the services it performs.

A knowledge of the habits of the Rook is important, because the bird is closely associated with husbandry, and with its well organised work deeply affects the interests of the husbandman. While the Hooded Crow roams about the district with the Jackdaw, thousands of Rooks cover the corn-fields; they settle also on fallow ground, on the freshly ploughed field, on the sprouting crops, and on the turnip-field. It is this appearance in vast numbers which mainly distinguishes the Rook from the Hooded Crow, which otherwise its habits closely resemble.

In regard to this bird also, different views are held. Whilst the scientific agriculturist considers it useful, the old-fashioned husbandman is convinced that it is harmful. Here again, therefore, must a just verdict be given, between two opposing parties-but this verdict must be impartial. Various things are said of the Rook-but it is not true that it picks the seed out of the earth, so that the spoiled seed has to be ploughed in again. It only takes the seed which has been imperfectly covered by the harrow, - and the reploughing is only an empty complaint, for no one ever heard tell of a particular village, or farm, where reploughing had to be performed on account of the Rooks. The farmer who keeps his eyes open before he gives an opinion knows that the Rook digs his beak into the ground because he hopes to find worms there. Sometimes it is shot, in order to be set up as a scarecrow, but they say nothing of what may be found in its crop, should it be opened; this, however, is just what is necessary in order to ascertain 
the truth-although the other conditions of its life must also be taken into account.

It is easy to observe the behaviour of Rooks, because they always move and act in flocks. These flocks are dissolved only in cold snowy winters, when the birds, tired of the cold and lack of food, come into the villages. When the early spring ploughing begins, part of them follow the plough; the flock spreads itself over the freshly ploughed land and they snap up the grubs of the destructive insects which escape from the newly-turned clods. This then is useful work. They also settle on the sown land and pick up the seeds which the harrow has left on the surface, but at the same time devour the insects which the harrow has turned up. There is no harm in this. In a short time the full spring has come and the immature insects have developed into other forms - then the Rook begins to think of building its nest. Its young are not fed on seeds, for at that time there are none to be had, but exclusively on insects-which again is a great and useful work. Then the flock spreads over the neighbourhood, leaving their sleeping-place in the morning in a body, and betaking themselves to different parts of the district; and it may be remembered that separate flocks repeatedly visit the same spot, and work there; as, for instance, one point in a great stretch of cornland, where in the track of the birds lie many uprooted plants, which the farmer generally looks upon as due to the mischief of the Rooks. When insect life has become stronger, they settle on the meadows, where they eagerly hunt for crickets and grasshoppers; then they return to the ploughed fields and destroy the insects that have been disturbed-and this is useful work. It is true that later on they visit any heaps of cut corn 
that may lie in their way, and in this way do harm, but the greater number of the flock pick up the fallen grains in the stubble field, and a few follow the carts which carry the corn, and pick up any that is dropped. There is no harm in this, as these ears would in any case be lost to the farmer. At the time of the hay harvest they settle on the ridges of cut grass and hunt for crickets and grasshoppers, for these creatures have then no cover, and easily fall a prey to the birds. The Rook also attacks the young maize and fruit, but it has not skill in this respect and cannot do much harm. The harm done is outweighed a thousandfold by the good which it does in the destruction of insects. The black army of birds lights also upon the turnip crops just at the time when these valuable plants are covered with masses of the "turnip caterpillar." By the destruction of this pest they do the farmer invaluable service.

This sanitary work continues into the late autumn as long as the caterpillars, the Rook's favourite food, remain. The Rook may do serious damage during the autumn sowing, especially if it is thin, and sown and harrowed so late that the caterpillars have disappeared, not so much, however, that the field must be ploughed up; at the worst there would remain only one or two unproductive spots, and we know that corn grows in tufts, and if it is not thinned by the Rooks it must be done by the farmer, so that the corn is not choked by its own abundance.

When the hard part of winter comes, the flocks of Rooks seek towns and villages, where they spend the nights on the roofs of houses in order to shelter themselves from the icy wind; during the day they steal from 
the barns and granaries, or, if the opportunity offers, they get at the bundles of straw which they pull about to try and find a stray ear of corn.

This much is certain that the principal food of the Rook consists of insects and grubs, which it gets not only from the surface of the earth, but also from beneath it, when the bird sees from the colour of the fading plant that a grub is gnawing at its root. This is the meaning of the uprooted plants; and why one flock after another so often visits the same cornfields. It is a sure sign that the wireworm or some similar pest is busy with its depredations. Here again the work of the Rook is a blessing.

There are neighbourhoods where the farmer makes. a great fuss about a grain or two of wheat or maize, as if he must be ruined by the damage. I repeat that the bird has earned its few grains by its other work; indeed, without its useful services these grains would probably never have grown.

The lesson we learn then is as follows :- The Rook lives principally and preferably on insects, grubs and worms, and so long as these are procurable, it does not look for grain - therefore, the spring sowing should be performed as late as possible, when the insects have developed, and the Rook can find its natural food; in autumn the sowing should be done as early as possible while there are still some insects to be found. The further actions of this bird are protective, for it attacks the gnawing maggots that live in the ground. These facts can be verified by dissection of the bird, when the stomach is often found to be full of wire-worms.

None the less researches into the habits of the rook 
require to be more thoroughly worked out, and this must not be lost sight of.

I asked a tenant farmer in our own Midlands his views on the subject of Rooks and the following, with some slight editing of my own, was what he sent me. I give it in full as although there may be some repetition of the foregoing statements, it has special interest as coming from one of our English farmers.

A recent writer from the sportsman's point of view speaks of the Rook as " this black robber," and he says that there is no practical difference of opinion as to the question whether his benefits outweigh his depredations. Now, as a farmer, I confidently affirm that he does much more good than harm. He will sometimes uproot vegetables in getting at the worms round their roots. It is true also that he often robs the nests of the pheasant and the partridge; but, as I could easily show, he does far more good to the general community by furthering the labours of agriculturists, on whom so much depends, than harm to the sport of our leisured classes.

A more social bird even than the gregarious starling, he flies in flocks, feeds in flocks, and builds in flocks. His everyday life may appear to be an uneventful one to the outside world, and most commonplace; yet it is full of adventure and of joy tempered with sorrows. Apparently a grave bird, he is brimful of humour and, at times, as full of play as a titmouse. Like all other links in the seemingly endless chain of nature, he is the victim of circumstances: without much ado he could count up his sincere friends, but his enemies are beyond his conception of numbers.

From his winter homing quarters he comes with his 
company during February to inspect the colony of breeding nests which he regards as his peculiar domain, going back as night approaches to his sleeping-place until all is ready for the family life to begin. Rookeries vary, of course, greatly in size; one may be as a city or large town, again there will be a village, and here and there a small hamlet. There are in my own fields one of about a hundred and thirty nests, one of sixty, one of eight, and another of four nests. Of these latter I have some views of my own. I believe them to be those of odd and outlawed individuals who follow the other companies hither, but are socially considered as pariahs. My nearest neighbours are those of the sixty-two-nest village, and my last census-taking records about sixty-two married couples and thirty-six or more odd or unmated birds. These are all, of course, adult birds, their numbers reckoned before the young were hatched out.

The odd birds may some of them be outlaws, as I said before, but the majority of them are not vagabonds by any means. They only happen to belong to that numerous enough class amongst humans-those who have been forced by some just cause or impediment into a life of celibacy. As the rook does not mate until it is nearly two years old, a number of the single birds are, therefore, simply lusty young bachelors. The few individuals whom I sum up as ne'er-do-weels or unfortunates-I know personally three of these at the present moment-are to be recognised by the shabby, neglected, and generally unkempt appearance of their plumage, and some other of the many outward signs of a past henpecked existence. I am ignorant of the life history of these; perhaps if we knew all about them we should look upon them as objects of pity rather than of reproach. 
Now and again I notice that a few old birds in our colony appear to be dissatisfied with everybody and everything; and imaginary grievances, political and social, often lead to a segregation scheme. This is how I have accounted for my hamlet of four nests. The general run of our odd, or celibate, birds is, however, good in character; they help in the building of the nests and even in feeding the sitting birds. For the wedded pairs April is a most trying time : if the season be a dry one, or frost sets in, food is scarce. Insects and worms are deep in the earth; the farmer is engaged in sowing his spring corn, oats, and barley. The rooks prefer a diet of insects, worms and grubs, but these are hard to get at times; the spring beans are just peeping through, and the sitting hen asks for food. The cock bird ventures too long in the beanfield, and as he skims over the hedge with a bean or two in his pouch a shot is heard; the faithful mate of the sitting bird is brought down to mother earth, and the farmer feels that he has one enemy the less. Personally I would not shoot a bird if you gave me a sovereign for it. The old bird may, and does, grieve, but the news of her loss is soon at the rookery, and her food is brought to her by a new mate. Thus there is a place taken in the rookery by one of our odd birds, and there is a bachelor less in the community. I have known many a bird die about this time through over-zeal-a slave to love and duty. If April prove seasonable and mild with showers, worms are plentiful, and the farmer's gun remains in its place over the kitchen chimneypiece.

Often during the building season the rookery is disturbed by discordant notes, accompanied by a great fluttering of wings; there is a big row in the township; 
not a duel over a "squaw" : the rook is a philosopher, and the ritual of love-making and matrimony are of the simplest. The bother will be over divergent interests or a disputed claim, for there is a recognised right of property-not ground-rent to pay, but a specified limit for nest-room has been accorded. The trouble occurs mostly with young birds wishing to place their nests too near to an old nest. A parish council is called, with the result that the disputants' nests are soon scattered to the winds, and the claimant and the defendant may both have to begin a new foundation. Sometimes there is a disturbance on a more limited scale: one between very near neighbours or blood-relations - a family jar, in fact. One pair of birds do their very best to pull the sticks from the nest of another pair : each of the contending parties will do all they can to prevent the other from building.

As to the nests, we all know how busily the rooks set to work to repair these after a gale of wind has wrought some havoc in their colonies; but I do not think it is equally well known that they are curiously weather-wise, and they scent the coming storm and set to work to repair and strengthen before the imminent gale has been evident to the farmer. I have noticed that fact; the Rook's powers of sight and hearing are remarkable.

At the end of the breeding-season comes the farmers' rook-shooting, which I, for one, never take part in : I have too much regard for the labours of both the adult and the young birds. About the roots of each of the turnip-plants there may gather scores of wireworms, which eat the turnips; in the crops of young birds which have been shot are found myriads of these wireworms, or it may be that they are filled with grubs of various 
sorts, the larvæ of cockchafers, etc. In fact, in my opinion-that of a tenant farmer who is forced to make things pay - all the Rook's acts of depredation ought to be forgotten if we carefully consider the great services he renders to the agriculturist. Beetles, tipula (Daddy Longlegs grubs), warble grubs, oak-leaf roller caterpillars, and the caterpillars of the diamond-backed moth he devours. The game-preserver may grudge the birds their plundering of his nests, but the farmer is in gratitude bound to spare them. A lot of young birds at the rook-shooting time are still unable to take a flight of any distance, but others are, happily for themselves, able to fly well. I am persuaded that the old parent birds often -foreseeing a shooting raid-get these out of the way, and so they secure life for a number of their young who might have been sacrificed. They betake themselves in parties to their rootings about the elms upon outlying pastures. Daily they grow stronger on the wing, and learn the ways and means of living.

Like all long-lived creatures, the Rook is temperate in eating, and he is cappable of going a long time without food-a faculty which stands him in good stead during hard winters. In a long frost or a prolonged drought he is a most determined robber, and when he is on what he knows to be forbidden ground, he posts a sentinel to give warning of the approaching farmer or watcher. $\mathrm{He}$ is known to take the eggs of such favourite birds as the thrush and the blackbird, whose nests are open, and therefore soon discovered and plundered. But this is no doubt where his proper food is scarce; and if man had not been so eager in the destruction of some of our birds of prey, who are the natural enemies of him and his, Rooks would be less plentiful in some districts. 
Still, I for one have no desire to see their numbers decrease, so certain am I of their value; and I believe this bird will become even more valuable as time goes on.

The Rook is somewhat smaller than the Hooded Crow ; the beak more slender, rather straighter; the base of it in mature age bare, and covered with a. kind of white scurf. The entire bird is black with a steely-blue and purple gloss. The feet black and thick, the claws strong, the sole rough; it walks better than the Hooded Crow. The beak of the young bird is not bare, the nostrils being covered with bristly feathers. The bareness first appears when the bird begins to dig in the ground for its food.

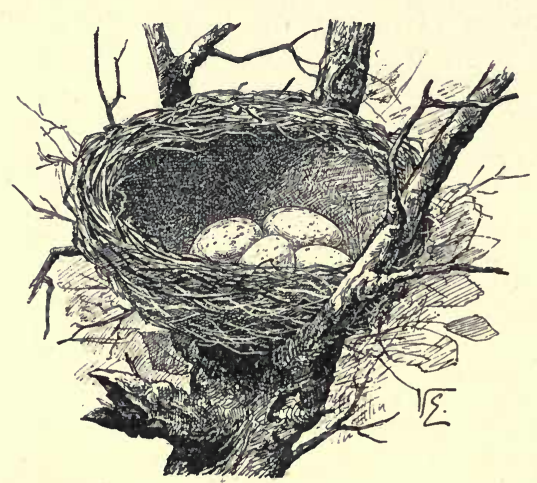

The open nest tempts the Rook. 


\section{The Hooded-Crow.}

\section{(Corvus cornix.)}

The Hooded Crow walks well, with head erect, moving its tail right and left as it goes. Its flight is easy, using comparatively little movement of the wings. This Crow usually makes its nest in the tops of high trees, preferably in one standing alone in a field; but sometimes on rocks. It does not build in colonies but usually settles alone, though occasionally two or three pairs will build on the edge of a wood or in a small plantation. The nest consists of twigs, roots, and grass; the hollow of the nest being safely lined; in the spring it contains four to six eggs of a light green colour speckled with grey and brown marks.

In mild seasons this bird has been known to pair, as early as the end of February, but the usual time is March. Then the construction and arrangements of the nest begins. The female bird, only, sits on the eggs; the male guards the nest and provides the food. When near the nest, he is a courageous, even daring bird, able to keep off such enemies as the Hawk or the Eagle. His cry is "kár, kár."

The Hooded Crow is a clever intelligent bird. It easily adapts itsellf to circumstances; the wave-lashed rock, or the icy peak, are as acceptable to it as green meadows, or the palms and sycamores of Egypt; the woods, as welcome as the heart of the snug village, as the tiny garden round a peasant's hut. It is omnivorous; so long as it can find food in forest or field, on the sea shore or river bank, it avoids the proximity of man; but when winter comes, it settles near inhabited districts and 


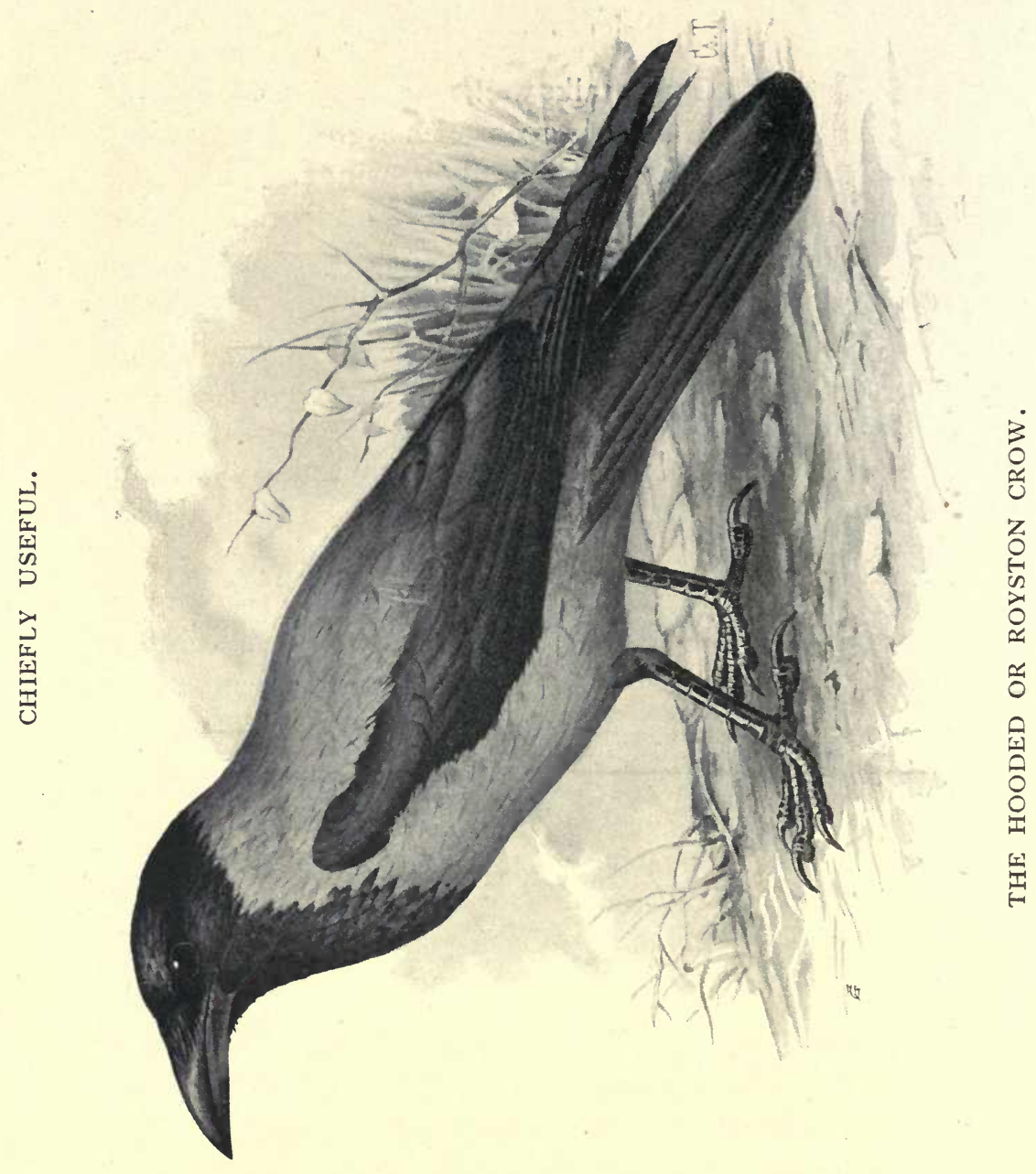


highroads, in order to seize upon anything eatable, however bad its condition.

And now let us investigate its actions, which divide men into two camps, one of which states that the Hooded Crow is harmful, the other that it is serviceable. First, as to the harm. It is true that this bird considers a young chicken a great delicacy, and so, takes one when it has a chance. But this happens very rarely, for the good mother-hen flies at the marauder, and raises a cry that brings out the people of the house to see what is the matter, and the Crow has to beat a retreat, without having secured its prey-or run the risk of having a wing broken by a stone, a rolling-pin, or other missile. Should it succeed in securing a chicken, then indeed it has done harm, but this happens so rarely, that the housekeeper does not make much account of it. It is also true that it attacks the timid little hares in the fields, and if the mother is absent, the young ones are quickly destroyed, and torn to pieces by two or three blows of the strong beak. In this case it is the sportsman who is most annoyed, for the farmer is no friend of the hare, which does great harm in the winter by gnawing the fruit trees. It is a known fact also that the Crow robs the nests of birds which are built on the ground in the fields, when it finds them. This also is harm, but the little birds exhibit wonderful instinct in hiding their nests, so that even the sharp-eyed Crow can rarely find one, especially when we consider that its attention is constantly being diverted from the search by a fat cricket or grasshopper, or a mouse slipping hurriedly by. Neither can it be denied that when the ears of maize are young and soft the Crows opens the husk with its beak and regales itself with the milky juice. This is indeed 
mischievous, but the harm is only local. A few farmers track it down, others do not, for about this time the bird begins to mend his ways. It cannot be denied either that it pecks young fruit of all kinds, and later pulls it off the trees, and if not driven away, considerable damage is done, especially if the orchard lies within a district where Crows abound. It is evident then that the gamekeeper must be allowed a little license, for where game is bred and preserved, especially in such places as Pheasant runs, the Crow may do much damage among the young birds; but why is the gamekeeper there, if not to scare away the feathered thieves with his gun? Once having experienced such a fright the Crow does not often return to the same place.

And now let us consider the bird's good deeds.

The ploughman would be indeed unwise were he to scare away the Crow, that, following in the furrow of the plough, picks out from the freshly turned clods, the worms, grubs, and maggots, which are the farmer's worst enemies; nor do the evicted tenants of overturned mouse-nests escape the strong beak of the bird;--and how busy it is when a plague of mice occurs, as it does in some seasons! Then occurs a wholesale massacre, and if this visitation happens in winter, the snow bears evident traces of the Crow's sanguinary work.

It is also useful among the sheep and cattle, settling on their backs, and destroying the parasites that attack them. The beasts leave it undisturbed knowing that it is doing them good service. Neither must we forget that in villages, near human habitations it does excellent scavengering work. It knows the precise time at which the remnants of food are usually thrown out from the cottage on the rubbish heap, and waits on the roof, till 
the moment arrives when it can pounce on the promising morsels, which it carries away; thus removing what would otherwise soon have become putrid. In winter when pigs are killed, the Crows wait, among the neighbouring trees, for their share.

The only remaining question, then, is, in which part of the year this bird is harmful, and in which serviceable, and how long does each of these periods last. The destructive period is really of short duration, for the chickens soon grow into hens, the leverets become hares, the young birds leave the nests, the maize hardens, and ripe fruit lasts but a little while. That is to say, the destructive period lasts but a few weeks. And what does the Hooded Crow do for the rest of the year? It destroys insect pests, cleanses and purifies, and by its continuous activity, does a service to man, which no other creature could do.

Wherever and whenever this bird does harm it must be driven off, but not destroyed. The hens must be kept from roving, and the orchard must be watched. If it will not be scared away then it must be shot. But when busy in the furrow, the field, or the dunghill, let it be left in peace, for it is doing a beneficent work. Neither nature nor man can do without the Hooded Crow, and for this reason it must be treated indulgently.

The head, wings, tail, feet and throat of this bird are black, but not glossy; the lower breast, under-parts, and back ashen grey; the grey colour of the back forms a kind of mantle,- - hence the name Mantle-or Hooded Crow. The strong curved beak is black, the nostrils covered by bristly feathers; the eyes dark brown; the feet strong and armed with thick scales, the soles rough. 
To England and Wales the Hooded, often called the Grey or Royston Crow, is a regular and in many districts far too numerous a visitor, from October on during the winter. A few birds have remained to breed, and some cases of hybridism with the Carrion Crow occur in the North. In Ireland it has become a perfect scourge. In the Isle of Man it is said to nest each year. On the Scottish Mainland again they are far too many of this species. So greedy is he that Howard Saunders tells of having seen him eagerly devouring the carcase of a recently shot member of the same brood as himself. To some extent hybrids with the Carrion Crow are said to be fertile.

A Son of the Marshes says that the Cob-the Great Black-backed Gull, which is called the Carrion Gull, is a noble and open minded bird compared with the Dun Crow-the Hooded Crow of the foreshores. "His general conduct would lead you to think he was only looking about for amusement, up and down and over the water, just far enough to see if any prey, such as a dead fish or fowl, is washing in. He does not mean the gulls to share the spoil if he can help it. He flaps to the beach and out again just to make sure that it is coming all right, and gorbles to himself a little. This wave must beach it, he thinks; but no, with the receding of the wave the fish-a large dead skate-goes also. The next long roller may have more force in it, so he hopes, with half open wings and throat feathers puffed out, down to the very edge of the watery beach. Perching next on a large stone, with keen eye and outstretched neck, the bird sees it gather, a mile out. On it comes, gathering in force as it begins to crest up, until with a crash it breaks, and Hoody's dead fish is flung high and dry 
almost at his feet. Hardly, however, has he had time to give one or two vicious digs at the now tender skin in order to get at his highly flavoured meat, when from all points of the compass other crows come shooting along like so many hawks to join in the banquet. We could have knocked them over well," concludes our Marshman, " but on no account would we have done so for they were doing their appointed work, that of clearing up the refuse brought in by the tide, honestly and well. "Hoody" is one of the scavengers of the foreshores." 


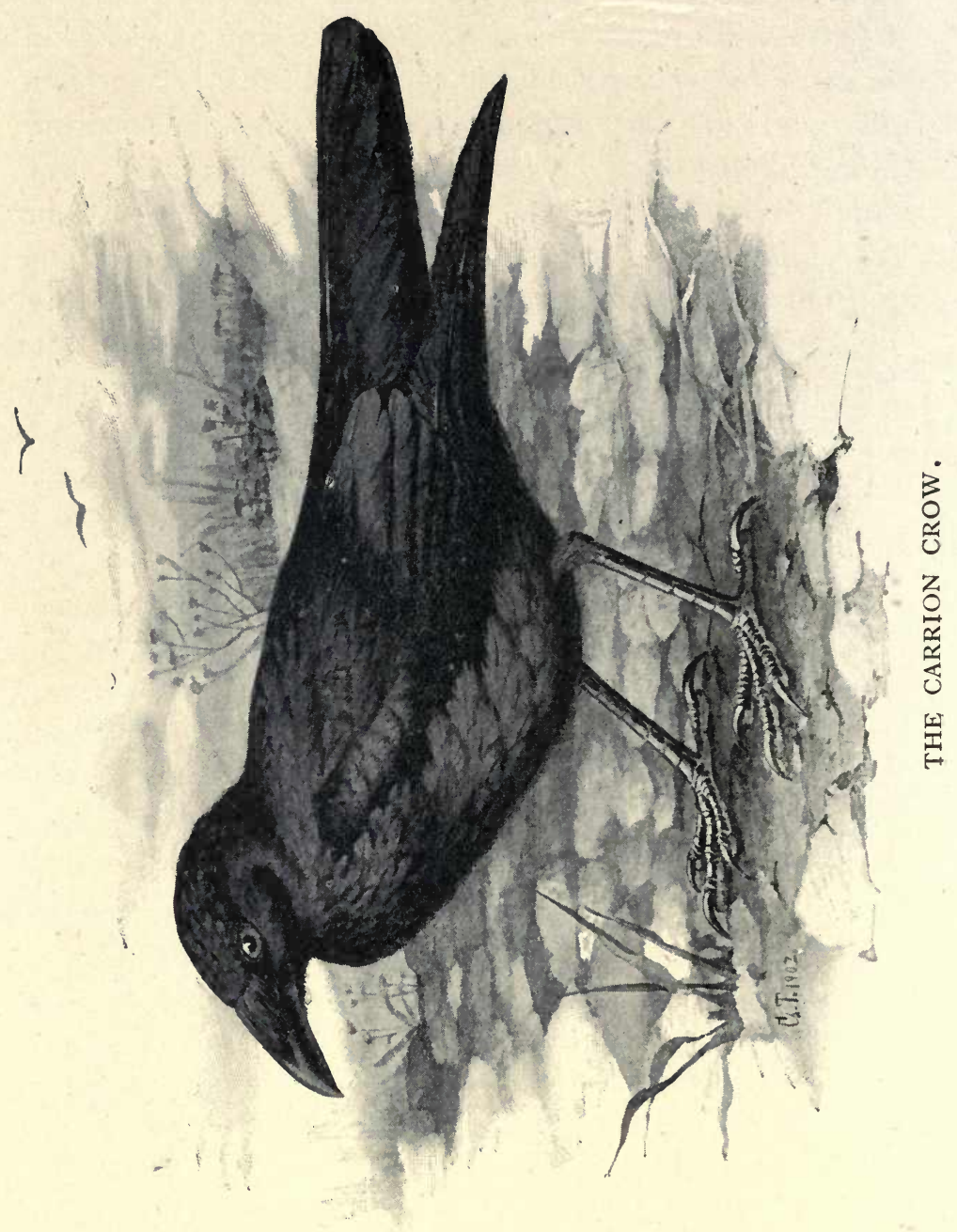




\section{5}

The Carrion Crow (Corvus coróne.)

The principal colour is black, shining, with a steely blue lustre on the neck and back. The beak strong, distinctly curved, and black, as are also the feet; the eyes are dark brown. The Carrion Crow makes its nest in woods and is for the most part solitary; when with others, each one nests alone on a separate tree. The nest consists of twigs, roots, leaves, etc. The hollow of the nest is softly lined, and in the spring, four to six eggs may be found in it, of a pale green colour, speckled with brown and grey.

The Carrion Crow is sly and cunning; courageous, but at the same time, cautious, and extraordinarily clever; it discriminates exactly between the farmer and the hunter, and allows the former to come quite close to him. Its sense of smell is very delicate; it scents carrion a mile away, under snow and earth. This bird is to the West what the Hooded Crow is to the East-from Austria onward through the whole of Germany and in Great Britain. It croaks hoarsely "Caw, caw, caw."

The Carrion Crow follows the plough, and devours grubs and mice; it eats the insects in large quantities, and lies in wait for the mice about their holes. On the sea shore, it will seize a large muscle with its beak, fly up to a considerable height in the air, then drop the muscle on to a rock, so that the shell is broken to pieces, and the contents emptied out. The Carrion Crow steals and plunders the nests of the useful birds, spoils fruit and crops; but the great naturalist Naumann advises that these birds should not be too hastily destroyed, for 
they do mischief only for a short time, while during the rest of the year they make war on the numerous pests, and are of great service to the husbandman.

Since so much bird protection has been inculcated, these Crows are enjoying much more immunity from harm than heretofore. The result is that in some of our London suburbs the bold but handsome creature comes to feed with the small birds at our very doors in cold weather. I have often watched the ungainly yet cautious manœuvres of a Crow which has frequented my little lawn at Ealing. The letting of his heavy body down from over the ends of the outstretching bough of a great elm, which has its trunk on the other side of my fence,. so as to quietly drop on to the grass on the feeding side of the fence-is very comical. He evidently wishes to do it as slyly and as quietly as possible. Caution and cunning are inherited traits with the once persecuted crow. I confess to a liking for him, but then I am not interested in the preservation of game. He pairs for life too, and is therefore a respectable character so far. And he too is useful as a scavenger, and takes also plenty of rats as well as insects and grubs. When the pair are on the hunt together, one watches whilst the other feeds. He greatly resembles his greater relative the Raven, in shape and plumage, and gamekeepers hate him even more than they do the latter bird, which country folks generally regard as the more ill-omened of the two.

Speaking of my own pet Crow, a new maid I had came to my bedside early the morning after her arrival, to inform me that she could not possibly stay in my house 
as a Crow had croaked about her bedroom window "something dreadful."

In Thibet, we read, there is an evil city of Crows, and Hiawatha is said to have known of a land of dead crowmen. The Crow, according to the old Vedas, fell from Paradise, and in Norway there is "the Hill of Bad Spirits," where the souls of the wicked fly about in the guise of crows. Happy the present generation who are taught more toleration for "all things both great and small."

The Carrion Crow has always done good work as a scavenger, for which he has had small thanks. The poets have all combined in holding him up to execration.

"My roost is the creaking gibbet's beam

Where the murderer's bones swing bleaching;

Where the clattering chain rings back again

To the night-wind's desolate screeching."

It is good to believe that "sweetness and light" are gradually getting the upper hand; and the gibbet with its ghastly burden, and most of the cruel superstitions concerning some of the most useful of God's feathered creatures are alike a thing of the past.

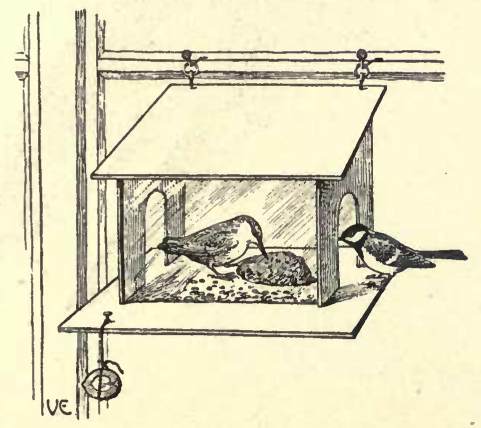




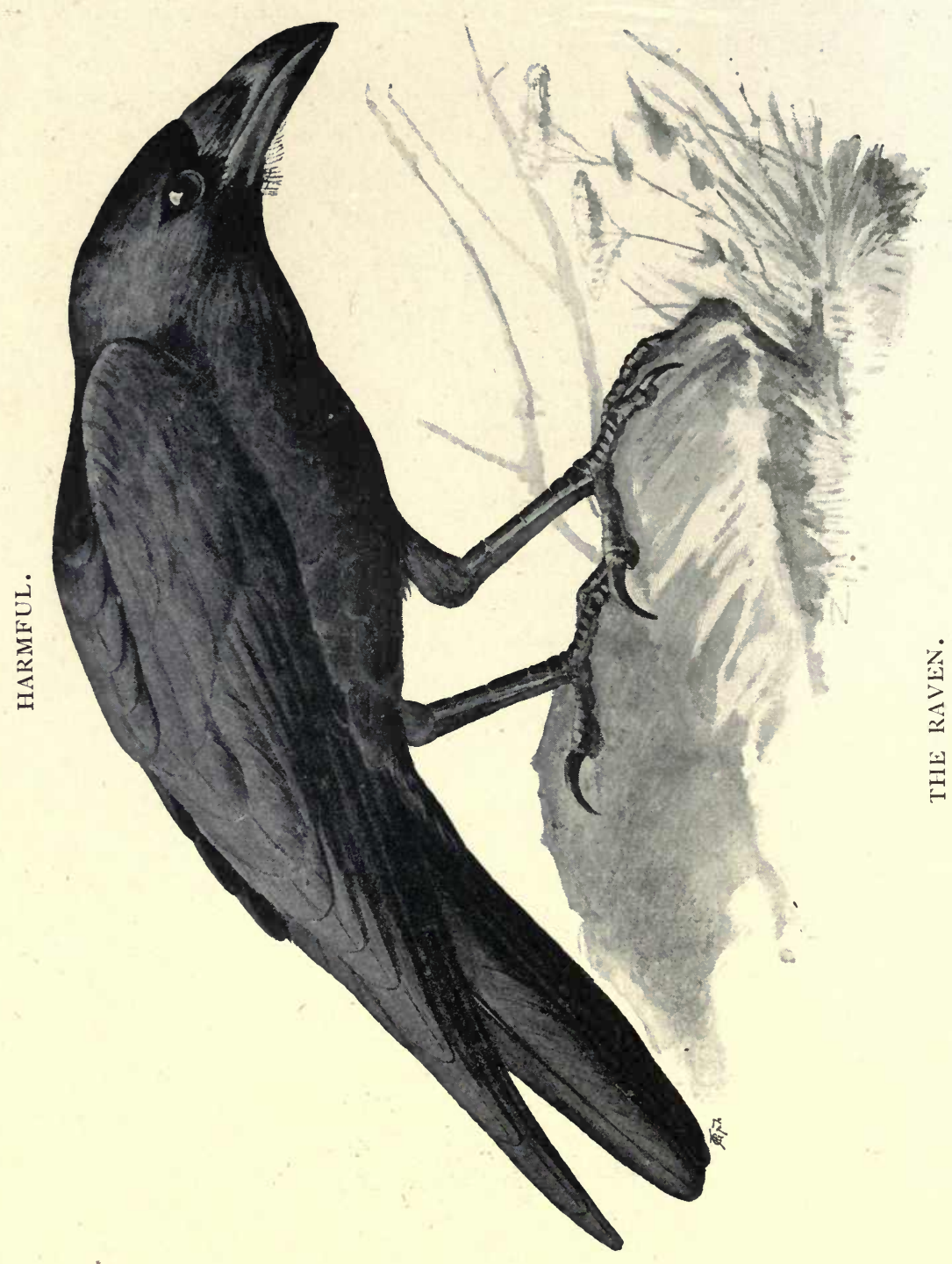




\section{THE RAVEN. \\ (Corvus córax.)}

The Raven is fully one third larger than the crow. Its plumage is black, with a blue or green lustre. Tail wedge-shaped; beak large and slightly curved; the breast feathers pointed. It builds its nest in woods, on the tops of high trees; selecting most cunningly such trees as cannot be climbed. The clutch consists of four to six light green eggs with dark speckles.

It flies well, and can hover in circles, and is a cunning, shy bird, always ready for plunder-but a splendid creature. It is really sad that it should allow itself to be led away to the paths of dishonesty by the sight of shining objects. It attacks everything from earth-worms to hares, plunders and steal nests, takes eggs and fledgelings, and also feeds on carrion. According to popular superstition, it first pecks out the eyes of its prey. The proverb says :-One crow does not peck out the eyes of another.

Another proverb allegorically expresses the fact that the young brood are black :- It may be freely translated as follows :-

"That ravens bear not doves 'tis known, And grapes on thorn-trees ne'er have grown."

The Raven lives to a great age; it becomes tame in confinement, and can be easily taught. It even learns to speak, and can pronounce words clearly. It is the jester among the animals in the farm-yard. It sometimes happens that the black colouring matter is wanting 
in the plumage of the raven, and the bird is then white. This, however, occurs very rarely-so that when people wish to explain that a certain thing is quite exceptional, they speak of it as a white raven.

The coat-of-arms of the renowned Hungarian King Matthias Corvinus, bears a raven with a golden ring in its beak. There were more Ravens in those old troublous days, of long, wild trains of warriors and robbers, when slaughtered men and fallen cattle remained unburied by the wayside, and when the gallows stood in the open field, as a sign and a warning to men,- than there are now, in our days of milder methods.

The Raven is not altogether common with us.

Don Quixote says that King Arthur did not die but was changed by witchcraft into a raven, and that some day he will put on his own shape again and claim his old rights. And so no Englishman - he says-has ever been known to kill a raven, for fear he should kill King Arthur. The Raven, it seems, has continued to build every year since I 856 either at Badbury Rings-Mount Badon, where King Arthur defeated the West Saxons, or else, so the late Mr. Bosworth Smith told us, " in the adjoining park of Kingston Lacy, where they are safe under the protection of Mr. Ralph Bankes."

The necromancers of old are said to detect sixty-five intonations of the Raven's voice; he certainly croaks and barks and chuckles, but it has some pleasanter, more musical notes early in the year in the courting season, and the great solemn looking bird becomes quite playful and even graceful in his movements when his mate and he are about to make their nest. He performs evolutions in the air and turns somersaults most glee- 
fully. The pair play together and tumble down as if shot, and turn over on their backs. Then whilst his mate is sitting he keeps careful watch over her and utters savage croaks if any footstep approaches. He will fight any large bird of prey that dares to approach his nesting place. A faithful creature, he pairs for life and, says one of his lovers "you will hear him utter a low gurgling note of conjugal endearment which will sometimes lure his mate from her charge; and then after a little coze and talk together, you will see him, unlike many husbands, relieve her for the time of her responsibilities, and take his own turn on the nest."

The Raven is in danger of extinction in our country unless better protection can be procured for him. Sheep farmers have a special grudge against him. Its numbers are kept down in the South of England by the prices paid for the young birds. - Still they continue to breed all along the south coast and from North Devon to Wales, wherever there is a suitable headland. The so-called Raven-trees are much fewer than they used to be. The Raven is rare in the eastern counties and in the Midlands. In Scotland it is not uncommon wherever it finds suitable cliffs to build in. In Ireland its numbers are fast decreasing. Its fondness for weakly ewes, lambs and game make him an object of hatred in many districts. 
USEFUL.

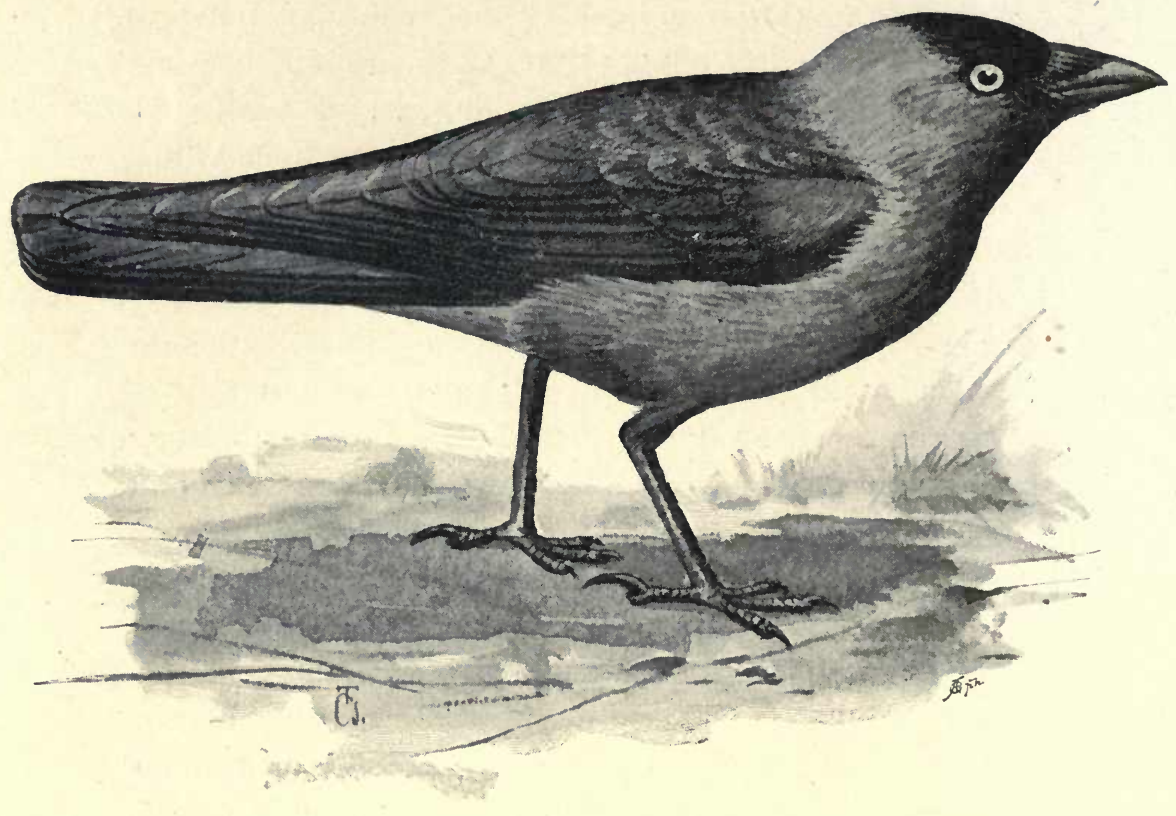

THE JACKDAW. 


\section{THE JACKDAW.}

\section{(Corvus monedula.)}

The Jackdaw is considerably smaller than the Crow. "The crown of its head is black, the nape and throat grey at the sides; the back and the tail also black; the underpart slatey-grey and black. The plumage and eyes of the Jackdaw become whitish in old age. It builds its nest in hollow trees, in the clefts of banks and of old masonry, and in towns between the ornamental parts of buildings. The eggs, which usually are five in number, are of a light bluish-green speckled with dark grey and olive brown.

The movements of this bird are quick and active, it is light on the wing, busy in flight and call. Its cry sounds like "Cáee, Caee." Heard from a height it attracts attention to the approaching birds. Jackdaws usually fly in small flocks; they mix with other Crows and roam about the fields and meadows with them. It is a confiding bird, that not only visits large towns, but actually dwells in them. It is true that it does not despise a brood of young birds, if fortunate enough to secure one; but its principal food consists of the numerous insects, maggots, worms, caterpillars, and other creatures which the plough discovers with the upturned clod in field and meadow. It is pleasant to observe the bird following the ploughman at a distance of five or six paces, watching with its sharp, bright eyes for what the ploughshare may turn up-and descrying, instantly, even the very tiniest grub or maggot. The slight harm which it may do among the young birds or 
the fruit, or occasionally in the young maize ears, is outweighed a thousand times by the services performed for men by this lively, busy bird, as a destroyer of insect pests.

The Jackdaw becomes very tame if caught young; it accustoms itself to life indoors, and becomes attached to members of the household - and can be taught many funny tricks and games. It is a great thief, taking away and hiding any shiny object it can carry. It loves a bath, and immediately paddles about in any little piece of water it can find.

The Jackdaw is found throughout the greater part of Europe; South of Germany it is somewhat rare. Nowhere is it so numerous as in Russia.

Mr. Herman's mention of the Jackdaw's nesting place being in towns among the ornamental parts of buildings reminds me of an act of great apparent cruelty on that bird's part which a friend witnessed and reported to me. He was passing by Apsley House at Hyde Park corner one Spring morning when he noticed a Jackdaw pounce on a Pigeon which was about one of the ornamental parts of that mansion. The Jackdaw literally tore the poor bird to pieces. Whether the Pigeon was invading ground the Jackdaw looked upon as its own domain he could not say; but the sight was cruel enough. That this species is intolerant in nature is shown by the fact that he would hardly ever nest in the same neighbourhood as the Chough when this bird was more plentiful than it is now. The Chough has ousted it-or at any rate taken its place in Kerry and Donegal, and other wild parts of the Irish coast, though it is numerous in 
other districts. Large numbers of Jackdaws come to our eastern coast in autumn.

I have referred more than once to the late Rev. R. Bosworth Smith, but I feel that I must give one other fact here which came to me through a friend of his own who attended his funeral. It has not, I believe, been recorded before. He had a special affection for the bird now under notice. After a very serious operation in London this gentleman - and how truly gentle he was, many a one knows-declared that he wished "to be back amongst his dear birds again" at Bingham's Melcombe old Manor House. In his delightful book "Bird Life and Bird Lore" he has told us of the falling of the big tree in which eleven pairs of Jackdaws had their ancestral home. It fell, crushing an unlucky cow that happened to be taking an afternoon nap beneath it. After its fall, the whole colony of daws sat on the stump and held a conference. Other Jackdaws who had lately been shut out by wirework from the Manor House chimneys, and more whom the churchwardens had banished from the church belfry were also hard put to, at the same time, to find proper lodgings. Their numbers did not, however, diminish, in the grounds, and when their friend came home to die in the midst of his feathered friends, strangely enough a Jackdaw circled round about the church whilst the last service was held for him, followed the coffin to the grave, and hovered about this, and near the friends who were there, until the last sad rites were over. If space allowed one could tell other stories of the strange sympathy between birds and their human friends.

Many a sheep farmer can speak to the services Jackey renders to his sheep in ridding them of their tormentors 
in the shape of ticks, not to speak of the friend he is to the grazier in ridding his beasts of the flies that harass and nearly madden them at times. This goes far beyond making up for the eggs of small birds, pheasants and partridges. It is on record that 400 maggots, each an inch in length, have been taken from one wretched beast, and of the Ox Bot-fly we read that the eggs having been laid in the hair on the skin of cattle and the maggots being hatched out, these eat their way through the skin, and,taking a lodging beneath it, they form large tumours known as warbles. The grub can enlarge this at will through a breathing hole left in the skin. After staying in these horrible quarters for ten or eleven months, feeding on the nastiness there, it creeps out, drops to the ground, and buries itself to pass through the pupa stage, whence it emerges a winged fly. Then there is the Sheep Bot-fly which is worse still, laying its eggs in the nostrils of sheep. The maggots force their way upwards as far as the bones of the forehead where they abide for about nine months, causing vertigo and staggers, and sometimes death. Finally they descend by the nostrils and are got rid of by the poor sheep's sneezing. They get so to ground and bury themselves. From the pupa they pass to the winged stage so as to lay eggs in summer.

Who that has seen our bird on the back of one of these tormented creatures could ever complain of " that wicked Jackdaw."

The gardener also may welcome it with justice. Earwigs and spiders, with their white bags of eggs or young, Jackey makes short work of, also snails. It is true he takes ripe fruit, peas, etc., but we may not grudge one of the very best of our bird lovers a tithe of the produce 
which his own good services have increased immeasurably to our benefit. That ancient poet who wrote of the cave where

" Birds obscene,

Of ominous note, resorted, choughs and daws."

was not so good an agriculturist as one might have expected him to be.

Cowper appreciated the character of the Jackdaw to the full. He says

" There is a bird who, by his coat And by the hoarseness of his note, Might be supposed a crow.

A great frequenter of the church, Where, bishop-like, he finds a perch, And dormitory too.

Thrice happy bird, I too have seen Much of the vanities of men, And, sick of having seen 'em, Would cheerfully these limbs resign For such a pair of wings as thine, And such a head between 'em." 


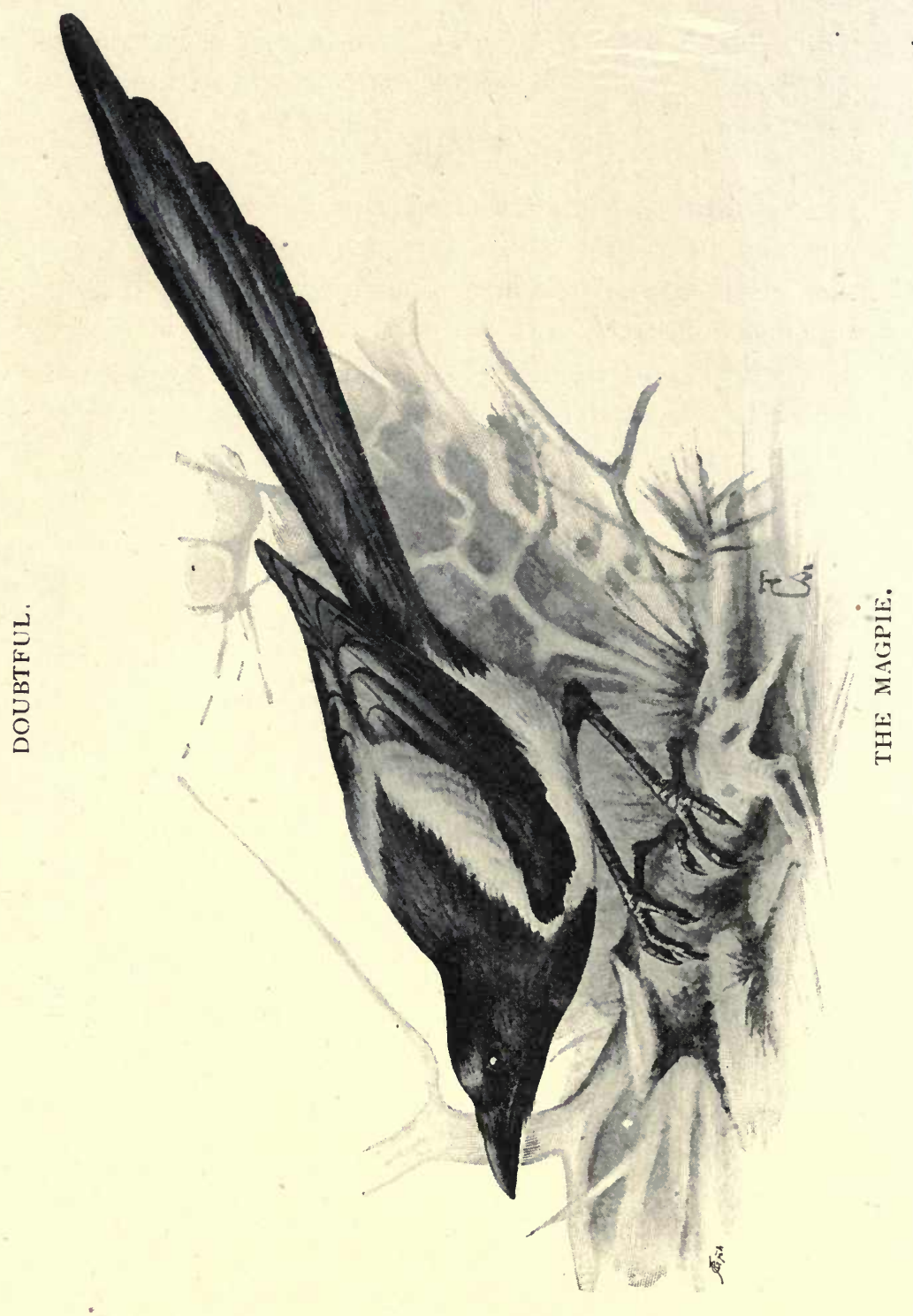




\section{THE MAGPIE. \\ (Pica rústica.)}

This is an extraordinarily clever, sly, and calculating bird, which, although living mostly in the neighbourhood of man, never becomes confiding, though bold enough to steal a young bird off the nest, and make away with it. When a pig is killed, it lurks around for hours with other birds of the crow species, near the spot where the pig is singed and cut open; and at an opportune moment darts down, siezes something, and is instantly back on the roof or we hay rick.

In a hard winter it will come into the farmyard or the village, and filch whenever and whatever it can. It builds its nest, preferably, on a road where rows of acacia trees border the cornfields; a spot which offers a wide field for its activity: doing mischief by decimating the young birds; but on the other hand it destroys grubs and beetles, and in this way is useful. It does, however, considerable harm, and therefore its numbers should be lessened in my opinion.

It is well known that the Magpie steals any shining object it can find. Its call sounds like " Shakerack." There is a saying in Hungary, where it is very numerous, that when the Magpie cries on the roof there are visitors coming.

Game-preservers have managed to destroy more Magpies than Jays in Great Britain, but the Magpie is still fairly numerous and the species is distributed widely throughout our country. In Ireland it is even increasing in numbers. The Magpie confers immense benefits by 
devouring slugs, snails, worms, rats and mice, and these ought surely to weigh against its depredations in the poultry yard, and where eggs and game are concerned.

A number of Magpies together have, under stress of hunger, been known to attack weakly animals, and the late Lord Lilford recorded an instance of fourteen or fifteen of these birds fastening on to a sore-backed donkey in very severe snowy weather, and after the death of this animal, from natural causes, several of the birds were shot as they fed on its body. But what will starving creatures not do if they can fill their empty stomachs? Their keen eyes also see when a fox is growing exhausted, and they will hover and swoop over it in a most suggestive manner.

In point of fact the Magpie robs poultry yards, taking eggs, chicks and young ducks, during the months of May and June especially; but these might be protected. Srme fruit too he will steal; but let us consider that all the year round he feeds on the very worst enemies to agriculture, and that it feeds its young, generally six of these in each nest, on insects chiefly and later on rats, mice, etc. The short-tailed Vole or field mouse of which from time to time our country has a perfect plague " overwhelming the whole earth, in the marshes," said one old chronicler, is especially sought for by the Magpie and these Field Voles have three or four litters in the year, litters of from four to eight young. One writer states his belief that the destruction of Kestrels and Magpies is the cause of the increase of Field Voles. The Rev. J. G. Wood considered that it more than compensated for the harm it did to game and poultry by its good offices in ridding the gardens and cultivated grounds of their varied foes, and Macgillivray gave the bird a good 
character on the whole. Our cattle are grateful for its services; like the Jackdaw it frees them often of the vermin which annoy them so persistently. The large White - or cabbage butterflies, it devours largely, and these feed on other crops beside cabbage, both the leaves and seed-pods of turnips for instance, horse-radish too and watercress. Enormous flights of these insects come to us from abroad from time to time.

It is of course a noisy chattering creature, and, as a child, I remember I had a perfect terror of a tame Magpie that ran after me, pecking at my heels. Its " tricks and manners " leave much to be desired, it must be owned, yet it is an ornament to the country side, and to meet more than one Magpie is considered to be a very lucky omen, that is, I believe, up to six. In Scandinavia it is the bird of good luck, par excellence, and its presence is much desired about the homestead.

\section{Montgomery wrote:}

"Magpie, thou too hast learned by rote to speak Words without meaning through thy uncouth beak."

but the Magpie retorts :

"Words have I learned, and without meaning too, Mark well, my masters taught me all they knew."

Head, neck, throat, mantle, rump, and thighs black; breast, underparts, shoulder and the inside of the wing feathers pure white. This gives the bird a very pied appearance. The tail is long, arrow-shaped, and like the wings have a beautiful metallic lustre. Its nest, 
which is a work of art, is built in trees. Dry twigs and thorns form the foundation, and on this lies the cup made of earth or clay and lined with fine roots, leaves and hair. Over this is a domed roof of thorns and twigs : the opening of the nest is at the side. The clutch consists of four to seven eggs of greenish grey speckled with brown.

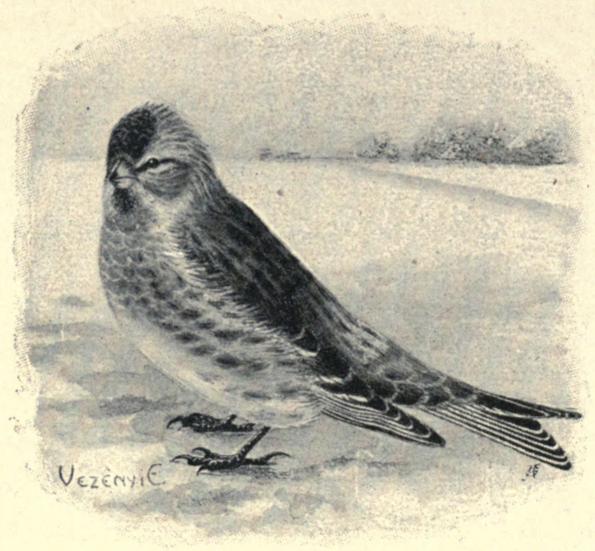

Out in the Cold. 


\section{THE JAY. \\ (Gárrulus glandárius.)}

Wherever this bird is found woods and gardens ring with the sound of its voice. Its usual cry sounds like "Matyash" (Hungarian for the name Matthias) by which name it is consequently often called in that country. It is an active, restless visitor to the bushes and gardens, when they are near a wood. It is not dainty and its voracity is great. Nuts, filberts, acorns, beechnuts, fruits, berries, but also insects from grubs upwards, grasshoppers, beetles, - everything finds its way into its crop. Such things as nuts and filberts, which have a hard shell, it collects in crevices and holes. All this is not so bad, but another of its habits is evil-it is a nest plunderer. Eggs, naked fledglings, half-fledged young, sitting on the edge of the nest awaiting the mother's return - all become its prey. In order to reach them it squeezes through the thick growth of the whitethorn. In fact it is a shameful bird that deserves no consideration.

If caught young and kept in a cage or running about the house, he is often found to be an amusing fellow, even if not quite tame,--and proves himself a perfect master in imitating the notes of other birds. In the iirst place he learns the noises of the domestic fowls and animals. He chirps like the little chickens, crows and cackles; then he howls like the dog, cries like the cat, squeaks like the unoiled hinges of a door, or a cartwheel. He answers the Cock, like a cock, the goose, like a goose. His usual cry is a screeching "Retch" or " Rey "- or when in fear " Kay " or " Kray." 
DOUBTFUL.

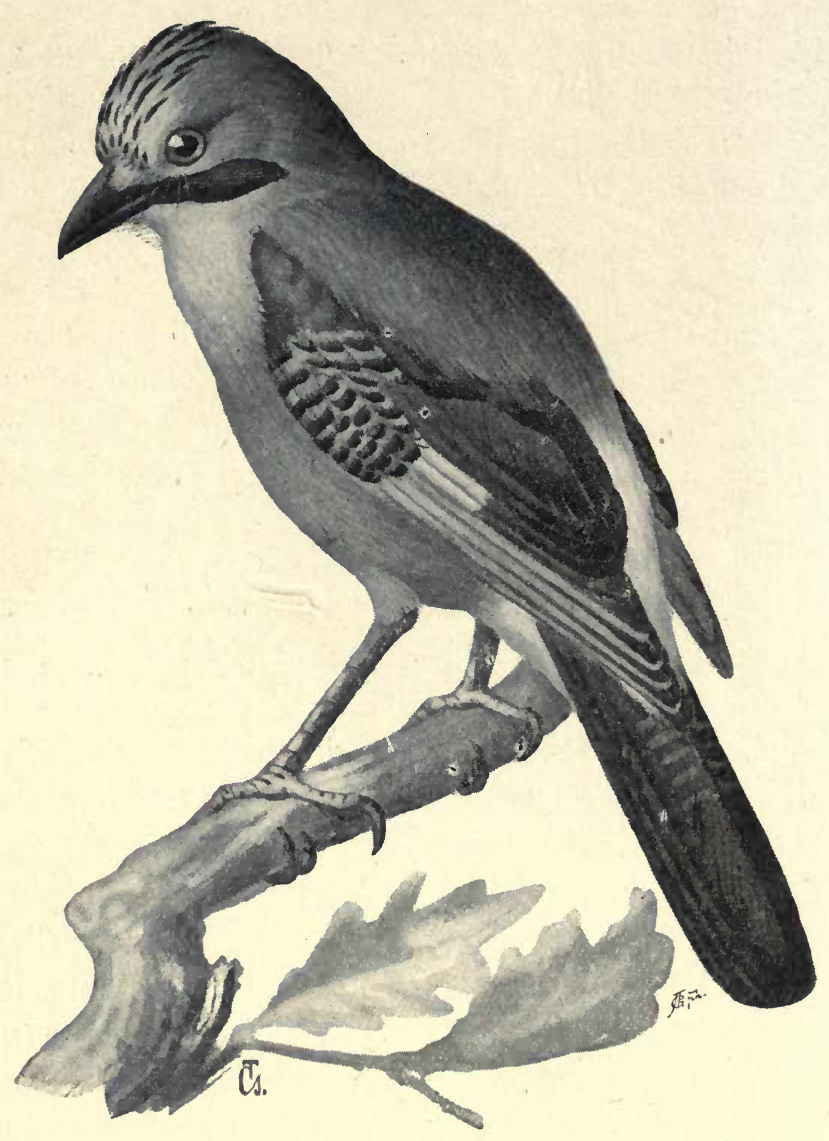

THE JAY. 
It is fairly numerous with us, and is on account of its brilliant plumage, an ornament of the woods.

In Great Britain the Jay finds little consideration, save from the makers of artificial flies, after he has been shot or trapped. The lovely blue wing-feathers are used by these men. Gamekeepers also show him scant mercy. Still he manages to hold his own in the woodlands and is fairly common in England and Wales. In Ireland its numbers are fast decreasing. On the east coasts large flocks sometimes arrive from the Continent to stay for a time; but the Jay is of course resident with us as a species.

The Jay is perhaps now receiving a little more toleration than formerly. It devours worms and insects, certainly, and to a considerable extent. A Son of the Marshes puts it in a light which is worthy of consideration. To quote from "Nature's Raiders "- "The Jays have scant mercy shown them as a rule. On some estates extreme measures are carried out against them but this is not always the case. Taking their numbers into consideration, they cannot be half so hurtful as they are represented to be from the gamekeepers' point of view, or they would be thinned off more. Jays are excellent covert guards in the daytime in the same way in which the peewits, at night, guard the fields which they frequent. Both birds give tongue as it is termed. To the small allotment holders who have their cultivated patches in sheltered hollows close to the woods, this bird must be considered as a feathered benefactor, for he will, if allowed to do so, keep within due bounds the small raiders that play havoc with their garden produce. Recently I saw at least a dozen watching for--and cap- 
turing also-some of the wood mice that had ventured out on the sunny slopes of the allotment grounds. As the crops were vegetable ones the less attention these have paid to them by the mice, when in a young state, the better."

The voice of the Jay is against him, however. It does not evoke sympathy. Montgomery wrote:

“ Thou hast a crested poll and 'scutcheoned wing Fit for the herald of an eagle king,

But such a voice! I would that thou could'st sing." And the Jay retorts :

" My bill has rougher work, to scream with fright, And then, when screaming will not do, to fight."

The Jay is smaller than the Jackdaw. Its plumage is reddish grey, the bridle wide and black; crown nearly white with dark longitudinal flecks; rump and undertailcover white; on the wings a white spot; tail black,--with pale blue cross bars. Its great beauty is due to the upper wing feathers which are striped with white, black and a beautiful blue. It has bright shining eyes of light blue. The nest is built in trees, sometimes high, sometimes low, and five to nine eggs are laid, which on a pale, usually greenish, ground are thickly speckled with dark but delicate spots.

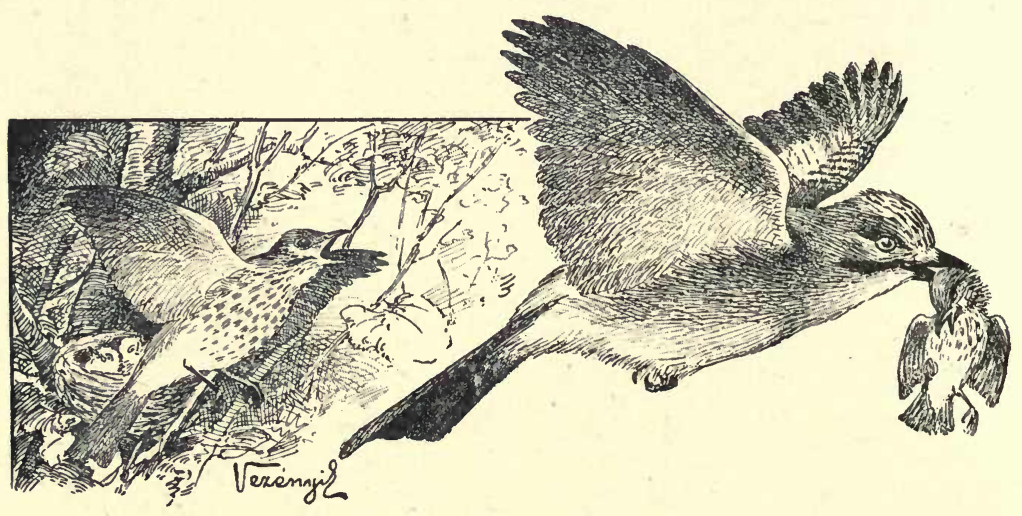

The Jay as raider. 
THE BLACK-HEADED GULL.

\section{(Larus ridibundus.)}

This Gull is a migrant in Hungary. Many, however, pass the winter with us, leaving the frozen inland waters for the open streams of the rivers, where they pass their time until spring returns. It has quite adapted itself to life on land, and there is no bird which more assiduously follows the plough in those districts where it has its nesting place on the inland waters, or more zealously clears the cornfields, meadows, and rush-beds of all kinds of noxious worms and grubs, than this gull. It also feeds its young on these insects, and many of the landowners, have to thank the Blackheaded Gull that they are free from the annoyance of these pests. It frequents the ponds and lakes, however, in autumn, and makes havoc among the little fishes. Its screeching call can be heard at a great distance, "Kreā, Kreā," or "Krackackark."

It is an exceedingly useful bird, and ought to be protected.

This species is generally distributed on our shores all through the year in Great Britain, but in spring it betakes itself to marshy places near the coast and to inland lakes and meres. Near Poole in Dorset is a colony of these Gulls, they ought rather to be called Brown than Black-headed; on the coast of Essex, several in Norfolk, small ones in Yorkshire - one large one near Brigg in Lincolnshire; and those of Aqualate Mere in Staffordshire and Norbury have existed for some centuries. In many other districts to the North they are even 


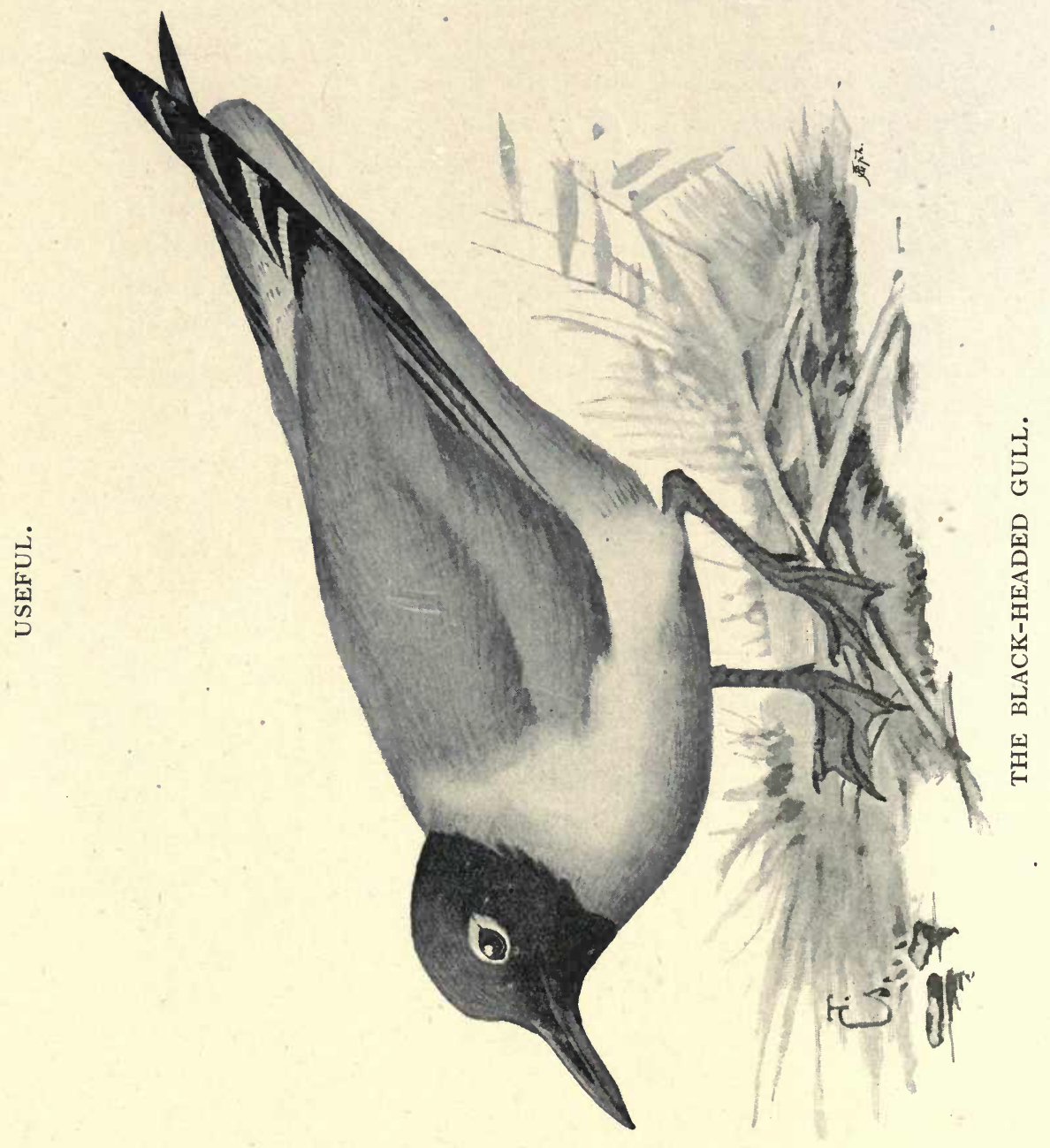


more plentiful-right up as far as the Shetlands. In Ireland it is the commonest species of its family.

To the farmer the services of this Gull are invaluable. Like the Rook it follows the plough, devouring vast quantities of worms and grubs. It can capture moths and cockchafers on the wing, and will eat indeed almost anything, acting also like others of its congeners as a scavenger of the foreshores. Farming in districts near the coast benefits greatly from the services of these birds. They are partial to snails also, and as no Gull feeds on plants, seeds or fruits, a Gull in a garden, wing-clipped, is often kept as a useful pet.

This Gull is sixteen inches in length, that is almost as big as a crow. The beak is not strong, the point is curved downwards; the head a beautiful dark-brown. This colour extends to the throat. There is a white ring round the eyes. Neck and mantle a beautiful ashengrey, throat, breast and underparts white, with pinkish tinge; outer primaries dark with white stripes. The upper parts of the wings are light grey; beak and legs carmine, also the irides and their borders; the toes are joined together by a web. The head becomes white in winter, the beak and feet lose their brilliant red colour and become flesh colour, and then brownish. It nests with others in settlements consisting sometimes of 3000 to 4000 nests. The nest is placed on broken reeds, turf clods, tufts of rushes; the bird, without much skill, makes a little heap, scratches a hollow in it, smoothes the inside, prepares a litter of dry rush and sedge leaves, and the nest is finished. The nests are placed close together. The clutch consists of two or three eggs, very rarely four, usually of a yellowish clay colour, marked, or regularly speckled with a dark shade. 
USEFUL.

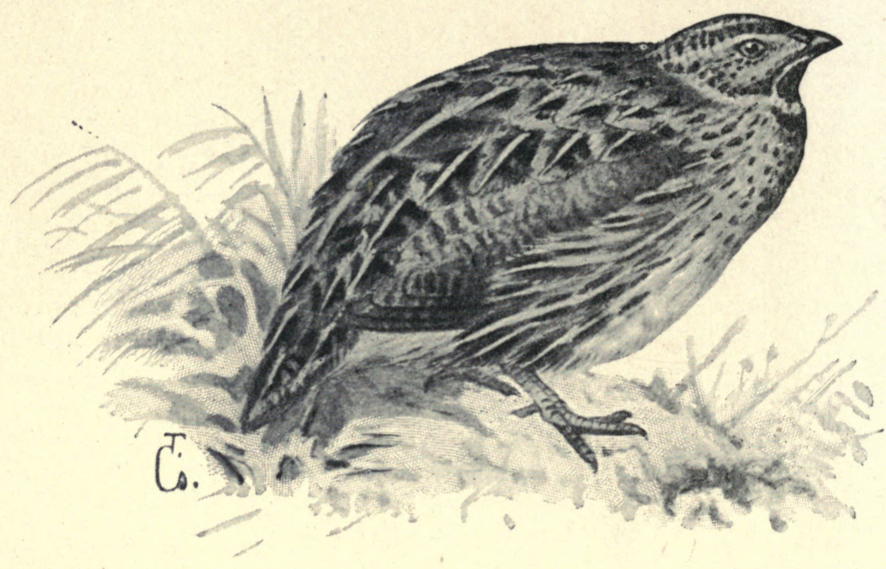

THE QUAIL. 


\section{THE QUAIL. \\ (Coturnix commúnis.)}

The Quail is about the size of a large clenched fist, and is almost as round as a skittle ball. Its entire plumage is clay-coloured speckled with a darker shade, and marked with light lines, like the head of oats. The whole marking of it, especially of its back, is designed to avert man's attention from this crouching bird. The throat of the cock is black, the beak and legs like those of the barn-door fowl. The bright eye light nut-brown. The nest is placed on the ground, and is simply a scratchedout hole, which is rather littered than lined with blades of grass. In this the female bird lays her eggs of olive yellow, beautifully speckled with brown, sometimes to the number of sixteen, but usually ten. The chicks run after their mother as soon as they are hatched and dried - which is a very pretty sight. They can make themselves invisible by crouching on the ground, so that the colour of their down assimilates with that of the earth.

The habits of this bird are those of the domestic fowl. From early morning till evening twilight, the Quail is on its fect, searching the ground for grains of seed or little beetles. It scratches like a hen, and when it finds a sunny, dusty or sandy place, it bathes in the sand, flinging the dust all about. The Quail is a useful birdfor it picks up only the seed which lies on the ground, and feeds it young with the same. It therefore deserves shelter and care. Its voice and habits are pleasant and agreeable to man. Its familiar and homelike cry, sounds from out of the cornfields, and the little hen answers. The mating call of both is, "Bue bee wee." 
"Ah! what sweet accents fall softly around, Praise the Lord! Praise the Lord! (Fürchte Gott!) Murmurs the quaint little quail from the ground." *

The bird's cry of " Bit by bit," and his mate's reply, "Wet my weet, Wet my weet," as we render it, is not often heard now in our own country. This is attributed by some to the fact that most of the Quail's favourite feeding-grounds have been " improved" away. Fine pasture-lands are now where the ground was once coarse and covered with tussock, bent, thistles, burdock, hawkweed, and such plants as flourish in uncared-for lands, and in such surroundings the Quail delighted to remain. Now, only very few winter with us; the majority leave in October for the South.

The Quail is an accomplished ventriloquist, and the late Lord Lilford, in his " Notes on the Birds of Northamptonshire," says that he often heard a caged Quail calling when within a few feet of him, which yet gave the impression of being many yards distant. On the western side of Corfu he found numbers of these birds in the currant-vines on very steep hill-sides, and vast numbers are bred in the cultivated plains around and below Seville, where their numbers are thinned in the pairing season by a clever method of calling the birds into a net by imitating the call-note of the female. On the island of Capri, in the Bay of Naples, it is on record that as many as 160,000 have been netted in a single season.

Many of us have eaten them in the South of France during the grape season. The birds can be caught by the hand when they have, as the French say, intoxicated *See Beethoven's song “The Call of the Quail." One of Antoinette Sterling's favourites. 
themselves by feeding on the ripe grapes. During the winter and the early spring they feed on the seeds of the plantain, dock, vetch, and chickweed. Slugs also and insects help to form the bird's diet. The Italian's notion that it is unwholesome to eat Quails at a given season arises, no doubt, from the fact that it is pleasanter eating and the flesh is plumper at certain times of the year than at others, owing largely to the varying nature of the bird's food.

The Quail is a favourite pet in Spain; the birds are kept much in cages there, and are valued because of their song; and that the Quails have been taken on the Continent in vast numbers when netting them, at the time of the vernal migration, is not to be denied. " We remember," says Lord Lilford, " seeing a steamer at Bressina, in the month of May, 1874 , one of whose officers assured us that he had six thousand pairs of Quails alive on board, all destined for the London market. The unhappy birds are carried in low flat cages on boxes, wired only in front, and it is surprising what a very small percentage of them die on the voyage, unless " a sea" happens to break over them. They thrive well on millet, and soon become fat; but, in our opinion, this traffic should be prohibited, as the unfortunate birds are caught on their way to their breeding quarters, and some of them at all events would afford sport at a legitimate season when naturally fit for the table." "Chaud comme caille," says the French proverb, because Quails are exceedingly amorous and pugnacious at the time of pairing. They thrive well in confinement, and are easily "fatted up" for the table. 
USEFUL.

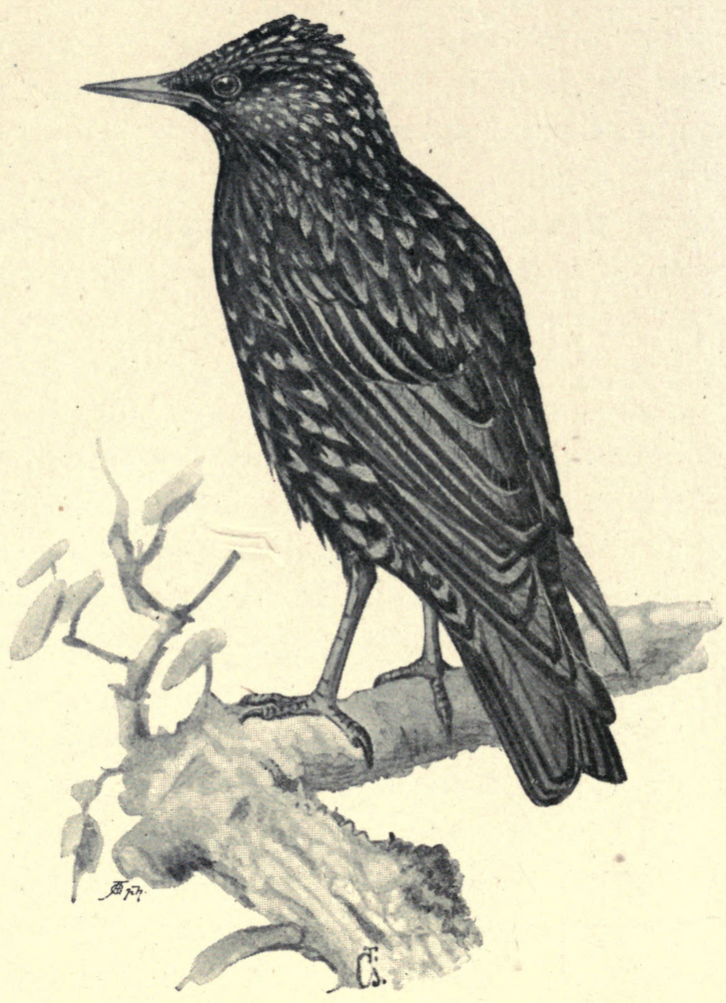

THE STARLING. 


\section{THE STARLING.}

(Sturnus vulgaris.)

The Starling is a very lively, jovial bird, very active, hunting about, and chattering over what it snaps up. It is also very sociable. These birds often collect in such numbers, in places, where a wood is bounded by pastures or reed-beds that when the flock rises together, it throws a shadow like a dark cloud. It specially seeks out flocks -cattle, horses, sheep or pigs, and stalks about in their shadow, under the very noses of the wallowing swine, in order to drag out of the earth the desired worms, in company with the Blue headed Wagtail. It also perches on the bodies of the beasts, and operates on them where there are maggots or worms. The animal knows the bird is doing him a good turn, and remains perfectly still.

It is true that this bird also attacks cherries, blackberries, raspberries and grapes; and, if present in numbers, it does, indeed, considerable harm.-Then it must be frightened off with rattles, blank-shot, and whatever else is of use. Still, the year through, it does a thousand times more good than harm and therefore deserves to be protected and cherished.

It becomes very tame and trusting in captivity and can be easily taught. It can learn to sing tunes and speak words-and becomes attached to its owner.

Mrs. Edward Phillips of Croydon rescued forty starlings once from the pockets of a working man who said 
he was selling them to serve as pigeon dummies, in shooting matches amongst his friends. Needless to say she paid for and set them at liberty. I was struck wtih the scarcity of Starlings in the centre of France, and country folks there told me they were getting scarce. Perhaps they were not much protected, for I saw in Anjou a family of the young birds in the hands of a boy who told me he was carrying them home to train for sale as singing and talking pets. They are not good to eat and yet they will feed on them in that part-birds these that, if spared, eat up tons of those grubs and larvæ which ruin the crops in the field. Sometimes even they have been shut up and fed on vegetable diet to make them tasste better. This has only made the bird thinner, proof positive that the enemies of " green stuff " and not itself form their natural diet. Feeding as they do at all seasons on our pasture lands the services they render are incalculable.

In November, or somewhat earlier, they arrive on our east coasts in great numbers; whilst others migrate westward, deserting some localities entirely for a tîme. Great numbers also visit the South of Ireland then. They settle on the salt marshes for a while sometimes; but often they pass on further inland in perfect silence, with a swift direct flight, and a way altogether unlike their usual chattering fussy ways. They begin to pair in January in some of our districts. Naturalists call them Ambulatores, or walking birds; they are quaint creatures in all their ways and habits. Of late years they have been accused of pecking into apples more than is desirable. As the season advanced, and fruit was not so varied and plentiful, I used to find that when all the leaves were off my pear trees-in a former home-they 
ate the few pears that were left hanging high up until nothing but stalk was left, but they touched neither apples nor pears whilst the leaves were on the trees.

The best way of keeping Starlings away from high cherry trees, that I have seen, is fixing a long narrow flag to a strong top branch. Large flocks of them resort to cowfolds, where the stock are all night, and before these are let out the birds are there seeking for larvæ and worms in the dried dung, perching now and anon on the backs of the cattle, chattering low all the time. They rid trees of caterpillars, and the turnip fields, where they have been known to clear these of "fly" ; also to visit field peas that were infected with aphides and do good work there; and they devour great numbers of Daddylonglegs. Waterton, - that past-master in the art of observing and chronicling the doings of birds, wrote: "There is not a bird in all Great Britain more harmless than the Starling : still, it has to suffer persecution, and is often doomed to see its numbers thinned by the hand of wantonness or error. The author of 'Journal of a Naturalist' observed a pair of Starlings having young ones for several days, and he wrote, 'It appears probable that this pair, in conjunction, do not travel less than 50 miles a day, visiting and feeding their young about I40 times, which, consisting of five in number, and admitting only one to be fed each time, every bird must receive in this period twenty portions of food."

In I89I twelve farmers, replying to Miss Ormerod's question as to which kinds of birds were specially useful in destroying caterpillars, all replied in favour of the Starling. Now what, after all, matters a little fruit taken from private gardens in view of all this good work done. And as to the professional fruit grower, it will pay him 
to employ a boy or two during a short season of the year, to keep birds off his trees.

Sir Herbert Maxwell, who writes on the whole in favour of Starlings, and remarks truly that all naturalists are agreed that the good they do outweighs the evil, says that "from many a dovecote the legitimate occupants have been expelled by the intrusion of these irrepressible creatures." And Waterton wrote, "The farmer complains that it sucks his pigeons' eggs, and when the gunner and his asscmbly wish, the keeper is ordered to close the holes of entrance to the dovecot overnight, and the next morning three or four dozen of Starlings are captured to be shot .... Alas! these poor Starlings had merely resorted to it for shelter and protection, and were in no way responsible for the fragments of egg-shells which were strewed on the floor ... The rat and the weasel were the real destroyers," etc.

The Starling is as big as a thrush; it has bluish iridescent plumage, the feathers tipped with white. Beak relatively small, brow flat; eyes near the base of the beak, which gives it a cunning expression. The feathers are small and tapering at the point; beak yellowish. The hen is paler, the young ones still more so. The legs are strong, with sharp claws. It selects for its nest holes in oak trees in the woods near which is pasture land or water stocked with reeds and rushes. In warmer regions it breeds twice in the summer. The first clutch consists of five to seven eggs, the second of four or five of a pale light blue colour. 


\section{THE ROSE STARLING. \\ (Pastor roseus.)}

In Hungary this bird is only a summer guest, and single pairs may be met with in various parts of the country. Its appearance in large numbers always coincides with the time of the grasshopper plague;-a fact which was first observed in 1814 . The distinguished Hungarian ornithologist, Petényi, described his observations in 1837 . He states that, so long as the grasshoppers are not fully developed, the bird feeds on all sorts of insects; but as soon as the grasshopper is sufficiently matured, this insect forms its sole food, and is pursued with great eagerness. Thus, in the year 1907 great numbers of Rose Starlings appeared on the well-known Puerta of Hortshágy where just at that time the grasshopper plague was raging. There we may enjoy the spectacle which Petényi described as follows: "To the eye of the beholder a flock of these birds in flight has the appearance of a roseate cloud, always moving, -backwards, forwards, sideways, in ever changing forms of beauty-or, alighting, they give an exquisite impression of whole bunches of wandering roses moving on the green turf.",

Although the Rose Starling also loves fruit-berries and causes such damage to them by its great numbers, that in some parts it is called the "devil's bird"the fact remains that its chief food is the grasshopper. In Tartary, its native land, it destroys the locusts which in former times visited Hungary. A Turkish proverb says that the Rose Starling kills ninety-nine grasshoppers before it eats one. When a flight of these birds descends upon a grasshopper infested district, it consumes 
an enormous number of these insects, and that, in places where human defences can do nothing; in this consists the value of its actions.

Among the grasshoppers found in Hungary at the present time are the Stauronatus maroccanus and in smaller numbers the Colopterus italicus, the latter of which belongs naturally to the Hungarian fauna.

The note of the Rose Starling is a harsh and continuous babble. This bird is protected in the Caucasus and elsewhere because locusts are the favourite food of both the old and the young birds. In the East it is said to be, however, very injurious to grain during the colder season; also I believe, in Africa. This beautiful bird has occurred of late years in most parts of Great Britain, but only, alas, to be shot and "stuffed." As a rule it visits us in summer and autumn, single birds, perhaps separated somehow from flocks of their own species. In such a case they generally join our own Starlings.

This beautiful species is the same size as its congener, the Common Starling, and it resembles the latter in form although so much smarter in appearance. Rump, back, shoulders, breast and underparts are a bright rosy pink, head, neck and throat are a glossy black, wings and tail are a metallic greenish-black. The bill is a yellowish-pink, black at the base; legs yellowish-brown. The long crest of the adult male is composed of fine violet-black feathers. The female is not so brightly tinted and has a smaller crest. The nest of the Rose Starling is built in its own native home in south-eastern Europe in some crevice in a ruin in quarries, cliffs, or among stones in a ravine or a railway cutting. The clutch consists of five to six eggs of a pale bluish-white colour, or pale bluish-green. 
The Waxwing.

(Ampelis garrulus.)

THIs beautiful little bird has its nesting place in the far north. It often visits Mid-Europe in winter in great numbers, principally frequenting juniper plantations, where it is easily snared. Its flesh being a great delicacy, it is much sought for. Moving along the headlands it passes also into the valleys, and even visits the gardens and parks of great towns, especially where mistletoe is found on the old trees. When in need it eats seeds; it also feeds on the berries of whitethorn, mountain ash, hawthorn, and other bushes. It has a good appetite and digests its food very quickly, but is somewhat inactive in its movements. It lives in colonies sometimes smaller sometimes larger. Its breeding range extends across Behring Straits to Alaska and the Rocky Mountains.

The Waxwing visits Great Britain at irregular intervals, often in large numbers, during the winter. Being an inhabitant of the Arctic regions, its visits are more frequently paid to the Northern and Eastern sides of the country, but it has been seen often in the Southern counties. In Norfolk, on the spring migration, it is sometimes seen up to the first week in May. It is a silent, gentle-mannered bird and its only note is a low cir-ir-ir-ir-re. It is essentially a wandering species and is very erratic as to its nesting places, belonging to the class the poet refers to in those lines

"The birds of passage transmigrating come, Unnumbered colonies of foreign wing, At Nature's summons." 


\section{USEFUL.}

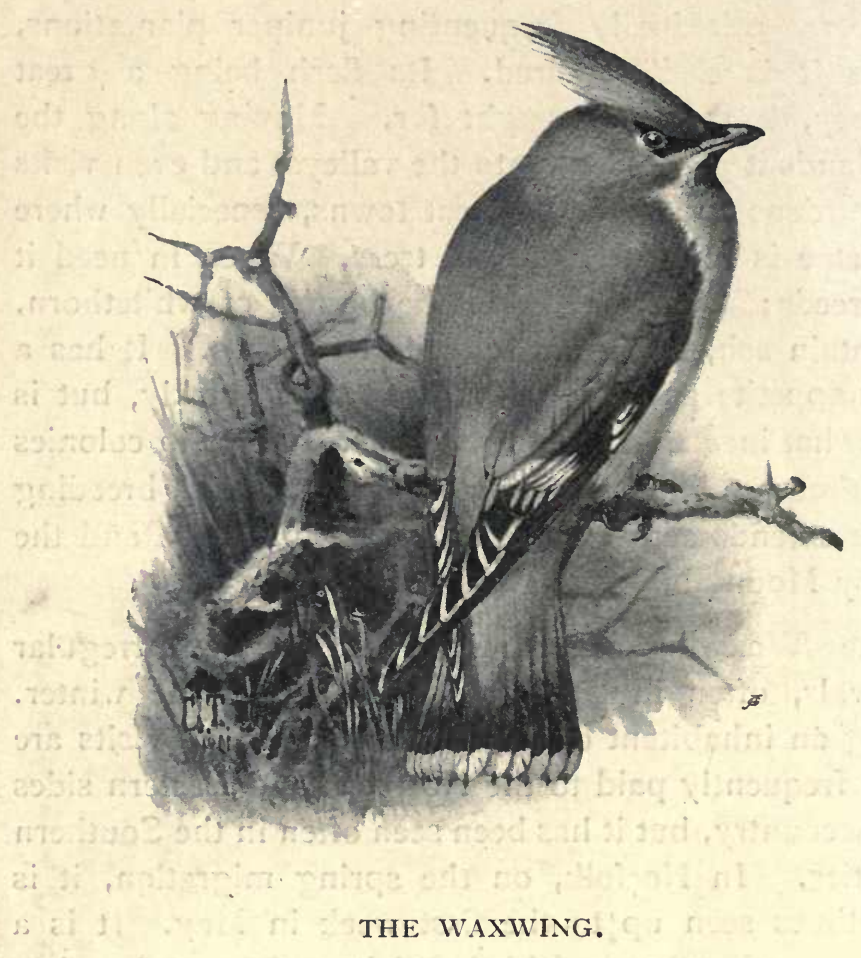

bri:s

An erratic winter visitant. 
The Waxwing has a very silky plumage. On its head is a crest, inclining backwards, which can, however, be erected at pleasure. Throat smooth black; back cinnamon-brown, underparts a lighter shade of the same colour. Tail black with a golden-yellow border at the end. Wings black with white bars. The outer half of the secondary wing feathers yellow, with white border at the end. The shafts of these feathers are tipped with red horny appendages like sealing-wax, which also appear on the tail feathers of the adult male. 
USEFUL.

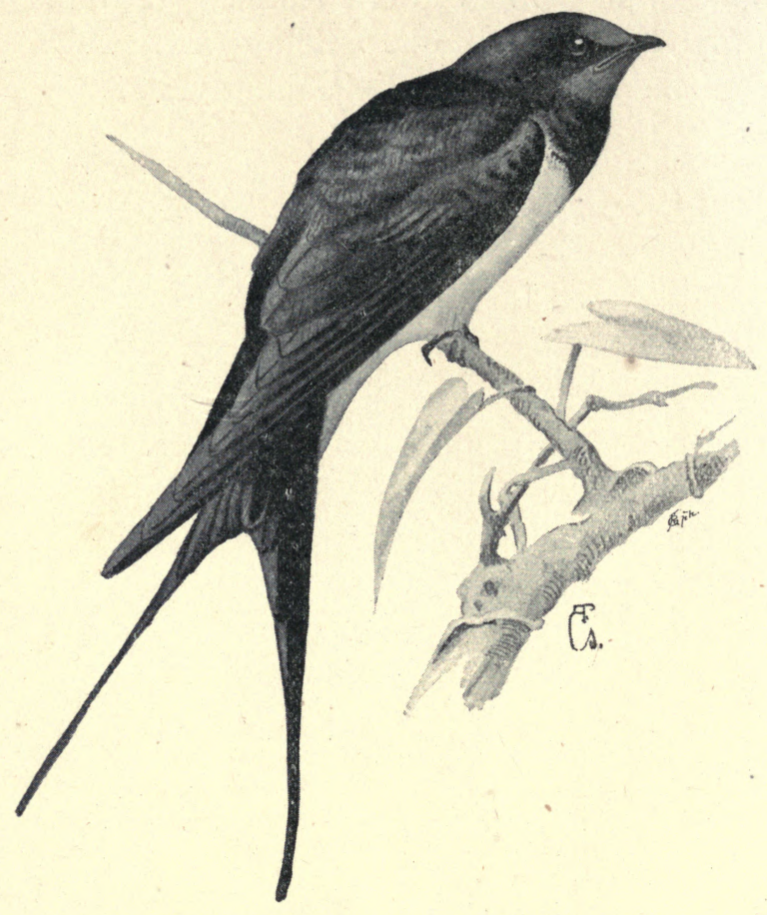

THE SWALLOW. 


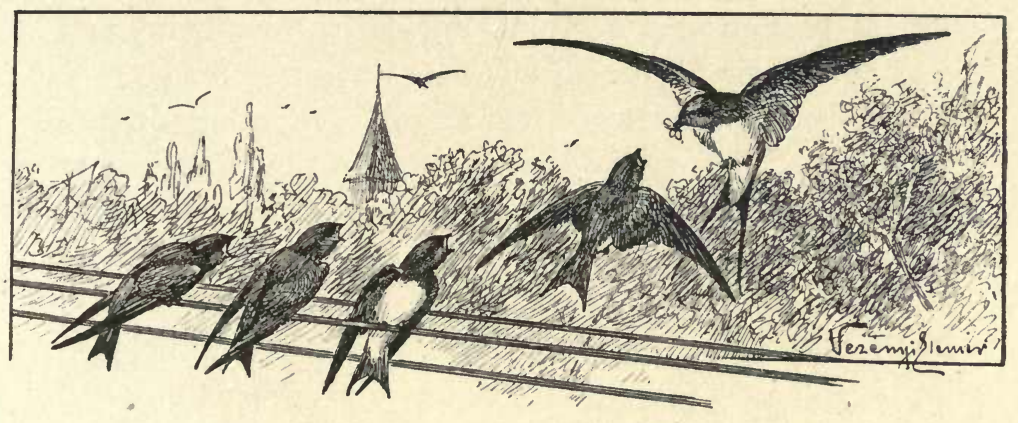

CHAPTER IV.

\section{IN THE AIR AND ON THE TREES.}

The Swallow. (Hirundo rustica.)

THE nest of the Swallow is in the shape of half a saucer, quite open, and formed of clay, into which straw and grass are cleverly kneaded. It is built in old huts, in chimneys, also under the eaves of houses, often so low, that it can easily be reached by an outstretched arm. This bird is truly a household companion with us in Hungary. The first clutch of the year consists of five to six eggs, the second which comes at Midsummer, of three or four; they are white, speckled with reddishbrown and grey.

It is a pleasure for man, to observe the daily life of the Swallow. In spring it returns to its old nest, tidies it up, and then its domestic felicity begins. In the early morning light, it may be seen sitting on the roof, on the window-sill, or on a post, cleaning and arranging its plumage; then it wakes the household, 
with its twittering morning song. Next husband and wife begin their flight. Swift as an arrow, off they go, seizing flying insects and caressing each other on the way. The Chimney Swallow, when on the wing, utters a hasty "Beeweest, beeweest," especially if it is alarmed. Its cry is a tender "Weet" or "Weeda weet."

Soon comes the brooding time; then, the young ones slip out of the eggs, and the work of feeding and educating begins. The parents take it in turns to perform these duties, which they do with the greatest industry, and even when the young ones are as big as themselves, and fully fledged, they still place them in a row on some bough, and bring them food. It is beautiful to see with what fidelity this is done. It is a sight to move heart and mind with tenderness, and this is the pet bird of our people, who care for it, and gladly give it shelter and protection; not however, that of the Southerners, who catch and cook Swallows by hundreds of thousands.

We hear from all parts of the country of the scarcity of Swallows, and various theories have been offered as to the reason of this. In France their numbers have been for years systematically reduced by the snaring and destruction of them, in various ways, for table use. An instance of this I can personally vouch for. A doctor in Nismes, the brother of a friend of my own, who is keen on bird protection, being in the market one day, was pressed by a poulterer to buy Larks. When he refused, the man, thinking the price was too high for him, took him aside and showed him two hampers apparently full of these birds, which are allowed to be 
sold there, whereas the massacre of Swallows is illeg .1. On the top was a layer of Larks, underneath were Swallows only. " These I can do cheaper," he said.

The Midland farmer I alluded to before, Mr. E. Hancock, who writes to me at times, and who has commented on the few Swallows about, sends me a story of a pair nesting in his bedroom. They built over a picture frame, brought out their young successfully, and the youngsters having gone out into the wide world, the two parent birds remained in the home. One roosted regularly on a clock in the bedroom, the other upon the picture frame. It is possible that this pair, or one of them, was hatched out on the picture at Great Bealings House, Suffolk, of which I have written elsewhere. Who can tell? A few days ago they began cleaning, relining and repairing the nest, making all ready for the coming of their second brood.

Lady Farren had little silver rings put on the young of the second brood hatched over the portrait in the bedroom at Great Bealings. A bird, with the ring still on came to breed in that same place two years later.

The poor Swallows often suffer terribly from storms and unseasonable weather coming after they have left their warm winter quarters. Mr. Poole, of Ealing, told me that being at his angling quarters on the river Kennet, Ham Bridge, near Newbury, on April 25, 1908, at 8.15 a.m., he saw Martins and Swallows hawking flies, most probably the grannow, as there had been some previous hatches of this fly noticed. The season earlier had been a warm one and these birds had arrived early.

It was snowing hard at the time, and had been doing so for some few hours, and three or four inches of snow 
lay on the ground. All that day it snowed continuously, ceasing only at about 7 p.m., with a fall nearly two feet deep. The frost was occasionally severe during the day. On the morrow, April 26, it was intensely bright, and even hot in the sun, the snow disappearing very quickly; but, said Mr. Poole, "I saw not a sign of either Swallow or Martin and indeed they were scarce on the Kennet for the rest of the season. I also noted a great scarcity upon the riven Itchen, in Hampshire."

A lady also tells me that near Lynn in Norfolk, during the great cold, the hungry Swallows came down on her garden lawn and picked up the scattered crumbs of bread.

Probably numbers perished of cold and hunger. As Swallows live entirely on insects, the diminution in their numbers is a serious matter.

It is sometimes necessary, in order to preserve the proper order of things, to describe what every one knows. The most striking criaracteristics of the Swallow, which distinguish it from its congeners are as follows : Brow and throat a beautiful chestnut brown; breast, back, wings, and tail a fine black with a bluish metallic lustre. With regard to the tail however, only the two middle feathers are pure black, on the others small whitish specks are discernible. The outer tailfeathers form a long pronged fork. The underparts are sometimes white, sometimes brownish. The beak is very small, the gape wide. The open jaw forms a kind of little pocket. The legs are small with sharp claws suitable for grasping. 
The House Martin.

(Chelidon urbica.)

While the Chimney Swallow builds inside houses, under some circumstances even in the fire-place-thus becoming a beloved member of the family,-the House Martin constructs its strong and comparatively large nest on the outside of the building. In mountainous districts it is found also in an overhanging position on the steep rocks, where it is sheltered from the rain. In many villages, where windows and doors of the upper floor are kept shut, so that the Chimney Swallow cannot come in, the latter is not found, and the House Martin then takes its place.

This Swallow also lives entirely upon flying insects. It spends most of its time on the wing otherwise it could not live. It has, consequently, small, weak legs, which are only useful for clinging. It is as useful as its relative but has less confidence in man; it is less familiar. Neither does it please our ears with such a pretty twittering, and its enclosed, remote nest, affords us no insight to its family life. It arrives later in the spring than the Swallow, and assembles in the autumn in flocks, on towers, trees, roofs of houses and churches. One fine day we find they are all up and away-for the distant South.

This bird deserves every care and protection.

I had been watching with interest the building of some nests of the House Martin one season, and enjoying the sight of the pretty creatures as they circled about a house I was staying in for a time, and the way they 


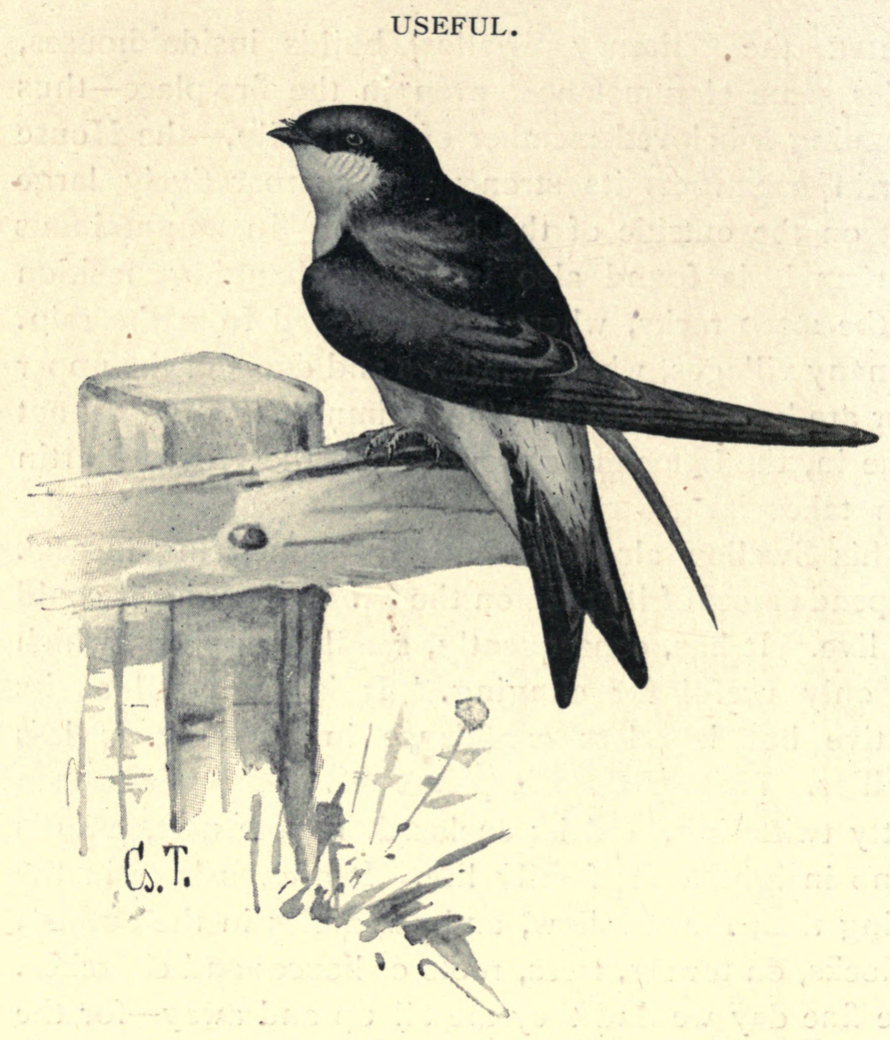

THE HOUSE MARTIN. 
dived in under the eaves. But those bold marauders the House Sparrows, whom over-feeding and indulgence have corrupted and made indolent, forcibly took possession of these homes which were ready for immediate habitation. My neighbour literally fought the intruders, brandishing a clothes-prop from her open bedroom window for several mornings and evenings. The Martins forsook the nests at last in dudgeon, worn out with anxiety as to their homes which are now empty, for my friend declares no Sparrows shall have them. This is one of the worst indictments against the Sparrow, as we all prefer the graceful and useful House Martins about our homes; and through this evil habit of the former their numbers are greatly lessening.

There has been a general complaint of late years that the numbers of the Swallow family are decreasing. This is an international question. If the Southern European States net and kill Swallows and other small useful birds which are passing through on their migratory flight, the more Northern States naturally suffer loss. That is why many of us regret greatly that England has not as yet seen her way towards joining that International convention for the protection of wild birds which had its first beginning in Germany in a little band of foresters and to which nearly all the European States excepting England now subscribe.

The whole study of the migration of birds is full of interest and, indeed, of mystery, much as we have learned of their life history during the last fifty years. As a humble student of bird-life, glad to learn all I can from other students, I have found that those who know most about this wonderful migration are the most modest in making definite assertions in the matter. So little, 
they will tell one, is as yet absolutely established fact, "the way of the bird in the air" is still shrouded in mystery.

The House Martin is smaller than the Chimney Swallow and is easily distinguished from it. At the first glance we are struck by the two colours of its plumage, black and white. Throat, breast, underparts, and also the rump are white; beak, neck, mantle, wings, and tail, black. The little legs are covered in front with white down, like little trousers. The throat is less white than that of the Swallow. Its nest is half-globular, built of clay, and has only a very narrow opening. It builds under eaves, or cornices, in sheltered places on houses and churches, in whole colonies, sometimes in groups, also one over another like a bunch of grapes. It lays five, sometimes seven white eggs.

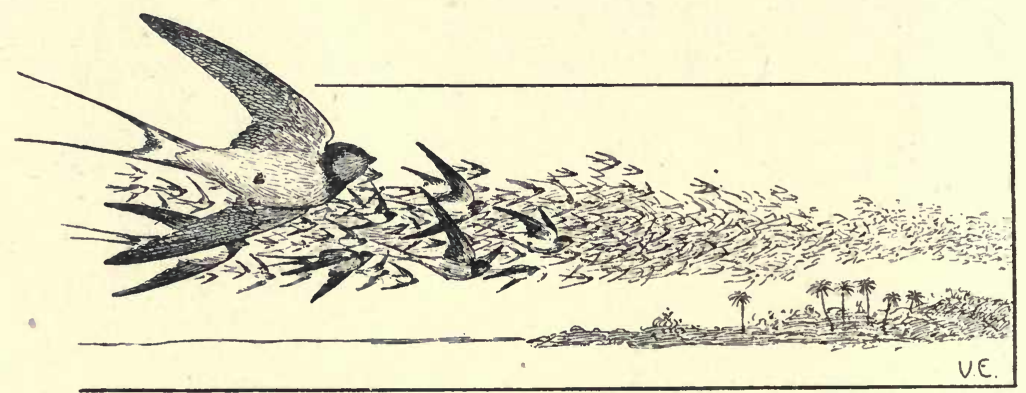

The Swallow's Flight. 


\section{The Sand Martin.}

\section{(Cotile riparia.)}

THE Sand Martin flies quickly, but not with the arrowlike speed of the Chimney Swallow. It dwells on the waterside, where it nests in colonies of hundreds, even thousands. The nest is composed almost exclusively of earth, and is placed in the steep high bank or in the walls of a landslip, and it is remarkable as to its architecture. The little bird excavates a long horizontal tunnel in the side of the bank, at the end of which is an oven-like cave, in which it builds its nest of vegetable fibre, roots, feathers and hair. The neighbours build so close together that the bank in many places appears to be completely honeycombed. These nests are built at least 12 inches from the surface of the bank. This bird visits the neighbouring streams and ponds in flocks, circling and darting here and there as is necessary in the pursuit of the winged water-insects. On its return in the spring it seeks and enlarges its old nest hole. It is widely distributed and occurs in great numbers.

The Sand Martin arrives in Great Britain often as early as the last week in March; it is also one of the first species to leave us. The Sparrows often oust whole little colonies of these birds from their dwellings, but when the colony is a large one they get the better of the hectoring intruders. As soon as the young are able to leave the nest they go to spots where there is water, as they find their food all day long in localities where there is an abundance of insects-gnats especially. Most useful they are in marshy localities, where the atmos- 
USEFUL.

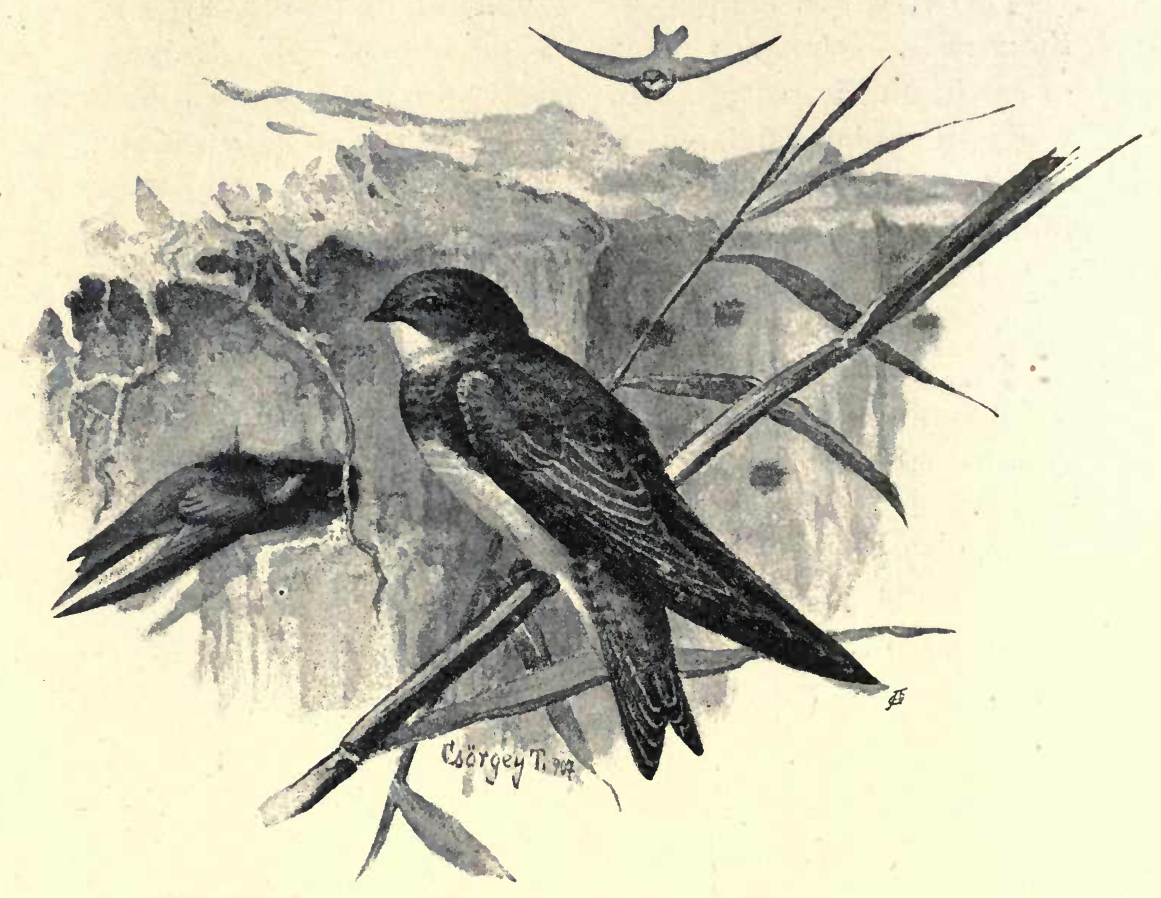

THE SAND MARTIN. 
phere would be intolerable for human beings but for the work of these little creatures. A little dry grass and a quantity of feathers supplies material for the nest which, being in a little chamber up a tunnel, out of the disinfecting wind, gets flea-infested and very unpleasant. Railway cuttings are much frequented both by Martins and Wagtails because the passing of a train stirs up insect life in it.

The gnat is frightfully prolific; it would soon poison our water as well as render it hard for men to breathe. A mother gnat is said to lay from 200 to 300 eggs at one time, and in two weeks the young from these are able to lay eggs themselves. Gnats must themselves be needed in the economy of nature, but if not kept in check they would render our life absolutely unbearable; they form the food for fishes, however, as well as for birds.

A porter at a railway station close to a cutting told Mr. C. Simeon, who wrote on angling and natural history, that they did not allow boys about, robbing the eggs in the colonies nesting there. "They"-the birds - "are such good friends to us that we won't let anyone meddle with them." He explained further that the flies about the station would be unbearable but for the Martins that were always hawking about it. Before the Martins arrived a few warm spring days often brought out a troublesome number of flies. "Now," he concluded, "we may see a fly now and then, but that is all."

The Sand Martin is smaller than the others of the Swallow family and has dull simple coloured plumage. Back greyish brown, throat and underparts white, the short forked tail is of a uniform ashen-grey. Feet small but strong. It lays five small, pure white eggs. 


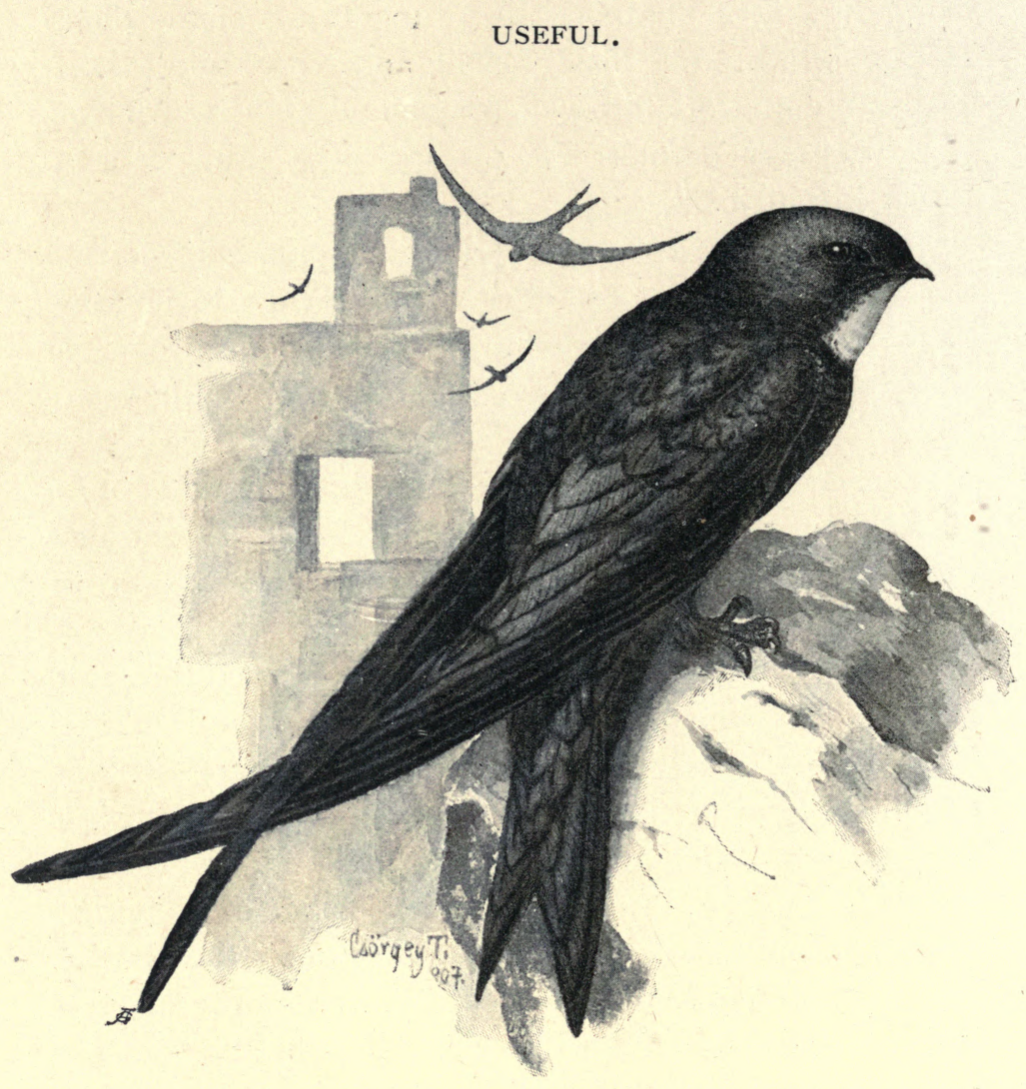

THE SWIFT. 


\section{The Swift.}

(Cypselus ápus.)

THE Swift comes to Hungary early in May and leaves again the first days of August. In England it comes and leaves about the end of these months, that is as soon as the young are ready to fly. The materials for the nest are obtained on the wing, therefore often with difficulty, as the wind brings it. These are glued together by the viscous secretions of the bird. Sometimes, however, it robs Martins, House-Sparrows and Starlings of their homes. The wild note of see-see has gained for the Swifts the name of "Screechers," and "Devilings" in Great Britain. They always hunt in companies and one might say that they compass the wide world in their rapid and powerful flight. The feet which are so helpless on the ground are well adapted to clinging on to the rocks and heights where they breed. The work Swifts do in clearing the air of insects must be enormous, these forming all their food.

This is one of the most interesting of our British birds, and one that is still an unknown quantity, in some respects, to the most learned of our ornithologists. " It soars on higher wing" even than the Skylark. A larger bird, it rises until it is lost to the keenest sight, remaining in the air longer, also, than perhaps any other bird. Whether it is capable of rising from the ground, when once there, is, curiously enough, still a matter of dispute among certain naturalists. "Can Swifts take wing from the ground?" was a question raised not long ago in "Nature Notes," the organ of the Selborne Society. 
Over two centuries ago Dr. Plot wrote of the Swift, ". . . it having so very long, wings, and so short legs and small feet, that it cannot easily rise from the ground unless it be very plain and free from grass; wherefore it either always flies or sits on the tops of churches, towers, or else hangs on other ancient buildings by its sharp claws, from which it falls and so takes its flight." It would appear from old records to be very much commoner now in our country than it was; and several recent accounts attest to its trick of exploring the old nesting-hole of a Starling. Mr. Yates, of Staffordshire, and Mr. Carr-Ellison, of Alnwick, both give interesting facts in corroboration of this proclivity. In an Eccleshall street Mr. Yates saw a Swift enter a hole where it had been in the habit of nesting, but it quickly emerged with a Starling fast to its tail. So weighted, the unlucky Swift soon came to the ground and to grief, but it was rescued and was started on its flight again. The Alnwick naturalist, again, saw a Starling pecking at a grounded Swift, and drove the former away. The Starling then flew on to an apple espalier close by, and watched the Swift, which tried to fly along the slightly sloping walk, but it could not get its wings clear of the ground. Its friend lifted and threw it up in the air. Three times this gentleman has witnessed the same scene at long intervals. The reason of it is that he had had a hole made near his study window for nesting purposes. Starlings always build in this in April or early in May, and after they have left Swifts build in the same hole. Sometimes they attempt this too soon; one comes to explore the hole, and gets caught by a returning Starling who at once pulls it to the ground below, where it is pecked whenever it tries to move. The Swift never 


\section{THE SWIFT}

alights on the ground of its own free will; about eighty of these birds, which were picked up dead on a peninsula where I once sojourned, had dropped, exhausted by violent storms encountered on the migratory flight, and there for want of food and help they had perished.

It is a delight to watch the evolutions of a Swift on a clear evening; with a grand, falcon-like stooping, the cock-bird begins to drive its mate back to her nest; at least, such is supposed to be its intention. The males first rise high in the air, and then make the swoop, and there is much evading by the females, and renewed pursuit, after which the males come back alone to enjoy themselves whilst their mates sit quietly on their nests.

The Swift, which used to be classed with Swallows, is now placed in the same order as the Fern Owl or Goatsucker, being, it is decided by scientific authorities, more allied to the latter in its structural affinity than to the Swallow. Its general colour is a bronzed blackishbrown; the throat is a greyish-white; the bill, claws and toes are black. The young birds have more white about the throat than the adults. The tail is forked, the wings are long and narrow, formed like a sickle. The eggs are generally only two in number, oval in shape and dead white, whereas the Swallows and the Martins lay four to six eggs each. Also the Swift has only one brood in the season, instead of two. 


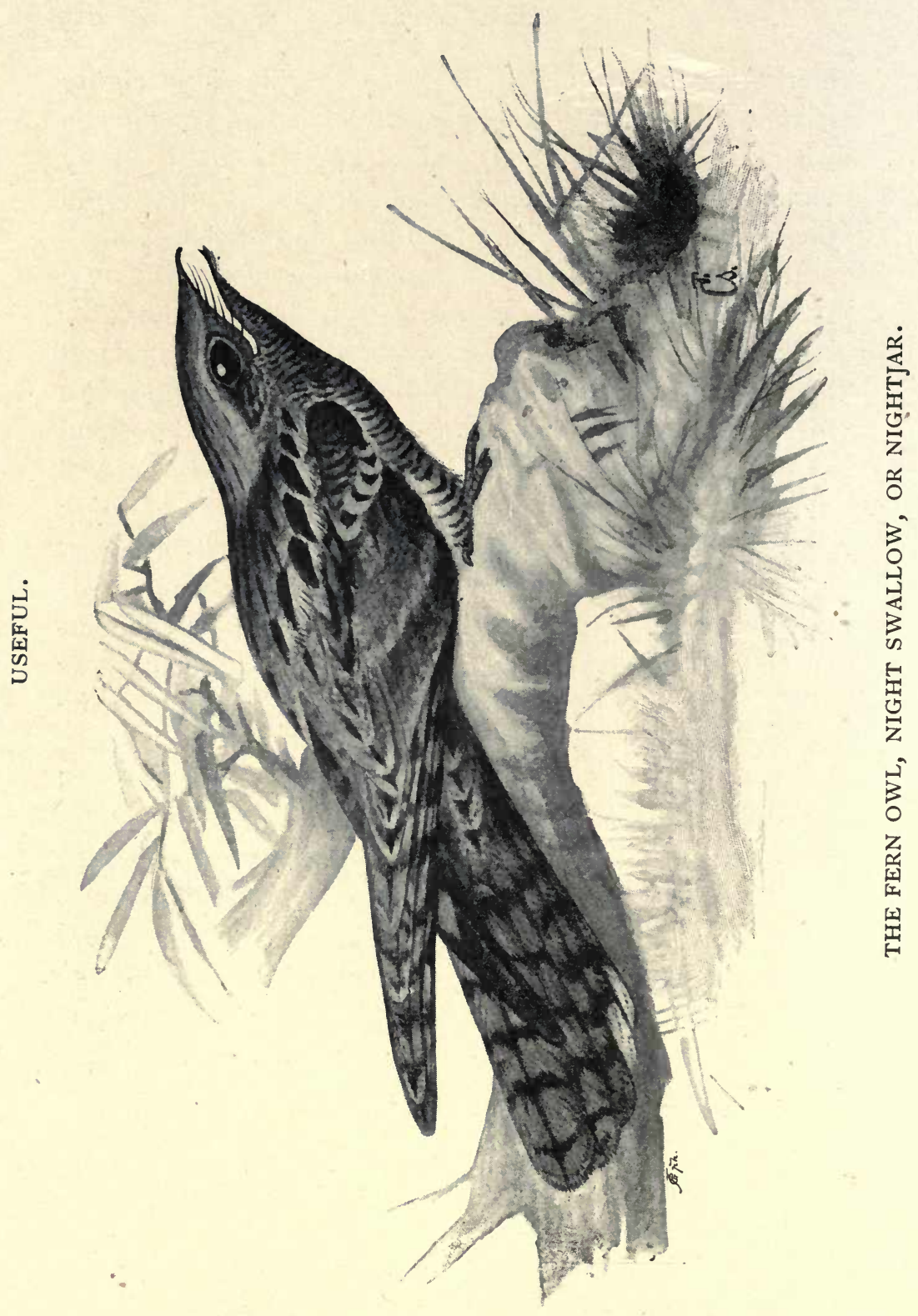




\section{The Nightjar. \\ (Caprimulgus Europaus.)}

THE Nightjar is the bird of twilight and late evening. When the sun has set and twilight is spreading over the land the bird leaves its day hiding place, on the bough of an old tree, where it has clung the whole time, undistinguishable from the bough on account of the colour of its plumage. It rises on the wing, and with its peculiar, irresolute flight, makes for the plain, or the bare places, and clearings in the woods.

Like the Swallow it catches its prey on the wing-the flying insects of the dusk, among them the largest night moths. Its cry is a pleasant faint "Häit, häit."

There is a wide-spread, foolish superstition that the Nightjar sucks the milk of cows and goats; it is, indeed, known to many people under the name of "Goat Sucker." This has arisen from the fact that it is often seen flying about, here and there, in the pasture fields. It darts down, then flies up again and seems to glance stealthily around. This behaviour, and its great mouth, have given it a bad name. Every herdsman, and indeed every one else who uses his eyes, knows that the droppings of cows simply swarm with insects towards evening, The Nightjar knows this also, and it is for that reason that the innocent bird frequents such places.

It is very useful and deserves help and protection, and the more so because it is somewhat rare in Hungary.

In the middle of May the Fern Owl or Nightjar arrives in Great Britain, and utters his jarring or churring 
spinning-wheel song over the sloping ground of many a common, where the golden gorse blossoms give out their delicious, apricot-like scent, hanging over rifts in the sandstone; and the ground below is studded with patches of ling, below which again luxuriant green ferns, having their roots in the cool moist bottoms, raise their tall fronds. It is warm on the bare patches of stony, sandy soil, on which the sun has been shining all the afternoon, and moths with other winged insects are here in numbers. The Fern Owls know that, and they are churring and squeaking over the slopes and tumbling and darting about after their winged prey, flying quite near to you as you rest on a bit of their hunting ground.

On a bare spot on the sunny slope, where a few gorse needles and bits of dead bracken lie, two oblong creamy white eggs will be laid later, marbled and veined in such tones as match their surroundings of stones, dead leaves and bits of brown fern-stalk, so closely that it is by a rare chance that the eye distinguishes them. And when the little creatures are hatched out, they will look, at first, just like a bit of lichen covered stone and a dead leaf. The mother will, it is said, pick her eggs up and place them elsewhere if an intruder has approached them too closely. When the young birds begin to flutter with their wings, the parent bird shifts them up by easy stages, through the low growth of heather and ferns, hustling them on, and bearing them up, until they reach the lowest branches of some dipping oak bough, where they sit in a line with the branch they rest on, invisible to the ordinary observer; and there they are fed with scarcely a pause in the flight of the industrious parent. In'Devonshire they feed much on "fern-web "-namely, small chafers. 
It is a curious thing that the unjust appellation of " goat sucker," given from time immemorial to this bird, has its equivalent in almost every country of Europe. It is like the case of the barn-owl, which is called "oil drinker" in the south of France. Night-feeding birds have always been the objects of ignorant persecution. The Nightjar is called tette chèvre in France and Geissmelker in Germany. Crapaud-volant is another of its names, after the toad, which is also said to suck goat's milk.

The Nightjar is about ro inches in length. It is a peculiar bird. The plumage is fine and soft; in this, as well as in its colour, reminding us of the Owl, with this difference, that the yellow in the colouring of the Owl is not so pronounced and the ashen-grey and washed-out looking brown is therefore more decided. The two middle tail feathers are a beautiful grev with dark dots and intermittent cross-stripes. The head is large, the eyes dark-brown and large, and they have power to see clearly in the twilight. The beak is small, the gape, on the other hand, relatively enormous, forming a yawning abyss when open; the edge of the upper mandible beset with moveable bristles. Legs short and weak. It does not build a nest. It lays two eggs on the bare ground and there hatches them. The eggs are nearly white with dark marble-like veining. 


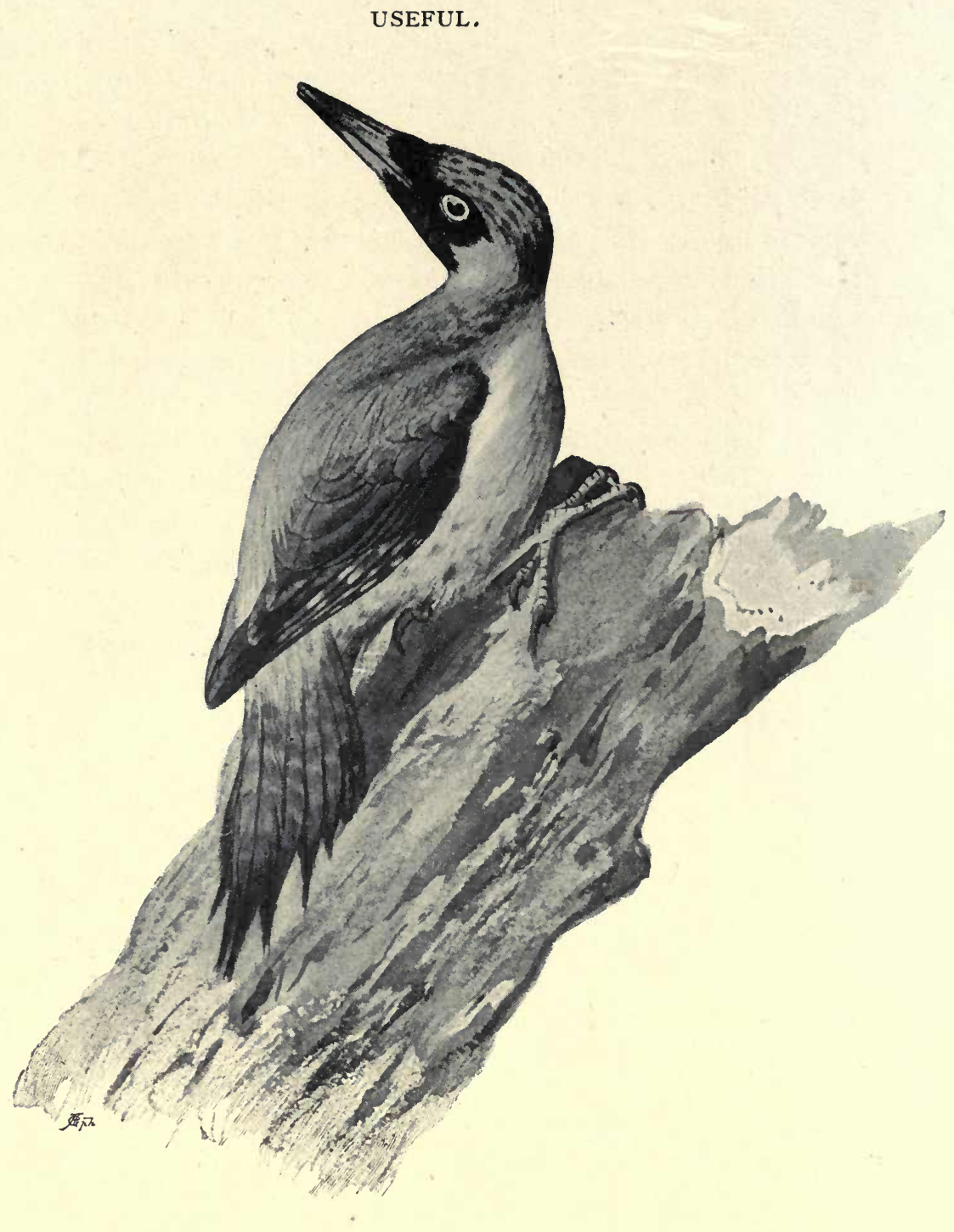

$\because$ THE GREEN WOODPECKER. 


\section{The Green Woodpecker. (Gecinus viridis.)}

THIs Woodpecker is indefatigible in its work of hacking trees and dragging out worms; it flies in a curve from tree to tree, always beginning its climb from the bottom; finds out the weak places in the tree, in which it pecks holes so that it can reach the insects in them with its long tongue, and so furnish itself with a meal. It is equally busy on the ground, with the ant-heaps, which it bores into. Then when the ants collect together it flings out its long sticky tongue; the ants are caught on it, as on a lime twig, and so they find their way in to the stomach of the bird. The Woodpecker carries on this business also in winter, when he breaks through the hard frozen side of the ant-hill, and surprises and decimates the inhabitants while in their winter sleep.

It is a noisy bird whose " $k l u-k l u-k l u-k l u$ " echoes through the wood, breaking in on many a lonely hour for the woodman; a real blessing in the orchard, and a skilful surgeon for invalid trees; on that account it deserves protection and care.

In this country it is fairly common.

This is the largest and best known of our English Woodpeckers, and it occurs in most of our wooded districts south of Derbyshire and Yorkshire. In the northern counties it only breeds occasionally. In Scotland it is little known and from Ireland it is also practically absent. In England, too, it is very local in its occurrences. The song which roused my imagination most in childhood's days was that one with the refrain about 
"The woodpecker tapping the hollow beech tree." And the fact that as I listened to it I could only gaze out of the old-fashioned bow windows of a town house, which looked out over a sloping expanse of smoky chimneys, made the idea of the Woodpecker tapping mysteriously suggestive and attractive. Since then I have heard it in many a country - the green species and its relatives, and the song takes me always back to the old home and the mother's side by the piano.

Windy March found me one morning in a pleasant wooded district in Suffolk. Above the tossing of the branches of the great elms, as the gale rushed over, sounded the notes of the Mistle-Thrush, fitly named the storm-cock, singing out his defiance to the weather, as he swayed on the topmost bough of an old cedar across the lawn. He is one of the earliest heralds of spring, and is never daunted by the weather, though it revert to wintry wildness. On the same lawn, well kept though it be, if we look out early enough, we may see a pair of Green Woodpeckers. Last evening, when for a time all was hushed and still, the well-known yiking laugh of the Yaffil, as Chaucer called him, came overfrom the avenue, whence, too, had sounded his busy drumming. Then he and his mate were busy getting the grubs that had bored deep down in the timber, but now come up near the bark of the trees in order to get the warmth necessary for their development. In the early morning hours, when the watchful gardener has not yet appeared, the pair tear holes in his well-tended lawns with their feet, and hack at the turf with strong bills to get at the grubs below. They feed indeed largely on ground grubs throughout the year, as well as on ants in summer, and timber-haunting grubs and beetles. 
The Lesser Spotted species, althougn not so widely distributed, is even more common in the south of England, and near London. One was shot lately in Scotland, as " a very rare bird." It is probably chiefly owing to the cutting down of old forests that they are not found in Scotland. Now and again they may even be seen in Kensington Gardens.

We have no picture of the Lesser Spotted Woodpecker (Dendrocopus minor). It is perhaps oftener present with us than is supposed, being smaller than its relatives. Also it frequents taller trees. I have seen numbers of these bright busy creatures in Hungary, in the poplars, along the river Waag, in the foothills of the Carpathians. Its colouring is much the same as the Greater Spotted species, only the markings are different and it is only just over five inches in length, whereas its near congener is just over nine inches. The male bird makes the same loud vibrating noise in the trees as the latter.

The Green Woodpecker is 12 inches in length. The mantle is bright olive-green. The crown of the male bird, as far down as the nape, is fiery red, also the moustaches. The lores and cheeks black, is less crimson on the head of the female, and the moustaches are black. The outer feathers of the wing are nearly black with white flecks. It has two front and two back toes; the claws, strong, curved and adapted for clinging. The tail feathers strong and suitable for pressing. Beak leaden-grey, strong, with an edge like an adze; worm shaped tongue which can be greatly extended. Having selected a suitable tree, it makes its nest hole at a medium height, with a narrow entrance and lays in it sixsometimes, but rarely-eight dazzling snow white eggs. 


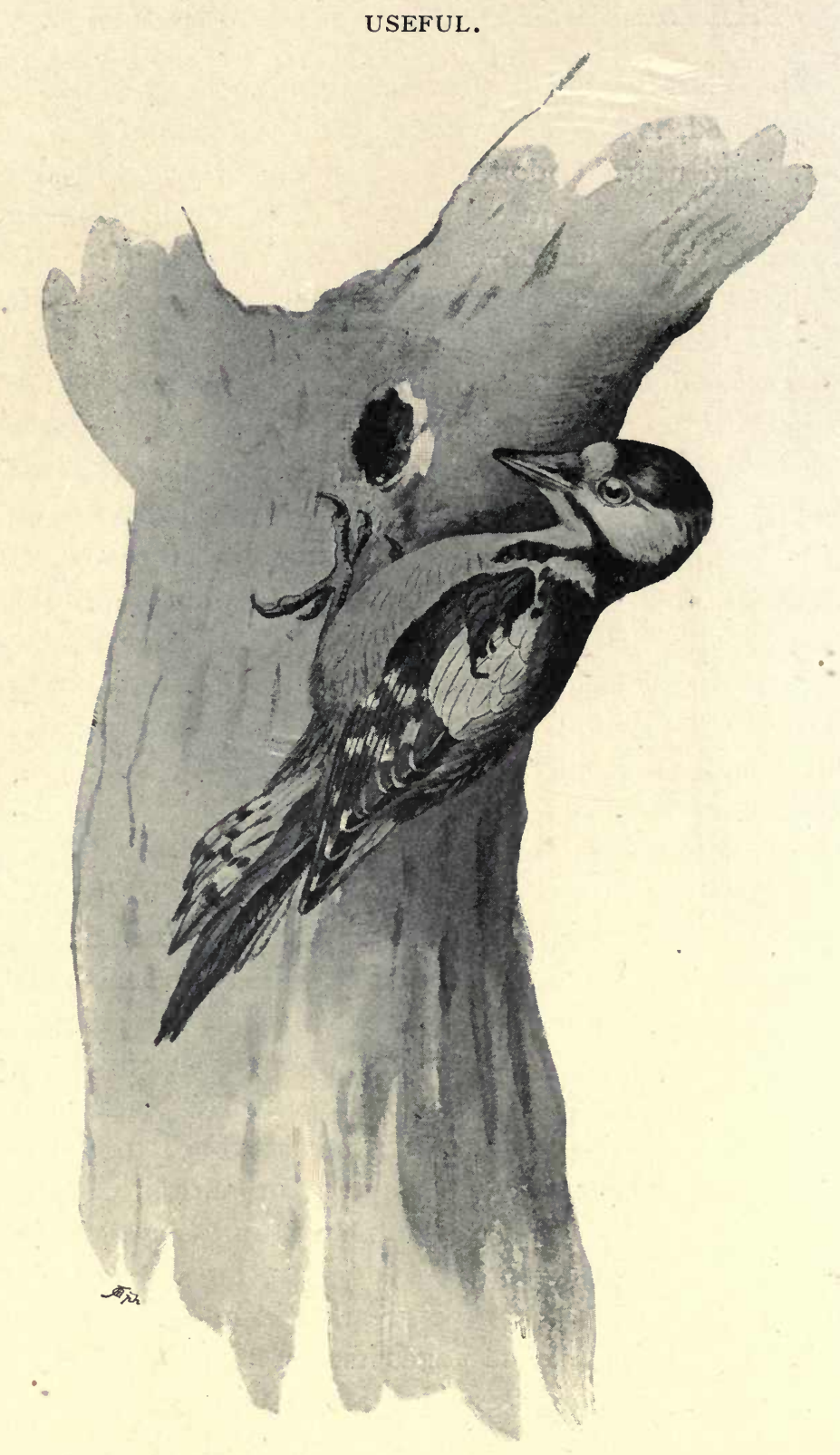

THE GREATER SPOTTED WOODPECKER. 
The Greater Spotted Woodpecker.

\section{(Dendrocopus major.)}

This also is a busy hammering bird, which flies energetically about the woods and gardens, climbing up the trees from the bottom, closely examining the bark and wood for grubs and bark-beetles, and extracting them with its long pointed tongue. When opportunity offers, it also attacks oily seeds, such as those of the sunflower and berries; but this must not be counted as harmful. By its whole nature, and its peculiar work it belongs decidedly to the most useful of birds. There is a widely spread belief and suspicion among the country people that this Woodpecker spoils the healthy trees, but its beak cannot avail beyond a certain degree of hardness; it can only pierce holes where the wood is softened by rot, and therefore harbours timber grubs. The fine wood-dust under the trees where the Woodpecker has been at work calls the attention of the good gardener to the bad state of the tree, and he can then take steps to arrest the mischief if not too late. The Spotted Woodpecker can conceal itself very quickly. When it sees a human being it clambers up the opposite side of the tree trunk. In autumn it roams about with swarms of other tree-cleansing birds. In spring it makes a loud drumming noise among the dry branches.

It is fairly common in Hungary, but is less so in Great Britain, although pretty well distributed in the wooded portions of England. In Scotland generally it is rare, but southwards from the Shetlands, down to the east coast, it occurs at times on migratory flight. 


\section{I30 THE GREATER SPOTTED WOODPECKER}

THIs is a black, white, and fiery-red speckled bird, length over nine inches. The black lores extend like a bridle to the neck. Back and rump black. In the male the back part of the head is red, in the female black; in both the lower part a burning red. The sides of the underparts dingy white; on the shoulder a white spot; on the flight feathers white, cross flecks. Tail strong, the middle feathers pointed and stiff, suitable for climbing. Beak relatively short, but strong at the base, pointed like a chisel. It bores its nesting hole in trees about half way up, the entrance being round and only just large enough for the bird to go in and out. It lays four eggs, occasionally six, of a dazzling snow white, with delicate shells. 


\section{The Tree Creeper.}

- (Certhia familiaris.)

The winsome little Tree-Creeper is distributed all over Great Britain, but you need a sharp eye to detect it in its quiet colouring on the trunk of a tree with which its quiet colours are in perfect harmony. Within the crevices of the bark it finds it diet of destructive creatures' eggs which are glued to the bark and little spiders which hide there. During the winter it associates with the Titmice and Fire-crested Wrens. Upwards and downwards and round about the old tree trunk it moves. It might be taken for a mouse or some such creature; it moves about so deftly and so close to the bole of its tree, a useful unobtrusive little bird. In the United States they consider this species so useful that they fix a box for it, to entice it to nest in gardens.

The Tree-Creeper climbs as nimbly as the best Woodpecker. It cannot extend its tongue as that bird does, but can use it very cleverly. With its fine little bill it can pierce into the smallest crevices and extract from them the tiniest grubs. It is of great use in wood and garden. Its usual note is a low "seet" or "seet, seet, seet." The simple song of the male bird is recognisable by the syllabes teet, teet, teet, titi-woi-teet.

It is not uncommon in Hungary.

The Tree Creeper is smaller even than the Wren, but is longer than that bird; it is a tiny creature with a stiff tail which is very useful in climbing. There are three front toes and one back toe on the little legs; the 


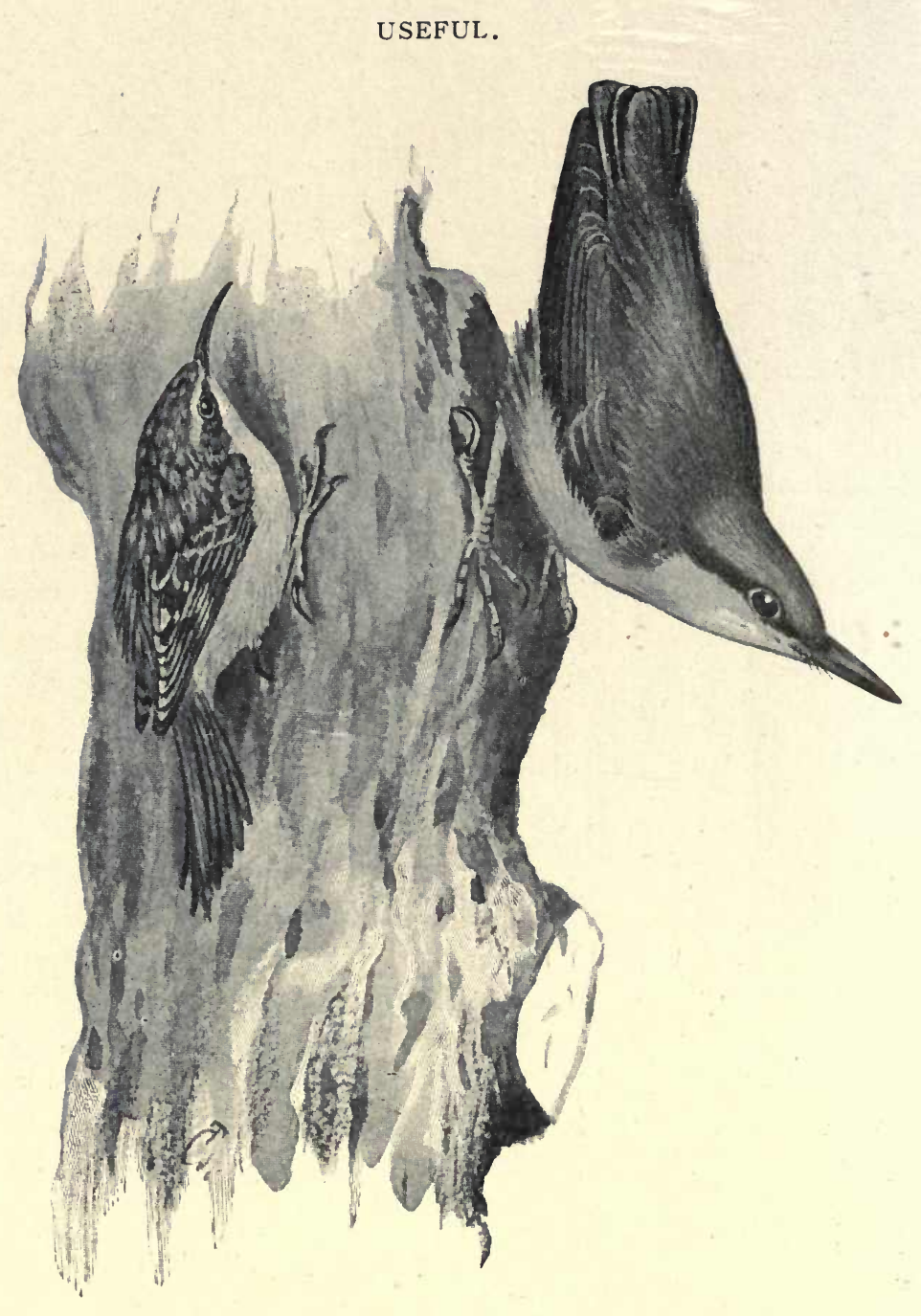

TREE CREEPER AND NUTHATCH.

$\cdot$ 
bill is delicate and slightly curved; the upperside of the body is the same grey of the tree trunks, spotted with white. It lays five--sometimes as many as nine-milkwhite eggs, delicately speckled with rust-red and bloodred spots. The nest is made in crevices, small holes, sometimes between the loosened bark and the tree, and is composed of fine soft material.

\section{The Nuthatch.}

\section{(Sitta casia.)}

Wherever in wood or garden the Nuthatch dwells its voice is heard. It calls sometimes a flute-like " tiïi, tiiii tiïi "-sometimes a quick "kwee, kwee, kwee" - and it is always very busy. It is the only bird we have that can climb head downwards and that as quickly as it is safe. The beak is strong and pointed. It picks out of crevices and from under the bark of trees everything that is there in the way of grubs and beetles and insect eggs. In the autumn it gets at oily seeds, conceals nuts and filberts in suitable crevices and knocks them till they crack. It does the same with the gall-nuts in order to get at the maggots or chrysalis of the gall-wasp. It is an absolutely useful bird and one not uncommon with us in Hungary.

This bird is common in most districts in the centre and south-east of England where there is old timber. In the westward it is less common. In some old parks in Yorkshire it appears again, but is rare elsewhere in the northern counties. In Scotland it is not very often 
seen and in Ireland it is so far unknown. Beech-mast it is fond of in our own woods, but it feeds on insects on the ground as well as in the trees. This species, like the last-mentioned, is very mouse-like in its movements and many ornithologists assert that it sleeps with the head and back downwards.

The Nuthatch is as big as a Sparrow, but more solid; above bluish-grey; underneath white or rust-red; over the eye a black stripe. The tail is not adapted for climbing. Legs short and strong, claws strong and sickle-shaped, three toes turn to the front, one to the back. The clutch consits of six or eight white eggs, speckled with rust-red. The nest is formed of a wide hole, which so walled in by the bird with earth and clay that there is only just room for it to go in and out. 


\section{The Crossbill.}

\section{(Loxia curvirostra.)}

The Crossbill is a stationary bird as to habitat, but it does ramble about. Staying at home, or wandering, depends upon the supply of sap or seeds of the fir tree, which forms its sole food; although it visits also beeches, maples, and alders, sometimes even falls back on thistle-seeds, and does not even despise caterpillars. Its beak is an excellent tool for removing husks and crushing seed. It wastes a great many seeds, for it lets fall all those which it cannot shell with one bite. It reminds us of the Parrot, not only by the form of its beak, but also by the clever way in which the beak is used in addition to the legs in climbing from bough to bough, just as the Parrot does. It is besides a cheerful, indeed, a restless bird. It sings whole songs, and the old bird fancier Bechstein has put words to one of these, beginning :-

\section{Zeri-zeri doeng-doeng-doeng-hist-hist.}

Its call is sok, sok.

The firwoods of our Hungarian mountains contain plenty of these birds.

These interesting birds, the Crossbills, nest in many parts north of the Solway, and southwards may be seen in September in flocks or parties, wandering about in suitable districts in search of food. In the young birds, the bill, or rather the mandibles, are not crossed, and the beautiful crimson colour in the male is not seen the first year. A greenish-orange replaces this in the 


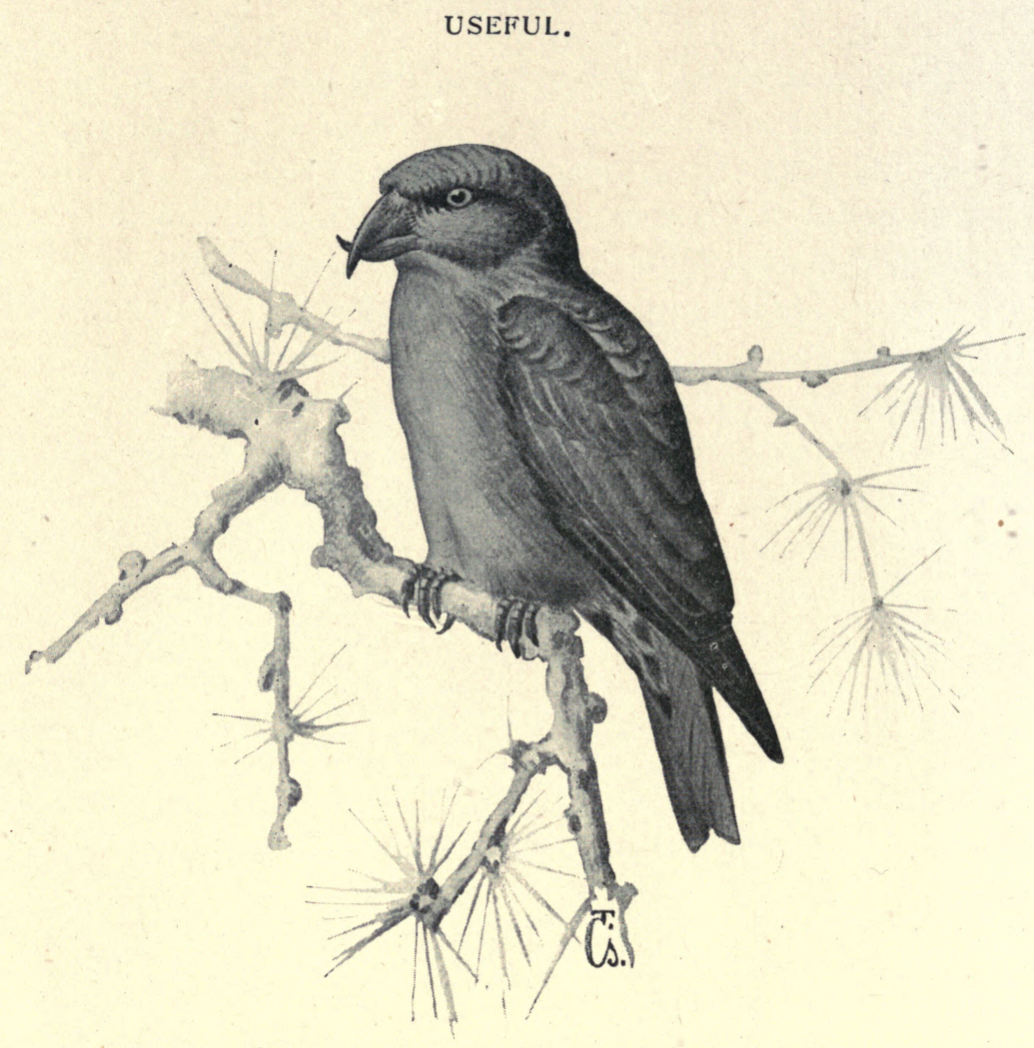

THE CROSSBILI. 
females. I saw a very fine Crossbill lately that had been obtained in the valley between Newbury and Theale, where these birds are to be found most years among the fir-clumps on the higher lying commons. It is said to breed in many of the Southern Counties, but there is no reliable evidence of its doing so in the Midlands. In Scotland it nests in districts where are old pine forests, building a cup-shaped structure of dry grass, moss, and wool, which is placed on twigs, and these on the branch of a fir, close to the stem. From fir-cones their food is extracted, but in the autumn, berries and apple pips are taken, an old náme for the Crossbill being Shell-apple. Many years ago great damage was done to some apple orchards by the boring of fruit to extract the pips.

Although usually a winter visitant, the late Lord Lilford reported having seen large numbers of these birds during the month of June in a district of North Devon. The forest-folk of Thuringia are fond of them as caged pets, considering that they bring luck to the house, and also cure the diseases of the family-if the mandibles cross left to right, those of the females, if from right to left, those of the males. I would not now keep any bird in a cage, but I once kept many; and the most amusing of all these was a Crossbill, who had a large wired-off compartment to himself, between one containing a number of avadavats, and another inhabited by Redpoles, Siskins and other birds. He loved to tear open the shells of almonds to get ${ }^{\circ}$ at the nuts. When the little avadavats had gone to sleep, nestling together for warmth, the old Crossbill would sidle up, looking very wicked, and quickly lift the end of their perch. Down fell the small things, master Crossbill watching them with unmistakable delight. At last he made so 
much commotion amongst the lesser birds that we made a present of him to Mr. Denham Jordan, who wrote an amusing memoir of him which was headed "Crossbill Turk."

The Crossbill is 6.5 inches in length. The back and underparts of the old male bird are red, the rump fiery red; wings and tail dark olive-brown; the back of the female is grey, rump greenish-yellow. The upper beak is curved downwards, the under one upwards, inclined to one side, with sharp points. The tips of the beaks cross, sometimes to the right, sometimes to the left. This crossing of the two halves of the beak is the exclusive characteristic of this bird. It lays three to five greyishwhite eggs spotted with shades of reddish-brown. The nest is found in fir trees, and sometimes in the birch. It is made of fine materials, is built very high up, and is well concealed. It nests in February. The nest therefore is very stout and well-lined, and the mother-bird sits continuously in order to preserve the warmth. 
CHAP'TER V.

\title{
SUMMER WORKERS.
}

\author{
The Wryneck. \\ (Iynx torquilla.)
}

The Wryneck is a migrant, which makes itself heard as soon as it appears with its Kyen-kyen-kyen or pay, pay, pay, which is as peculiar as it is pleasing. It cannot be denied, that after the long silence of winter the sound is a very agreeable one. The Wryneck does not tap and climb like the Woodpecker, but it uses its tongue in the same way. Ants cling to its sticky tongue. It drags out and destroys the insects from the crevices in the bark of the trees. On this account it is useful.

It is not shy and can be observed quite close by. It owes its name to its peculiar position when it stretches. out its neck and twists it round, raising its crest and spreading out its tail. It likes trees with dense foliage, and orchards.

In England we call this bird the Cuckoo's mate or leader, because it always precedes the coming of that bird by a few days. This name has its equivalent in several European languages. It is more common in the south-east than in the west, and is rare in Wales. Some northern counties it never visits, yet from time to time it strays up as far as the Orkneys and the Shetlands. Towards the end of September it leaves us for the south. In autumn it is said to eat the berries of the elder, otherwise its food consists entirely of insects, ants and their 
USEFUL.

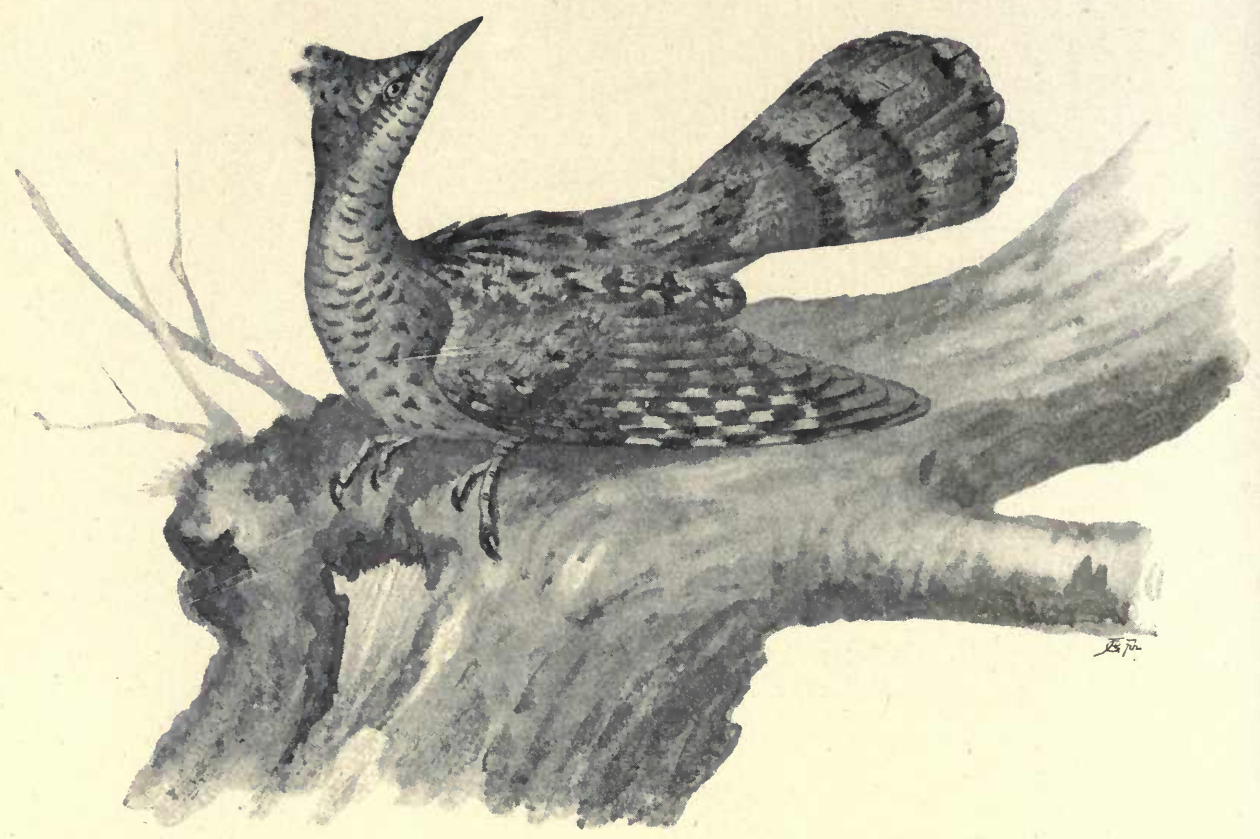

THE WRYNECK. 
pupæ especially. It is very courageous in defence of its young and will hiss like a snake if an enemy or intruder approaches its nest.

Country children in our Home Counties listen eagerly for the call of the Cuckoo's mate, whom Eliza Cook calls " the merry pee bird." They know then that Spring is with us, and out-door pleasures are on the way. It is only the size of a lark, and it is difficult to observe the bird well either on its nest or during its short undulating flight.

The Wryneck is seven inches in length. It has fine, loose plumage, which recalls that of the Owl or the Night-jar. The throat is clay-colour with fine dark wavy cross lines; tail a beautiful grey with delicate black speckles, and six broad pointed stripes across it; the under side is covered with brownish-white and black spots, and delicately speckled : from the nape, down the back, about the shoulders, are large black spots. The flight-feathers have rust-red cross stripes; it has two toes towards the front and two towards the back; the legs are short. It makes its nest in any cavity it can find, and in it lays, on soft chaff, its seven to twelve white eggs. The Wryneck, like the Woodpecker, has a long wormlike tongue which can be extended. 
USFFUL.

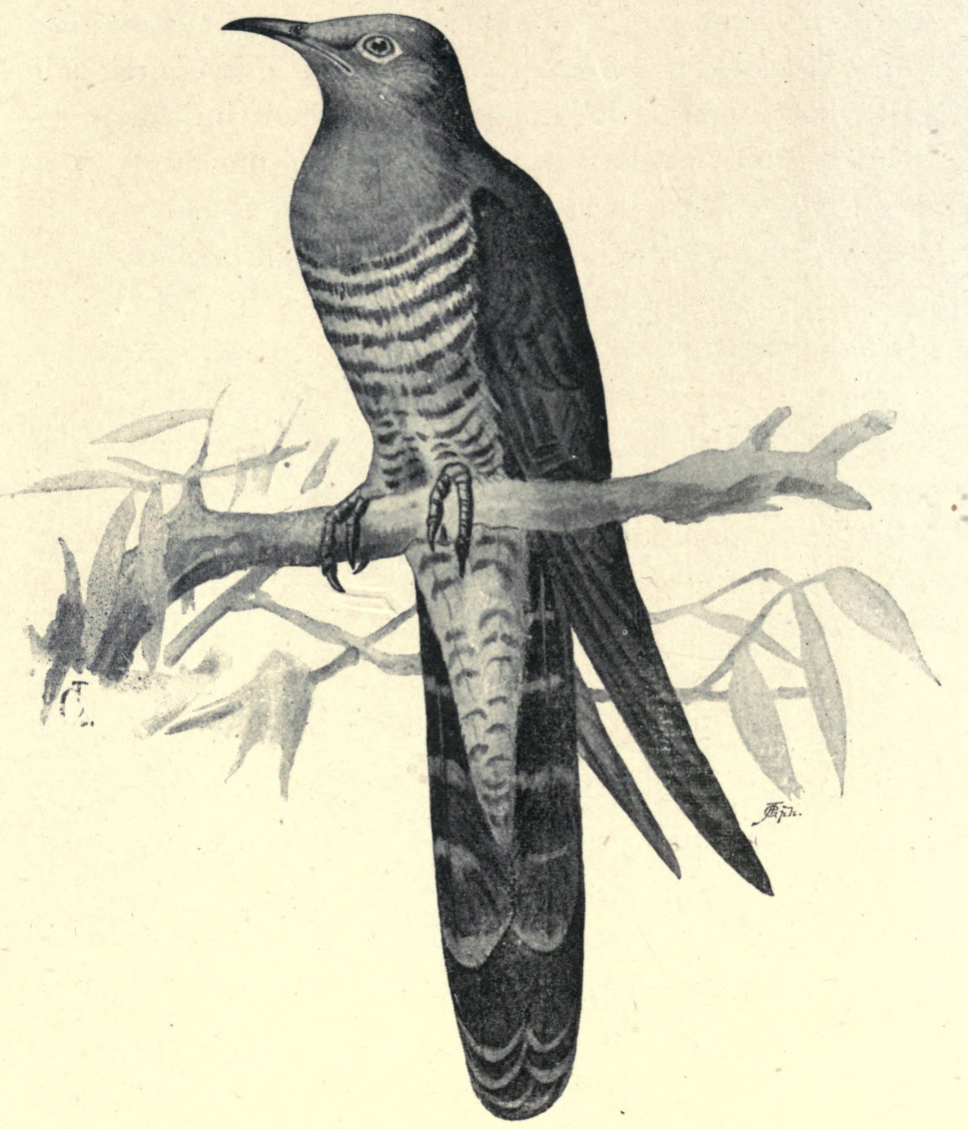

THE CUCKOO. 


\section{The Cuckoo.}

(Cuculus canorus.)

The Cuckoo is a most useful bird, as regards his food, which consists for the most part of very mischievous insects and caterpillars of all kinds; it is the more so as this bird is insatiable.

An individual Cuckoo probably always lays its eggs in the same neighbourhood, and always in the nest of the same kind of bird, and usually the same kind in which it was itself brought up. The young Cuckoo soon obtains the upper hand in the nest, on account of its rapid growth, and throws out its weaker fosterbrothers and sisters. It always calls its own namethough it sounds more like "ha-hu"; sometimes it utters sounds which are like laughter. There is a popular superstition that the Cuckoo foretells to those who ask it, how many years they will live-and to young maidens, how many years they must wait for a husband.

Like the Swallow it brings the announcement of spring, and our Hungarian children have a song:-

“ Cuckoo! Cuckoo! sounds from the wood Now let us dance and sing;

For Spring is coming ; Spring is here; ",

The Cuckoo detracts from its usefulness, however, by its other actions. It greatly damages the nests of the small useful birds, in which it places its eggs, and consequently its young ones. The female Cuckoo selects a district, finds out all the nests of Wren, Robin, White- 
throat, Wagtail, or some other, and thereupon begins to place her egg in this. When she finds that she cannot get into a nest of a bird which builds in a hole, she lays her egg on the ground, then takes it up in her bill and drops it into the nest.

In spring and summer the Cuckoo's note sounds all through Great Britain. Its ways will always have a fascination both for the old and the young. Many will be surprised to hear that scientists have now verified the placing of its eggs in the nests of as many as I 45 species; in different countries, that is, including the nests of the Isabelline and other Chats in Africa and China, and the Red-headed Bunting on the steppes of Turkestan. In Lapland the Grey-headed Wagtail and the Red-spotted Bluethroat are the foster-parents; in Andalusia the Great-spotted Cuckoo lays oftenest in the nest of the Spanish Magpie.* The old poet, Quarles, must have seen the bird with an egg in its beak when he wrote "The idle Cuckoo having made a feast of Sparrow's eggs, Lays down her own i' the nest."

A German authority, Dr. Rey, made a collection of over seven hundred Cuckoo's eggs; and he states that the proportion of those which resemble in colouring those of the foster-parents is only about thirty per cent. Yet out of sixty-seven which he took from a Redstart's nest fifty-seven were blue. Another collector again states that only one blue Cuckoo's egg had passed through his hands. Lately a man told me of having found two Cuckoo's eggs in one small nest, an unusual ocçurrence.",

* Mr. Wells Bladen, of Stone, wrote an interesting brochure on this subject. 
The Cuckoo is a very slender, long-tailed bird, I 2 inches in length. In the male bird the mantle is ashengrey, the tail has cross stripes, the under-parts are whitish with cross-running wavy lines. The female and young ones, with their reddish-brown dark cross bands, remind us of the Hawk. From this arises the popular superstition that the Cuckoo changes into a hawk in late autumn. The legs are yellow; eyes fiery red edged with yellow, beak dark, reddish at the corners. It never builds a nest. In its system of transplanting it shows itself an arrant knave, for it places its eggs in the nests of other birds, whose eggs, as a rule are totally different in size, colour and form. The eggs of one Cuckoo so placed may reach the number of 20 to 22 , but as a rule are about II to I2.

With regard to the Cuckoo's usual habit of leaving us in the autumn, a belated young bird may now and again spend the winter here. One frequented my sister's tennis ground till the end of November, when the cat caught and killed it; and a gentleman of my acquaintance, Mr. Robinson of Pinchbeck, Lincolnshire, saw one on his farm early in February of I908. 
USEFUL.

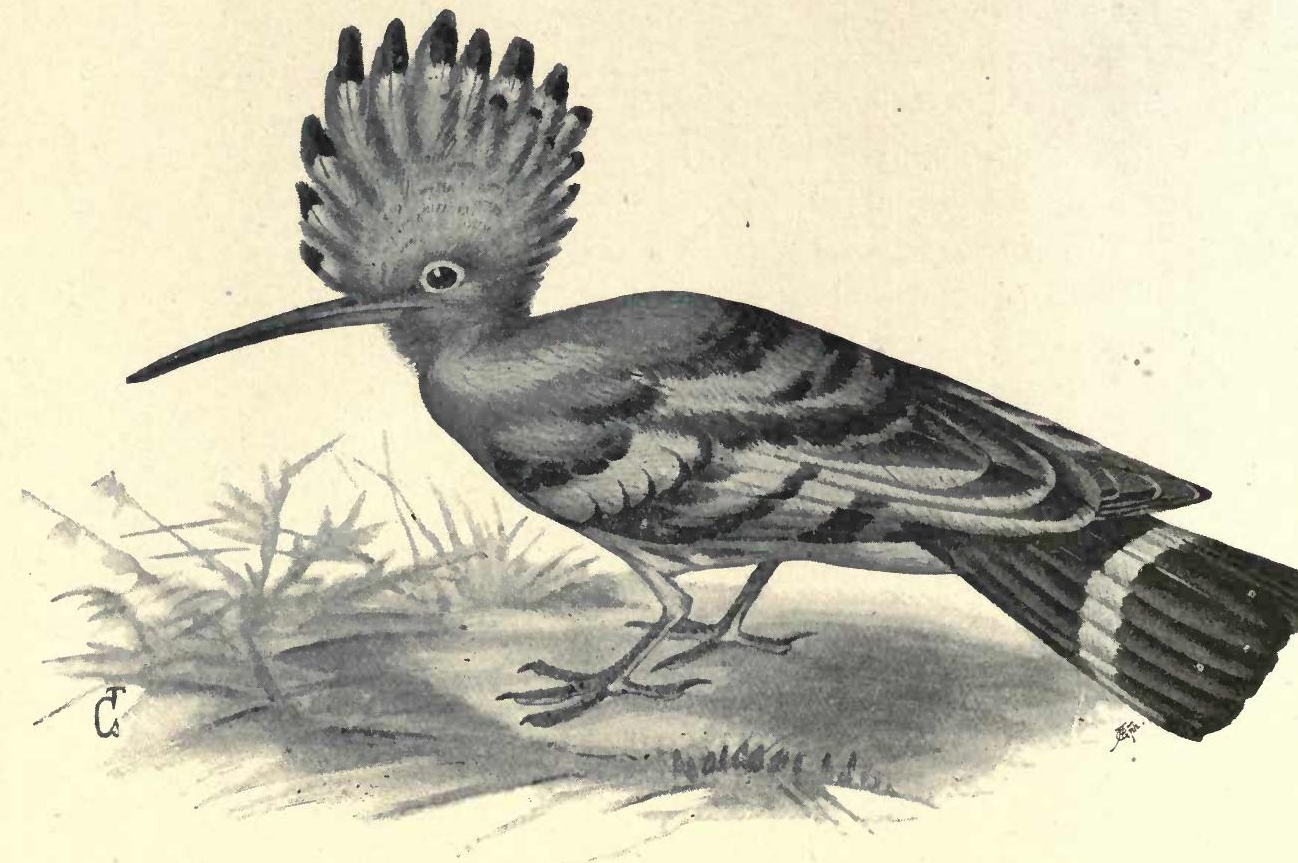

THE HOOPOE. 


\section{The Hoopoe. \\ (Upupa epops.)}

The Hoopoe is from base of bill Io inches long. It is a fair bird with beautiful variegated plumage. Head, upper back, and breast pale rust-red; mantle, shining black, with white ornamentation; tail also black, with a crescentshaped white band curving inwards towards the rump. The head is adorned with a bunch of feathers which the bird can erect or depress at pleasure. The feathers of this are light coloured, with black tips, but the tips of the longest feathers are black and white. Beak, long and slightly curved, thin, and adapted for picking. It lays four to seven eggs, greenish olive, or clay colour, but always of uniform colour, which it places on the mould in the holes of trees: The Hoopoe is the only bird that fouls its nest, and brings up its young in dirt and filth. On this account both mother and young have an evil odour, as some of the bird's names indicate.

This national Hungarian bird is a migrant, and dwells chiefly on the borders of woods in the low bushes, and in the neighbourhood of pastures, where it is never weary of examining the droppings of the cows, from which it obtains beetles and maggots. It also catches gnats on the wing, and the leaping grasshoppers. It is a noisy bird, and its cry "Hup up"-from which its name is derived-is heard sounding vigorously from the branches. It is one of our most useful, and most brilliantly coloured birds, and should be protected.

For over two hundred years the Hoopoe has been recorded as a visitor to Great Britain, a more or less fre- 
quent one. Some years ago the late Mr. Howard Saunders told us that the head-keeper at Ashburnham Park, in Sussex, destroyed seven in one week, and that many a one has been slain in Kent, at the point where they alight after crossing the Channel. A few have, in spite of persecution contrived to breed in our country-in southern counties chiefly. Sometimes numbers come to England in the autumn, and it is generally an annual visitor in small numbers to Ireland. As it is a useful bird all should try to procure protection for it. 


\section{The Great Grey Shrike.}

(Lanius excubitor.)

In spite of its comparatively small size this is a bold bird, and a true "Watchman"; he keeps a sharp lookout from the top branches of a dead tree, or a post, and will not suffer any other bird, even if ten times his size, to perch anywhere in his vicinity. Buzzards, Ravens, Crows, Magpies, he pounces on, something in the manner of a Falcon, and tries to push them off. $\mathrm{He}$ generally succeeds in routing the intruder, for he is indefatigable in attack. His food includes any living creature that he can slaughter.

He picks up a fat grasshopper, hovers over and darts on a mouse, just as a hawk does. These acts are beneficial; but they are not to be compared with the amount of harm he does, as a cut-throat and robber among the useful small birds. He disturbs the nests of the little singing birds which build on the ground, ransacks bushes and treetops, and slays mercilessly. His methods are those of the highwayman. He will sit on a stake on the top of a hayrick and watch, keeping perfectly still, only his eyes sweeping around. When his victim comes within range of his vision on earth, or tree, he instantly falls upon it. His close relation to the birds of prey, is indicated by his cry "Tett, tett." His call is a strong, rough sound, like, "Sheck, sheck," or a fainter "Truii." This bird remains in Hungary through the winter, but is not very common. Where he does take up his abode, he does great harm by slaughtering the useful birds. 
HARMFUL.

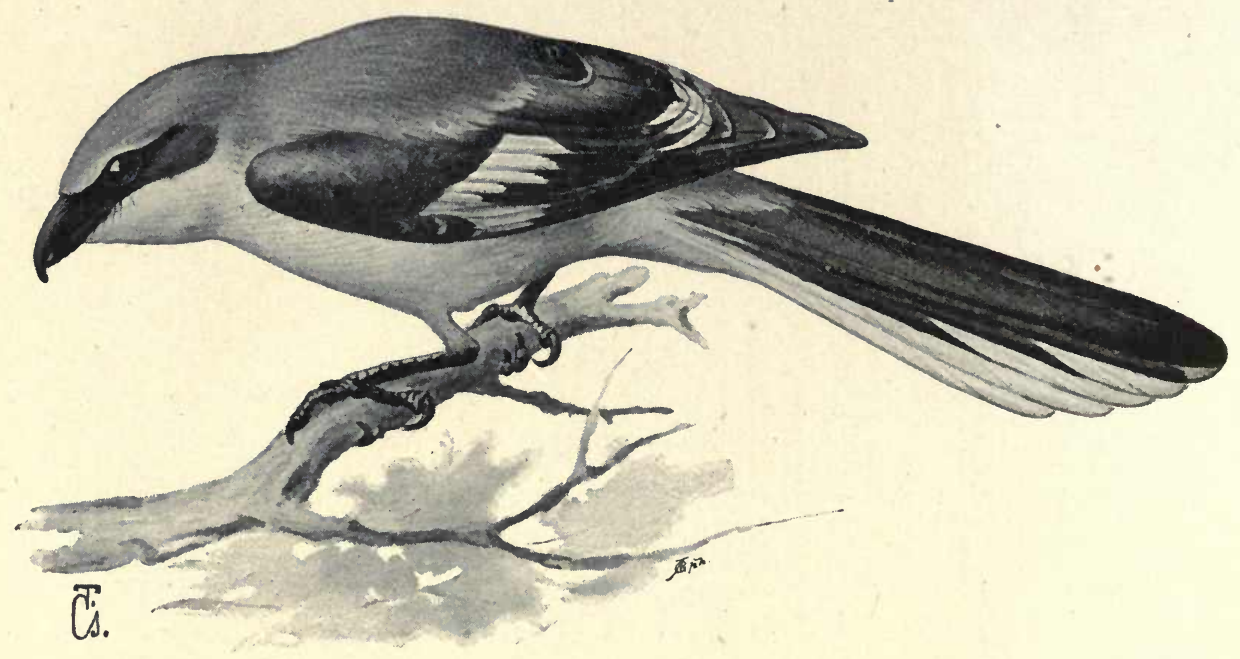

THE GREAT GREY SHRIKE. 
This Shrike is one of the regular visitors from the Continent, coming to Great Britain in autumn and winter. In England it has even been seen during the summer, but it has not bred with us. Lizards, mice, shrews, frogs, and insects, especially beetles and grasshoppers, it feeds on, as well as small birds.

The Great Grey Shrike is 9.5 inches in length. The back is light ashen-grey; underparts dingey white, brow whitish; from the base of the bill a broad black band passes over the eye to near the ear. Bill, legs, wings and tail black : the wings, however, have a white patch, and also the feathers on both sides of the tail show a white border. On the underparts of the female bird, faint stripes of a darker shade are discernible. The bill is indented at the point and has a hook. The bird builds its nest in trees and lays five or six eggs, occasionally seven, greenish-white speckled with grey.

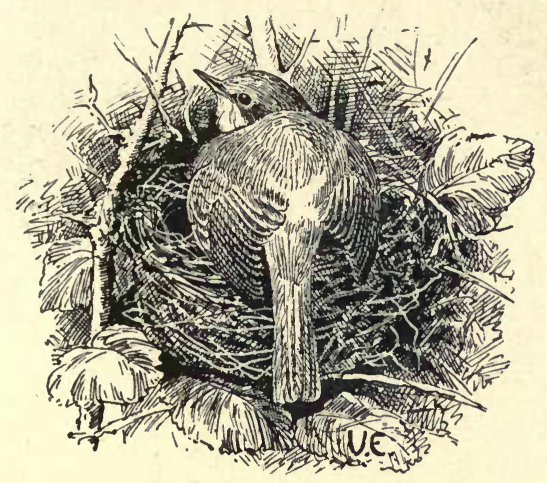

A Watchful Mother. 


\section{USEFUL.}

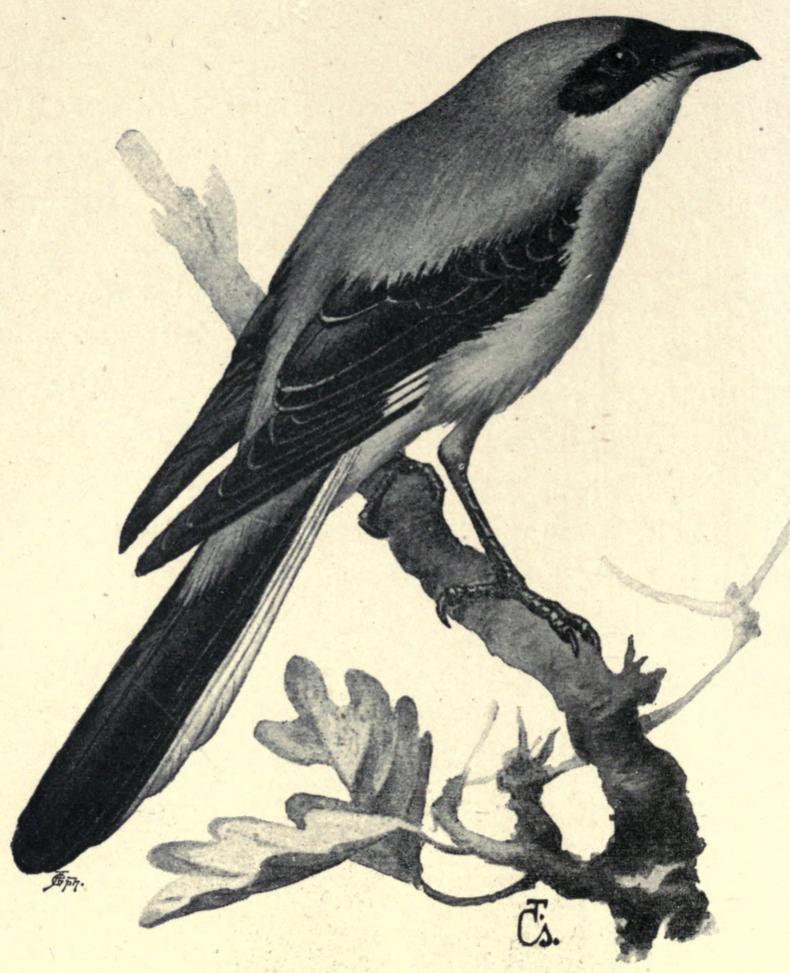

THE LESSER GREY SHRIKE. 


\section{The Lesser Grey Shrike.}

\section{(Lanius minor.)}

The habits of this Shrike are, on the whole, those of the larger species, with this difference, that the Lesser Shrike, does not rob nests, but destroys insects, and therefore does good. It also, is a "Watchman." It sits on a high point and flings its glances round about. Suddenly it darts down, looks about, finds its prey, and flies back to its former perch. When it is keeping watch over a place where the ground is covered with thick growth, it hovers at about half the height of a man, sometimes until it can see something that will serve as prey. If it finds nothing, it will cease to hover, and flies back to its post. Near the highroad it will flit onward from tree to tree, generally slightly in advance of a vehicle, till at last, at some point or other, it turns away over the fields and with a peculiar undulating flight returns to the spot where it started.

The Lesser Shrike is a migrant, and departs for warmer places at the beginning of autumn, returning to its nesting place in this country in the spring. Its cry sounds like "Keejay." It is by nature quarrelsome, but it embellishes and enlivens the neighbourheed. In the warmer parts of Europe, it is the most common of all the Shrikes.

This species only wanders occasionally to England, a mere straggler, on migratory flight. If it be seen it must be protected, as a useful species, from "the man 
the gun" who shoots to sell or to enrich his own private collection.

The Lesser Shrike is smaller than the Great Shrike, but it is quite as beautiful and has the same deportment. Besides its smaller size, it is distinguished from its congener, by its black brow, the colour of which merges into that of the broad black stripe. The breast is a beautiful white, flushed with rose-colour. The white patch on the black wings is quite small. Otherwise the colouring is the same as that of the Great Shrike. Its nest is built in poplar trees bordering the highroadsometimes in other trees. It employs sweet-scented plants in building the nest. It lays five or six pale green eggs, which have a speckled ring round the thicker end. 


\section{I55}

\section{The Red-Backed Shrike. \\ (Lanius collurio.)}

This Shrike specially likes bushes at the side of a road, or the edge of a wood, and more particularly affects the whitethorn, or sloe bushes; but it sometimes ventures into gardens. It kills more than it can eat, so it impales the superfluous provender on thorns, so as to be ready when the bird feels hungry again, or when the weather is not favourable for hunting. So crickets, grasshoppers, cock-chafers, and, alas ! also young birds, are sometimes found sticking on thorns. As this bird keeps to its own district, it robs the nests of the small birds in a scandalous way, including that of the White-throat.

Care, therefore, should be taken to keep this ogre at a respectful distance from the gardens; he does less harm in the open fields, as he there employs his energies on the mice.

It is a migrant, and departs at the beginning of autumn, returning not earlier than near the end of April. Wherever it is, its "Geck, geck, geck," is frequently heard. Sometimes also “Treng, treng," reminding us of the Sparrow. It imitates the song of other birds in a remarkable way, even that of the Nightingale, often in this way misleading both man and birds.

The Red-backed Shrike comes to Great Britain in Máy. It is the commonest of our own three species; but is becoming rarer each year in Lancashire and Yorkshire, being more often met with in the wooded parts of the Southern counties and in Wales. A handsome fellow, with his grey head, mantle of chestnut- 
PARTLY USEFUL.

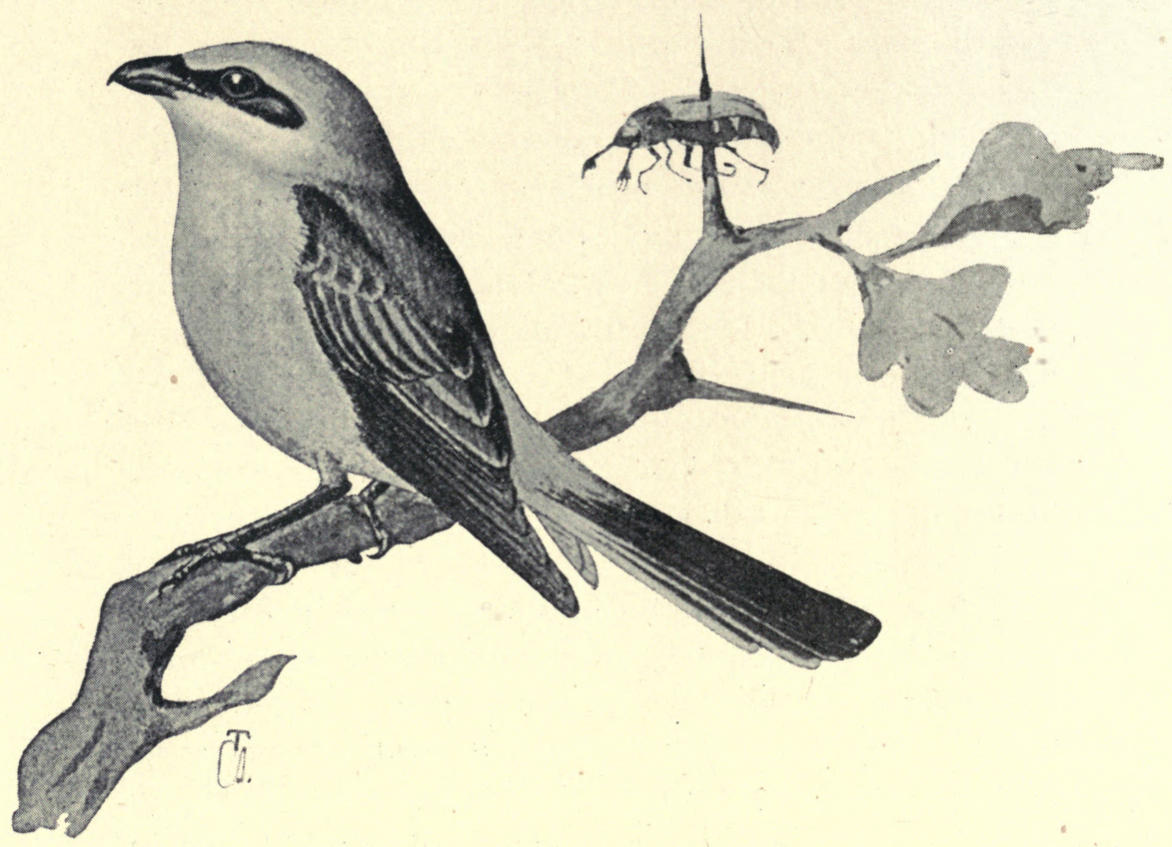

THE RED-BACKED SHRIKE. 
brown, and underparts a pale rosy buff colour, he has not the look of the cruel bird he really is; his song is fairly sweet, and I have heard of one which was so good a mimic that it could even bark like a dog. This particular one had been brought up in an aviary, I believe. All this species are, however, very imitative in their notes. In some parts of Germany, they are looked on as a great scourge of small birds, yet one or two of our English naturalists have tried to do justice to the pretty fellow. They have seen only beetles, wasps and other not-to-be-regretted small deer impaled on the thorns of his larder. In point of fact, small birds, especially our pleasant little Tits, disappear under his notice; Whitethroats also occasionally, as well as bigger fledglings.

The German naturalist Linz writes that he made some experiments in regard to Shrikes. In one garden he destroyed every Butcher-bird's nest that he could find, and shot the birds; and there he had plenty of fruit, because the small birds stayed and destroyed the grubs and insects. In another, a larger garden, he allowed just one Shrike to breed. Wasps and other creatures destroyed all the fruit near the part where this Shrike's nest was. In a third garden Lenz allowed Shrikes to nest freely, with the result that all the insect-eating birds forsook the place, or else were destroyed by the Butcherbirds, and there was no fruit. Writing of the Redbacked Shrike, one of our leading authorities in bird matters notes that in its larder he has seen the bodies of large moths, dragon-flies, mice, and sometimes a small bird from which the head has been wrenched, and many a cockchafer ; and Canon Tristam considers that the food of the various species of Shrikes is almost entirely 
cockchafers, where they are to be had. The Rev. T. Wood again ranks them with the Owls for usefulness. A French naturalist also says they have every right to be placed on the list of useful insectivorous birds. It would seem to depend much on the nature of the district whether this bird is to be welcomed or otherwise.

The Red-backed Shrike is 7 inches long. Its whole shape and colouring-still more its habits-are those of a true Shrike. Crown and neck a beautiful grey; mantle reddish-brown; the folded wings show no white patch. Underparts pale rose colour, throat white; across the eyes and towards the ears, is the broad black band. The middle feathers of the tail reddish-brown, the outside feathers white near the root. The breast of the female bird is pale, crossed by brown wavy lines. The upper mandible is serrated and has a slight hook. The nest is usually placed in bushes; it contains five to seven eggs nearly white, with a ring of small darker speckles, sometimes at the larger and sometimes at the smaller end. 


\section{The Lesser Whitethroat.}

(Sylvia curruca.)

This simple, modest, agreeable bird is valued and loved by us, because it comes in such a friendly way near our houses and ourselves. It nests in orchards, and more especially in gardens where there are bushes, and charms us in the early spring with its sweet trilling song, "Lee-lee-lee-lee-lee." The little song is quite simple, being just the repetition from six to eight times of the syllable "Leeleelee." Its call-note is "tack-tack-tack." It keeps the feathers of its head erected whilst singing. Its food consists of all kinds of harmful insects for which it hunts without rest, and is therefore no less useful than the Titmouse. It feeds also on various berries, but without doing any harm. The hen shows great selfsacrifice in rearing her brood, amongst which is often found a stranger-the Cuckoo.

Its nest should be protected from the house Cat. Whoever protects it secures its services for himself. The Whitethroat is migratory, and so exposed to many dangers.

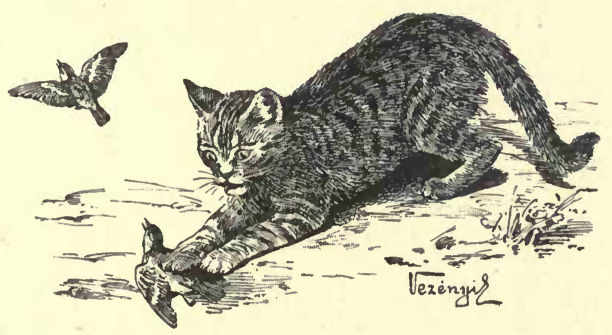

Mr. Herman gives us only the Lesser Whitethroat. With us what we call the Whitethroat proper is much 
USEFUL.

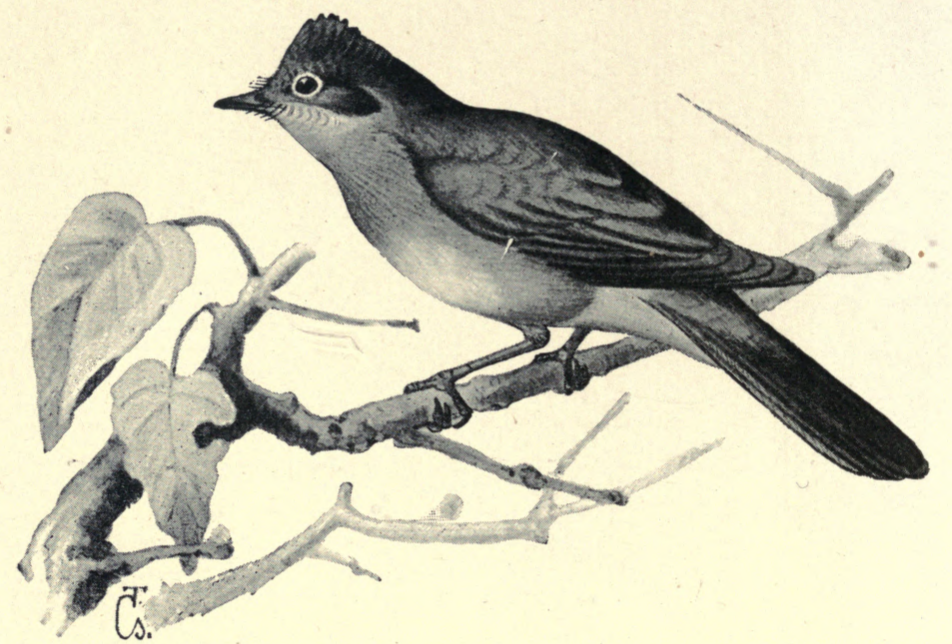

THE LESSER WHITETHROAT. 
more common (Sylvia cinérea). Both species arrive in Great Britain at the same time, that is about the second week in April, to stay until the beginning of September. With us they nest in brambles and low hedgerows, and because of the fondness of nettle beds, schoolboys know it mostly as the "Nettle-creeper." The male is a courageous little bird; he will often follow one along the side of his favourite hedgerow, flitting from branch to branch with the feathers on head and throat bluffed out and agitating his tail. We hear his song by night as well as by day.

The Lesser Whitethroat is $5^{\cdot} \mathbf{2 5}$ inches long. The crown is ashen-grey; cheeks darker, mantle grey-brown; back and breast white, merging into yellowish-red at the sides. The side feathers of the tail are wedge-shaped, the feathers near it having small indistinct spots. Beak small, awlshaped; legs strong and bluish. The nest is generally found in whitethorn hedges and sloe-bushes, at about two and a half feet from the ground; in gardens the nest is placed higher. It is composed of fine grass and root fibre, interwoven and compacted with spider's web, and lined with pig's bristles and horse-hair. The bird lays five or six beautifully formed eggs, which are white or bluish with delicate speckles, which are thicker at the larger end of the egg, round which they form a ring. 
USEFUI..

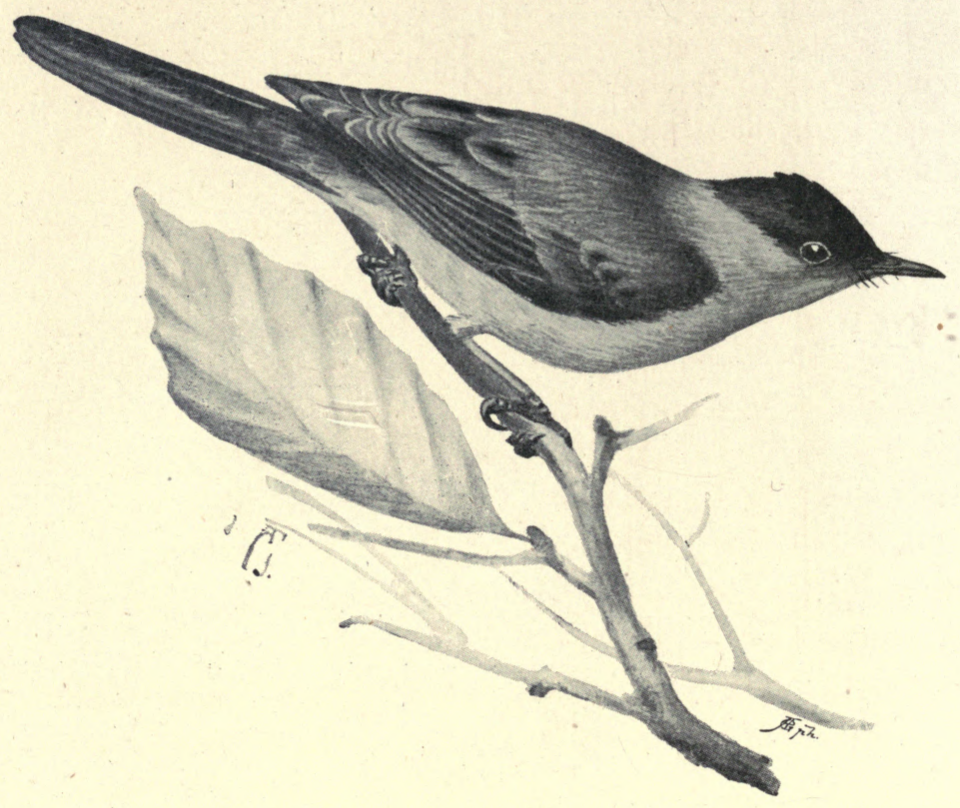

THE BLACKCAP. 
The BlackCap.

(Sylvia atricapilla.)

The Blackcap prefers the underwood, particularly where higher trees stand solitary; it also nests in gardens, even in the public gardens of large towns, where it feeds on all kinds of insects, and so it serves wood and garden equally well. It leads a happy family life, and during its courting days the little wooer is full of joyous song. The song is simple, and does not approach that of the Nightingale in our opinion, although others say it does; it certainly cannot express so many phases of feeling, but it is as lovely and joyous as that of a merry child. It is heard first from one side of the bush, and then from the other, and it carries delight into the heart of the listener. Hoffman represents the song of the Blackcap by the syllables "Rutia, ruetidi-rutia, tuedili, tuedia." Its mating call is "Take, take, take," the warning cry " Rarr." Towards autumn this bird eats all kinds of berries from the bushes-elderberries, blackberries, and others; in the garden it picks currants, without, however, doing any serious mischief, or being able to do so, for its principal food is composed of insects.

The bird-catchers ensnare it on account of its charming song. They cover its cage with greenery, so that it may imagine itself in the underwood, and thus the poor thing lives and learns the songs of other captive birds.

The Blackcap loves our old English hedgerows, about which it can find all its necessary insect food and also good cover. It is not a very commonly distributed bird 
with us; like the Nightingale, it is local in its habitat. The young fuss about after their parents for food supplies, after they have left the nest, more than most young birds do. Often the Blackcap builds in a privet hedge, or some bush near to garden or orchard, for the sake of the fruit of which it certainly avails itself a little. Do not grudge it, the song will make up for a slight loss of fruit, which is the more plentiful for the little bird's making away with insect pests that infest the same precincts.

The Blackcap's mantle is olive-grey, underparts nearly white; the colouring of the head forms a black cap, which extends over the eyes: hence its distinguished name. The cap is brown on the female bird and its young. Tail and wings dark-brown; beak thin, awl-shaped : legs strong : very bright dark-brown eyes. The nest is always found in thick bushes, near the ground, and it is furnished with grass and rootlets, and also the webs of insects, sometimes hair, but very little feather. It contains five or six eggs, which vary in colour, being sometimes brownish, sometimes nearly white or olive-grey, speckled or otherwise marked with a reddish tint. 
The Nightingale.

(Daulias luscinia.)

The Nightingale leads a quiet domestic life among the thickets. It has much occupation on the ground, whence it derives its livelihood, its food consisting entirely of grubs and insects. In the pairing season, and at the time when the hen is sitting, the male bird perches on a twig near the nest and sings his song-now mournful, now stirring, now tender; the finest song produced from any bird's throat! Enthusiastic bird-fanciers have put words to the Nightingale's song and turned it into verse. It begins thus :-

Fid, fid, fid! kr-kr-zi-zi, doredo, reredezit.

We have a native congener, the Meadow Nightingale, which is larger than the bird described above, and has a darker and fuller breast. The Hungarian Nightingale of the bird dealers begins its song thus:-

Philipp-Philipp-Philipp,

Tarak-Tarak-Tarak,

Diderot-Diderot-Diderot.

Bird-catchers have been very destructive to this noble, useful bird on the Continent.

The Nightingale comes to Great Britain in the middle of April.' In August the young birds take their departure, but the old birds stay until September in order to finish moulting before taking flight. It has been supposed that the migration is made singly, not in flocks like that of other small birds; but a naturalist has recorded having once seen great numbers of Nightingales resting 
USEFUL.

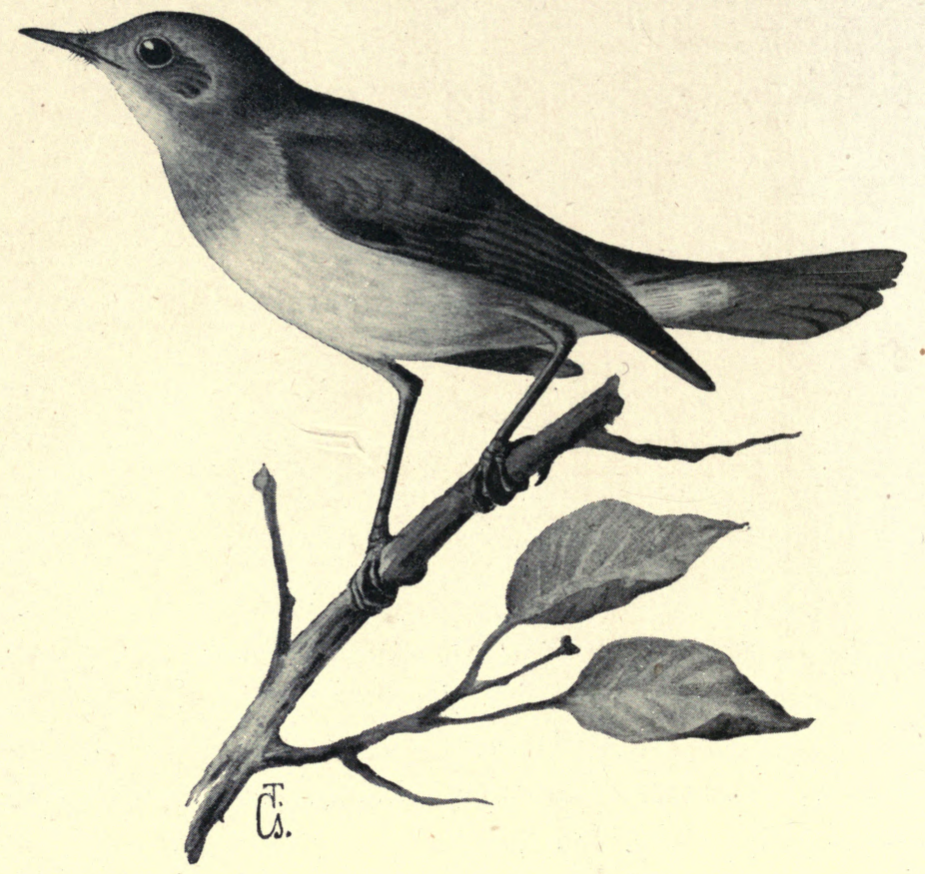

THE NIGHTINGALE. 
under the bathing machines along the whole length of the shore at Brighton.

This fine singer is very local in its appearance. In the West of England it is rarer than elsewhere, and beyond Devonshire it is said to be quite unknown. In the Midlands it is scarce, and in the Northern counties it is entirely absent excepting in Yorkshire, where it is getting more common. They seem to be capricious in their comings and goings from given localities; no doubt their presence depends on the season's scarcity or abundance of the food they prefer. The nestlings live on spiders, ants and small green caterpillars in June, and they afterwards frequent fields planted with peas and beans. The adult birds feed on worms, insects and wild fruits, especially the berries of the elder.

The Nightingale is as plain in plumage as it is marvellous in song. The mantle is russet-brown, shading off into reddish-chestnut near the tail, which is rust-colour, underparts whitish. It is scarcely as large as a Sparrow, and is much more delicately formed. Beak thin and pointed, legs slender. The shining, dark-brown eye has a brilliant glow. Its nest is placed among the bushes of a thicket, always near the ground. The outer covering is of dry leaves, then come blades of grass and fine rootlets, sometimes having hair interwoven with them. It does not stand out from the surrounding objects, and requires a sharp eye to discover it. The clutch consists of five or six olive-green eggs, with darker reddish-brown veining and speckles. 


\section{USEFUL.}

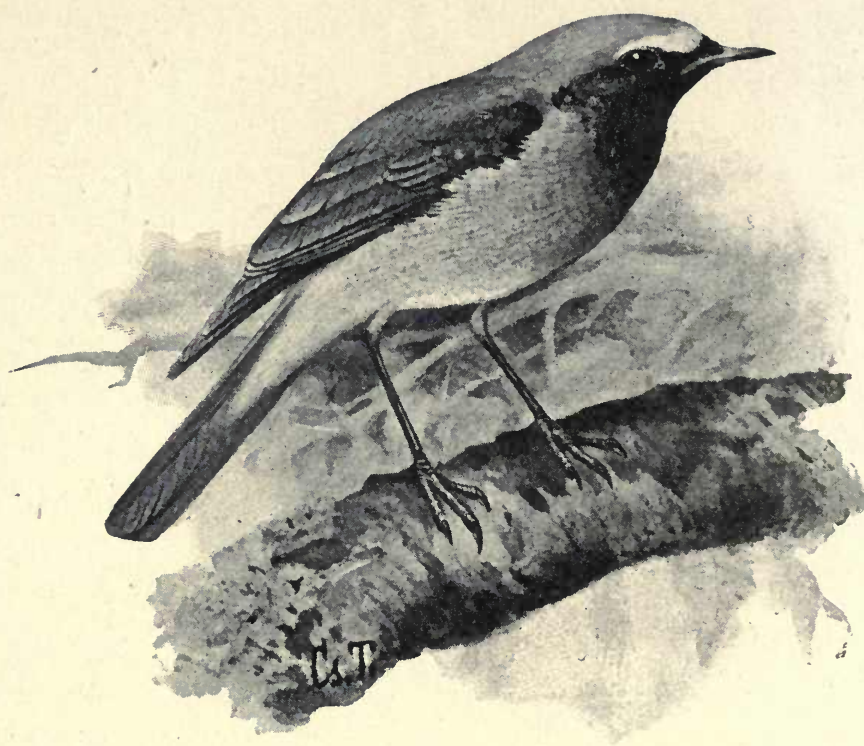

THE REDSTART. 


\section{The Redstart.}

\section{(Ruticilla phoenicurrus.)}

This pretty and very useful bird quickly attracts notice in our gardens by its lively disposition. When it flies the tail spreads out, and then, when the bird settles again on any post or ledge the tail moves in a quick, tremulous way that is most amusing.

It usually perceives the creeping and flying beetles on the grass borders from a higher point above them; the former it picks up, the latter it swallows on the wing, twisting and turning about as circumstances require. It lives on all kinds of grubs and insects, and hence its great use in wood and garden. In autumn it takes the berries from the bushes, but without doing any mischief. Its mating call sounds like " Fid-fid-fid-tik-tik-tik," and also "Weet, weet, tak-tak, and ends with a smacking sound. In some places in Hungary the bee-keepers are great enemies of this charming little bird, believing that it steals their honey. This is not true, however, for it only catches the drones, which have no sting, takes the rejected, spoiled larvæ, and the destructive wax-mite. From its usefulness it is worthy of all protection, and it a joy for heart and mind.

To us also in Great Britain where this species is generally distributed it is a joy, and in orchards its presence is most welcome. The red about the tail shows brightly as the bird darts from branch to branch. I have watched it myself where a nesting box has been put up for its use in an apple tree, until the little pair became quite used to my presence and to watch their pretty, affectionate ways was delightful. In speaking of 
nesting boxes, one must give a warning in connection with those smaller birds who like to nest in holes in walls and trees. I have seen them with lids at the top for the proprietor to open, which, through stress of weather and weak rusty hinges, soon came to grief. I regret to say this happened in the case of the pair I knew best. The lid was defective, and one night or morning early soon after the nestlings were hatched out, a Shrike or a Crow routed them out, to my great sorrow.

- The Redstart is an elegant gay-coloured bird of slender shape, in other respects like the Robin. Throat, lores, brow and bill-base are a fine black. The upper part of the brow is pure white, passing into the bluish-grey of the crown. Back of the head and mantle also of the same beautiful bluish-grey; breast, rump, and tail a brilliant chestnut-red, but the middle feathers of the tail grey. Beak and legs delicate, but strong. The female bird and the young are less brightly coloured. The nest is found in cracks, holes, convenient corners, such as are under the roof of summer houses. It is rather carelessly put together, but well-formed, and is lined with hair and feathers. The bird lays five or six eggs, of a fine rare blue-green colour.

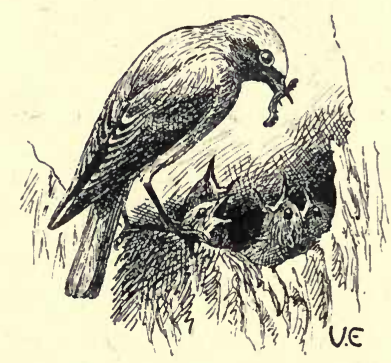




\section{The Black Redstart.}

\section{(Ruticilla titys.)}

THE Black Redstart which was formerly rare with us, is: now a well-known visitor to many parts of our coasts in the autumn and winter, especially to Cornwall and Devon. It does not as yet breed with us, however. It visits Ireland also, particularly on the east and south coasts. It is called the House Redstart, and its congener the Garden Redstart on the Continent; the one under notice frequents the roofs of buildings, and it places its nest in châlets, holes in walls, sheds, etc. It is a useful little bird.

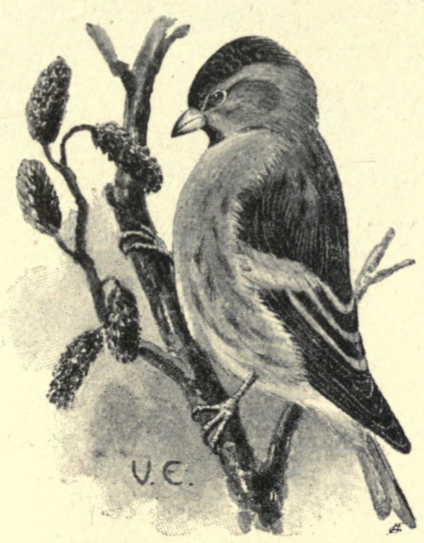

The pretty Siskin. 


\section{USEFUL.}

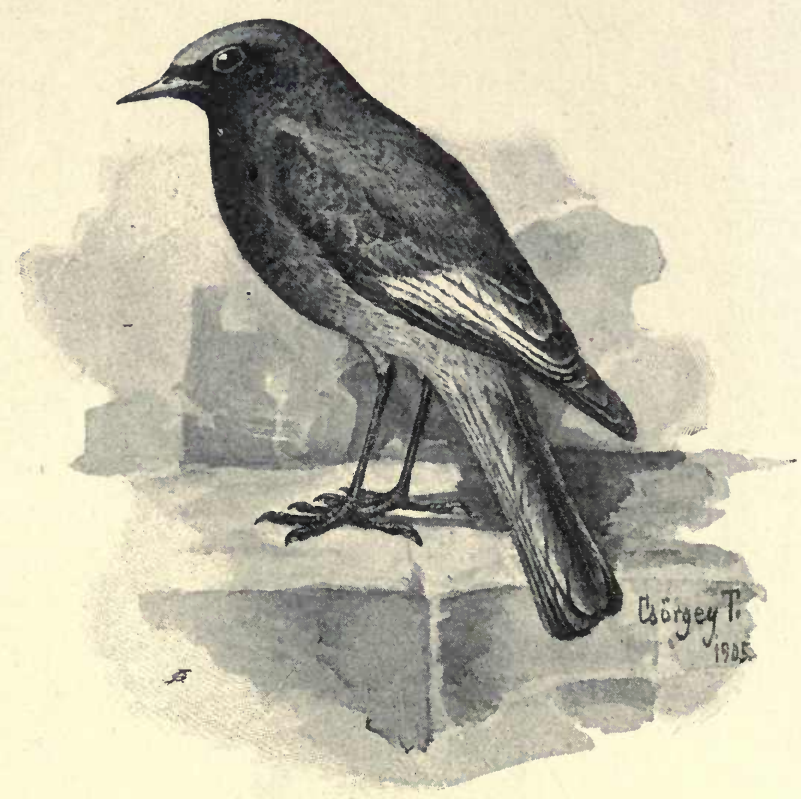

THE BLACK REDSTART. 
The Tree Pipit.

(Anthus triviális.)

Frequenting the woods, the Tree Pipit seeks only the clearings, especially the wild parts, where these and copsewood alternate, and the ground is mossy. At the time of migratory flight it likes to rest on vegetable fields and cornfields. It will rest willingly on trees, but prefers. the ground. Very small seeds it will eat, but all kinds of grubs and caterpillars and insects it prefers. The

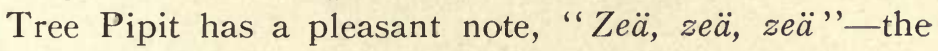
mating call is more like "Seele, seele, seele." It is absolutely useful in its mode of living.

It nests in Hungary more numerously than any other of the Pipits, for it has relatives which only visit our neighbourhood. At the time of migration, they arrive, rest themselves, and go off again.

In addition to the Pipit here described there is the Water Pipit, which breeds here. It seeks the mountain districts in summer, but takes refuge in the valley in winter; Richard's Pipit, rather larger than these others, and with longer legs and a very long hind claw. The Meadow Pipit only passes through our land, like the Tawny Pipit; both of the latter nest in the far North, and they go far South in the winter.

The Tree Pipit comes to the South of Great Britain early in April, and it is spread pretty considerably throughout the country, excepting in Cornwall and Wales. As yet it is not, I believe, in Ireland. The song of this bird is rather like that of a Canary. It begins on the highest branch of a tree generally, after 
USEFUL.

8

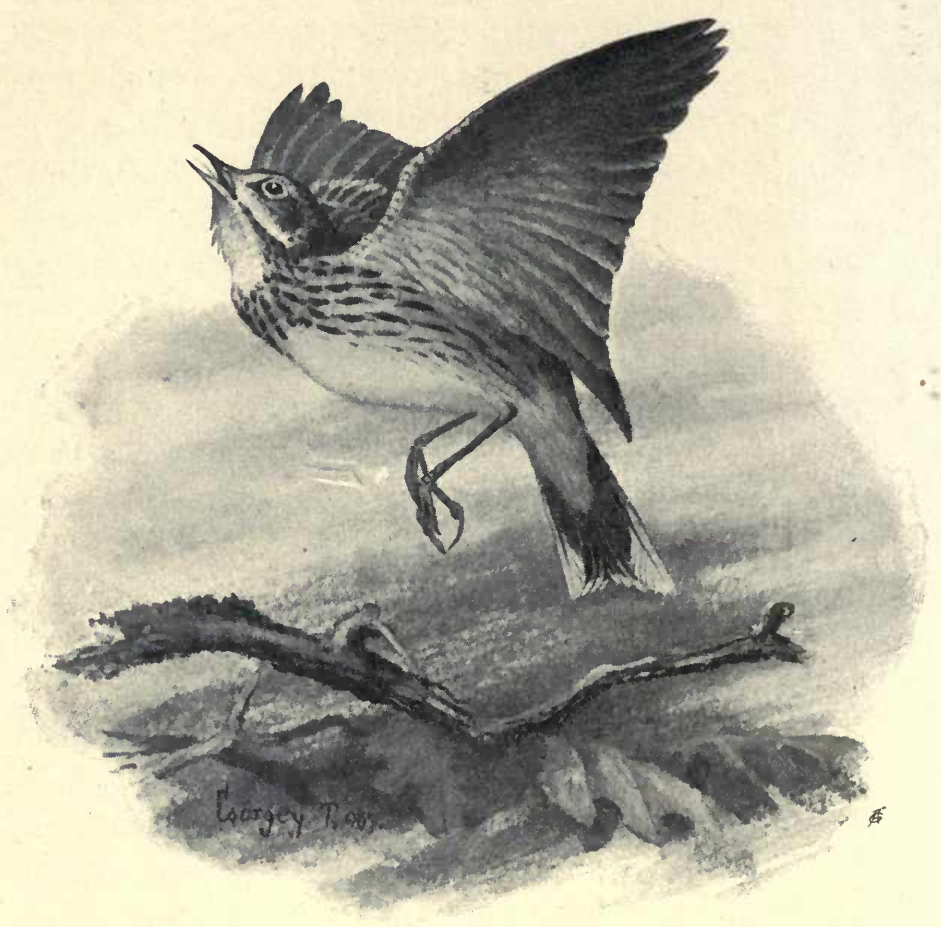

TREE PIPIT. 
which the bird hovers a little, then descends, singing still, to the perch he started from.

The Meadow Pipit is the best known member of his family with us. Ground-lark, Titlark, Ling-bird, Mosscheeper are some of its local names. It seems able to make itself at home anywhere in summer, but in winter it seeks the fields in sheltered places, near the coast by preference. Its food consists of insects, worms, molluscs and small snails, with seeds in winter. The little bird works its creeping way up the grass or heather, taking now and again quick little runs. The flight is wavering and jerky. The Titlark has a very strong smell about it, dogs " point" it frequently.

In size the Tree Pipit most resembles the Wagtail, but it has a shorter tail. Its general colour is more like the Lark, but it is less speckled. The mantle is olive-green, the breast yellowish. The points of the folded tail are formed by the three first flight feathers; the fourth is much shorter. The nail of the back toe is long like a spur, but not so long as the toe. The beak is delicate and slightly awl-shaped. It is a nice modest little bird; its flight dips and rises again continually. It builds its nest cleverly with soft materials in the shape of a saucer, and places it on the ground on a clod of earth, under the shelter of a heap of stones, or on a grass ridge. Five eggs are laid which are very varied, a dull blue, sometimes brownish, sometimes white, with dark spots. 
USEFUL.

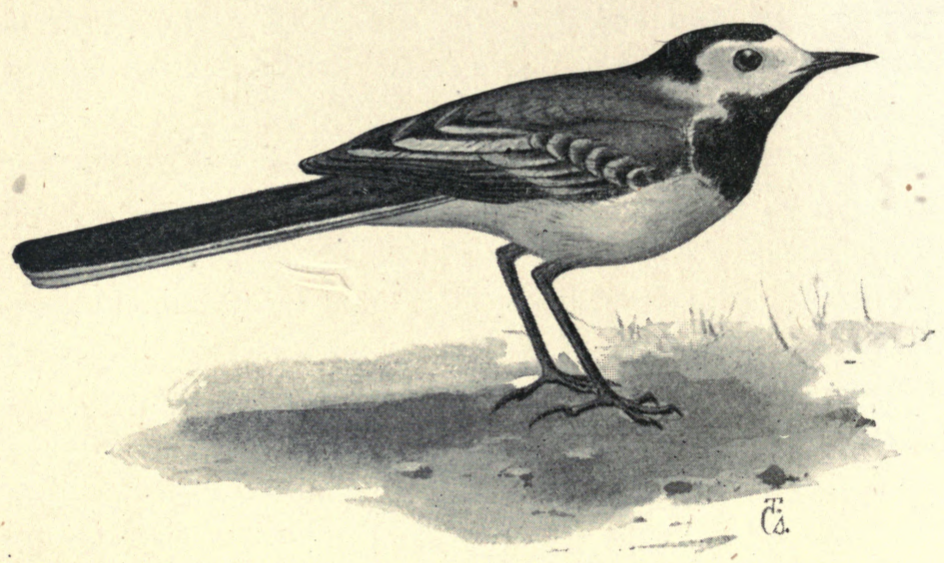

WHITE WAGTAIL. 


\section{The White Wagtail.}

\section{(Motacilla alba.)}

W $\Lambda$ GTAILS are all migrants and arrive in Hungary in great numbers.

This is a lively, elegant little bird, that walks and runs well, is very active, and always wagging its tail as it goes. It hops daintily from stone to stone in the shallow water, picking up insects busily, and snapping at the flies and gnats; and over the tall grasses and banks of the water, it dashes into the air, turning and twisting in the pursuit of insects. When there is pasture land near the water, it shows itself to be a good friend to the cattle, by destroying the flies and gnats and the tiny midges of the dragonfly kind, which would otherwise torment them. Its congeners in Hungary are the Yellow Wagtail, whose underpart is bright yellow, and mantle olivegreen, which wags its tail less, and confines itself to cattle pastures; the Mountain Wagtail, the upper part of which is ashen-grey, and the under side brimstone yellow. Its call is a clear "Zeewit-zuyit-beuees, or zeueess," sometimes it sounds like "Kwee-kwee, kweereeree-kweeree,"

The Wagtail is 7.5 inches in length, and has a long tail. It is a very charming bird. Its plumage is of three colours-black, white, and ashengrey. Crown, neck, and throat black; brow, cheeks, and underparts white; mantle grey; tail and wings black, the feathers of the latter being edged with white; the two outer feathers on both sides of the tail are mostly white. Rump dark-grey, underneath the tail white; bill 
awl-shaped, and black, as are also the slender legs. It builds its nest on the edge of the water in all sorts of places : in holes, between stones, in cracks in the earth, among roots or in wood-stacks. It lays sometimes as many as eight, but usually five white eggs, finely speckled with dark colour, the speckling thicker at the larger end, in a ring round the egg.

\section{The Blue-headed Wagtail.}

\section{(Motacilla flava.)}

THIs very handsome little bird, which is smaller than the White Wagtail, and does not wag its tail so much, inhabits the low Hungarian plain, and the pastureland generally of the open country, especially moist moorlands, and the banks of marshes, where it keeps close to the grazing animals, which are mostly swine and buffaloes. When swine trample down the bank of the ponds the bird approaches, and picks up the water insects and larvæ which have been exposed in the disturbed ground, or if the buffaloes trample the earth on the edge of the marsh the Wagtail is sure to be close on their heels to secure its share of food. It builds its nest in the grasses of the meadow or at the roots of the bushes in the hedge. It usually lays five eggs, which have light flecks on a dingy white ground.

A bird I always looked for eagerly in the days of my youth, on our Staffordshire moorlands was the Yellow 
Wagtail with its lovely tints. It would come tripping blithely along a certain road on its way from one rough fallow field to another, a most dainty, and I fancied then, even foreign-looking little creature. It has a prettier song than its relatives, the Grey and the Pied Wagtails, and is altogether a daintier looking bird. Nor is it so common, being very local in its distribution. Leaving us in September, little parties of the Yellow Wagtails are formed then, and some districts only make their acquaintance with these birds when on their migratory flight. Lately I heard of a company of about seventy Wagtails resting for the night in Kew Gardens grounds, where they had not been noted before. They frequent the meadows beside the Brent by Perivale, Ealing, where small, thin-shelled molluscs by the stream, and insects stirred into activity by the heavy feet of the grazing cattle, furnish them with food. I watched one day a pretty sight,- - nir ile Wagtail in close attendance on an old sheep. The way it darted nimbly about this animal's face, picking off the tiny flies as the creature fed was wonderful. Sometimes you may chance to see one picking the torturing little insects out of an old horse's ears as it lies resting on the sward.

The yellow species is called Motacilla raii, but the Abbé Vincelot, who wrote half a century ago, on the birds of Maine-et-Loire, treating speciallv of their names as descriptive of their manners, call it Motacilla boarula, and he said he thought the latter designation came from Boaria, an old name for Bavaria, used after the Boïens, driven by the Marcomans from Bohemia, settled there. This name Boïens seems to have been given to the tribes who reared and tended cattle. There were Boïens of Gaul, of Italy, and of Germany. In Poitou an ox is still called 
boe and the grazier boier. By the ancient Romans the beef market was called the forum boarium. And so the name of boarule given to the Yellow Wagtail may be supposed to indicate this habit of following up the cattle in quest of his insect food. Bergeronette, the common French name of this charming and useful species, is equally descriptive of the bird as an ally of the shepherd.

The Pied Wagtail, Motacilla lugubris, is our common and well distributed species. The Grey Wagtail, $M$. Melanópe, a beautiful bird with its longer tail and yellow tints, frequents our hilly districts and mountain streams; but, the Blue-headed species is only an irregular visitor to our Islands, on migration. The food and habits of this family are alike, and they are all most useful to the grazier and farmers generally.

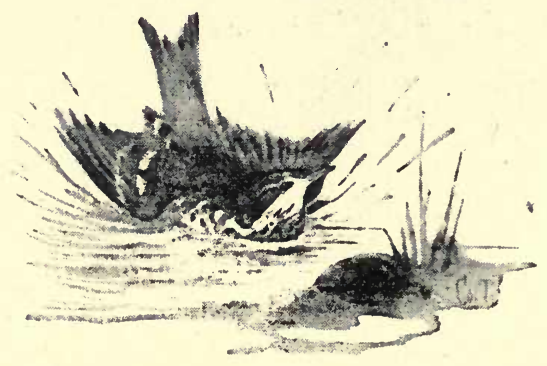

A Morning Bath 


\section{The Great Reed Warbler.}

(Acrocephalus turdoides.)

This Reed Warbler lives exclusively in reed beds, and, as it is fairly common, inhabits a large number of such places, so that in the pairing season the whole neighbourhood resounds with its love song, which even overpowers the croaking of the frogs. There are usually large numbers of the birds near together, and all join with one voice in the concert. It goes on from morning till night. Indeed during the most eager time of its wooing it goes on all night.

The song is sometimes expressed thus :-

$$
\begin{aligned}
& \text { Karrey-karrey-karrey } \\
& \text { Ker-ker-ker } \\
& \text { Hedder-hedder } \\
& \text { Duee-duee-duee, etc. }
\end{aligned}
$$

Where the reeds are thickest it shoots between them, as a weaver's shuttle shoots between the threads. What is still more clever is the way in which it climbs about the straight tall stalks of the reeds. It clasps the reed with its toes and claws, and immediately it seems to be up on the top, then in a moment it slides down again and vanishes among the reeds. And of what use is all this? This bird is of use in its own way, in places inaccessible to others. It destroys innumerable grubs and insects, which frequent water and boggy land, and does its best to make such places habitable. The food of this Reed Warbler consists principally of insects and their larvæ, although in the autumn, like most creatures, instinct teaches it to eat some fruit for health's sake, in the shape of berries, particularly those of the elder.

The nest of this Reed Warbler is one of the marvels 


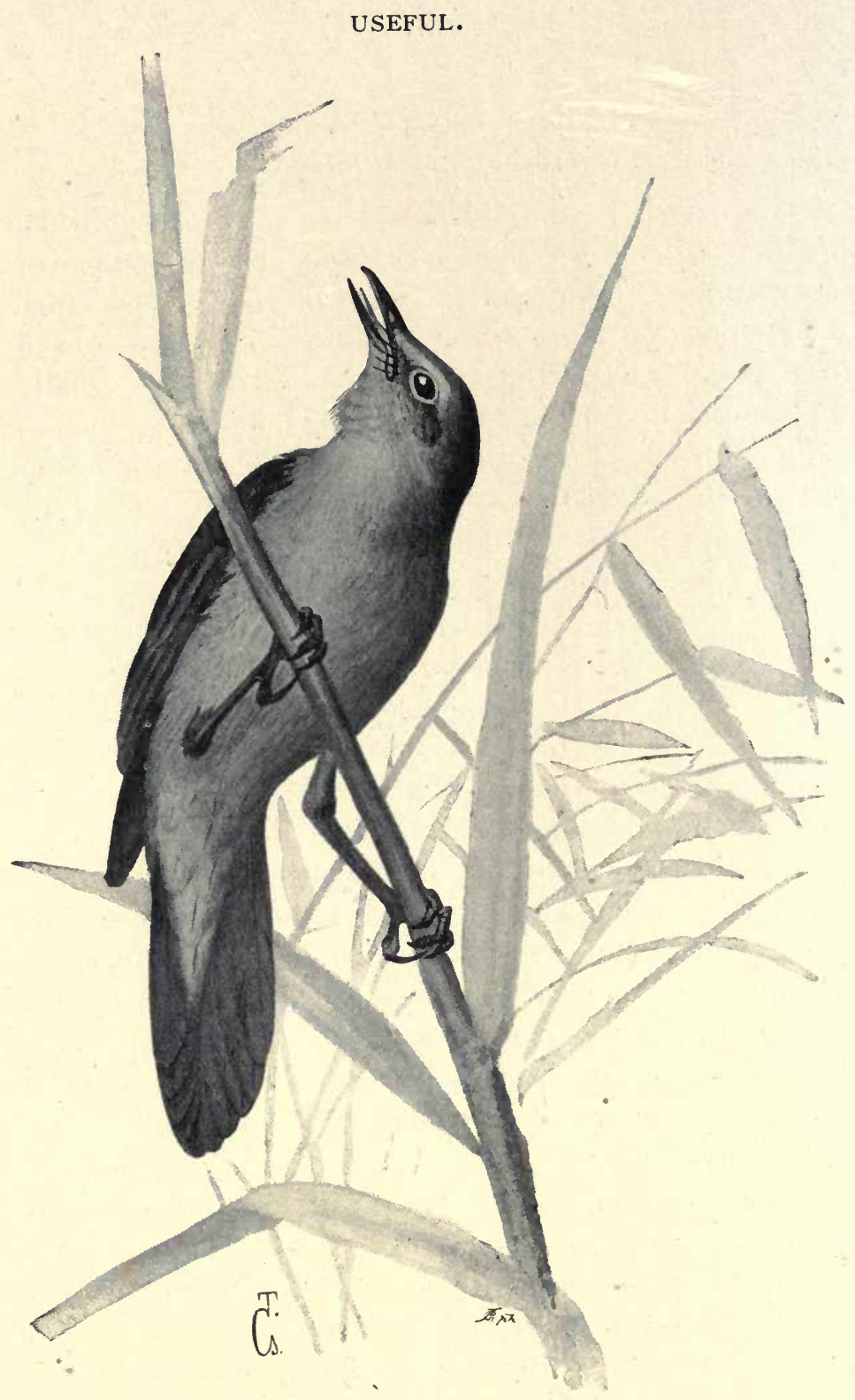

THE GREAT REED WARBLER. 


\section{NEST OF THE REED WARBLER I83}

of bird architecture. It is a real work of art, because, in its perfect suitability for its purpose, it shows an amount of calculation that few men would think a bird capable of.

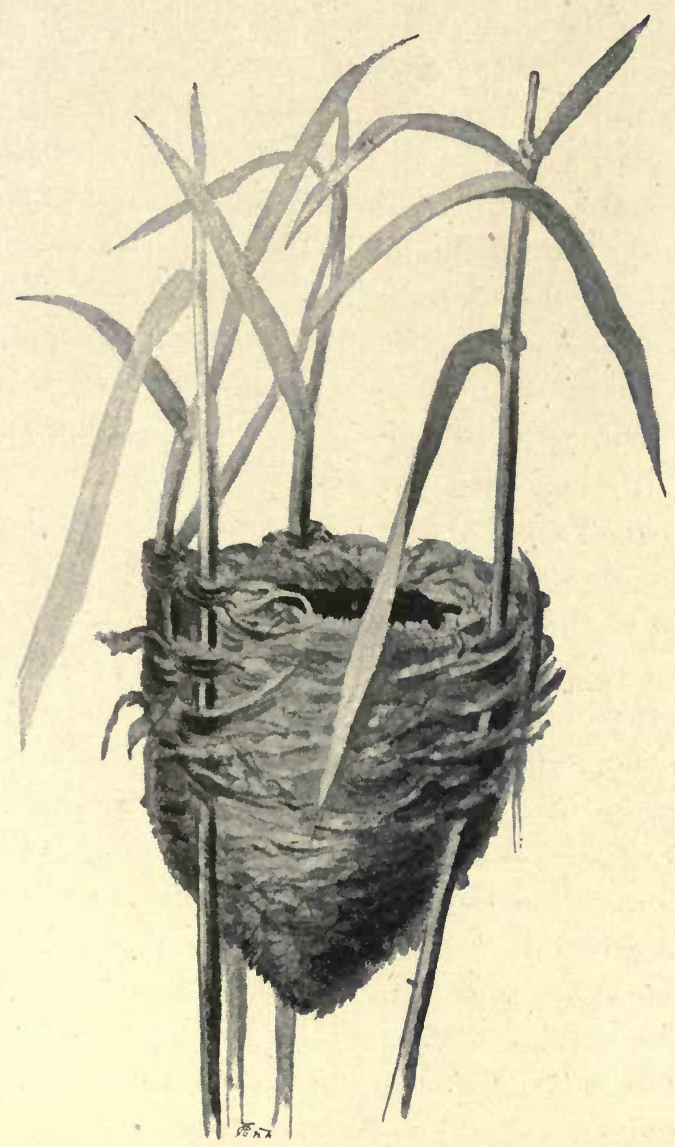

Whoever is acquainted with the nature of marshland, and the reed beds that border it, knows that on the smooth surface of the water, the breeze, the wind, the storm have free course, and can at times bluster and 


\section{I84 NEST OF THE REED WARBLER}

rage. Everyone also knows that the lightest breezes moves the leaves of the reeds, bends their stems and sets the whole wilderness of them in motion, like the water itself. The wisdom of Nature has placed this bird of the reed beds here, and so formed it that it could live nowhere else. Therefore it must build its nest in this unstable-looking spot and can do so in perfect safety; so that it can lay its eggs, hatch them, tend the young birds which are at first blind, feed them and bring them up until they are fledged and like their parents.

It is no small undertaking to build among the bending stems a nest which will afford security in calm weather and also in storm! If the bird fastened it to one stem, and the wind were to come, the fastenings would soon be torn away, and all destroyed.

What then does the bird do? It chooses three or four stems at about equal distances standing near to each other. On these it darns and knits its nest in the shape of a high, eastern, fur hat reversed : attaching it also with tough grass to the reed in such a manner that it can give way on the stalk when it waves in the wind, so that the stalk cannot tear the nest. The cup of the nest is deep, narrowing a little at the upper edge to prevent anything falling out when moved by the wind. In this nest the Reed Warbler lays five or six eggs of pale green with darker speckles, which are hatched in fourteen days. It is a perfect work of art.

The Great Reed Warbler is 8 inches in length, that is, an inch less than a Thrush; and its form is not unlike that of the Thrush. The upper side is brown, shading into rust colour; over the eye is a lighter stripe, and round the ears the plumage is also a lighter colour. The underparts are whitish, tinged on the sides with yellowish 
clay colour. Beak like that of the Thrush, rather strong, slightly curved, pointed. Legs strong, suited for clinging. The nest is treated of separately.

We have a smaller relative of this bird in England, although ic is not known in Scotland, and is only said to have been taken once in Ireland. Our Reed Warbler (Acrocephalus streperus) arrives regularly in the latter end of April, to stay until September. It is common in those places that suit its way of living, in the Midlands and the Southern and Eastern counties. In form it resembles its larger relative. This species does not confine itself to reeds or to watery quarters; it has even been known to build in a garden at Hampstead. The slender branches of willows or alder beside a running stream suit it well. Still it prefers reeds, and its nest also is supported by being woven about and through three or four, or even two reeds. The building is begun whilst the reeds are short, but by the time the young are hatched the nest is three feet above the water. That wandering creature the Cuckoo will even drop her egg into this hanging nest; indeed she is fond of it. The song of this species is at its loudest and pleasant during the long summer twilight. It is a useful little bird.

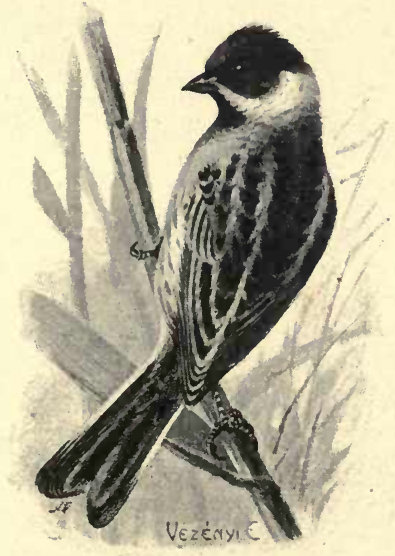

The Reed Bunting. 
USEFUL.

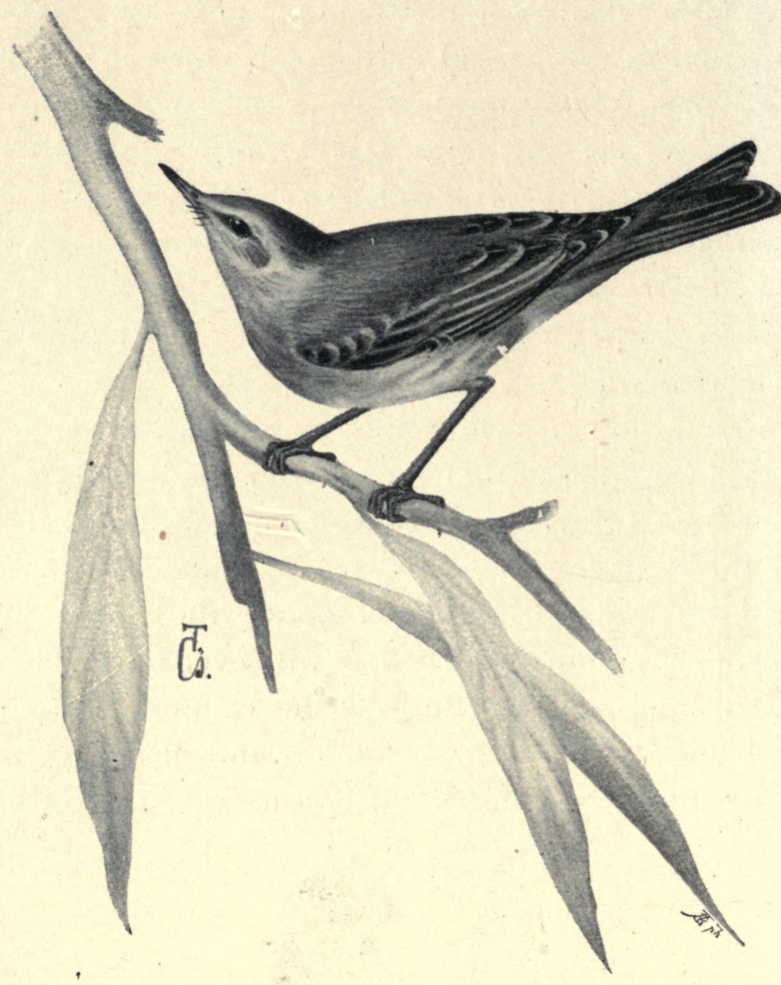

THE WILLOW WREN. 


\section{I87 \\ The Willow Wren. (Phylloscopus tróchilus.)}

THIs bird is called the Willow Wren because it loves the willow trees, the leaves of which, both in form and colour, are adapted to hide and protect it.

Its nest is well hidden, being often placed near the ground, under overhanging grasses and bushes, and built of materials found immediately around the chosen site; it can only be discovered by the eyes of an experienced bird-nester. It is covered over. The clutch consists of five or six little white eggs, speckled with reddish-brown.

It is a lively, active bird, that likes to frequent the tops of trees in thick woods, where it hops briskly from twig to twig, and is never still. But neither its colour nor its movements betray its presence and nature as does its voice, which is really extraordinarily strong and farreaching, considering how tiny is the singer, and still more tiny its vocal organ. Its song is heard in spring, and sounds like Zilp-Zalp, Zilp-Zalp, and so on. Its. busy call-note is Whit, whit! It feeds on the insects. which it finds on the trees. In autumn, when starving, it eats elder-berries and such things, but does no harm whatever. As a loud harbinger of spring, and a bringer of glad-tidings we welcome and protect it.

About the first week in April the Willow Wren comes. to us in England, where it is the commonest of the three small greenish-yellow Warblers that come to usthe Chiff-chaff and the Wood Wren are its congeners. Owing to the shape of its domed nest it has been given 
the name of Oven-bird; indeed all three are known by that name, and the Willow Wren also by that of Haybird, because of the dry materials it uses for its nest. This species is very useful to the gardener, as its food consists almost entirely of insects, flies and aphides.

The Willow Wren is a little longer than the Chiff-chaff and an inch longer than the Wren. The upper parts, except the crown, is greenish-brown, passing into a yellow tinge; the underparts white, breast and throat pale yellow; the cheeks golden-brown, the inside of the wings yellow, legs brownish; the under side of the toes yellow. All is subdued, nothing glaring on this delicately coloured bird; indeed, all is delicate, including the bill, which is pointed and adapted for investigating the tiniest cracks and bud axels. 


\section{I89}

The Spotted Flycatcher.

(Múscicapa grisola.)

THE habits of the Spotted Flycatcher are quite different from those of its feathered companions in garden and forest, such as the Tits; for while the latter are always moving, darting here, hunting there, the Flycatcher sits quietly on the extreme end of a bough, on some point, or on a post, and watches for flying insects exclusively; flies, beetles; or near the bee-house it lies in wait for drones, but it never snaps at a stinging bee or wasp. It is quiet, only occasionally moving first one wing and then the other, as if to ascertain that they are in working order; then, as soon as it sees a flying insect, it darts forward, sure of aim as the Swallow, seizes its prey, and flies back in a fine curve to its post of observation.

The Flycatcher then, belongs to the useful birds, especially in gardens, where it destroys the harmful insects which fly among the trees. If it should happen to make away with the gall-insect, among others in the woods, that will not outweigh its good deeds. In gardens, at all events, it ought to be cherished and protected. Place a nest-box, such as it loves, with a wide opening, and let it nest there. 'There is not much to be said for its song; its call note is "Tschee, tschee."

The Spotted Flycatcher is one of our latest British spring migrants, its usual time for coming is about the first week in May. Although it feeds almost exclusively on insects, it has been known to eat the berries of the mountain ash; I have noticed indeed that these disappear 
USEFUL.

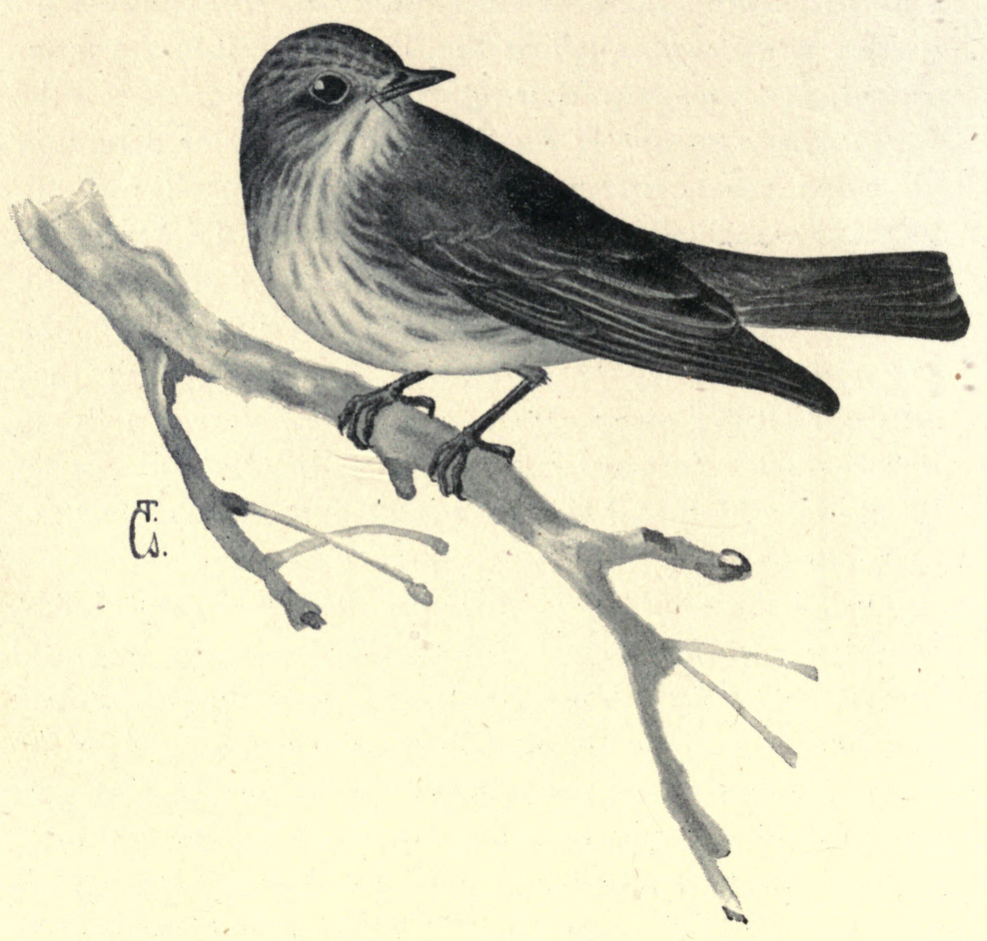

THE SPOTTED FLYCATCHER. 
before the birds more quickly than other wild berries. It is local with us in its breeding habits. It is one of the few species which still breed in some of our London parks and the larger gardens in town. The nest may be found among old creepers, but in the country it is.often built on the beam of an outbuilding, and so it has been called the Beam-bird. It is a charming little creature to note as it sweeps round in quest of insect life. I was once watching a nest in a creeper on the porch of an old farmhouse. The young birds, tightly packed within, gasped greedily for the food brought by their parents. One had a fly too big for its swallow; it was stuck in its throat, and the fledgling graciously allowed me to push it down with a pin.

It is a charming sight to see the parent bird catch its prey when on the wing, and carrying it promptly to the nest within the creeper. "Not only tiny insects and moths go there, but also the bodies, denuded of their wings, of many a white cabbage butterfly, which would otherwise have deposited her small white eggs on the leaves of the cauliflowers in the kitchen garden close at hand. These eggs would become green grubs, which would injure the plants and make them unfit for food. The quick eyes of the bird and his clever flight put an end to the mischief so far as many a cauliflower is concerned. Flies, beetles, and aphides in hosts are devoured - the last especially during August, when they come in myriads from hop fields, or fruit trees-damsons; and the Flycatchers will clear the gooseberry bushes of the hurtful sawfly. Macgillivray has recorded that he noted a parent bird bring food to the nest five hundred and thirty-seven times during one day! Flycatchers come back to the same nesting place year after year. 
They may take a little fruit from you in the shape of red currants, but this is open to doubt. Like other creatures, a change of diet is, perhaps, valuable to them ; but their labours during the early summer surely entitle them to a share of the fruit." **

The Spotted Flycatcher is a little grey bird, smaller than the sparrow. The upper side of its body is mouse-colour, the underside whitish : on the breast and about the eyes are dark specks. The beak is black, flattened out wider at the base; the upper half of it furnished with stiff bristles on each side of the base to prevent its prey escaping. Legs black and weak; eyes dark and bright. The nest is usually built in trees, stumps of boughs, near the trunk, also in holes, but never very deep ones: It is beautifully woven, of fine moss, lichens, fine rootlets and grass, and is lined with wool, feathers and horsehair. It contains five eggs of light grey-green, with dark marble-like veining and specks of rust-colour; the speckling is sometimes thicker in a ring round the larger end.

* "Birds in their Seasons." 


\section{The Pied Flycatcher. (Muscicapa atricapilla.)}

The male Pied Flycatcher is so strikingly marked a bird that he is almost dazzling to the eye. Yet he is only in black and white, but his markings are very decided. The female is more quietly feathered, the frontlet, wing-patches and under parts are a buffishwhite, whilst her upper parts are olive-green. The bill is just like that of its congener already described. The nest is made in a hole in some tree, of dry grass, moss and rootlets with a lining of hair.

This species prefers warmer districts, where it remains chiefly in leafy woods. The bird is a charming little object as it disports itself amongst the young green of oak and beech woods. When on the lookout for its prey it prefers to perch on some old withered tree branch. And so gentle and small it looks one would not dream of its injuring a fly. Yet, for the great benefit of the woods, it is keen in pursuit of flies, gnats and other " small deer." It will agitate its little wings in front of the larger hollows in old trees, so as to create a slight wind which will rouse and bring out lurking insects to become the prey of this disturber of their peace. In the high beech woods this Flycatcher pounces on the little insects that play in the rays of sunlight that filter through the openings between the branches. A beautiful bird this and well deserving protection.

In Great Britain this species is far less numerous than its congener. It is, however, a regular visitor to some of our counties. Its song is like that of the Redstart. 
USEFUL,

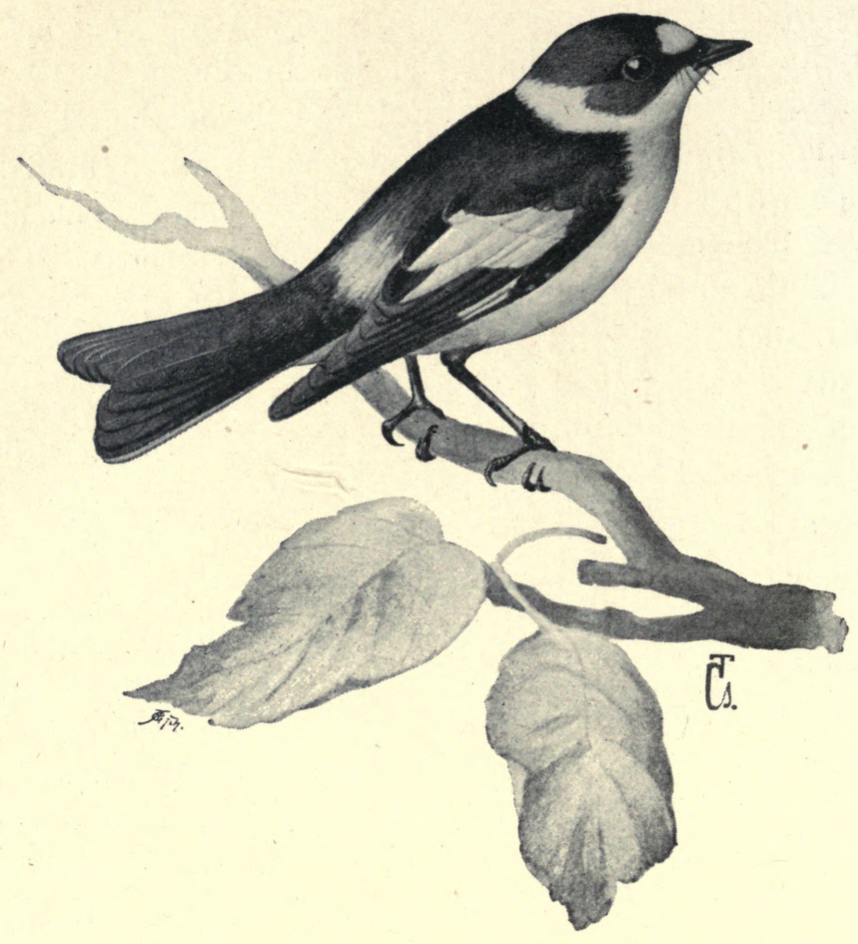

THE PIED FLYCATCHER. 


\section{The Wheatear.}

(Saxicola onánthé.)

THIS is a lively and vigilant bird. It selects a district, to which it afterwards remains faithful. It likes fallow ground, stony hollows, marsh-land, sandy depressions where there are undulations, also meadows where there are grass-grown mole-hills or grass plots. From one of these small eminences it surveys the surrounding land, and on seeing prey instantly makes for it, and having caught it flies on to another stone or hillock. - It also perches on low posts, but only takes to a tree in case of need. As it prefers to be in the open, it is often visible, for when it begins to fly it spreads out its tail and the white feathers at once attract attention. It is a very useful bird, for it lives entirely upon grubs and insects. In autumn it destroys the caterpillars of the white cabbage butterfly. The modest little song is not heard only from the hillocks and stones on which it perches, but also high up in the air when wooing his bride with sweet sounds. It is fairly common in Hungary.

About the middle of March the Wheatear, with its graceful motions, begins to arrive in numbers on our own Southern and Eastern coasts. It flits over downs and fallow lands, some pairs remaining to make nests in old rabbit holes, and in sandy warrens near the coast, others passing on after a brief rest, seeking higher latitudes - the rocky moorlands of the Peak, the fallows of 
USEFUL.

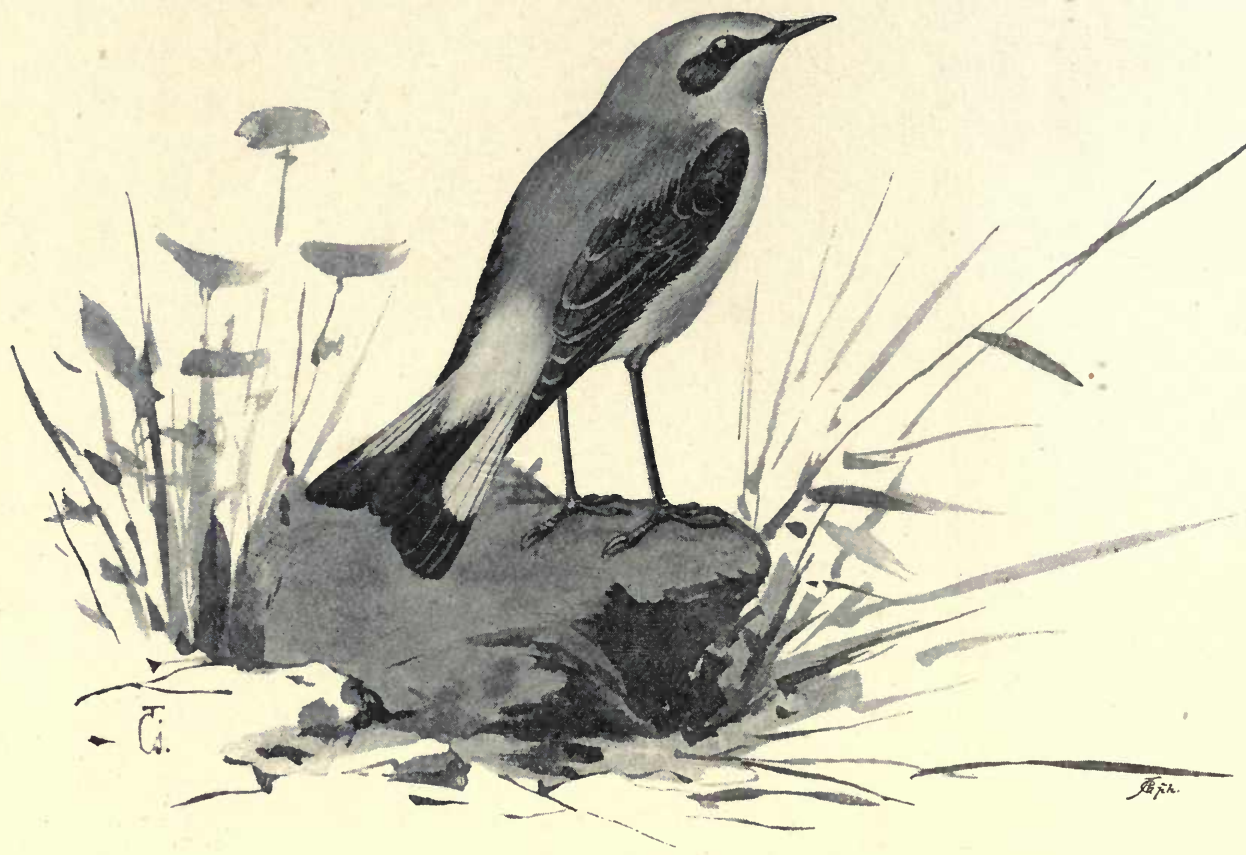

THE WHEATEAR. 
agricultural districts in the Midlands, the mountains of Scotland. The old hole of a Sand-martin in a railway cutting, a crevice in a stone wall, the lee side of a boulder stone, or merely the shelter of a clod of earth in a fallow field serves his purpose. As regards a nesting site, the Wheatear is exceedingly adaptable, suiting himself to the locality. And so the popular names given to this bird seem often misleading to a student of its life-history. In the Southern counties as the "Fallow Chat" it is best known, in Lancashire and Derbyshire it is " Walltack," " Stonecheek," " Stone-smack," or "Smutch " : and this in Staffordshire is "Stone Smasher." But tack and cheek and smutch all come from the bird's sharp note " Chack, chack!' uttered as it flits from stone to stone on high land or along the wind-swept downs and warrens.

Steinschmätzer is the German name for the Wheatear; so the Lancashire name of Stonesmatch is decidedly Saxon. Schmatzen is to kiss heartily - to give a good smack in fact. The French name for this bird, Traquet, was given because of the continual movement of the wings and tail, which is compared to the traquet, or clapper of mills, which is kept in motion by the wind or by the water.

All works on natural history describe the beautiful Wheatear as always wary and shy to a degree, and chiefly, as we have already said, to be found on warrens and poor lands near the coast, but as being especially plentiful about our South Downs. In other districts, too, it frequents the open ground and rough hillocky pastures. But who would look for the Wheatear amongst the old slag-heaps, in the very heart of the 
North Staffordshire Potteries? where, too, the bird seems to lay aside its shy and wary little manœuvres.

Mr. Wells Bladen, the well-known Staffordshire ornithologist, reports on the Wheatear, which arrived earlier than usual, telling us that he saw one on a slagheap at Etruria on March 3rd. In April again he witnessed the curious sight of five Wheatears, mobbing a Kestrel on their slag-heap and driving off the intruder quickly. In June there were at least a dozen of these birds frequenting the heap, and one pair had nested within twenty feet of a very busy railway siding. The nest, with its lovely pale blue eggs, was in a hole in a bank of fused clinkers, two feet from the ground. The eggs were hatched safely, but the young birds were unfortunately killed by some mischievous person before they were old enough to leave the nest. It was a pity the bird made its nest so near the ground, for, as a rule the great heaps which railway passengers between Stoke and Crewe have seen and wondered at, by night as well as by day, are little interfered with, or trespassed on. The dreary slag-heaps in the neighbourhood of blastfurnaces would appear to be spots equally unattractive to man and beast, and especially so to that brightly marked migrant the Wheatear, as it is known on the sunny, wind-swept downs and sandhills near the sea. In August again, one was seen on a railway waggon.

Wheatears leave us by the beginning of October, but now and again a few stray birds are said to winter here in mild districts.

The Wheatear has the crown, back of the head and back a beautiful ashen-grey; throat a faint buffish-white. There is a black stripe from the bill to the eye, which broadens out towards the ear. Underparts nearly white, 
breast yellowish. The side feathers of the wings are white towards the base -at the end black; the middle feathers entirely black. Bill awl-shaped, and, like the legs, black. The female bird and the young are less varied in colour. The Wheatear hides its nest away in heaps of stones, and crevices of the earth, and is most discreet as a rule in ensuring its safety. It lays five eggs, occasionally seven, which are usually of a uniform paleblue colour, sometimes faintly dotted. 


\section{USEFUL.}

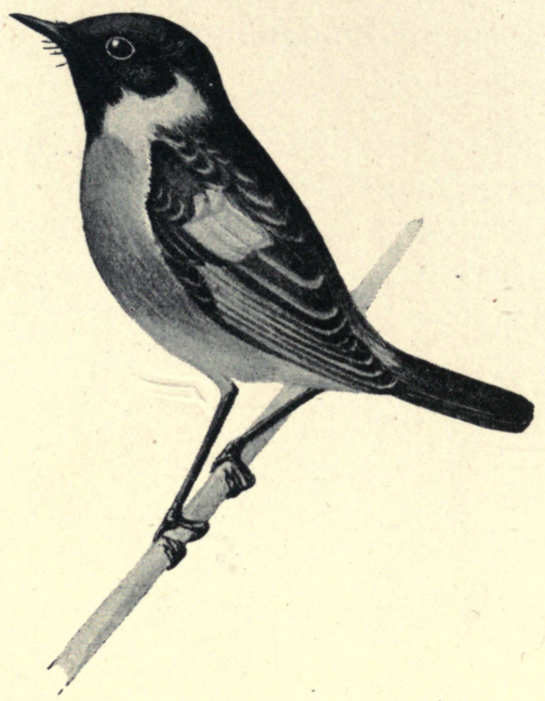

THE STONECHAT. 
The Stonechat.

(Pratíncola rubicola.)

This lively little bird-that is the male bird-has the following characteristics : head, throat, nape, and back black. A conspicuous white patch on the wing-coverts. Under wing-coverts and axillaries black and white. Bill small and awl-shaped, legs and feet black.

It hides its nest so well, that it is difficult to find. It is usually built on the ground in a slight dip, so that the heads of the fledglings are level with the surface of the ground, and thus it merges into its surroundings. Five bluish grey eggs, speckled with brown, are usually found in the nest.

The Stonechat is a very pleasant bird, that seems, wherever it may be, to live by itself. It always sits on the topmost part of a bush, and thence looks attentively on to the ground, yet is quite conscious of all the insects and chafers flying about, for it is an alert captor. Sometimes it looks as if it were turning a summersault in the air, which is always a sign that it has disturbed a beetle in its flight and snapped him up.

This little Black-throat is more a bird of the foothills, where it loves the rocky dips where a few bushes render these not quite bare. It will suddenly appear on the top of a bush, the point of a moth-mullein or a nettlealways on a high perch - gives one look round, swallows an insect, and disappears as if by magic. Soon after it will appear in another spot, and go through the same performance. Meanwhile it wags its little tail, spread- 
ing it out. Late in the autumn, before its migration, it comes nearer to human dwellings, and carries on its pursuit of insects, among the hedges. It even ventures into the kitchen garden, where the cabbage stumps, and vegetable stalks are a favourable position, from which it can easily secure its prey. Its song is clear, pleasing, but not loud. Its call is "Weet, weet, weet-tek, tek, tek."

The birds arrive in Hungary singly.

In Great Britain the Stonechat is a resident in most parts, although such as have bred in the colder districts migrate to more sheltered places in winter. At that season we have a number of arrivals from such parts of the Continent as are too cold for these birds to remain in. Grubs, worms, insects, and beetles are its chief diet, to which it adds a few small seeds. A very destructive insect which they take is known as the Bean Weevil. It is about a quarter of an inch in length; and it finds lodging among the whins, which the Chat family frequent. This beetle also haunts the rhubarb flowers in our gardens and visits the peas, selecting, it is said, always the finest of these in which to lay her eggs. Daddy-longlegs, cattle-flies, wire-worms, small snails, and slugs are also eaten by the Chats-especially the Whinchat, Pratincola rubétra, which comes to the South in middle of April, reaching the North early in May. It has a long white streak over the eye, which is a distinguishing feature of this species, also its underparts are buff, turning to bright fawn colour on the breast and throat. The crown and upper parts are mottled equally with sandy-buff and dark brown. Its bill is less delicate than that of the Stonechat. 


\section{The Bearded Tit or Reedling. \\ (Panurus biármicus:)}

The Bearded Tit is the ornament of the Reed-lands. Its feathers being unusually fine and light, the brilliant black moustache gives it all the more charming and attractive an appearance. It usually slips round in the high reeds. about which it clambers very cleverly. The nest is placed between the stalks of the reeds, and is composed chiefly of their leaves, the colour of which harmonises with that of the bird's long tail, so that the latter, which stands out of the nest, cannot be distinguished from its. surroundings. The clutch consists of five to seven eggs, which have light brown specks and stripes on a white ground.

With the disappearance of the reeds. the number of the birds diminishes.

That is why we have not in England so many of this lovely species as we used to have. Our fens and meres in Lincoln, Huntingdon, and Cambridge Shires, as well as in Kent, Sussex, and Essex, also in Suffolk having been drained, the birds that lived in these have naturally left them. We are glad, however, to know that Bearded Tits are increasing again in the Norfolk Broads, owing to protection from the greed of private collectors. The great naturalist, Buffon, declared that the male bird has the charming habit of covering his mate with his wings to protect her alike from unkind winds and the burning heat of the sun, as she sits on her nest. Trinkin, the peasants of Anjon call it because of the metallic tone of its cry. In the Norfolk Broads it has been known as the Reed Pheasant. Scientists have 
found that this species differs in its digestive organs and other points from the Titmouse family, and that it is, as the late Professor Newton remarks, a perfectly distinct form, representing the family Panuridæ, instead of forming one species of the Paridæ.

It feeds on the seeds of the reeds in winter and in summer on small molluscs.

This bird, which is a beautiful and delightful bird in every respect, is the size of a Yellow-Hammer. Its feathers are of a silky fineness. The head is bluishgrey; from the corner of the mouth on each side, hangs a pointed, silky black moustache, which can be raised erect on occasion. The nape and back are cinnamon brown, which is lighter over the root of the tail; the tail is deep black underneath, and is wedge-shaped with feathers of graduated length. The wings are striped with buffish-white, black and rufous; the quills are brown with white outer borders. The throat and chest are snow white, the under parts white with a flush of rose colour at the sides. The pupil of the eye is golden yellow.*

* In " Home-Life of Marsh Birds," Miss Emma Turner gives a most interesting account of these lovely little birds, illustrated from her own photographs. 
The Great Titmouse.

\section{(Parus major.)}

IN respect to usefulness and activity, this bird takes the foremost place among the Tits: restless, noisy, and always cheerful from morning to night. It clings to the end of the twigs, head downwards, to look for insects underneath the buds; it even climbs up walls if they are rough and uneven. It slips into holes and crevices which seem impossible of entry. It pursues insects everywhere, and swallows them wholesale, as though it could never be satisfied. It has no fear of men, but comes confidently under the roof and perches on the gate, or looks in at the window from the window sill. It is courageous, even bold, and boundlessly inquisitive, a trait which often places its life and liberty in peril. For the sake of a little fat it will allow itself to be snared in a gourd or other trap. But it is just these qualities that make it so popular.

Its voice sounds like " $t z i t$ " or " sitzida, sitzida." This beautiful, kindly bird deserves every protection.

Our sympathies are quite with this bright active creature, although some of our English naturalists accuse it of using its strong beak in order to split the skull of small weakly birds so as to feast on their brains. It has even been known to treat a Bat in this manner. We recognise it readily in the early spring by its note which is like the noise caused by the sharpening of a saw with a file.

Two years ago I saw the largest company of Tits-Great Tits, Blue Tits, Coal Tits, Marsh Tits and Crested 
USEFUL.

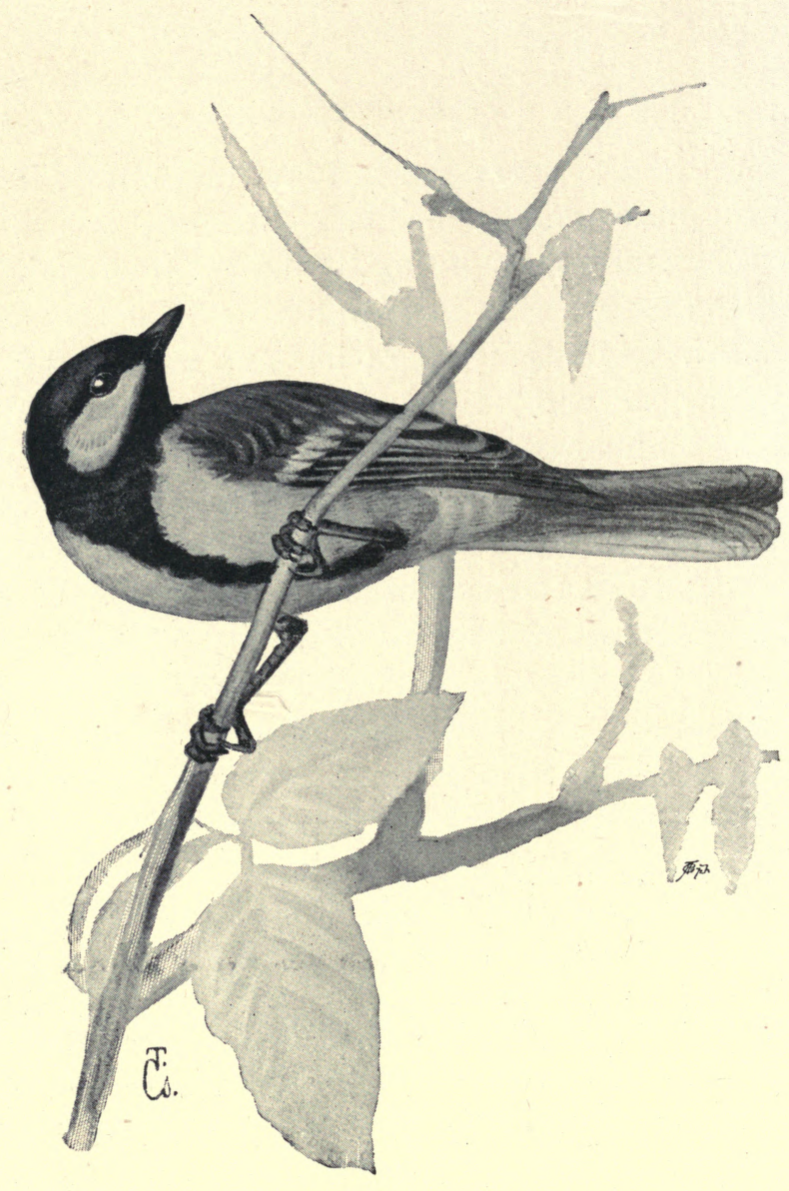

THE GREAT TITMOUSE. 
Tits - together with a great number of tiny and beautiful gold-crested Wrens, that I have ever seen, or indeed can ever hope to see again. It was in a pine forest about twenty miles north of Gotha, the property of Hans Freiherr von Berlepsch, Germany's most ardent bird protector. He was with us at the time and he said even he had never seen the like before, nor had his chief gamekeeper, who is himself an ornithologist. It was the more wonderful because we had walked for nearly three hours through the woods that morning and had seen, with this great exception, little wild life beyond an occasional black Squirrel and, through an avenue of pines from afar, a grand Buck feeding in a clearing. It was in the late autumn.

Nearly three thousand nesting-boxes have been fixed in the trees there, and it was about one of these, a deep one, that a number of Tits had appropriated as a warm and secure sleeping place for the autumn and winter, that the birds - three hundred of them at least the gamekeeper declared-had gathered; now pouncing down on it, a dozen of them at a time, now settling in noisy zi-zi-zi-ing parties on the high branches of pine round this centre. Perhaps, like Rooks that quarrel over a desirable nesting site, they were all eager to secure specially desirable sleeping quarters. Tits and Wrens do, of course, always go about the woods in parties, when family cares are over, but on such a scale as this rarely; and so many dainty Golden-Crested Wrens together might not be seen again in a life-time. All the species of the Tit family, excepting the Bearded and the Long-tailed 'Tit were there.

The amount of good these birds do among forest trees is incalculable, not to mention their greatly mis- 
understood labours in ridding the blossoms of our fruit trees of their infesting insect pests. Tits are, in fact, most energetic and active insect destroyers.

The Great Tit is a lively bird about the size of a Sparrow. The crown, neck, and throat black; cheeks white. A black stripe runs from the throat over the breast and under parts. The mantle is bright green; rump, tail, and wings plum colour, with oblique whitish stripes on the wings. "The under side of the body is a beautiful bright yellow on either side of the black stripe. The short, strong beak is shaped like a grain of wheat and brown in colour; the strong legs are bluish. It builds its nest delicately, and usually in such hollow places as have a narrow opening, sometimes even in empty beehives. - It lays six to nine--sometimes, though rarely, as many as fifteen - eggs, which are finely formed, of a pure white, with speckles of a beautiful rust colour.

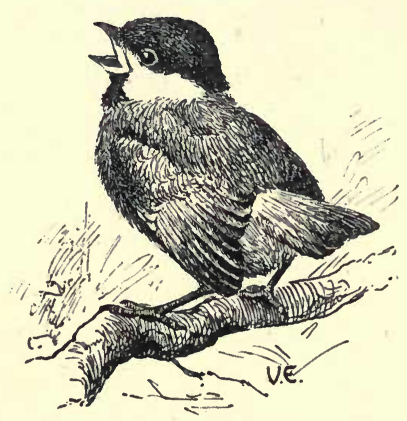

A Tit's Nestling. 
The Blue Titmouse.

(Parus corúleus.)

Crows bright blue, forehead and cheeks white. A dark stripe is drawn from above the eyes towards the nape. The white cheeks are edged at the back and underneath, with black. The under part and rump are sulphuryellow, or rather lemon colour. Tail and wings blue, like the bloom on a ripe plum. There is an oblique white stripe on the wings. The beak is like a little grain of wheat. Legs bluish. The nest is placed in holes of trees with small opening and is composed of soft stuff and is very lightly built. The clutch consists of seven to ten eggs, which are like those of the Great-tit, only much smaller. As many as eighteen eggs have been recorded as being found in one nest.

It is one of the prettiest and most useful birds, and in its actions resembles the other Tits. The number of insects destroyed by these rises into millions, and it has been observed that one pair, in the course of seventeen hours brought food to their young 475 times. Its cry is clear and piercing: "Tgi, tgi, tgi" - or "Ze, ze, zirr," or "Ze, ze, he-he-he-he-he."

It is a real treasure, and not rare in Hungary.

The Blue-tit is one of our best known and best liked British birds. In the autumn great numbers arrive on our east coasts. The Blue-tit, especially, devours a powerful tiny beetle with the ominous name of Scolytus destructor, which works its way from the chrysalis stage at the end of a tunnel bored bv the mother beetle in the tree, until it comes out, after biting a round hole in the 


\section{USEFUL.}

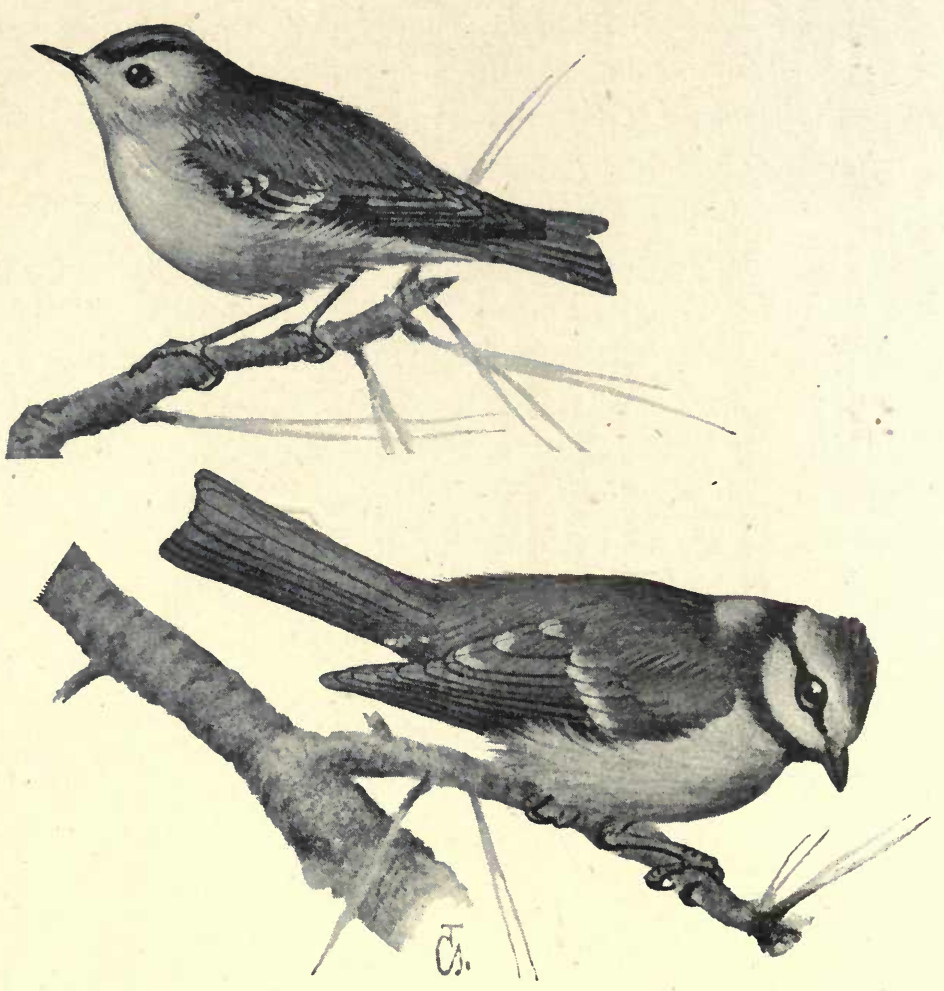

BLUE TITMOUSE. GOLD-CRESTED WREN. 
bark, as a perfect beetle. By this small creature's labours the bark is separated to such an extent from the tree that it cannot live long. A plague of other small wood-boring beetles of like habits destroyed I,500,000 trees in the Harz Forest one season, when the priests even prayed in their churches for relief from this awful pest. And yet there are still numbers of country gardeners who look upon the Blue-tit, especially, as one of their worst enemies.

A house with large grounds in our populous.London suburb is a large boys' school-a private one. One day I saw a pretty sight, one that did credit to the character of the boys there. Between the playground and the cricket field is an iron fence, having a wide gate. For some time this has not been properly closed, and just within the hole in the tubular iron post, into which the fastening bolt ought to run, a pair of Blue-Tits have their nest. As I approached it, a number of gaping mouths were thrust up for food. As the nestlings are fed with aphides and gooseberry moths and the old birds have a large family to feed, and they prey also on grubs and maggots, it is well for the vegetable garden close by.

About sixty boys pass noisily to and fro through this gateway during play-hours, but the wise parents think they know better than to feed them in the sight of these. All is done during school time and early in the morning.

A friend tells me that he knows of a Blue-Tit's nest in an exactly similar position. When the bird was sitting he kicked the bottom of the iron post, and put his finger in the hole. Up flew the bold little creature, hissing like a snake, and bit vigorously at it, fully justifying her rural nickname of Billy-biter. 
I am glad to think that some of my schoolboy neighbours will read this, and will know that their forbearance towards these little birds is appreciated: a forbearance towards the defenceless which is always a distinguishing characteristic of the true gentleman.

The Blue-Tit is of great service to all flower and fruit growers, and it comes much to our suburban, and even London gardens. And yet gardeners at one time persecuted the little labourer, one of the prettiest and most winsome of our common birds.

Sitting in the garden of a house I formerly lived in, I noted there, in my apple trees laden with fruit, that the Tits - the Great, the Marsh, the Coal, and the Blue-Titthat had not been much in evidence since April, when they were busy amongst the blossom buds, have come back, and they were busy now again amid the branches. Having read lately that they destroy the fruit, notably apples, in the autumn, I have watched them closely. It is as I expected: a number of the apples have been attacked by insects, and it is on these that the birds are busy, on fruit which if they did remain on the trees-they are now falling in numbers-would be quite worthless. The Tits enlarge the holes so as to get at the true destroyers, and they are doing more good than harm. As the Rev. F. O. Morris said, long ago, " the destruction of the Blue-tit by the farmer or gardener is an act of economical suicide."

Tits will also sometimes have recourse to the orchard in times of drought, in order to quench their thirst by bites at the fruit. But we should be churlish indeed if we grudged our little unpaid labourers a small tithe of our harvest, which is the larger for their spring services. 


\section{The Golden-Crested Wren.}

$$
\text { (Regulus cristatus.) }
$$

THIS is the very smallest of our British birds, and indeed of all European species. It is found generally throughout Great Britain, and it has increased in the north greatly of late years owing to the greater cultivation of larch and fir-trees. The numbers of these Wrens are augmented often in autumn by great flocks that come to our eastern coast from the Continent. A migration wave of this sort, Mr. Howard Saunders told of, which lasted 92 days, and reached from the Channel to the Faroe Islands. Another migration in 1883 lasted 82 days, and one, the following year, 87 days. On such occasions bushes in gardens on the coast are covered with birds as with a swarm of bees; crowds flutter round the lighthouse lanterns, and often come to grief there, and weary little travellers climb about the rigging of fishing-smacks in the North Sea.

The Golden-Crested Wren is even smaller than the Common Wren, but its feathers are more flossy. It has on its crown a tongue-shaped patch of warm saffron yellow edged with black. The whole of the rest of its coat is of a plain greenish gray, which is lighter on the under parts of his body. The colour of the wings is also sober, the feathers having a lighter edge; the little beak is thin and pointed, the legs nearly black. The cunningly built nest is placed in the fir-trees where it can with difficulty be discovered. The eggs, which number six, occasionally eleven - of the size of peas--are 


\section{I4 THE GOLDEN-CRESTED WREN}

reddish speckled with a darker shade of the same colour. This useful little bird, always active, hopping unweariedly about seeking food, lives exclusively on insects and grubs. Its dwelling is among pines and fir-trees; it often associates with the Tits, its call is "Sit, sit, sit."

It is not rare, and is worth its weight in gold.

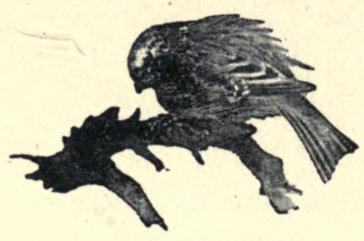


The Crested Titmouse.

(Parus cristátus.)

IN order to learn habits of the Crested Tit it is necessary to climb high into the region of the firwoods. Here the Crested Tit is the good genius of the neighbourhood, for with untiring zeal it hops about among the thick branches of the fir labyrinth and destroys the most mischievous insects. Its call is "ziárrrr" or "zick giuirr." It is not rare in the pine forests of Hungary.

The Crested Tit breeds in a few of the oldest forests in Scotland where firs and oaks remain. In Perthshire it is seen, but to England it is a stranger, a few cases only, being on record. In Ireland also it is practically unknown.

The Crested Titmouse is much smaller than the Great Tit or Oxeye. It is easily recognised by its pointed head, which resembles that of the Crested Lark. The feathers of this are black, edged with white; the cheeks white; throat and round the ears black; so that the head has the appearance of being framed. Wings and tail greyish-brown, the feathers with whitish edges. Underneath it is a dingy white, rust colour at the sides. Its nest is carefully built, in holes and in trees. It lays from five to eight, sometimes ten, white eggs speckled with light rust colour. Two broods are generally brought out in the season.

These birds are seen in Germany, and elsewhere on the Continent, frequently in company with Goldencrested Wrens, other Tits and also Tree-creepers. 
USEFUL.

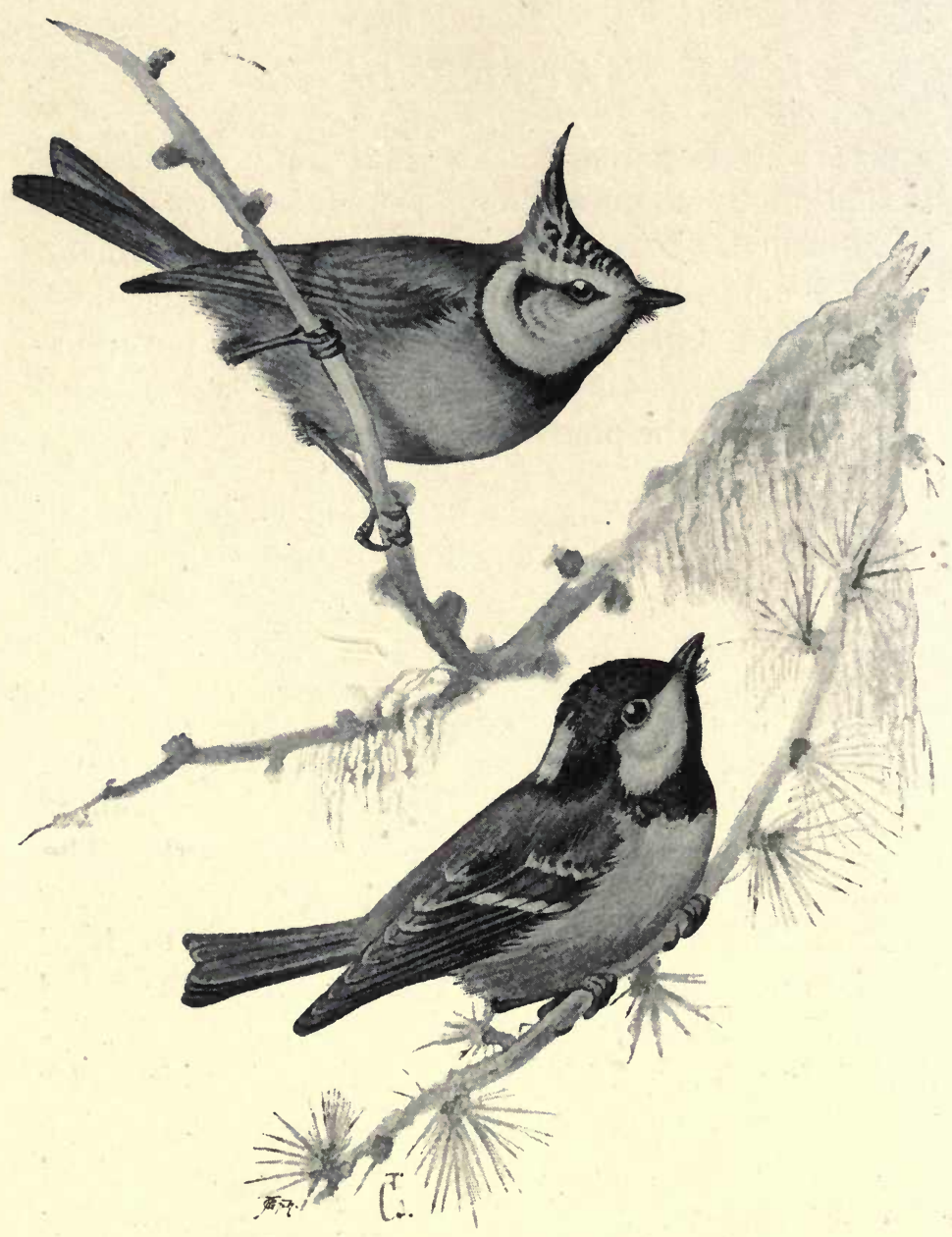

CRESTED TITMOUSE. COAL-TITMOUSE

- 


\section{The Coal-Tit.}

\section{(Parus ater.)}

This lively, pretty, amiable bird, also lives in the thickest parts of the fir woods, where it carries on its work of destroying the injurious insects, the number of which is enormous. It used to be thought that the CoalTit did harm to the young buds; but this has never been authenticated, and even if it does break one off here and there, the mischief is small indeed, in comparison with the service it performs from one year's end to the other. Its call is shrill and clear "ziwih, ziwih, ziwih," or "sitt, sitt" - or a long-drawn "seeb, seeb."

This bird occurs in considerable numbers in Hungary.

The Coal-Titmouse is one of our common birds in the United Kingdom and it is said to increase yearly, although it is not yet so common as the Great and the Blue Tits. It is a very useful little bird as it feeds its young largely on green caterpillars; but it eats nuts as well as seeds - the seeds of the Scotch fir it is specially fond of.

The Marsh-Titmouse-Parus palustris-is another resident species in Great Britain, but it is, with the exception of the Crested Titmouse, the least common of our Tits. I have seen it much about our Middlesex gardens, a superficial observer can note the difference between this bird and the Coal-Tit easily because the Marsh-Tit has not the white patch on the back of the head which the Coal-Tit has. It is often seen in orchards where it does good service, but is fond of the neighbour- 
hood of rivers and delights itself among the alder trees and pollarded willows of swampy ground.

The Coal Tit is the same size as the Crested Tit. Cheeks white - at the back of the head a white patch, the rest of the head black, so that this colour forms a broad bridle, which recalls that of the great tit. Underneath it is of a dingy white, the mantle a bluish ash-colour with a tinge of green. Wings and tail dark grey, the former having two oblique whitish stripes. The nest is built on the ground, in holes in fir trees under decaying bark, sometimes in holes in the ground-and is formed for the most part of green moss, the interior being warmly lined with hair. The clutch consists of six-sometimes even ten-eggs of a brilliant white finely speckled with rust-colour. 


\section{The Long-TaILed Tit.}

\section{(Acredula caudáta.)}

THIS is a true Tit, and never rests, but is hunting here and there, slipping in and out, in constant movement, from morning till night, now and then indulging in such gymnastic exercises on the frailest twigs, as would by comparison made the limb-dislocating mountebank look a clumsy lout. Nothing can be more charming than the society of which the Long-tailed Tit is the grand master. It comprehends the Great-Tit, the Blue-Tit, and the Coal-Tit, one or two tree runners, Spotted Woodpeckers and a Nuthatch. The whole form a brigade of workers, who rove through the woods and gardens, each one working according to the measure of its strength. They search a tree, from the bark to the point of the thin topmost twig, where the Long-Tailed one is quite at home, so light a featherweight is his body-the twig bends, but does not break, and the tail acts as its balancing pole. This society gathers at the same hour at the same place, in the late autumn, in order to seek fresh places. The note of the Long-Tailed Tit sounds like " je, je, je," and "gey, gey, gey, gey." It lives on injurious insects, and wherever it builds its nest in wood or garden it is a priceless treasure.

It is not rare in Hungary, and deserves to be protected.

There are various forms of the Long-tailed Titmouse in Europe; our own form is fairly common in localities which suit its mode of living. It is resident and common in Ireland, but very local in its occurrence in Scotland. These Tits often rear two broods in a season, and afterwards the whole family may be seen flitting about 
USEFUL.

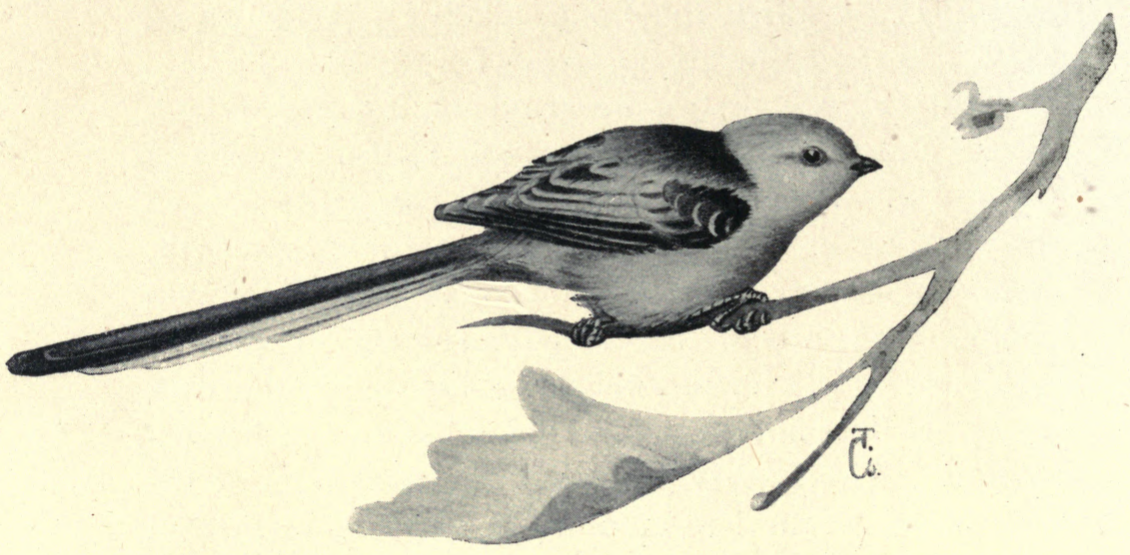

LONG-TAILED TIT. 
together, in single file from hedgerow to hedgerow. There is a dipping motion in their flight which is pretty to watch. All these feed on insects and their larvæ. The Long-tailed Tit is the size of the Wren; a roundheaded little bird with a tiny beak, and a very long tail. The head is white, and suggests that of a grey-headed old grandfather. The fore-part of the back is black with white patches on the shoulders, the tail black, the three outer feathers being for the most part white, and graduated in length, the two middle feathers being shorter. The under part is rose colour; the tiny beak black.

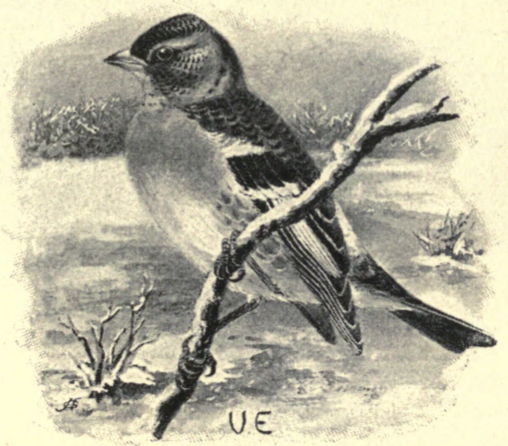

A bright winter friend. 


\section{The Nest of the Long-tailed Tit.}

IT is not only in our latitudes that the nest of the Longtailed Tit is considered a masterpiece, but even far away south where nature works such marvels, where the little humming birds, scarcely bigger than the joint of a child's

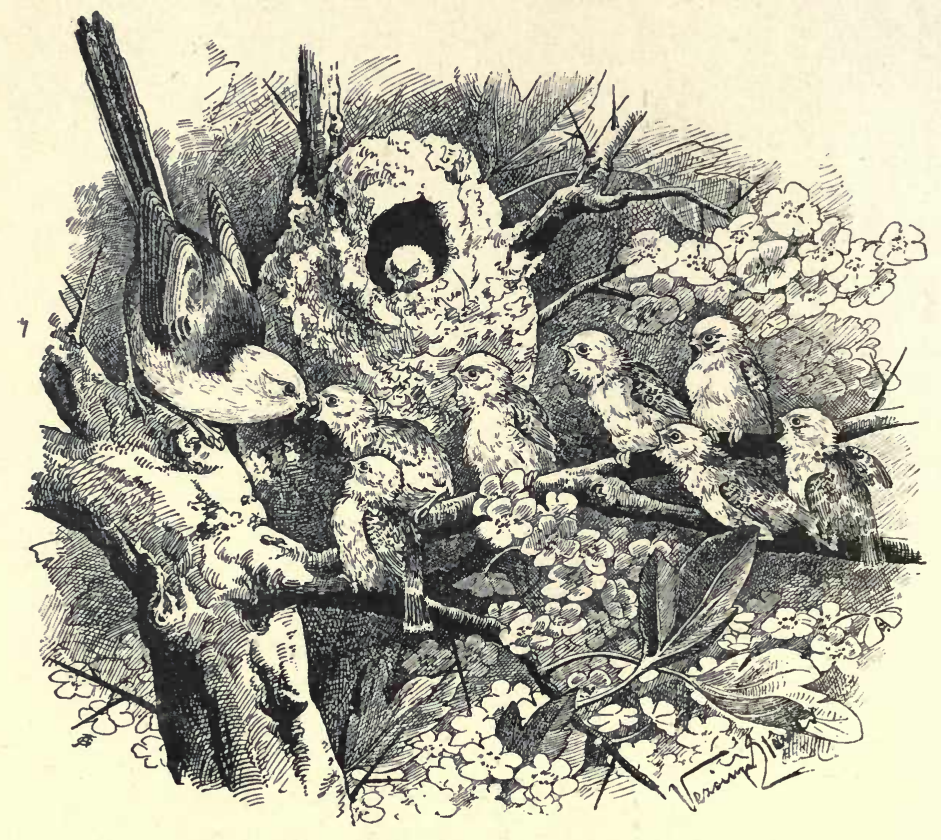

\section{LONG-TAILED TITS AND FAMILY.}

finger, shine in the sunlight like diamonds and rubies, and build nests no bigger than half a small hen's egg,even there, this nest is looked upon one of the finest specimens of bird architecture. It is the most charming, most beautiful, and warmest bird abode. Most often it is round, the twigs supporting it like the fingers of the 
hand, and often it stands free like a little beehive. It is beautifully roofed in with a domed top, and has at the side an opening large enough for a big bumble bee. It is constructed of the finest moss, and the softest fluff from the meadows and poplars; it is soft, and yet so strongly put together that no human workman can imitate it.

In this soft, warm nest the tiny bird lays its nine, sometimes eleven, eggs. These are white with rosecoloured spots at the thicker end. The male and female birds sit alternately on the eggs for fourteen days; and then the hard work begins - twelve babes to nourish, and with the finest food!

The industry of the Swallow is truly great, but that of the Long-tailed Tit is still greater. The Swallow seizes its booty while on the wing, and has only to open its beak; but the Tit has to go from branch to branch, working sometimes head downwards, sometimes swinging, in order to secure the tiny morsels.

Truly he who does not delight in the sight of this tiny family united by love, who is not moved when the twelve baby birds are seen sitting close pressed together on a slender bough, and the little parents come and go, with their continuous cry, bringing food and giving it in turn to the young ones-he whom such a sight does not fill with pleasure, must have a stone in his breast instead of a heart. 
MUST BE. KEPT IN CHECK.

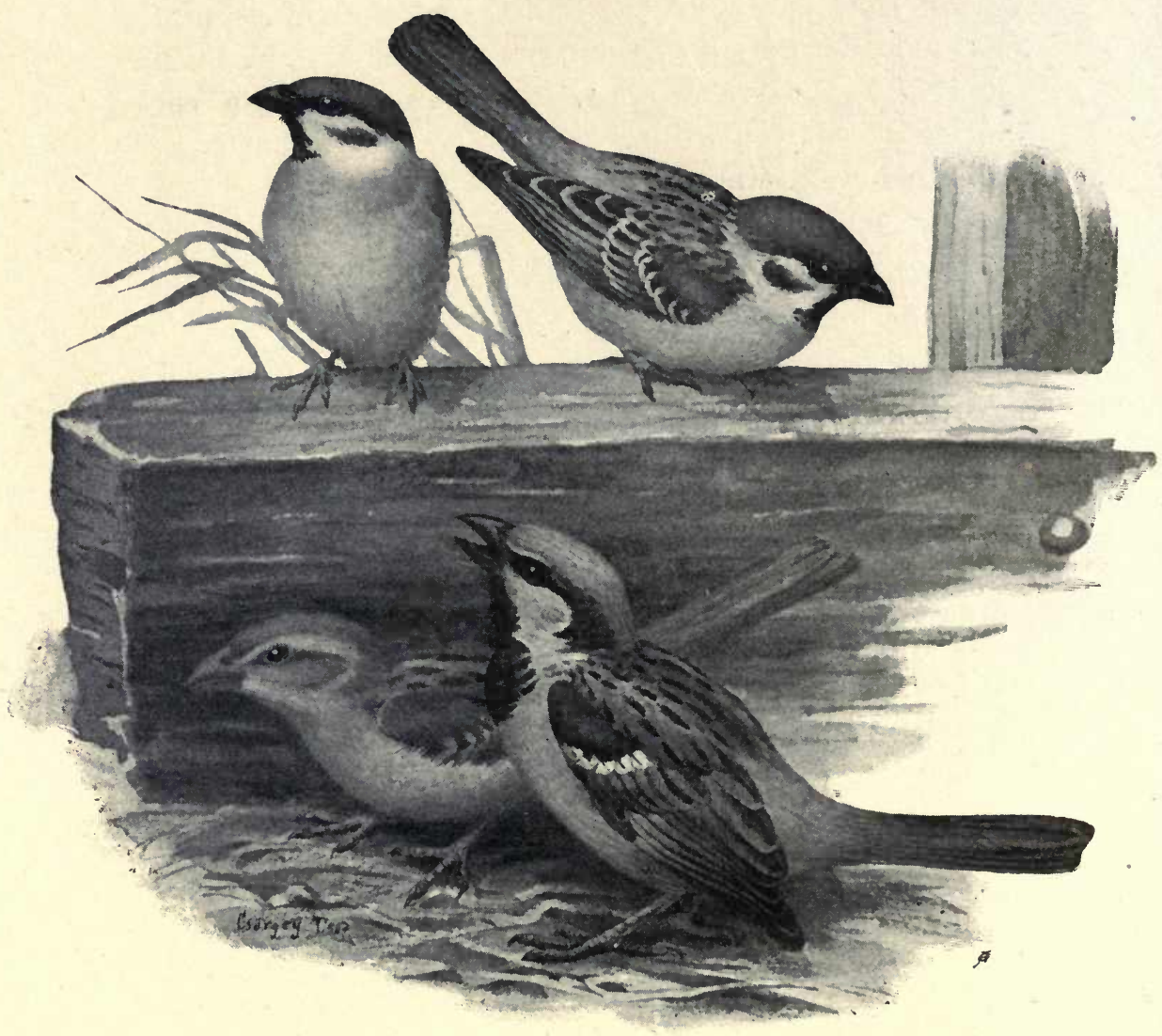

THF TREE SPARROW.

THE HOUSE SPARROW. 


\section{CHAPTER VI.}

\section{WORKERS ALL THE YEAR ROUND.}

\section{The House Sparrow. (Passer domesticus.)}

THIs is among birds what the street-boy is in the townsmerry, audacious, obtrusive and quarrelsome, always moving and picking up what it can. A human habitation without Sparrows is inconceivable. In the street it rummages in the tracks of the horses; in the markets, it sees when the stall-keeper is dozing, and helps itself out of her basket to anything that takes its fancy.

When the wheat ears are soft it betakes itself to the fields and fills its stomach and also feeds its young with their milky juice; when the corn is ripe he attacks it and knocks more grains out of the ears than it can possibly eat. It does the same with cherries, mulberries, and all kinds of seeds. It also breaks off young buds and the points of young shoots.

It drags the Titmice out of their nest-holes and establishes itself there. It presence is easy to recognise by the straws sticking out of the hole. The only method of preventing this is to make the entrance-hole narrower and to hang the nest-hole lower down.

It is true that when there is a great abundance of cockchafers it consumes a great quantity of these creatures; but as soon as it finds something it likes 
better, and is easily obtained, he leaves the destructive chafers to others. The most useful service it does is in severe snowy winters, when, in company with a large number of other Sparrows, it scours the fields and picks up the seeds of noxious weeds; besides this it feeds its young with insects. It should not be suffered to increase too much, for it does on the whole considerable mischief. The humane way of lessening its numbers, as we have before pointed out, is to pull down the nest wherever we can.

A word for our English Sparrows. E. Newman, F.Z.S., says : "A Sparrow-hawk left to himself, even by scaring the Sparrow from ripe grain, will save the wages of at least ten boys." And the head gardener. of a large garden which was protected with a network of black cotton only, said: " Nobody knows what good a Sparrow does in a garden. In fields it eats charlock, chickweed, plaintain, buttercup, knot-grass," etc. When the hay lies in swathes in the fields it haunts them in quest of what are called "haychaffers" ; craneflies, earwigs, blight, etc., are part of its prey. "They have been known," writes Curtis of Sparrows in " Farm Insects," " to gorge themselves with the larvæ of the May-bug till they were unable to fly." A French writer says: " Under one Sparrow's nest the rejected wing-cases of cockchafers were picked up; they numbered over I,400. Thus one pair had destroyed more than 700 insects to feed one brood." Much of the harm attributed to Sparrows is the work of a small Weevil, which is very destructive to many kitchen-garden plants. $\mathrm{Mr}$. Joseph Nunn of Royston, a farmer, writing of the Sparrow during I897, says that Sparrows do not eat 
more corn from the stacks than other Finches or the Buntings, and that a farmer must learn how to protect his property the same as any other tradesman.

As to its colour, we may say that its crown is grey with chestnut stripes, throat black--that is, the male bird. The throat of the female is whitish, and there are whitish lines on the head and over the eyes. Beak strong, wedge-shaped, pointed. The whole bird suggests strength. It lays five or six eggs, which are white, thickly speckled with dark marks. The nest is composed of straw, wood, tow, hair and feathers carelessly put together, still it is soft and warm. This bird breeds twice a year, sometimes three times. 
The Tree Sparrow.

(Passer Montanus.)

THE habits of this Sparrow vary from those of the house species in that it dwells among fields and foot-hills where wood and thicket alternate. It also frequents gardens, and behaves very audaciously. In hollow places in old trees it is sure to be met with. It is a bold builder, and will place its nest with us in Hungary under the Eagle's eyrie, or the Stork's nest. It may generally be said to be a hole-nester, and a much greater insect eater than its congener the House Sparrow.

Its manner of nesting makes it all the more dangerous to the artificial nest-holes, and we cannot guard them against this species, either by decreasing the size of the entrance or by placing the nest-holes lower; it drags the Tits out and takes possession of the hole; the only thing that can be done is to drive it away with small shot; otherwise we should harbour Tree Sparrows instead of Tits, and, although they are not as numerous as the House Sparrow the supply of them is more than enough.

The Tree Sparrow is also rarer with us in Great Britain than its ubiquitous relative. It is quite local as to habitat. Until quite recently it was unknown in Ireland. Large numbers arrive, however, in autumn along the east coast, and its settlements in Scotland are chiefly on the eastern side, up as far as Sutherland. Its nest with us will be found at times at some distance from human dwellings; in the soft rotten wood of trees often, but it builds also about farm-buildings, beneath roof- 
tilings and in cliffs by the sea. The eggs are more glossy than the House Sparrow's; two and even three broods will be reared in a season. The young are fed on caterpillars and other insects, soft vegetable matter, etc., but in winter both young and old frequent farmyards, and visit the ricks; also they seek grain among horse-droppings in the streets. The illustration shows the difference in the markings of the two species of Sparrow.

This bird is smaller than the House Sparrow, and more slender. The colouring is, on the whole, the same in the male and female birds. From crown to tail it is chestnut brown, passing into ash-grey, with dark markings round the ears and on the throat. Both in colour and demeanour it is a true Sparrow. It lays five or six, occasionally seven, light-coloured speckled eggs. 
USEFUL.

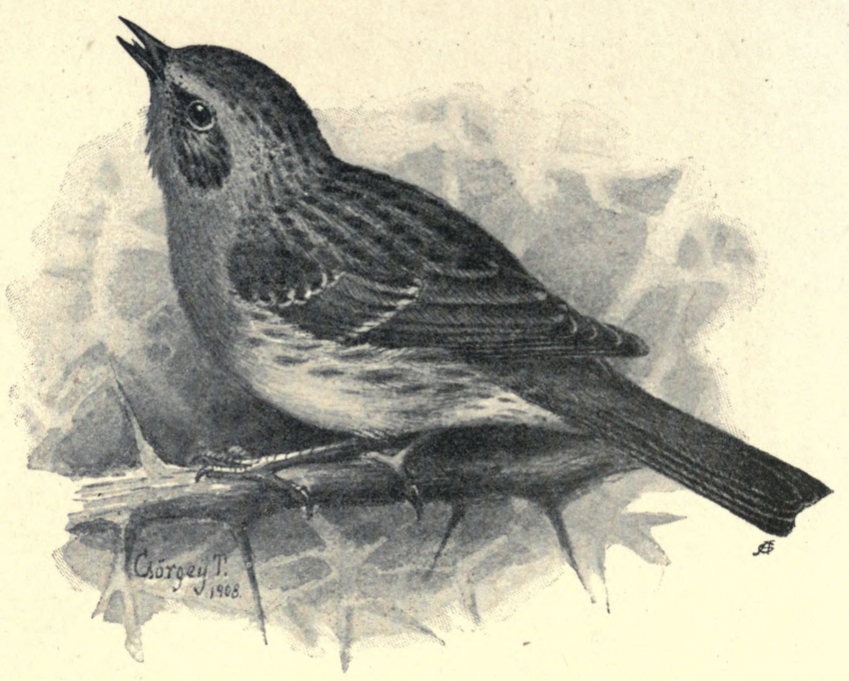

THE HEDGE SPARROW. 
The Hedge Sparrow. (Accentor modularis.)

THis is no vulgar little city arab, picking about in untidy stables, in the refuse on the streets, and among the droppings of horses. Does not its Latin name rather proclaim it one of the aristocrats of bird life. Its dress may be dull-coloured, but its form and its motions are not inelegant, despite its familiar name of "Shufflewings" and "Smokie," in deference to its characteristic motion and its colouring. Head and nape are a bluishgrey, streaked with brown, back and wings are a reddish-brown, streaked blackish; the lower wingcoverts are tipped with clayish colour, in bar-fashion, underparts a dull white; the sides are marked with dark streaks on a pale reddish-brown ground; the bill brown, the base being of a lighter shade; the legs and feet are yellow brown. Length $5 \cdot 5$ inches. The slate-grey on the head and throat is not seen on the young birds, which are browner and more spotted than the adults. This is a friendly bird and very easily tamed, so that it will often bring its mate to the kitchen door for food in winter, and its song is more melodious than many of our singers. The nest is built of moss, bits of stick, roots, and dry grass, in all kinds of hedges, or roadside thickets. The eggs, four to six, greenish-blue without spots and rough in texture. Many bird-lovers refuse to call this bird by the plebian name of Sparrow, with them it is always the Hedge Accentor.

The food of this bird mainly consists of caterpillars, eggs of insects, wood-lice, earwigs, chrysalids, small seeds of weeds, house-refuse, etc. 
USEFUL.

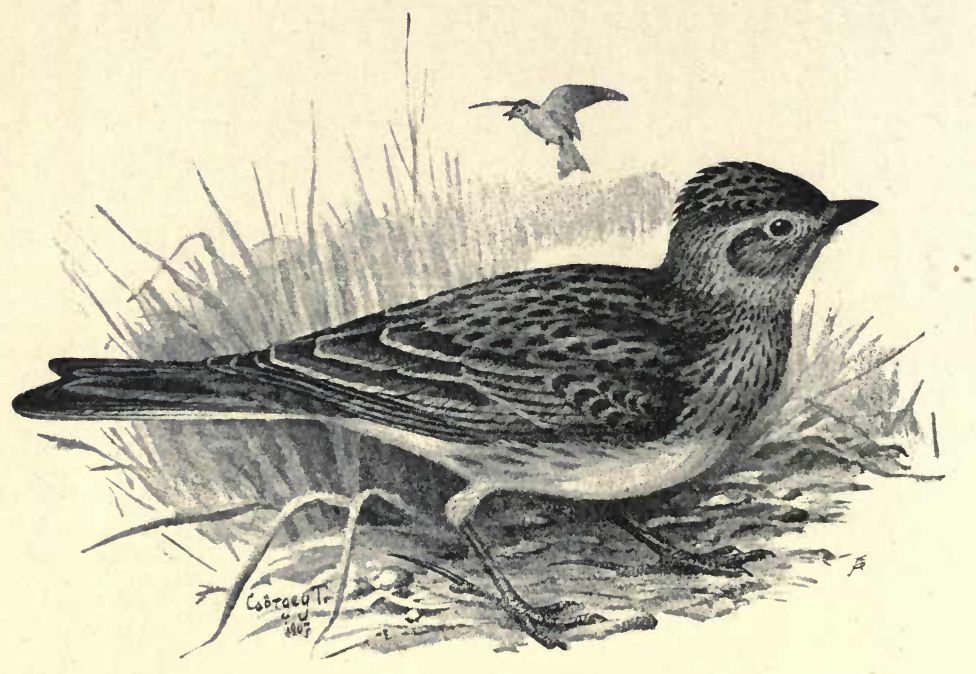

THE SKYLARK. 
The Skylark.

(Alauda arvensis.)

IT can raise a tuft on its head at will. A long, slightly hooked claw is on the back toe. The nest is placed on the ground, more rarely among corn or meadow grass, but rather on fallow ground or clover field, among low thick growth; it assimilates so closely with its surroundings that it is difficult to discover. It usually contains five eggs, which, being of a dingy, grey-green speckled with a darker colour, also somewhat resemble the colour of the earth.

This Lark ocçurs most numerously in the northern regions, and as regards its habits is one of the best known and most popular of birds. It arrives in Hungary early in the spring, settles down, and does not allow any other bird to approach it, pecking them away if possible. Its little territory often occupies only a hundred paces. The different territories are contiguous, and disputes between the neighbours are perpetually going on. The combatants may constantly be seen, darting here and there with lightning speed, flying near the ground, in pursuit of one another. During the pairing and brooding-time the male bird sings unweariedly, flinging his song into the air. He rises towards the sky, with vibrating wings, higher and higher, dropping his ever-changing trilling notes,often rising to such a height that he disappears from sight and the song dies away. Then suddenly he reappears, becomes silent, and drops like a stone to earth.

In his poem " In Winter," Johann Arány says of the Lark :- 
"Like the poor poet.

Who in the sun's bright rays spreads out his wing

And bears towards heaven his song: he turns and falls,

And he is silent."

The Lark lives partly on seeds, but its chief food is gathered from the insect world. It is almost universally considered by epicures a great delicacy, and is snared by thousands. Fortunately it exists in great numbers, but its snaring is to be deprecated.

In England larks have been very largely eaten, but happily the practice is now most strongly opposed by thoughtful people. If the consumption of Larks in our country went on as it was doing a few years ago the species would soon be extinct. Yet this singer-whom poets have delighted to honour and one-possibly because of its alert ways and its sentinel-like attitudewhich Julius Cæasar chose as an emblem for one of his famous legions,-devours wireworms, grubs and various larvæ when these lie hidden in the short winter pastures, and just at the stage when the latter are most greedy of nourishment, so that the grass would suffer incredibly but for the bird's work. A recent authority stated that it was to be deplored that not a tenth part of the Skylarks that formerly frequented the Midland pastures were there now. Unfortunately this bird is a favourite among those who are given to the caging of singing birds.

This bird is bigger and more slender than the Sparrow, and the colouring generally of the upper parts is a warm yellowish-brown. It is distinguished from its congener, the Woodlark, by its tail feathers. The two outermost feathers are white, growing darker only about the shaft. The outer web of the second feather is white. The tail feathers have dark-brown centres and tawny edges. 
The Kingfisher.

(Alcedo ispida.)

The Kingfisher is the arch-enemy of the fish, and it is hardly credible that this relatively small bird, should gulp down, as it does, fish as long as your finger, in order to fill his stomach. It digests very quickly, and spits out the bones, scales, and fins. It watches, from a bough, for the little fish. Where a bush bending over the water undisturbed by the eddy forms a calm mirror,- - there does this resplendent fish-poacher settle itself on an overhanging bough, to watch-motionless and with incredible tenacity-the water and the living things beneath it. If a trout or other small fish, feeling quite safe, comes to the surface, the Kingfisher drops on it like a piece of lead; it grasps its prey with its sharp beak, and, shaking the water from its plumage, flies back to its perch, gulps down its delicate morsel, and sets itself again to watch. Its colour protects the bird when diving. The underparts are much the same colour as a fallen leaf, and this arouses no suspicion in the fish-the-back, on the other hand, shines like the blue shimmer of the running stream, and that often protects the bird from the circling Sparrow-hawk. If it comes to a flat shore on the side of a small stream, which offers no overhanging perching place, it settles on a stake or a clod of earth, and now and then hovers over the water, and flutters like a hawk. It is an inconstant bird. It appears, and disappears from a district, and then, perhaps after some years, presents itself again. Its flight is rapid, and it raises its cry, as it goes, " teet."

It does harm, but is scarce in Hungary. 

In Great Britain it was also becoming scarce, but of late years Bird Protection and the ever increasing number of bird-lovers has been in favour of this beautiful ornament of streams and meadows. It is, however, often shot because its feathers are of value for dressing artificial flies. Personally I could not call a bird hurtful because it seeks the food which its Creator intended it to eat, which is no more the property of man when it is taken in its natural conditions than it is that of the bird, and I confess I would rather see the brilliant blue of the Kingfisher flash up a meadow stream than the angler's figure there with his rod.

The Kingfisher is seven and a half inches long, a short thick set bird, with short tail and straight pointed beak, which sticks out like a lath nail. The colouring of its plumage, which, in its flight, sparkles like precious gems, makes it one of the marvels of nature. Crown, neck, mantle, and rump are of an exquisite brilliant blue; a cinnamon brown stripe passes over the eye, growing lighter as it extends over the side of the neck. Eyes brown, throat white, underparts a brilliant rustred, legs red, rather short, the toes slightly joined at the root. It nests on the banks of rivers and streams, boring in the bank, on a level just above the surface of the water a tunnel a yard long, which it enlarges at the end into a cauldron-shaped cavity. It does not build a nest here, but lays its round white eggs on rejected fishbones. The eggs number six or seven. 
USEFUI..

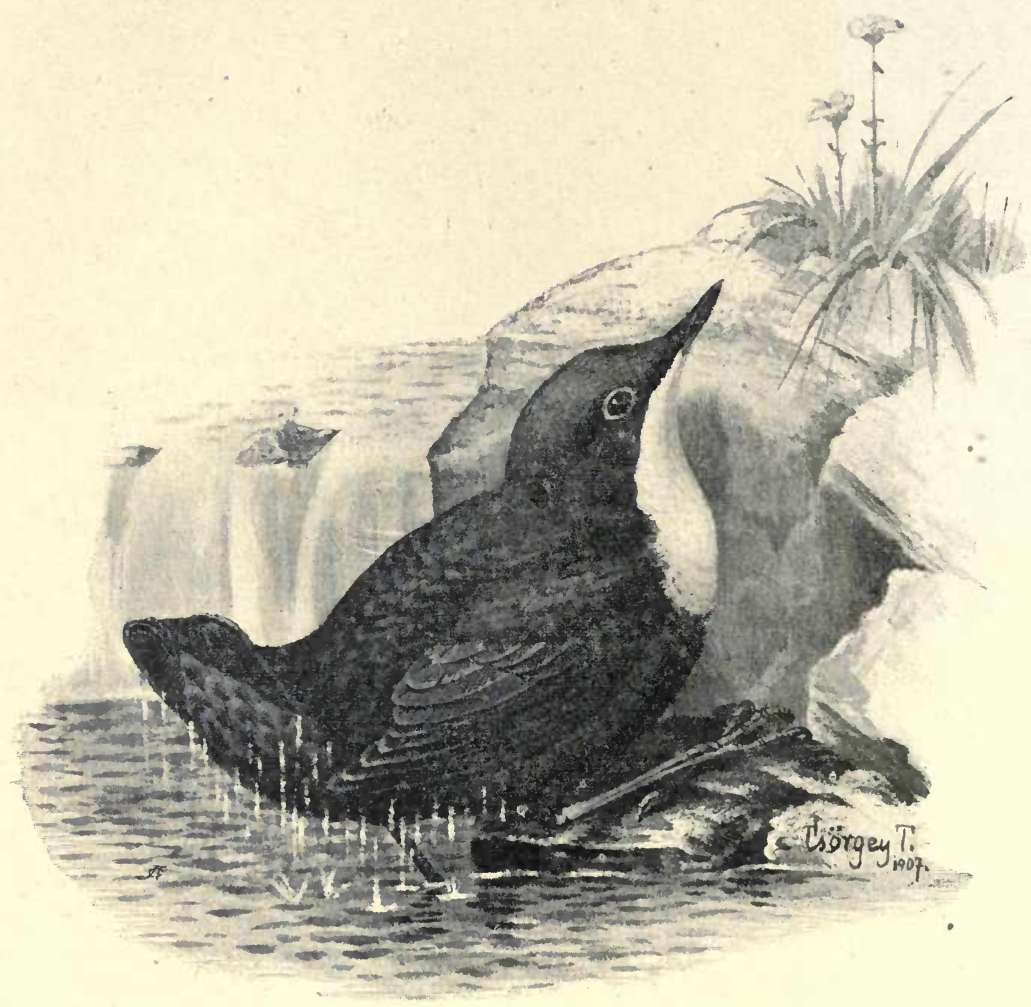

THE DIPPER. 
The Dipper.

(Cinclus aquaticus.)

The Dipper's habits are most interesting. The bird frequents the most picturesque streams, perching on the dry boulders, with the water gurgling and splashing about him. From this he dives and walks under the water, turns over the small pebbles and returns to his stone. This led to his being suspected of being an enemy to the fisherman. It has, however, be proved by the inspection of the contents of the stomachs of several Dippers that only insect remains and small shell-fish were eaten. The fact that he will attach himself to brooks which contain no fish at all, proves that he does not feed on these. The bird's plumage is simply watertight, and therefore admirably adapted to a bird which can swim as well as dive.

The song of the Dipper is strong and cheery; and the lively ways of this Water-ouzel, as it often called, lend a charm to our mountain streams. With us in Hungary a thorough investigation of the life-habits of this bird, which spread over a considerable period, and involved much correspondence, has resulted in the complete vindication of this bird's character.

Mr. Herman's verdict on the Dipper and the Kingfisher, are the more valuable because he is the great authority, in his own country, in all that relates to 
pisciculture. The Dipper remains with us all the year round, especially in the Peak District in Derbyshire, and the hill-streams of North Staffordshire. It is, however, found in the British Islands, wherever there are rapid rivers or stony brooks and streams. All the Highland burns and rivers have a few pairs. In Ireland, too, it is resident in the mountainous districts, but it forsakes these often, at the approach of winter, for the mouths of tidal rivers and the salt flats of the seashore. In the valley of the Dove it remains about the stream all through the winter. The birds are clever in contriving to make so heavy a nest cling to the wall of rock or stone, where it is placed. It cocks up its short tail very much as a Wren does, and dips its head in a way, which has gained for it the quaint local name of " Betty Dowker." As it feeds much on the larvæ of the May-fly and bank-fly, and others which are destructive to the salmon spawning beds, it must be of good service to the fisher. The young birds are able to swim as soon as they leave the nest, and to chase the water insects, using both legs and wings in pursuit. The wings serve as oars. The song of the bird is begun in autumn, and it will often be heard all through the winter, but always in early spring, and fully fledged young have been found by the twenty-first of March.

This is a thick-set but charming bird a little over six inches in length. Head and nape are umber-brown, tail and wing-feathers dark brown; chin, throat, and upper breast white, passing off into chestnut-brown, dark-grey and black on the belly; bill brownish-black, legs and feet brown; upper parts mottled with dark grey and brown. The beak is awl-shaped, and the sharp toes on the strong feet are long and well divided. The nest is 
generally placed close to a running stream, preferably near to, and even behind some little waterfall. It is a large oval ball of leaves, grass, and moss, lined with dry grass and dead leaves. The entrance is low down in the side. From four to six eggs are laid, which are glossy white at first, but become dull as the bird sits. Two broods are reared in a season. 


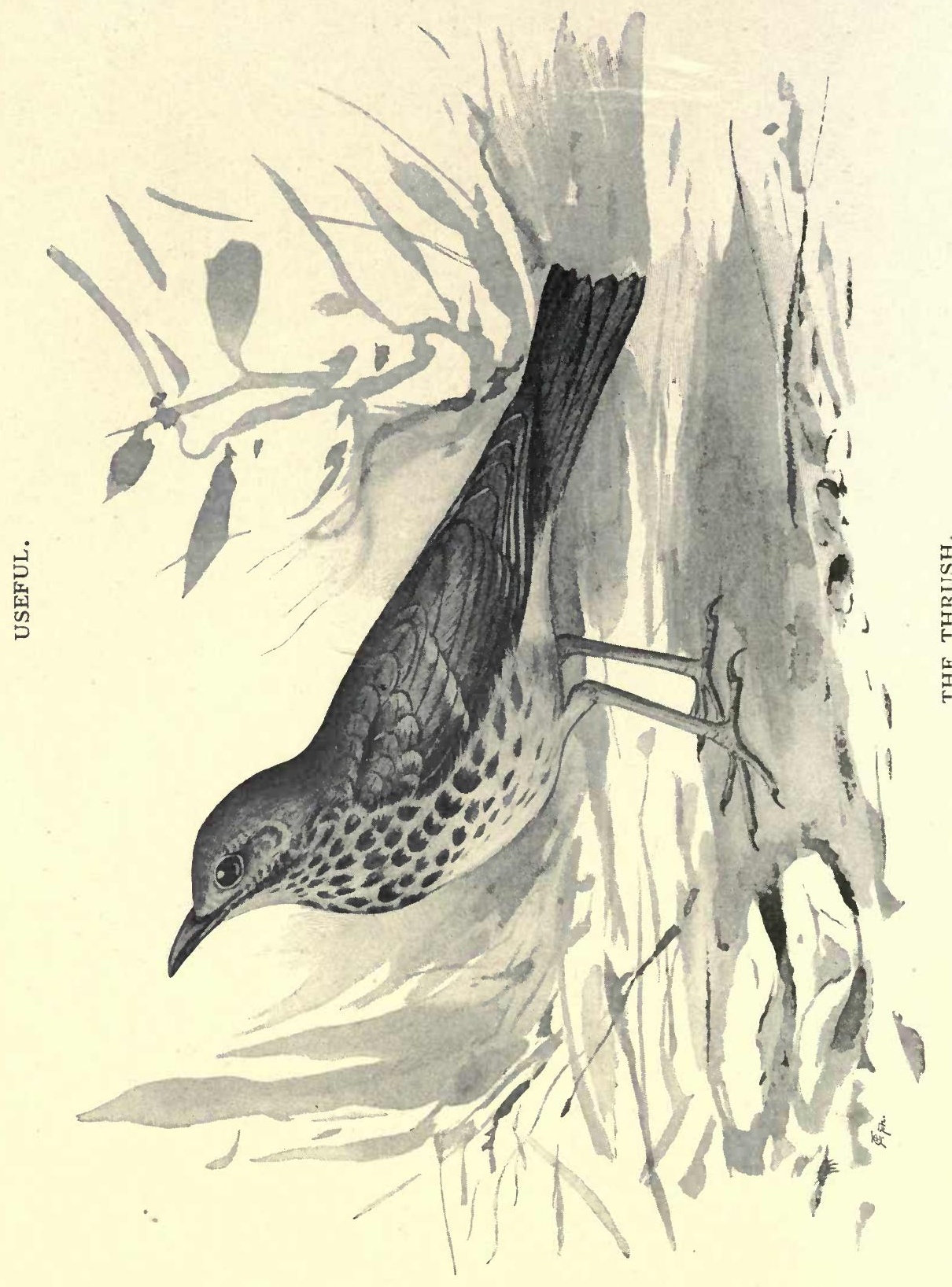


The Thrush.

(Turdus musicus.)

THIs bird is the same size as a Blackbird. The upper side is olive-brown; throat and under parts whitish; breast rusty-yellow with dark heart-shaped spots and flecks. A light eye-brow stripe runs over the eye. The under side of the wing is rusty-yellow; beak and legs brownish-yellow. Its nest is very remarkable. It builds by preference in trees with dense foliage, at a medium height, and employs stalks, grass, and small twigs well woven together, the crevices being filled with moss. There is nothing remarkable in this, for there are many better woven nests; but the cup of the nest is a work of art. It is wide, and deep, having inside a strong layer finely cemented and smoothed, about the thickness of the back of a table knife. This is composed of pulverised atoms of decayed wood, which the Thrush mixes with its sticky saliva, and kneads into a paste, with its beak. It lays five or six eggs of a vitriol-green colour, with very fine spots.

The Thrush is a fine strong bird, and moves firmly and skilfully among the branches. When on the ground it holds its head and beak well up; always alert. When it sees its prey it springs on it at once with lowered head, seizes it and tears it to pieces with its beak. On mossy grounds it is very skilful in turning over tufts of moss, in order to reach the insects which crawl about underneath. It also catches grasshoppers, and in the late summer and autumn attacks the wild berries.

It has many enemies. The Jay is the worst plunderer 
of its nest; but it has recently been ascertained that the Squirrel also sucks the eggs.

Its song is beautiful, flooding the woods far and near, with its rich fluty tones. It sings from the highest branches of trees, sitting quietly meanwhile, as if itself steeped in the dreamy rapture of its own performance.

The Song Thrush in Scotland is called the Mavis. This is strange as it is the Redwing which is known in France under the name of Mauvis. The song of the Blackbird is often confused with that of the Thrush; yet that of the latter is a very distinctive one, because in the middle of a strain of song there is the repetition of its three chief notes. You will seem to hear it saying "Pretty dear, pretty dear," or "Wait a bit, wait a bit.'

We must own that the Thrush is a very active thief, although it does feed much on insects, worms, and snails. It is absolutely necessary to protect one's fruit against this depredator.

Shakespeare speaks of the "throstle with his note so true," and Clare wrote

" And thrushes too 'gan clear their throats, And get by heart some two 'r three notes Of their intended summer song."

But Browning still more finely enters into the spirit of this bird's song :-

" That's the wise thrush; he sings each song twice over, Lest you should think he never can recapture The first, fine, careless rapture!"' 
The BlackBiRd.

(Turdus merula.)

THIS is a lively, cheery bird, an ornament to the thickets and clearings of the woods. Just before the evening twilight, in company with others of the Thrush family, it seeks the clearings and openings of the woods, and delights the eye of the beholder, by its hopping here and there, its darting and hunting-busily dragging worms out of the ground and attacking all the mischievous Chafer family. Then it flies on to the summit of a bush or an over-spreading bough, and its powerful, pure flutelike song resounds through the wood, and makes the listener forget all else. In autumn it eats the berries, sometimes fruit; but being very timid it is easily driven off. It is a useful bird and a pleasure to eye and ear.

This is the bird which is so often taken from the nest and reared. The male bird fetches a good price in Hungary, for it learns to whistle tunes-even from street-organs. Because it learns so easily, it sometimes happens, that in the middle of a beautiful tune which it has been taught, some most excruciating sound is heard, reminiscent of an ungreased cart-wheel. In Germany the Blackbird has become a town-bird; and people spread dried ant-eggs, chopped meat, and maggots, and make a nest for it near their vine-covered windows. It stays there also during the winter.

And what about the East? Why are children ever brought up in such a way that they seize a stone directly they see a Blackbird? 


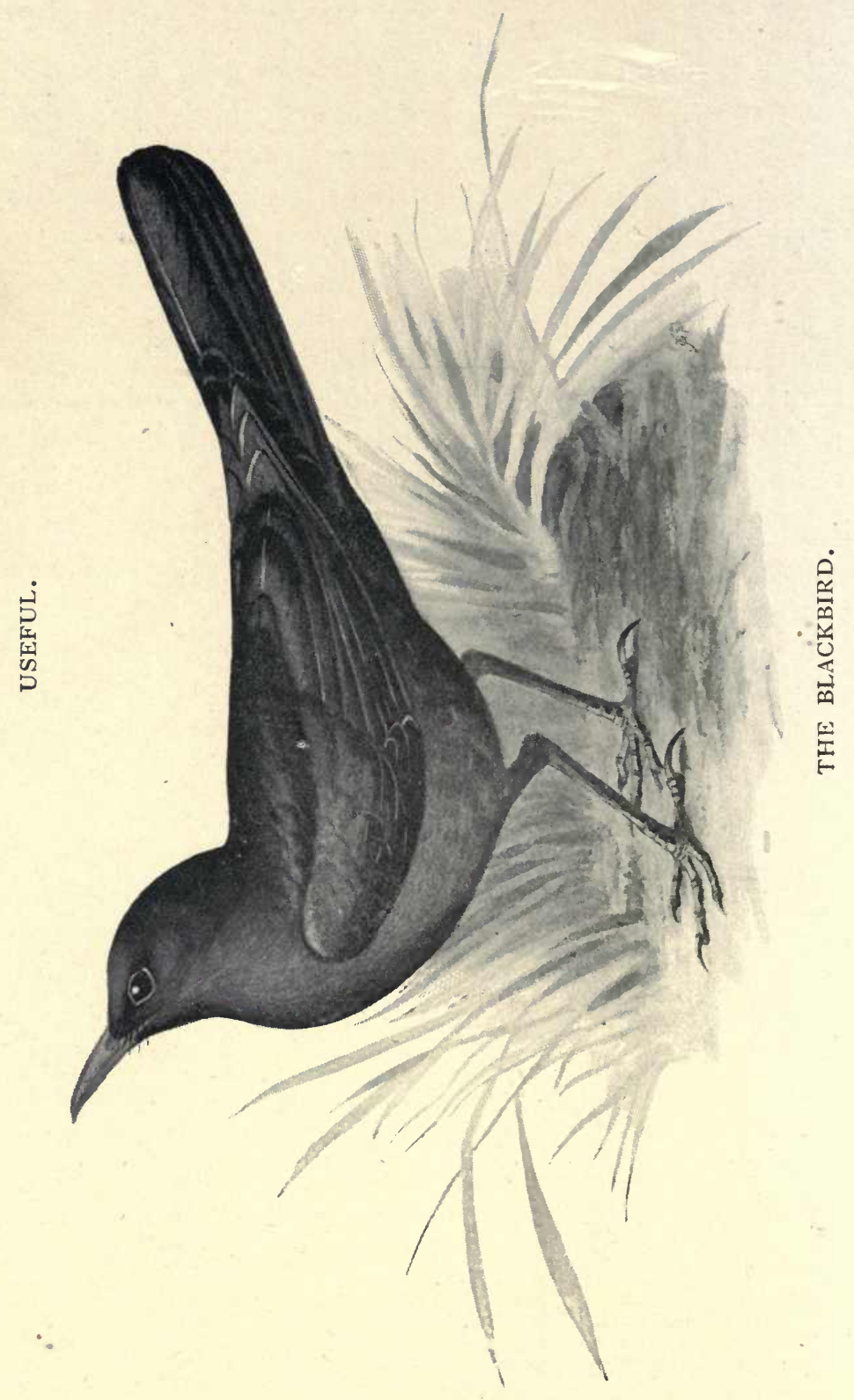


In February our English Blackbird will be thinking of mating. We are all familiar with the usual nestingsite which is chosen - evergreen, thick bushes, and hedgerows-but it has been known to build successfully and to lay its eggs, in the heart of what is known as the thousand-headed cabbage. The young of the early broods sometimes help the parents to feed the young of the second brood of the season.

The Blackbird is commoner in the South than the Thrush, and is as a rule more popular with the country people than the latter bird. Gardeners look upon it as a terrible thief, but the good it does in feeding on moths, beetles, other insects and larvæ, caterpillars, cockchafer grubs, quite counterbalances the harm it does in taking fruit. A well-known Zoologist says, "Short-sighted agriculturists kill the Blackbirds that, at the rate of sixty an hour, destroy their worst foes, or working as they do from early dawn to dusk six hundred in the course of a single day, which, given ten Blackbirds, raises the total of vermin put out of the way to six thousand per diem, against which a few dozens of strawberries should count as the dust in the balance. But the horticulturist sees the Blackbirds pick a raspberry now and again, and he does not see the same bird kill a dozen or two of grubs or snails for each morsel of fruit he may help himself to." Another, a Fruit-grower, says that during one hard winter when some of his fruit trees were killed, and in some places the Thrush tribe were all but annihilated, snails were a scourge in the following summer, and gooseberry bushes were stripped by caterpillars innumerable. This is the testimony of the late Joseph Witherspoon, a well-known fruit grower. He goes on to say, "When gardens are surrounded by 


\section{MISTLE THRUSH AND FIELDFARE}

woods, it is only by a liberal use of nets that any reasonable portion of fruit can be saved, as swarms of Blackbirds and Thrushes will eat every fruit as it ripens. I provide nesting-places, and thus have my birds so near my caterpillars, and so far from house morsels that they eat the pest greedily; but fruit crops being thereby secured, we must next draw on our ingenuity to prevent the birds taking more than their fair tithe."

In winter Blackbirds feed principally on snails, the shells of which they break by raising them in the bill and dashing them against a hard stone, just as Thrushes do. But for these birds, we should be quite unable to save our gardens from the wholesale ravages of those enemies to plant life.

The Blackbird, of course, belongs to the Thrush family, and its relatives the Fieldfare, the Redwing, and the Mistle Thrush all have the same habits of feeding. They all devour snails, slugs, worms, and insects, and in the autumn take wild berries. The Fieldfares are only with us in winter, and they seek their food over the fields and pasture lands in mild weather, and eat the berries when frost comes, and snow covers the ground. The Redwing is a delicate bird, and often comes to grief in our country during a hard winter. The Mistle Thrush is with us all the year, and its food consists, not of mistletoe as used to be supposed, but of the berries of the yew, holly, mountain ash, hawthorn, etc., worms, snails, and insects, and, it must be confessed, of a little fruit occasionallv.

The male bird is pure black, the eyes bordered with a fine golden yellow. The beak is also of this colour. Legs blackish. The female is dark-brown, chin whitish, 
breast a shabby brown with dark spots, beak and legs brown. The male does not attain his brilliant blackness until his third year. It builds its nest in bushes and thick foliage, where it is well hidden. It is composed chiefly of moss, fine twigs, and tufts of thair; and is strong and durable. The clutch consists of four to six eggs of pale green, speckled with pale rust-red and violet.

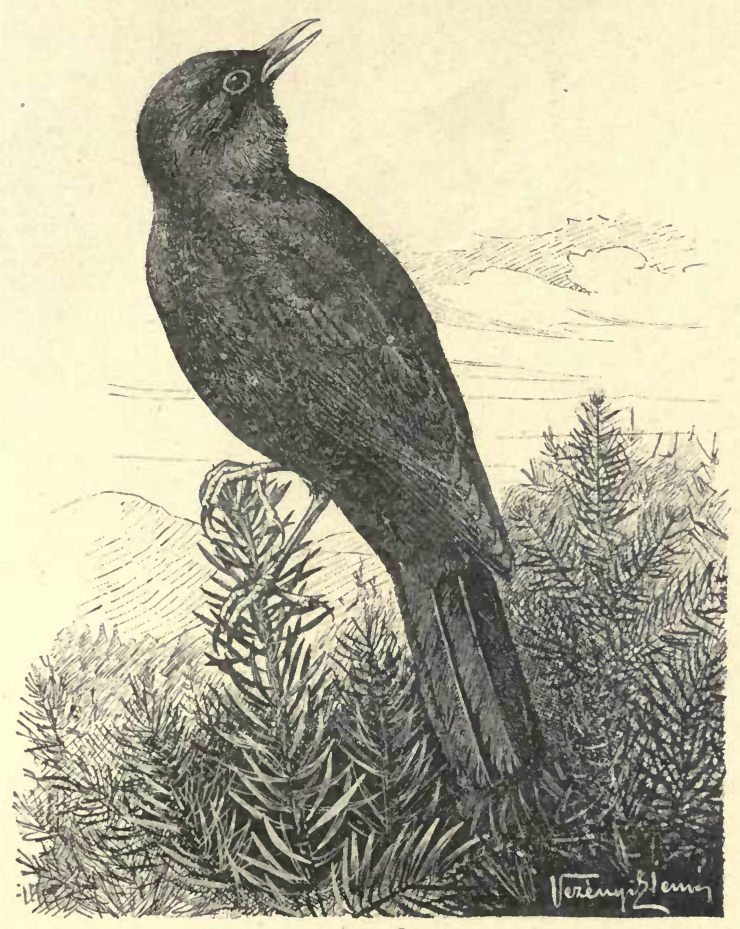

An evening lyric. 


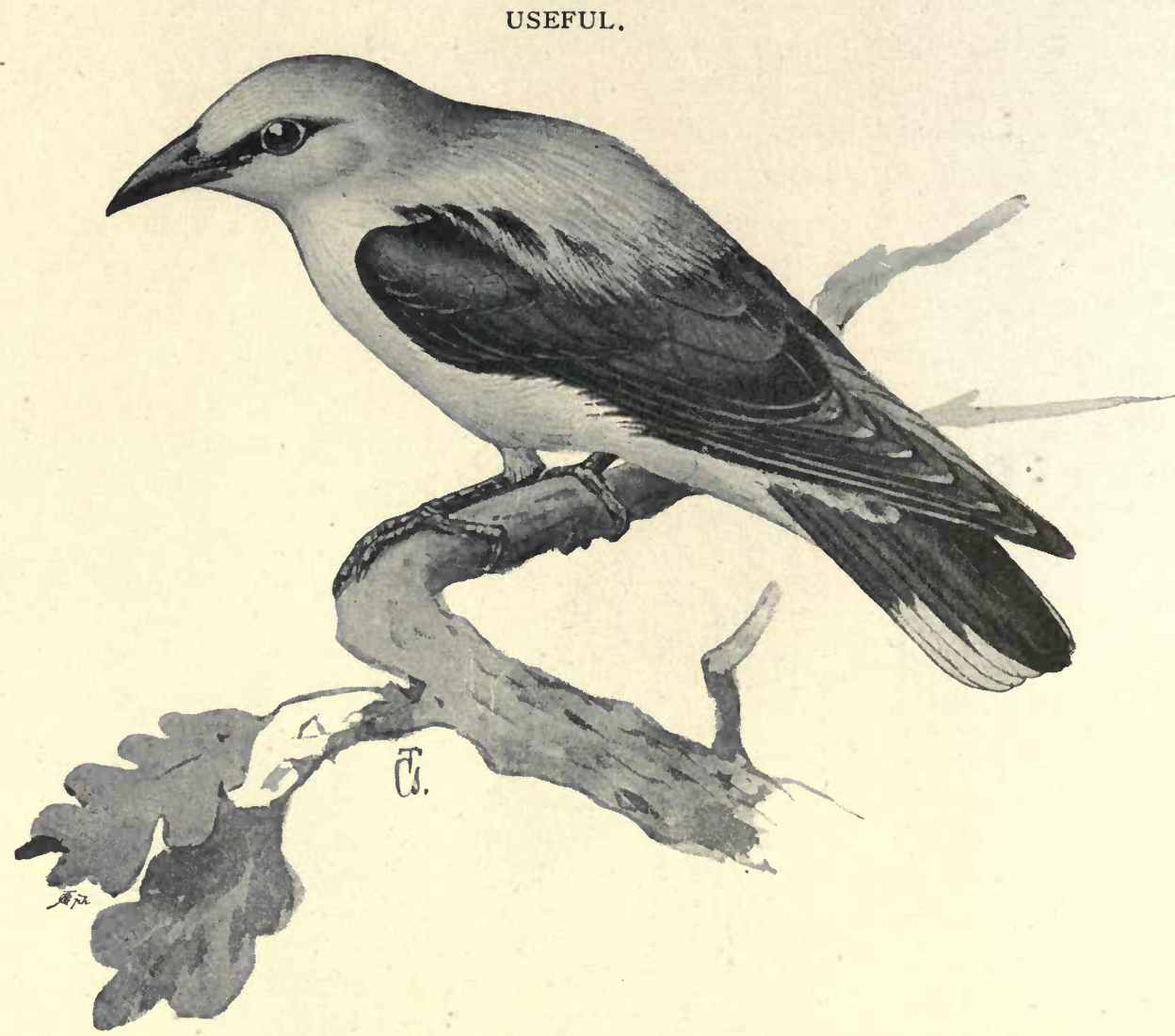

THE GOL.DEN ORIOLE. 


\section{THE ORIOLE.}

(Oriolus galbula.)

THIs bird is noisy in the spring and the early summer, its voice, which is full and deep like the note of the reedpipe, fills the edge of the woods and the great gardens. " Next to the call of the Cuckoo, the flute-like note of the Oriole most enlivens the early summer woods and so contributes to the perfect harmony of a sunny springtide-day; 'deelee-adid-leen,' or 'ditleo, deega, ditleeo' it sounds, always clear and joyonus out of the bushy treetops." In Hungary, it endeavours to lure away boys from too close proximity to the nest, by the cry, "kell-cy dió, fu??" which means "Boys do you want some nuts?",

Except at the fruit season, the Oriole is a very useful bird, and there is no kind of caterpillar that it will not pick up. In seasons when there are a great many cockchafers, it carries on a perfect war of extermination on these unhappy creatures. It is unfortunately true, however, that when the summer fruit is ripe-it departs for warmer regions before autumn-it troubles itself little about chafers, but turns its attention to cherries, apricots, morellas, and early pears. Still the good it does in destroying insects, is much greater than the harm it does otherwise, and therefore we will be indulgent to it. Besides, its lovely colour is a delight to the eye.

This Oriole comes annually to Cornwall and the Scilly Isles, but can only be called a visitor to our country, although nests have been found occasionally in some counties, especially in Kent. It is not unfrequently 
noticed in the Southern and Eastern counties of England.

Unfortunately collectors cannot resist adding this beautifully plumaged bird to their lists. I have watched it myself in Southern Germany and Hungary. It is not at all shy, and one of the most beautiful things in birdlife I have ever seen was a number of Orioles flitting from tree to tree in an orchard situated amongst vineyards on the hilly banks of the Danube in Baranya. The black on the wing-coverts and tail-feathers is in striking contrast with the golden-yellow of the greater part of the plumage. The male has a very flute-like call, hence its French name of Loriot. The female is a devoted mother. Where these birds have been protected on private estates in our country they have reared broods successfully; it would surely add to the beauty of our rural landscapes, if they were encouraged and protected.

The Oriole is rather larger than the Thrush. The male is a beautiful golden-yellow; wings and tail black except the end of the tail which is yellow. A black stripe passes across the eyes from the base of the beak; the beak is a reddish flesh colout, the eye blood-red. In the female and the young, all the parts which in the male are golden-yellow are greenish, the underparts a greyish-white with darker stripes. The nest is quite a work of art. It is always placed in the base of a fork of a branch, and is fastened to the bough with fine root fibre and bast; it is lined with any fine soft material, even cob-webs are sometimes found in it. The clutch usually consists of five eggs, which are white with a few very prominent dark specks. It also nests in gardens. 


\section{THE RoBin. \\ (Erithacus rubécula.)}

THE Robin is one of the cleverest courtiers. It alights on the ground, alternately appears and vanishes for a few moments, then suddenly stands still, makes a low bow, droops its wings, raises its tail, then looks up at one with shining eyes, full of confidence, as if to say : " I trust you." It hunts beetles with great energy, and does not even recoil before the slug, still less before a small earthworm, which the lordly hedge-sparrow would not touch for all the world.

Sometimes it flies on to a high branch, keeping quite still, except that now and then it makes a bow and raises its tail; then all at once it flies to the ground, pounces on the awaited booty, returns to its bough and devours its prey. Its song is beautiful, exquisite, rivalling, but not excelling, that of the Lark. The bird sits quietly and sings, and is in no hurry to cease. Its cry is a light piercing "see."

It is a bird which may be said to become tame almost immediately when caught. It likes to move at liberty about a room. Poor people with us like to keep it, for it catches the flies in the room, the spiders in the corners or even on the bed; or any other moving thing. This bonny bird deserves every protection.

The ways of the "cheery little Ruddock," as Shakespeare calls him, are so well known that it is not necessary 
USEFUL.

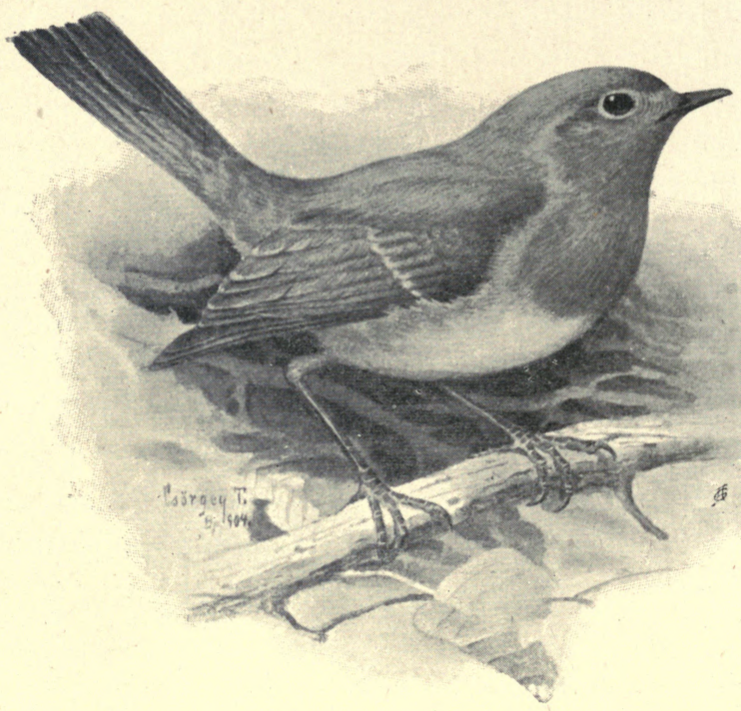

THE ROBIN. 
to add much more to Mr. Herman's graphic description. Perhaps it is not known to all our readers, however, that a great number of Robins migrate to our country every autumn from the Continent, whilst some of our homebred birds leave our shores. As a rule the red on the breast of the former is brighter than with those bred here. There are, however, as we know, individual birds which will attach themselves to a home where they have been treated kindly, for a number of successive winters, entering the open window and feeding with the children.

The Robin has three different styles of song, one the gay, joyous outpouring which delights us on sunny days, then the autumnal dirge, which proclaims the approach of cold stormy days, and is often uttered just before it leaves us for warmer quarters; and again, the long drawn-out cries, notes of distress, when some prowling cat or other enemy approaches its nest.

Robins, as we all know, devour great quantities of worms and insects. It is a most valuable species to the gardener and fruit grower, for, except under the stress of thirst, it lives only on animal food.

The Robin needs little description. The whole of the upper side, including the back of the head and crown, is olive brown, the under-parts dingy white; throat, breast, and brow a beautiful rose-red with us,--in some districts more chestnut-red,- - whence the bird is called the Redbreast. There are plainly discernable oblique stripes of a lighter shade on the wings. Eyes dark brown and large; legs dark and strong; beak finely pointed; plumage fine, soft, and loose. The nest is always placed low down, in the thickest bushes, in 
hollow trees, holes, and crevices. It is well and delicately built; the outer covering consists of dry leaves, the inner of thickly woven moss, rootlets, hair, and feathers. It is difficult to find. The eggs usually number five, occasionally seven; they are of a yellowish olive-brown speckled with rust colour, the speckling being closer in a ring round the thicker end. Two or even three broods are produced in the year.

"The Robin and the Wren

Are God Almighty's cock and hen.

Him that harries their nest,

Never shall his soul have rest."

Grahame sang-

“ Dearer the redbreast's note, That mourns the fading year in Scotia's vales, Than Philomel's where spring is ever new; More dear the redbreast's sober suit, So like the withered leaflet, than the glare Of gaudy wings that make the Iris dim." 


\section{THE WREN. \\ (Troglodytes pároulus.)}

The Wren is certainly the most lively of little birds. With its confiding nature, especially in winter, it approaches close to men, and with lightning speed dashes into the openings and gaps in the wood stack. It is visible only for a moment at a time, and, with its little upright tail, its nodding and see-sawing, its appearing and disappearing, its popping in and out, it disposes even the most morose persons to cheerfulness. It slips through the prickliest bunch of blackthorn like the nimblest mouse, and has scarcely vanished on one side, before it appears on the other, shoots about like an arrow and is quickly lost in the neighbouring hedge. It does not fly far. If it finds itself in difficulties in the open, it slips into a mouse-hole. It feeds on the tiniest, and most hidden insects. It finds the smallest spiders, caterpillars, chrysalises, and grubs, which it wants, with skill and inexhaustible energy. It is found both in summer and winter with us.

This little bird has also its song, which is louder than might be expected, suggesting somewhat that of the Canary. A listener to whom it is not known, is astonished if he happens to discover the tiny vocalist. It sings always in an open place. Its cry is " $Z r r$ 's Zezerr."'

A Lancashire naturalist writes of "the irrepressible vitality of the Wrens which prompts them to fling a song in the face of winter whenever they get a chance." A chiding, chattering song it is; flung out also in advance of the intruding footsteps that disturb the 
USEFUL.

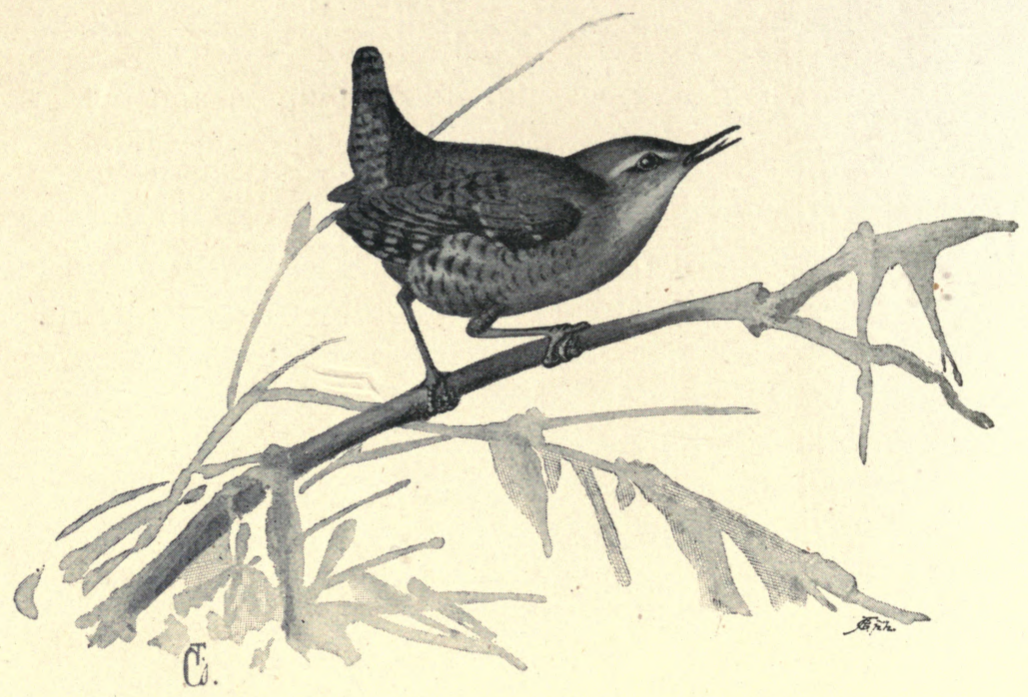

THE WREN. 
privacy of the hedge-row at the foot of which the bold, pert little creatures are seeking their food. In old nests in the thatch and holes in the walls, they find warmth and shelter during the winter, a little batch of them together. They are supposed to build special nests, " cocks' nests," they are called. A Staffordshire acquaintance tells how, being curious as to the number sleeping in one of these which he had previously noted in a grotto in his grounds, he and gardener surprised them one night by the light of a lanthorn, and no fewer than six Wrens fluttered out of the nest.

Another friend who was fishing near Brambridge, in Hampshire, tells me that he knows one such nest under the thatch of an under-keeper's cottage, and he has seen five or six enter this in the early twilight of a winter evening. On two different occasions, when a dogcart sent to the keeper's cottage at which he puts up, was waiting for him to drive to his day's fishing, a Wren settled on the back of the standing horse, near the cottage door, and remained there for a few minutes, as though enjoying the warmth coming through the creature's coat.

In Ireland every Wren that can be seen is hunted down and killed on St. Stephen's Day; and a Surrey man tells me that up to twenty-five years ago he has witnessed the same persecution in the home counties. Tradition says that it is due in Ireland to the fact of a party of Wrens hopping over a drum's head, and thereby disturbing a sentinel, when a party of Irish were on the point of surprising their enemies.

Shakespeare writes of " the Wren with little quill," in Bottom's song of birds ; and again, in " Cymbeline," Imogen says, " if there be yet left in Heaven as small a drop of pity as a Wren's eye." The comparisons 
drawn by old-fashioned country folk are often very quaint. I remember an old lady who, if she were asked to take more of some dish at table, often said, "Just a bit the size of a bee's knee," to the great edification of us youngsters. The song of the Wren is always the same : a few separate notes, a trill, a rattle and a trill, while its call-note has been likened to the clicking of a watch while it is being wound up. There is no more winsome picture of bird-life than this tiny creature dotting about, with little tail erect and fan-like, in quest of its insect food among the dry bramble leaves, so vivacious in its movements that no camera could ever do it justice.

The Wren is almost the smallest of European birds. There is not much to be said about the colouring of its feathers, which are the brown of the tree trunks, with beautiful thick oblique stripes of a darker shade. The colour is lighter over the eyes, on throat and breast. The tail feathers are especially fine, and thickly striped. The beak is slightly depressed, fine and sharp as a needle; the brown legs relatively strong. The nest is placed under the cover of felled boughs, between roots, in secluded corners of abandoned huts, which it can slip into. The nest is comparatively large, with a spacious entrance, and consists of a foundation of leaves and fine twigs, within which is a layer of moss, and again within that a mass of smooth, finely broken feathers. The clutch is six, sometimes, but rarely, eight small 'white ?ggs, with fine blood-red speckles. 


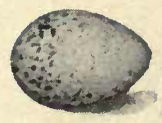

1.

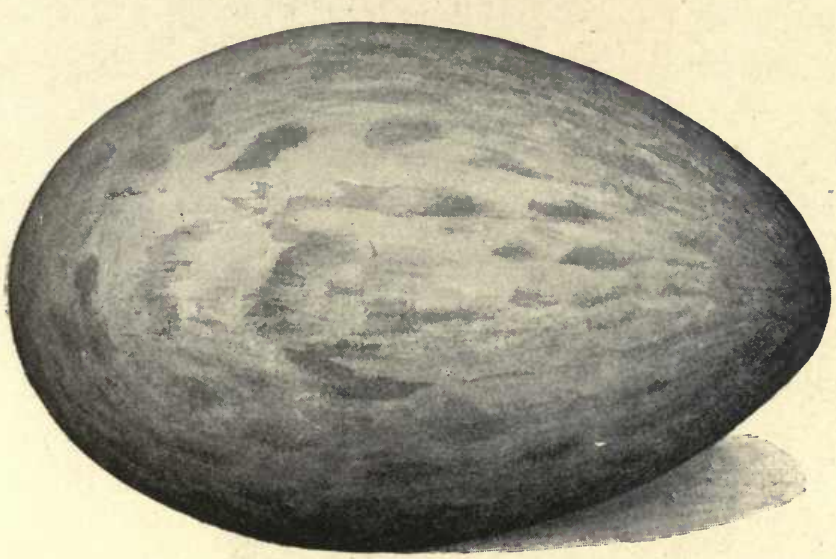

2.

1. Wren's Egg.

2. Great Bustard's Egg.

Comparative sizes. 
DOUBTFUL.

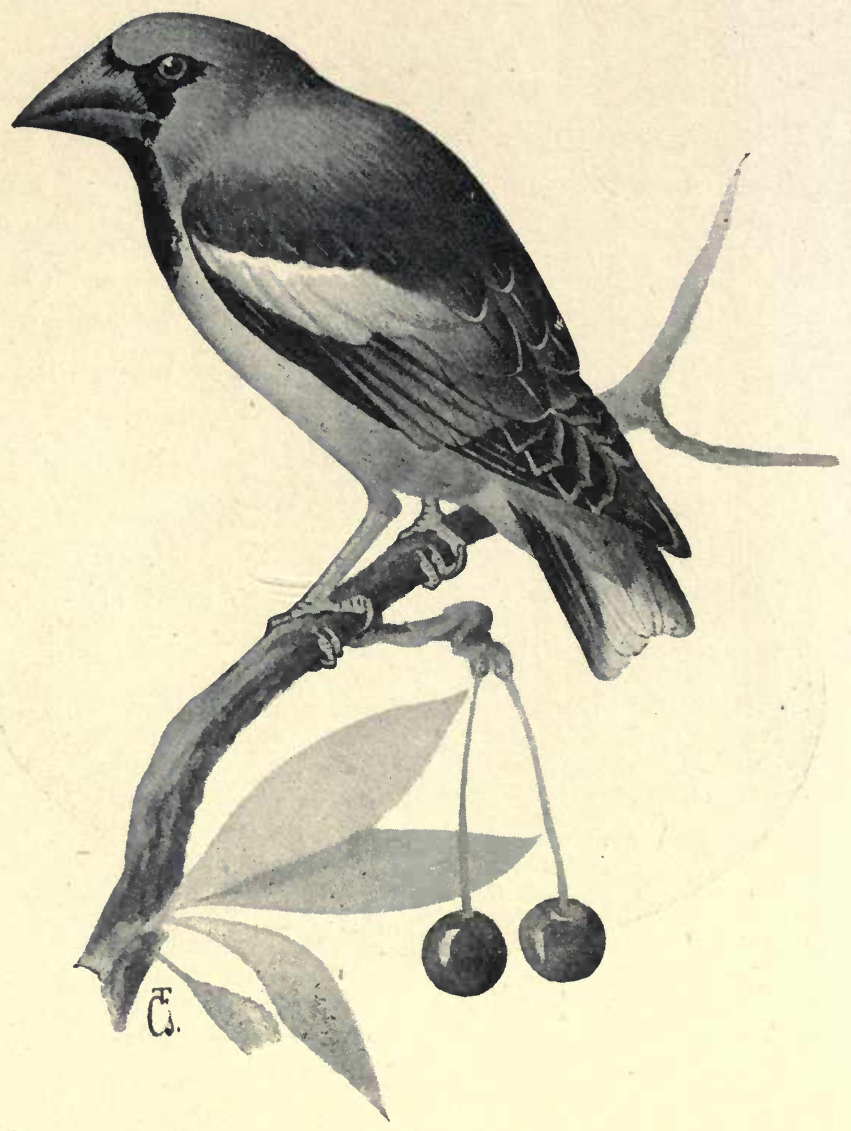

THE HAWFINCH. 


\section{The Hawfinch. (Coccothraustes vulgaris.)}

THIs is not a true migrant, for it is only in severe winters that it seeks a warmer climate. In autumn it comes from the hills, down into the plain, to the neighbourhood of human habitations, where it leads a restless life. It is timid, and easily startled; while flying it utters its shrill cry "seu, seu, seu." The striking bulk of its beak indicates the strength it has to use in obtaining its food; and it is so, for the kernels of the hardest cherry stones are its favourite dainty.

It flies in small flocks, and when these light on a cherry tree, they are quite quiet, not a sound is heard, except the cracking of the hard shells by the strong bills, which are specially formed for the work. The cherry stone lies in the lower mandible, the upper one being ribbed and so perfectly adapted for cracking the stone. This bird breaks with ease a fruit stone, which a full-grown man can only crush with the heavy pressure of his boot heel. Towards spring, when there are no more fruit stones to be found, it attacks and destroys the young leaf buds.

This bird is not very commonly found in Hungary.

The number of Hawfinches has been steadily increasing in England of late years. This is probably due to Bird Protection, which is so much more enforced than it used to be. The young are fed chiefly on caterpillars, but unfortunately they soon take to eating peas, which brings them into bad repute with gardeners, and numbers of young birds are shot and buried in gardens 
where peas are grown. It is pleasant, on the other hand, to watch them amongst the wild plums and sloes and crab-trees in one of of our old hedgerows, but is not an easy matter as they are so suspicious. In districts where many peas are grown for the market, these birds are a perfect plague. In Germany this bird is called Kernbeisser (kernel biter) because of the ease with which it cracks cherry stones with its powerful bill. With us it eats the seeds of the horn-beam and other trees, beechmast, haws, etc.

Only one brood is raised in a season, but if the first nest is meddled with, another one is made.

In "Within an Hour of London Town" the writer interviews a gardener on the subject of Hawfinches. We give it here as it stands.

"What do I want with the gun? Hawfinches; they hawfinches in my peas!" he grunts.

As he leaves the tool-house I quietly follow, and place myself with him behind a low faggot-stack which stands in a line with the peas.

" Jest hear 'em! ain't it cruel !" he whispers. " I hope the whole roost of 'em may git in a lump so that I ken blow 'em to rags an' tatters. If you didn't know what it was you'd think some old cow was grindin' up them peas. Ain't they scrunchin' of 'em! All right now, I ken see you, you grindin' varmints! Now for it!" Bang!

Three birds fall-young ones in their first plumage, which has a strong likeness to that of a greenfinch.

After picking the birds up, we examine the pea-rows. There is no doubt as to the mischief the birds have done. The old fellow's own expression, " grinding up," is the 
best to convey any idea of the destruction that has taken place. Where the birds have been, nothing remains but the stringy portion of the pods of his precious " Marrer fats."

There is enormous power in the bill of the Hawfinch, when the size of the bird is considered. The pea-pod is simply run through the bill, and the contents are squeezed out in a state of green pulp and swallowed.

“ Varmints I call 'em, an' nothin' else," is the remark my old friend makes, as he goes towards the tool-house and takes from a shelf a hen Hawfinch and two young ones, the former probably the mother of some of the birds that are about, if not, indeed, of the whole brood, her plumage showing that she has been sitting.

"People wants me to git 'em full-feathered old birds for stuffin', but bless ye, ye might as well try to ketch weasels asleep. A cock Hawfinch is about one o' the most artful customers as I knows on. The only time to get a clip at 'em is in winter, under the plum and damson trees. They gits there after the stones, any amount o' stones lays jest under the ground, an' they picks 'em out an' cracks them easy. I gits plenty o' young ones when peas are about - the old ones lets 'em come, but they take precious good care they don't come off the tops o' the trees themselves afore they knows there ain't nobody about. Some says they're scarce birds. I knows they ain't-leastways not when my peas are ready to gather."

The Hawfinch is seven inches in length and has a thick head, short tail, and very strong bill. Crown and cheeks cinnamon brown, neck greyish, mantle chestnut. There is a black patch on the throat, the base of the bill, and the eye, and a white patch on the 
wing. The tail is white in the middle and darker at the sides, the underparts are greyish with a tinge of violet. The middle wing feathers are serrated in wavy curves, and look as if clipt with scissors, the bill is exceptionally strong, very thick at the base, and sharp at the point. It lays four to six eggs of a pale green colour slightly speckled. The nest is well-built and is placed in fruit trees, and in open spaces in the woods, at a height of from six feet upwards.

The moral of the story of the gardener and the Hawfinch is that the gardener must protect his peas. 


\section{The Chaffinch. \\ (Fringilla calebs.)}

THE Chaffinch is a useful bird, and is also an ornament to the woods and gardens, not only by its lovely plumage, its friendliness, and its movements, but especially by its clear voice which rings like a silver bell. Its call-note is "fink-fink," and it has a short, cheery little song. Through the whole laying and brooding season it is busy with the destructive grubs and insects, especially the little caterpillars and tiny beetles which destroy the buds on the trees. When the seeds are ripe it lives entirely on them, but almost exclusively on those which it is able to pick up from the ground. It is true that when a considerable number of these birds visit a vegetable garden they do a great deal of harm, but this is outweighed by the good they do.

In very severe winters, it comes either in flocks or small parties with other starving companions-YellowHammers, Siskins, Crested Larks, and Sparrows-into the villages, and even towns, and picks over the heaps of street refuse and gutter sweepings.

It is still common with us in Hungary.

This Chaffinch is one of our common British species in winter, although in some seasons their numbers are unaccountably smaller than in others. It was called colebs, or bachelor, because of a partial separation of the sexes which takes place during the winter. Large flocks arrive from the Continent at that season on our East coast, whilst others come from the North of our islands to spread themselves inland. Unfortunately the 
USEFUL.

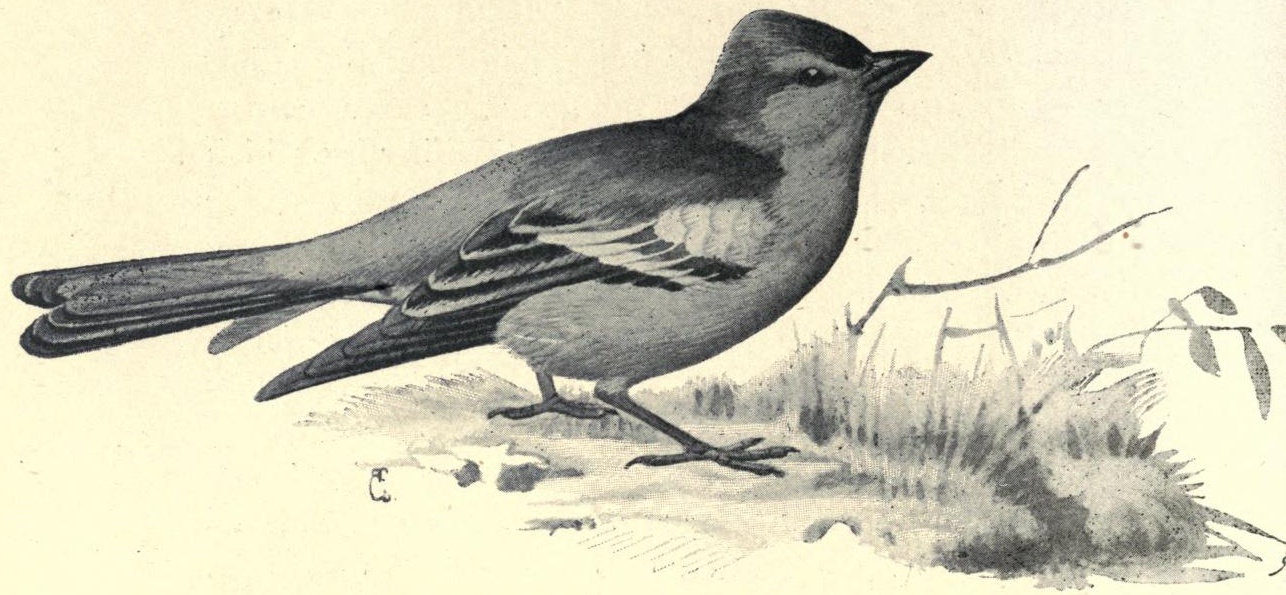

THE CHAFFINCH. 
Chaffinch is the favourite bird in the shops of the Seven Dials in London, and before the Bird Protection Acts came into force, many a country lane has been cleared of Chaffinches to the great disgust of many of the residents in the neighbourhood.

In Germany this is called the Buchfink-Beechfinchbecause of its fondness for beech woods. In the Thurigen Forest they have come to our table like Sparrows for crumbs. It frequents our suburban gardens.

The Chaffinch is a delightful bird in garden and wood. The full-grown male has a broad white stripe and a smaller yellow stripe on the wings; the two outer feathers of the tail arelarge, with white wedge-shaped spots, which give the bird in flight a very variegated appearance. Crown and neck are bluish-grey; brow black; cheeks. and under parts brownish-red; wings and tail black, except the white spots. The female and young are more plainly coloured; otherwise, like the male. Its nest is built among the high tree-tops, sometimes quite in the open, and is made of tufts of hair, moss, root-fibres, wool, and hair, very skilfully constructed. It lays five or six eggs with dark dots and fine markings, but occasionally of a uniform colour.

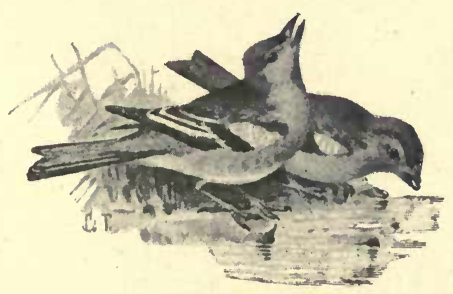

Chaffinches at the stream. 
MAINLY USEFUL.

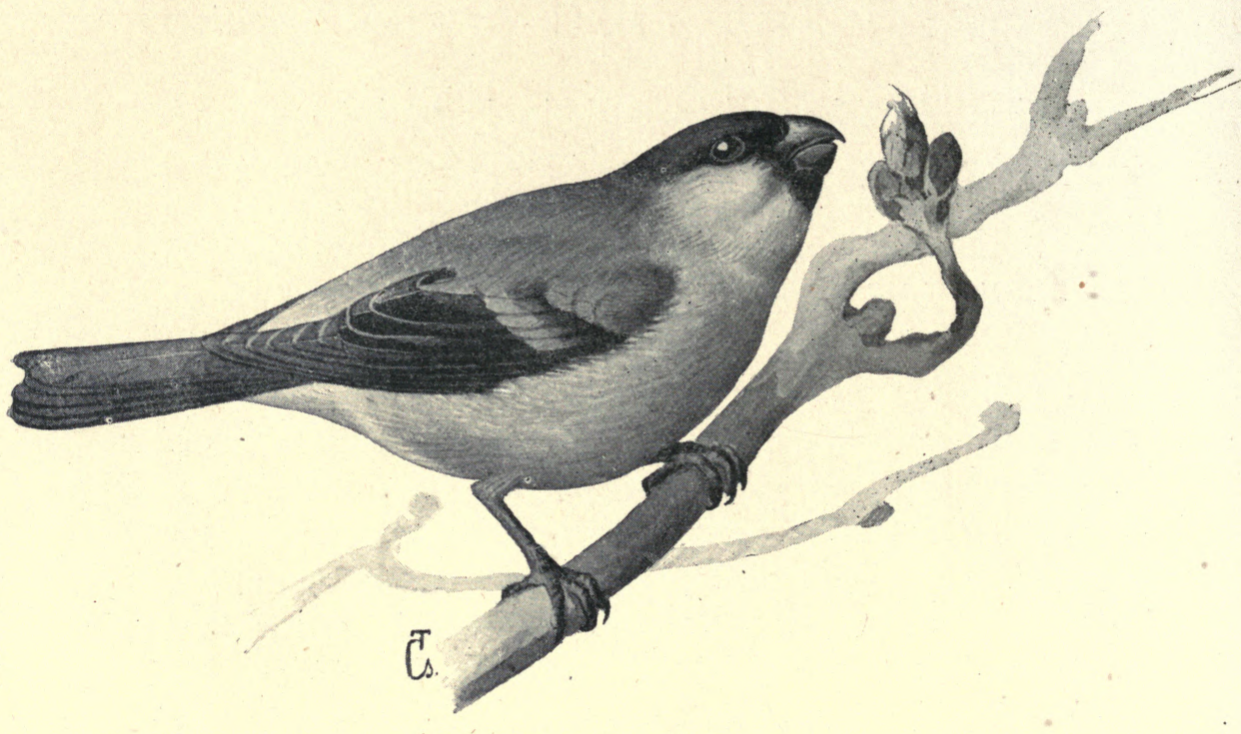

THE BULLFINCH. 


\section{The BullFinch.}

\section{(Pyrrhula europoea.)}

THE Bullfinch lives in summer in the mountains, and descends in late autumn to the plains, where it meets its far bigger relatives who come to us for the winter from the Far North, and joins company with them in wood and grove and garden, even in the immediate neighbourhood of dwellings. When the sunshine glisteris on frost and snow, and these splendidly coloured birds settle on a dry bough, the scene presents a lovely winter landscape the impression of which is heightened by its melancholy subdued cry, "deeu," or “beut, beut." In captivity it learns to sing tunes. It is easily caught, for it is incautious.

In winter it visits plants, choosing the young wild vines, buds, seeds of all kinds, berries including those of the alder, and the wayfaring tree; it does not attack weeds. In very severe winters, when starving, it will also do mischief among the buds of the fruit-trees.

It is frequently seen in winter.

The Bullfinch has been causing much dissension in and near an East Anglian district where I have lately been staying. A net had been placed over the gooseberry bushes to protect the blossom, and much indignation was caused early one morning by the sight of three lusty Bullfinches within the meshes, and a quantity of promising blossom on the ground. "There would be no gooseberries whatever, this season; it was positively unbearable; sentiment was utterly misplaced." The three birds were caught by the hand within the net, two 
were put in a cage in the stable, and one was exposed in a small cage on the top of the garden wall to attract others to the like fate. The gardeners were inexorable. Madame was irritated by the sight of the rifled twigs. "And all last Sunday was spent, by the wife and me," said the gardener, "shying stones at the rascals among the trees in our own garden." The next day a marketgardener shot no less than six Bullfinches on his grounds.

As a rule, my friends on this estate, are extremely good to birds, and they attract them by placing breeding boxes, and supplying food in winter; but these sturdy rascals find no quarter. I pleaded hard for them, but, I fear, without result. The gooseberry blossoms was certainly nearly all destroyed, but it was in a quest for the destructive larvæ of the winter moths, which make their appearance in the early spring and eat the not yet expanded buds. A fruit grower has stated that he allowed the Bullfinches to eat as much as they pleased; the crop of fruit has usually been as good as if the birds had not done any disbudding, and when, by a rare chance, the trees had borne no fruit at all, he knew it was because the trees required clearing, and the next year the crop would be all the finer. In some cases the tree appears to be entirely disbudded, and still fruit has appeared.

It is only for a short period that the Bullfinches visit the fruit trees. During the rest of the year they eat the seeds of harmful weeds-dock, thistle, groundsel, plantain; and one authority states that a single Bullfinch has been known to devour 238 seeds of the common speàr-thistle in twenty minutes! $\mathrm{A}$ writer in the Journal of the Royal Agricultural Society say that he 
has seen "a small party of these birds eagerly devouring the seeds of the large sow-thistle." A little fruit more or less in a season, in one's own domain, is a small matter in comparison with the vast amount of noxious weeds destroyed on our fields.

The Bullfinch is an ornament in a garden. Crown, wings, and tail are shining black, and the same colour surrounds the bill; mantle a beautiful ashen-grey, rump and under tail cover snow white, breast and under-parts a fine red. In the female the under-part is ashen-grey. Bill short but very thick, at the end curved and hooked. The clutch is composed of five green eggs with purple and grey speckles. It nests in the fir woods of the mountains, at a height of about six yards; the nest is made of thin twigs and is lined with hair.

The Goldfinch (Carduélis élegans) is so well known in Great Britain that it requires little description. Unhappily for the "Proud Tailor," as he is called in the Midlands, he has always been a favourite cage-bird, and on the South Downs Goldfinches have been captured in thousands at the times of migration, to be miserably caged in dozens for the bird dealers.

They are birds which found their food on the waste lands where large thistles used to grow, and with the improvement of these waste lands the thistles have gone, and the Goldfinches with them. Increased Bird Protection is, however, causing more. Goldfinches to breed amongst us, which is a good thing for agriculture, this bird's food consisting, as it does, of the seeds of the thistle, knap-weed, groundsel, dock, and other plants. The Goldfinch is considered to be one of the most useful 
of all our birds, feeding, as it does, on the seeds of noxious plants of which there is a succession all the year round. It ought to be encouraged in orchards, where it feeds its young on small caterpillars, and destroys great numbers of other insects for them.

Its relative, the Greenfinch (Ligurinus chlóris), a common and well-known species everywhere, is not quite so valuable a bird to the agriculturist as the above species. It is well known that it steals much swede and turnip seed, still it devours quantities of the seeds of such weeds as dandelion, corn marigold, charlock, wild vetch, etc., and the parents capture immense quantities of moths, flies, caterpillars, and other pests for their young.

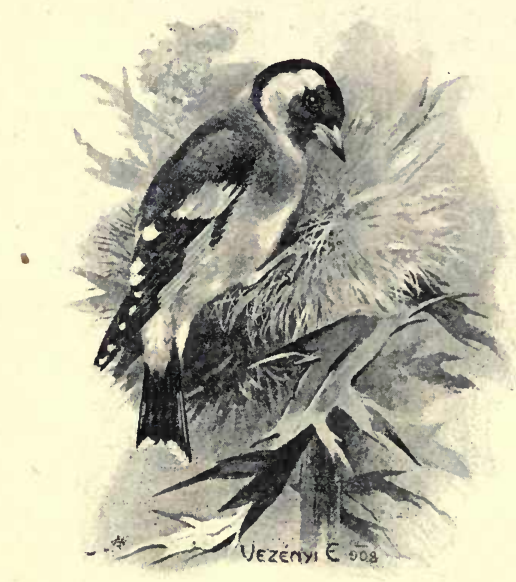

A Feast of Thistle Seed. 
The Yellow Hammer.

(Emberiza citrinella.)

THIS is a pretty, cheerful, friendly bird, that lives in gardens, thickets, or the outer part of the woods. Its chief distinguishing characteristic is that it loves to associate with other kinds of birds, especially the Fieldfares, with which it is most intimate. During the brooding time and before the seeds are ripe it lives chiefly on grubs and insects, being particularly fond of the smooth caterpillars, which the other birds do not much relish. It also likes seeds, and rather the floury than the oily ones. In winter it flies about the fields with other birds, and destroys the seed of the runners, and the weeds that shoot up through the snow-and is thus doubly of use to the farmer.

In a severe winter it comes with other feathered visitors into the inhabited districts. At the weekly market it appears with Finches, Crested Larks, and Sparrows, and picks up the oats and other grain which are lying about, showing little timidity in doing so. It has a dipping flight. It enlivens the country-side in spring and summer with its song.

It is very numerous with us in Hungary.

This bird is resident and common in most parts of Great Britain. From morning till evening it sings the same song all through the spring and summer; it has been transcribed as "Little bit of bread and no che-eese." The form and hardness of its bill, proclaims the bird to be a grain eater, and of course it will pick up a great deal of corn, where it is to be found, yet both 


\section{USEFUL.}

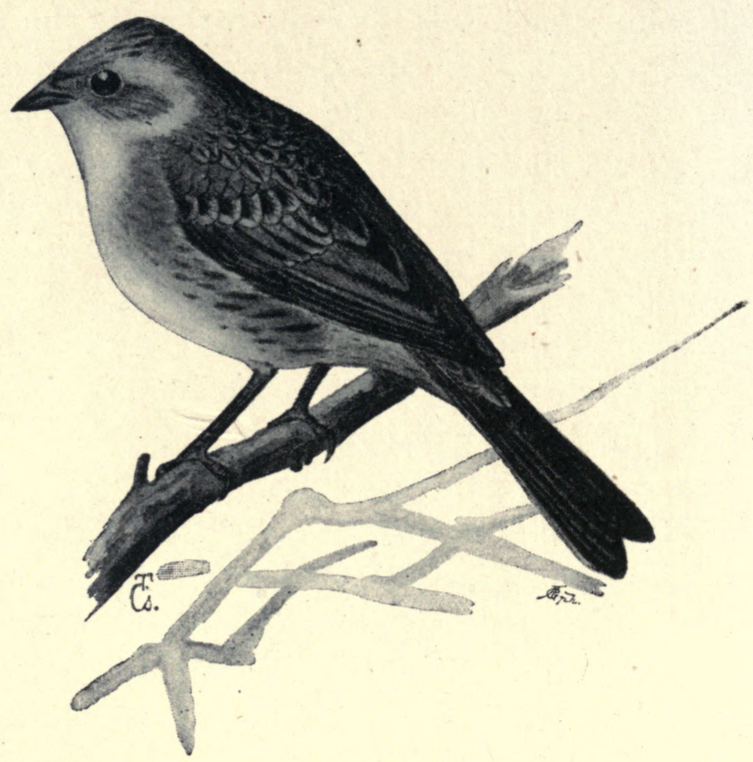

YELLOW HAMMER OR BUNTING. 
old and young birds live upon insects largely, as well as the seeds of baneful weeds, and it has been estimated with us that the good it does far outweighs any harm which the farmer suffers through it.

The Yellow Bunting, well known under its universal name of Yellow Hammer, says "A Son of the Marshes," " is a very handsome bird and a very common one. The plumage is splashed with rich yellows, warm red-browns and darker streaks; this is his nesting suit. In winter the colouring is not quite so gay. Where farms or farm-buildings show, you will be sure to find Yellow Hammers round about them. Stand just inside the stable, after the horses have left it in the morning for their work in the fields, and look at the birds gathered round the open door, all busily picking up the grains of oats that have fallen from the nose-bags. A fine midApril morning suits the bird to perfection, for he droops his wings, spreads his tail out, and glides here and there pecking up as he goes, in the most dainty manner. Then, for a time, he visits the trees.

The lowering of the wings, until they almost touch the ground, and the spreading out of the tail, is a peculiar trait seen more or less in the whole of the Bunting family.

Trees and fields are necessary to the well-being of the Yellow-Hammer, which may be considered one of the farmer's friends; for at certain seasons he, as well as others of his family, live in the fields, only leaving them to rest, or roost in the trees that surround them. Innocent as the creature is in all its ways and means of living, superstitition has linked its name with evil. I have been assured, in the most solemn manner, that the 
badger, the toad, and the Yellow Hammer are all in league with the Prince of Darkness."

The Cirl Bunting, often called the French Yellow Hammer, which is distinguished from the commoner bird by the dark throat gorget, is more numerous at times than it is supposed to be. In fact it is becoming fairly common as a resident species.

The Yellow Hammer is the size of a Sparrow but longer and more elegant. Throat, underparts, and crown of the full-grown male, golden-yellow; mantle rust-red merging into green. The bill is peculiar, the lower half is compressed, and the upper half is so formed that it is adapted for shelling seeds. Its well built nest is placed low down among the bushes. It lays five eggs which have dark markings on a light ground.

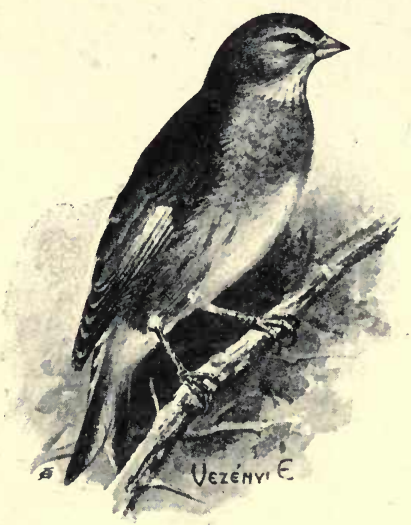


The Turtle Dove.

(Turtur communis.)

The Turtle Dove has a pretty, dainty walk, an uncommonly rapid flight, and is altogether a beautiful pleasant cleanly bird. The pairs are devoted to each other.. Their cooing, "turr, turr," is pleasing, gentle, and rich. It is a harmonious sound which makes a soothing impression on the mind. It is no wonder that, from its whole nature, the Turtle Dove has been chosen as the symbol of faithful love. Popular sentiment is shown in the widespread belief, that if his mate is taken from him, the male bird dies of grief-or that in sorrow for his loss he never again sits on a green bough. The Turtle Dove loves the border of a wood, or the trees, and rows of poplars that skirt a corn-field. It likes to be near clear water to which the birds come in flocks to drink. Its food consists almost entirely of seeds, chiefly those of weeds. That is why this bird is so useful to the farmer. It does, indeed, sometimes take toll of the grains, in the corn-field, when they have not been properly covered by the harrow. Then, indeed, the Doves so fill their crops, that bare places do not fail to appear on the ground. But this bad behaviour lasts only for a short time; besides it is not very bad, for they eat chiefly the superfluous grains. It is quite different with regard to the seeds of weeds, which they destroy the whole summer through in great quantities. A student of bird-lore once opened the crop of a Dove in midsummer, and found in it 1942 seeds, of which all but one were the seeds of the poisonous willow-leaved wolfsmilk-the one exception being also the seed of a noxious 


\section{USEFLL.}

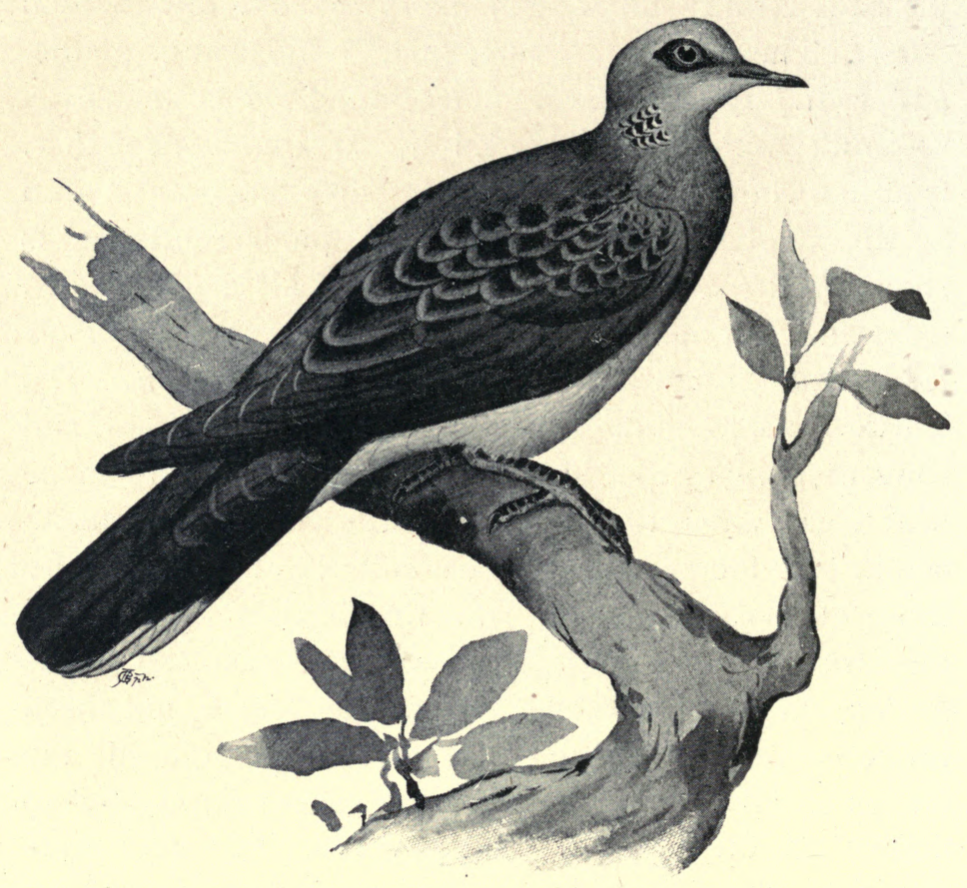

THE TURTLE DOVE. 
weed. There can be no doubt that this bird does more good than harm-and we will, therefore, encourage and protect it.

It is still common in Hungary.

It is common in some parts of England, but is very local in its visitations and is only a summer visitor. A " Son of the Marshes," says, "It is common enough in some parts of Surrey. I have seen from ten to thirty of them rise from the standing oats, or from the long grass in the hayfield, at one flight. One of my friends shot a couple as they were rising from the oats, and opened their crops. Not a single grain of oat did he find in them. They were full of a little vetch that grew abundantly at the roots of the oats, or, to express it in true rustic agricultural phrase, ' at the stam o' the whuts.' I was with the man at the time; after that examination of the birds' crops he declared he would never shoot another pigeon."

Another member of this family, the beautiful Ring Dove or Wood Pigeon (Colimba palumbus), called Queest in Ireland, and Cushat in the North, because of its soft notes, is a bird that we could ill-spare from our woods and coppices. It is, however, an undeniable fact that the members of this voracious species have increased of late years in a manner which is alarming to the hard-working farmer. Many writers have taken up the cudgels in defence of these birds on account mainly of the amount of noxious weeds, wild mustard seed, and leaves they devour, but, as that great naturalist, the late Lord Lilford, wrote, in sending me a little box of the contents of the crops of three birds extracted by himself : "In a highly-farmed country 
these weeds hardly exist; and," he added, " in my opinion his good deeds are in no way comparable to the damage done. I have frequently, when shooting Wood Pigeons in the winter months, seen their crops burst on coming down dead from a height, from distension with hearts, acorns, barley, and turnip-tops.'” The contents of the three birds' crops sent to me were I 29 peas, 85 beans, and some broken vegetable matter.

The amount of good or of harm done by this species varies, as in the case of other birds, according to the weather and the scarcity or plenty of their natural food about the woods and the lands skirting these. Considering the numbers that breed in our midst the farmers might well thin these, and send a better supply of birds to the market.

The Turtle Dove is smaller than the Pigeon, slenderer, and it has a more stately form. Crown and brow are a beautiful grey, cheeks and ear parts flushed with rust colour. On each side of the neck it has an ornament of black and white dots arranged in rows. The mantle is ashen-grey with dark specks which have a reddish border. The rump is ashen-grey with a shade of rust colour. Throat and breast reddish, melting into violet; the under-parts are white. The wings are black, shaded with slate colour; tail slate colour; four, at least, of the tail feathers have white tips. Beak black, the irides fiery red; legs blood-red. The young birds are of soberer colour. The nest is placed in thickets and is well hidden. It is composed of little branches and twigs, very lightly put together-indeed so loose and open is it, that the eggs and the sitting hen can be seen through it. It lays two white eggs. 


\section{CHAPTER VII.}

\section{SOME WILDFOWL.}

The Lapwing.

\section{(Vanéllus vulgáris.)}

THE reedlands and meadow-lands, moist fields, marsh and lake districts, would be desolate and lifeless without the beautiful Lapwings. They wheel and flap, and twist, and wheel again, on the large open uplands, so that their varied plumage almost dazzles the eye, and when several pairs frequent the same field they embellish air and sky. When the nesting time arrives the whole neighbourhood resounds with the call which the bird utters while in flight. The call-note sounds like " Keevit," from which, of course, its name is taken. The pairing note sounds like "Ka kerkhoit, kewit, kewit, kewit, kewit." It can run well and quickly on the ground. If a dog or a crow approaches the nest it flies at it with a loud, despairing cry, "Chrait," and strikes at the enemy with its beak; if a man shows himself it practices all kinds of cunning tricks. It flies along near the ground, repeatedly stopping, and so lures him away from the nest. The eggs of the Lapwing are much sought after. Its usual food consists of worms, the various kinds of snails, chafers, grasshoppers. In autumn it covers the fields and meadows in great flocks like a cloud, and destroys the pests of agriculture. It departs in winter. It is recommended for protection both on account of its beauty and its usefulness. 


\section{USEFUL.}

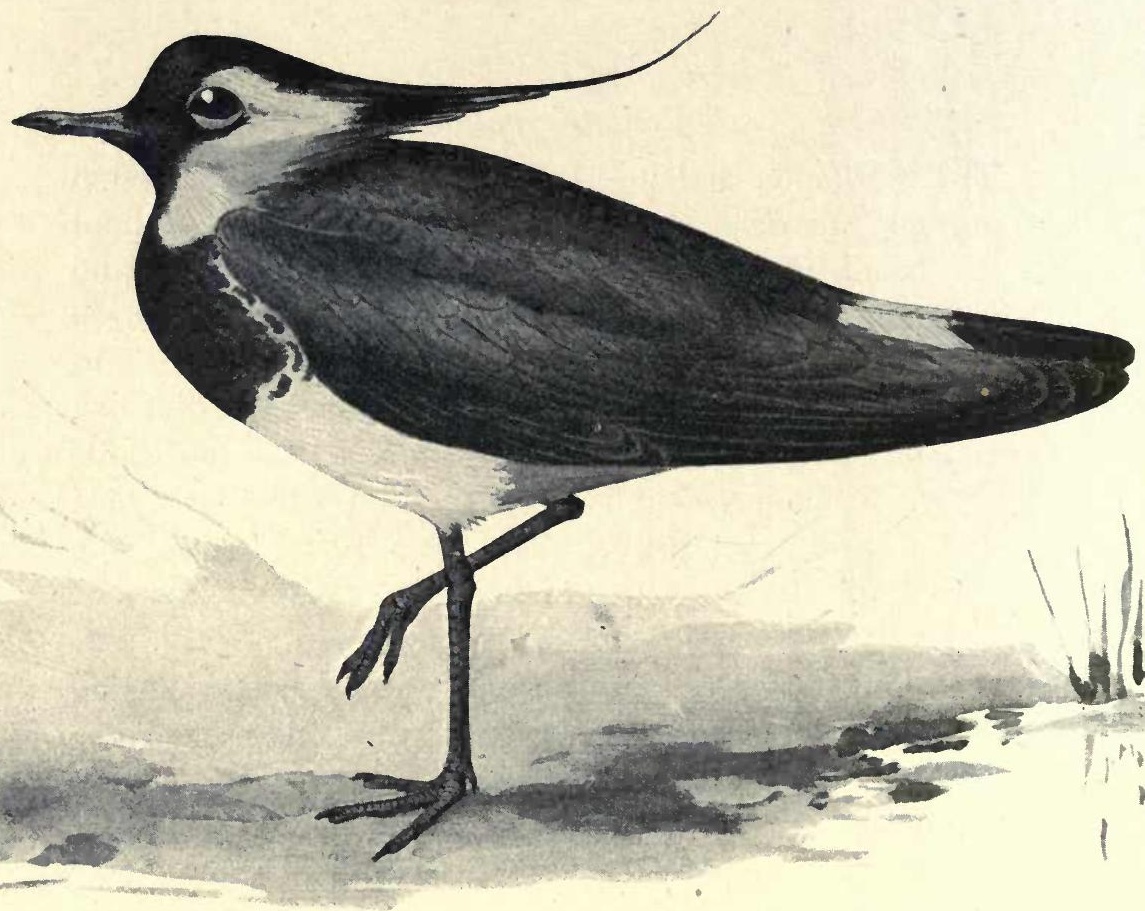

THE LAPWING. 
Sir Herbert Maxwell, writing last autumn, 1908, in the Pall Mall Gasette, after referring to another species, says: "There is another bird equally industrious in ridding the farm of insect pests and with no fruit or grain eating propensities whatever, which we allow each year to be slain in increasing numbers. Already in poulterers' shops, not of the first class, may be seen strings of Lapwings exposed for sale, and this will continue till far on in next spring. May I make my annual protest against this mischievous traffic? Great Britain has held aloof from the Convention of Continental States formed for the protection of birds useful to agriculture. Her Government decided upon this attitude on the ground that Parliament had already effected by legislation most of the objects which the Convention has in view. But the continued slaughter of Lapwings is altogether at variance with-nay, is in direct opposition to the main provisions of the Convention. It is true that powers have been conferred upon County Councils enabling them to prohibit the killing, capture or exposure for sale, of Lapwings or any other kind of bird at any or every season; but so long as these powers are not exercised this senseless slaughter will go on. For, unhappily, there is a ready market for the carcases of these useful birds. People whose palates are so gross as to be gratified by the flesh of carnivorous birds eat Lapwings greedily enough. Why not compel them to be content with their eggs? seeing that every Lapwing destroyed means the preservation of hundreds of noxious insects, such as leather grubs, wiremorms, click-beetles, caterpillars, and such like."

In England drainage and the improvement of waste 
lands have caused its numbers to diminish, still it holds its own on most of our high-lying moorlands. In Scotland it is plentiful, and is even on the increase in many of the northern districts. Unfortunately, its eggs are in great demand. In Ireland this is not the case; the eggs are not sought after as they are in England, but the birds are netted in numbers for eating.

The Lapwing is twelve inches in length. It can be immediately recognised by the long pointed crest which begins on the crown, extending backwards and being slightly curved upwards at the end, resembling a good deal a waxed military moustache. This is black, as are also the brow, throat and breast; the under parts are quite white, the rump a brilliant rust-colour; the base of the tail white; the end of the tail is adorned with a broad black border. Mantle shining, iridescent black. Legs red, eyes brown and bright; beak shaped like a thick awl. Such is the appearance of the males; the female bird and its young are much plainer in colour, and have a smaller crest. The nest is placed in the reed-beds and in shallow parts of the marshes; it is simply a scratched out hollow bedded with dry chaff. The clutch usually consists of four pear-shaped eggs, which have olive-brown spots and flecks on an olivegreen ground. The young leave the nest as soon as they are hatched, sometimes even carrying part of the shell on their feathers. 


\section{7}

\section{The Common Curlew.}

(Numenius arquata.)

THIs bird takes up its residence with us in Hungary as a vistor only on its way during the long migratory journey, which extends from the northernmost parts of our hemisphere to the Nile.

Its habits are most varied, for it stays sometimes on the flat sea shore, sometimes on the border of the desert, sometimes on a rocky river-bank; with us it settles on pasture land, fallow fields, marshy flats, and lowlands. It destroys everywhere immense numbers of grasshoppers and beetles. Crickets are the food it likes best, but it also eats snails, and sometimes even frogs. It is, therefore, of great service to the farmer, more especially as it frequents and cleanses the fields in large numbers. It does not require much protection for it is an extremely shy bird, and he must be a clever marksman who can bring it down with a shot. But the sportsmen of the lowlands are even more cunning than the Curlew. At certain places they lure the birds with a decoy-a bird dried in the oven which is placed on the lake edge-and a pair of Curlews are almost certain to fall victims to the ruse.

Its call-note is audible at a considerable distance, floating pleasantly, something like a modulated human whistle: "Klowit!" or "Taue taue," and "Tlouid tlouid! Shepherds believe that when this cry is heard it foretells wind.

The Common Curlew is to be found in Great Britain, wherever there are sand and mud-flats, and rocks covered 
USEFUL.

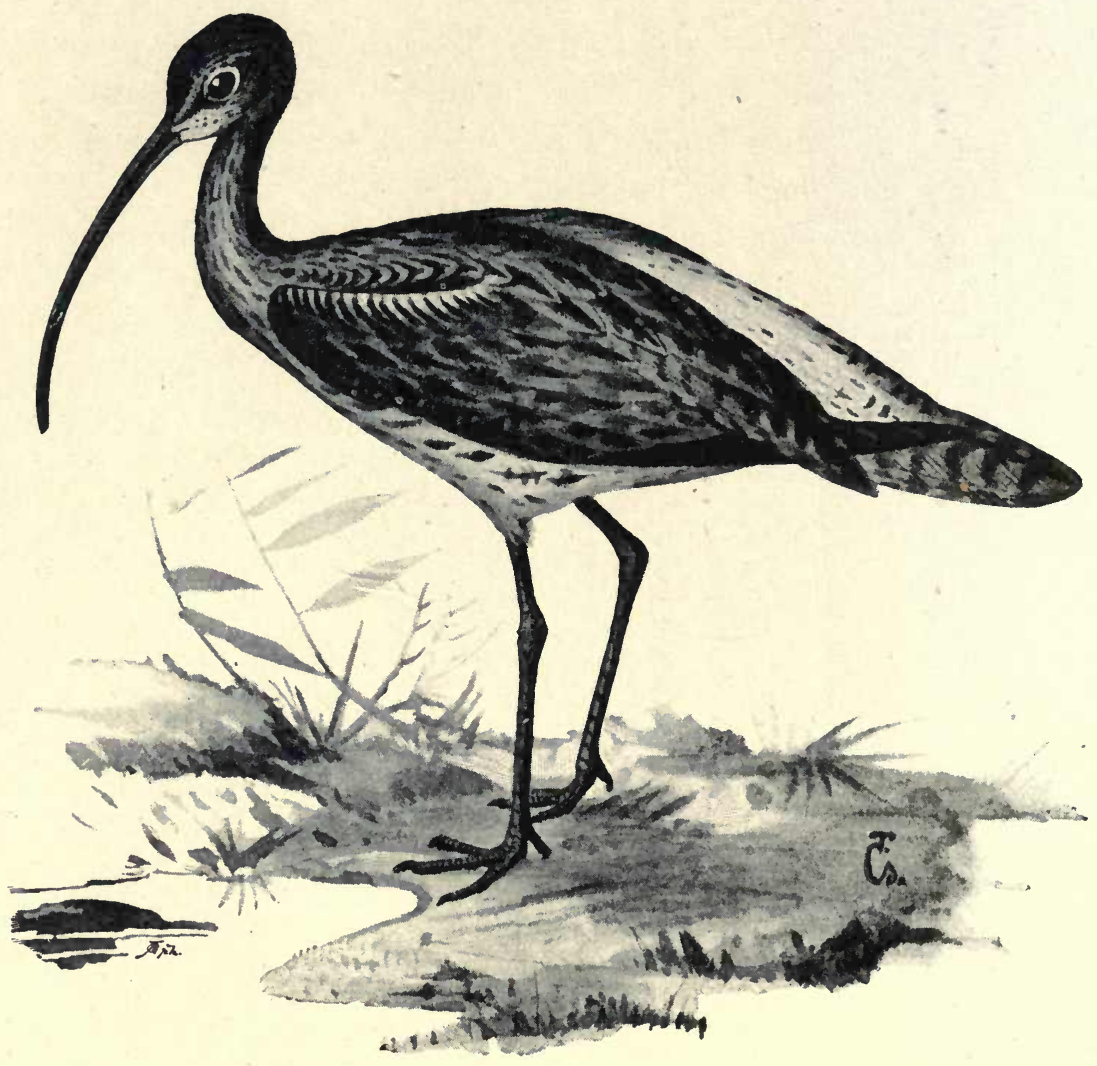

THE COMMON CURLEW. 
with sea-weed left high and dry at ebb-tide. It is with us during the entire year, for when the old birds go inland in spring, the young birds take their place and remain for the summer. As long as the young birds remain on the moors and pastures, their food consists of berries, insects, spiders, worms, and snails, and they then become excellent for the table; but after feeding near the sea, they become unpalatable.

Its plumage, mottled, speckled, and cut up with broken tones of brown grey white and light red, makes it look like a Plover when squatted, unless its long scythe-shaped bill can be detected,-a most difficult matter when in that position. It is wary in the extreme; morning, noon, and night on the alert. That it is brought to bay at times is certainly no fault of its own, but is mainly due to its surroundings.

The Curlew is a most interesting bird, see it when you may, on some upland with the sheep, in the grass meadows, or on the shore, when huge dark storm-clouds roll in from open water, a gale blowing, and the white parts of its plumage showing like large snowflakes as the bird and its companions are driven shrieking and wailing in all directions, or in the calm, still days of early autumn.

"From a fishing smack," says " A Son of the Marshes," I have watched it probing for lug-worms, running nimbly or walking sedately on the mingled sand and ooze.

Curlews allow themselves to be blown, or drifted only, when waiting over some favourite feeding-ground, before the tide has sufficiently left for them to feed. I have repeatedly watched mobs of them, waiting for the tide, when a heavy gale has been blowing. The birds know 
that their food is just below them so they merely flap to and fro and put up with the inconvenience of being blown about. At any other time they would shoot clean through in the teeth of the gale. Only those who have seen a frightened Curlew go up or down a creek lined with shore-shooters, shrieking as it flies, can form any idea of the bird's swiftness. I have known a bird of this kind "fly the gauntlet" for three miles, and there has been bang! bang! bang! from every shooter that it passed, good shots too. It escaped the lot without being touched. Swift flyers at all times, their ordinary speed is as nothing compared with what it is when they are frightened."

The Curlew is 24 inches in length. It has a long scythe-shaped bill, a long neck, and long, waders' legs. The plumage is marked with hemp-seed speckling, the specks somewhat elongated, here and there arrow-shaped. Tail white, slightly tinged with brown; every feather has brown bars. Eye brown. It does not usually nest with us, but is more a spring and autumn visitor; yet it sometimes happens that a pair of these birds build and rear their young. In its northern home it builds on the ground, on the moorlands. It lays four pear-shaped eggs, as large as those of the farmyard duck, of an olive green colour, with dark speckling. 


\section{The Common Redshank.}

\section{(Totanus cálidris.)}

THE Redshank enlivens whatever place in the reedland or marsh it happens to nest in by its voice and its varied plumage. It is a beautiful sight when it spreads out its wings, rises into the air and stretches out its long legs. Its resounding whistle is pleasant to the ear. It runs well, wades in water, and in case of need can swim. When the young ones are hatched, anyone approaching the nest should be moved by the wailing cry which it utters in anxiety for its young, though it has a thousand ways of luring people away from the nest and of misleading them, when it takes the trouble to do so. With a plaintive cry it settles on the ground, makes all.kinds of bows and curtseys, utters its flute-like note, then begins to run, as if to say, " Follow me, man!" When it has come out of the immediate neighbourhood of the nest it settles on a branch or a stake, or even attempts to perch on a telegraph wire. Then its voice becomes more plaintive even than that of the Lapwing. Even a - shot does not scare it away. - It moves away, disappears, but in a very short time it is back in the same place to continue its bitter lamentations; its note sounds like "Dlue, dlue, dlue, dlue-dee-dee-deedle-dee."

Like all the waders of the marshlands, the Redshank is very voracious, and has an excellent stomach. It devours beetles, grasshoppers and snails with great 


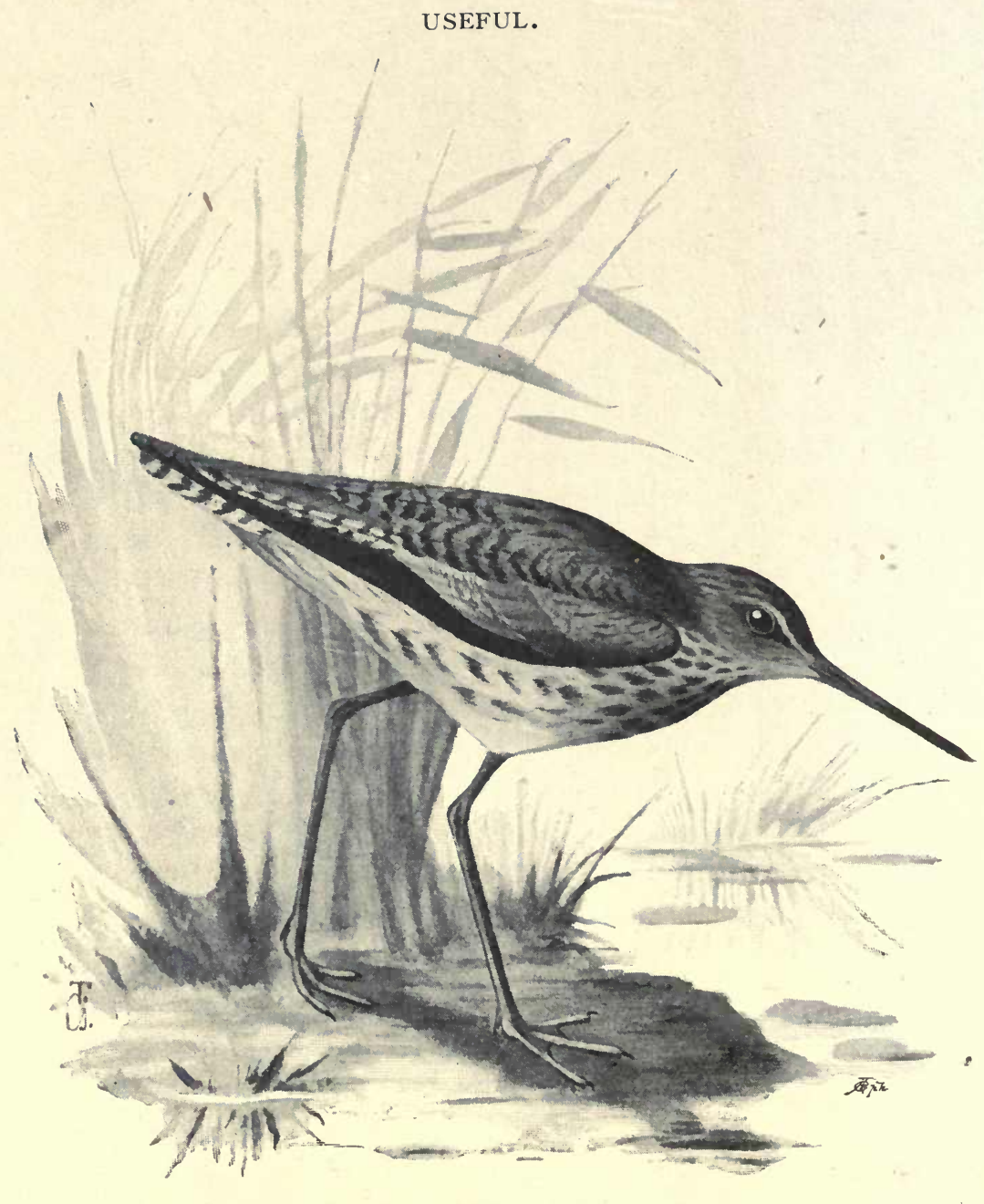

THE REDSHANK. 
avidity. All for the good of plants, and of men who derive benefits out of the sedge and reed beds.

This bird is a migrant.

The Redshank is still to be found breeding in most of the marshy districts in England and here and there in Wales; it appears inland from the middle of March, and early in autumn it begins to resort to the coast, being joined there by numbers of migrants from the Continent. When the winter is mild, birds are to be found throughout the year, more especially in the south and west. It is abundant as far as the Shetlands in Scotland; in Ireland it is fairly plentiful during the summer, and on the bays of the west it is numerous at other times of the year, wherever there is a sufficient supply of zostera marina left behind by the tide for it to feed amongst.

" Redshank, pool-snipe, teuke or toak, sandcock, redleg, redlegged-horseman,--all these names are given to him, as well as another, which exactly expresses the main characteristic of the bird-the yelper; and he certainly does yelp. When the tide is up all is level on the flats, even the blite is covered until the tide goes down. To all appearance the blite is left dry; but this is not the case, for thousands of small pools are left at the roots of the blite shrubs. These cannot be seen, because the thick grey-green leaves cover them. Most of the fowl feed in the numerous gullies that run through this salt vegetation. Some of the smaller kinds feed in the pools under it. If any web-footed fowl are about they are sure to pitch in one or other of the gripes and gullies."

The Common Redshank is eleven inches in length. 
Its plumage also has the hemp-seed speckling, but is more thickly speckled and barred. Beak long; legs long, of a bright orange-red. It is perceptibly webbed between the toes. Tail white, with dark bars. The dark wings are adorned with a white patch, the sides with pointed spots like drops. Its nest is found in wet marsh, or moorland, between the weeds and creeping stems, in little dips, and consists simply of straw litter. It lays four pear-shaped eggs, which are arranged in the nest. with the points towards one another. The ground colour is clay-yellow, and they are speckled with greyish and dark-brown spots and flecks. 


\section{The Green SAndpiper.}

\section{(Totanus óchropùs.)}

THE flight of the Green Sandpiper is very rapid; the note is a shrill tui-tui-tui. The food of the bird consists of insects chiefly, with small red worms and fresh water snails. It is not good to eat, having a disagreeable musty odour.

The Green Sandpiper is not uncommon in many parts. of England and Wales, on the spring as well as on the autumnal migration. On the east side of Scotland it is fairly frequent, but in the north it is very rare. To Ireland it pays unfrequent visits, even in autumn. "The Green Sandpiper is a restless bird, for ever moving on," says "A Son of the Marshes." "Something impels him to constant haste. . . . The first time I met him, unexpectedly, was on a breezy upland common, with just enough wind blowing to carry the white clouds along without blowing them to pieces, a few sheep were wandering about, their bells tinkling. On one side of the common are a number of old blackthorns, with wisps of wool sticking on their rough stems, then comes the long high-road, and close to the road is a small pond, gravel-edged, where the cattle that graze on the common come to drink. A shrill whistle, and in front of us is a beautiful bird. He runs a short distance, his feet just in the water, picks at something, whistles, and is off, over some old beech-trees. I have examined him dead, and have seen him and his mate exquisitely set up by a naturalist and bird-stuffer, but you must see him alive to form any idea of the dashing vitality of the bird itself." 


\section{USEFUL CHIEFLY.}

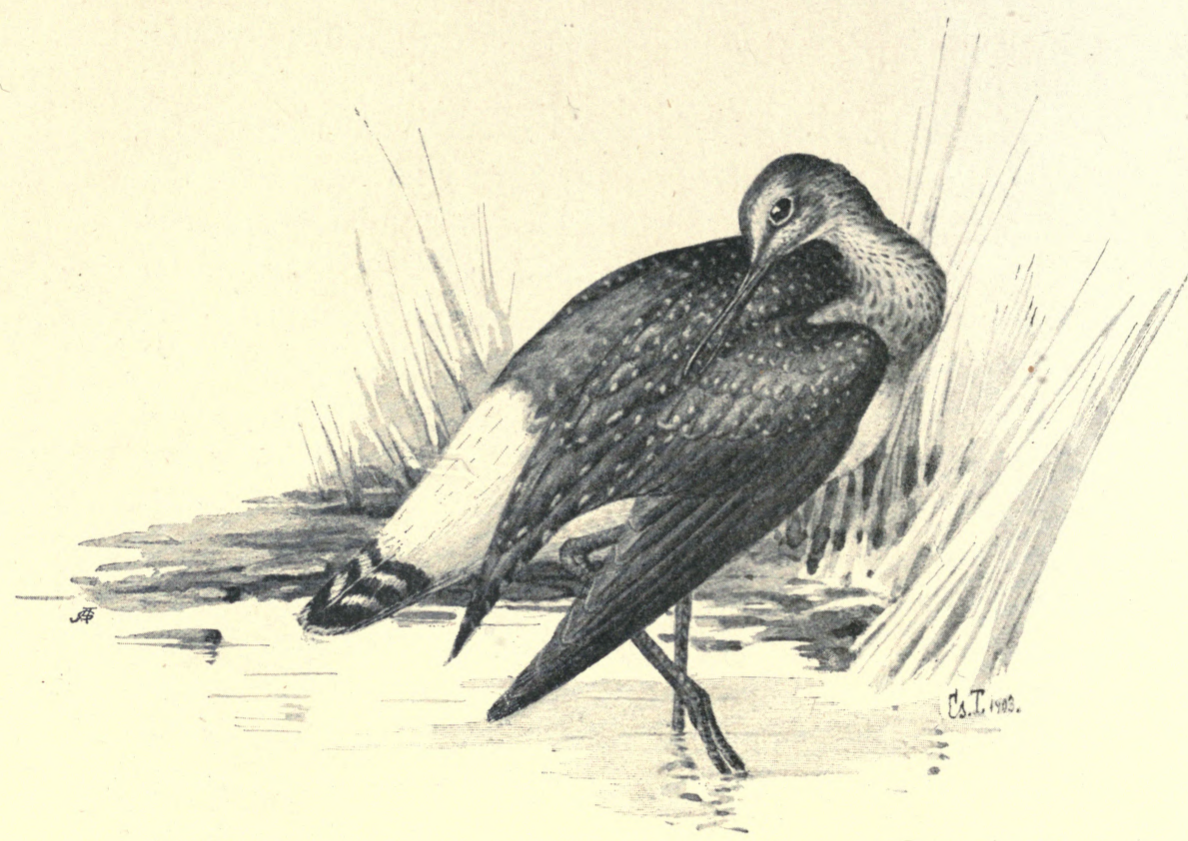

THE GREEN SANDPIPER. 
The eggs of the Sandpiper are rarely found with us, being laid in deserted nests of Crows, Woodpigeons, Blackbirds, Jays or Thrushes, or even old squirrel dreys; although its haunts are about the peaty swamps, hill streams and ponds. Its nesting habits differ from the others of its congeners. Its cousin, the Common Sandpiper (Totanus hypoleucus), is also a lively creature, that goes by the name of Fidler Willy-wicket, Dickydy-dee, and Water-junket. Fish is sure to be in the stream about which trips the Fiddler. Its note on rising to take flight is "Wheet! wheet!" and its alarm cry a shary "Giff! giff!" At Madely, in Staffordshire, a pair of these Sandpipers hatched out their young in a vicarage garden a few summers ago, the fact being recorded by the vicar, the Rev. T. W. Daltry.

In June you may come on a hen Sandpiper, with her young, beside some moorland stream. The little ones are precocious in their ways, and run about nimbly as soon as hatched out. The young of the Green Sandpiper are not so easy to observe.

The Green Sandpiper is a little over nine inchés in length. Upper parts olive brown tinged with metallic green, speckled and mottled, the lower parts white, so that when flying it looks like a black and white bird; the middle tail feathers having broad black bars, towards the end, the two outside feathers almost white. Feet greenish. The bird lays its eggs in old Squirrels' dreys, or the nests of Mistle- and Song-Thrushes, Blackbirds, Jays, and Woodpigeons; sometimes even on the ground, or on mossy stumps, and spines heaped upon fir branches, as high up as thirty-five feet but always near to pools. The eggs are light greenish-grey, with small purplish brown spots, generally four in number. 


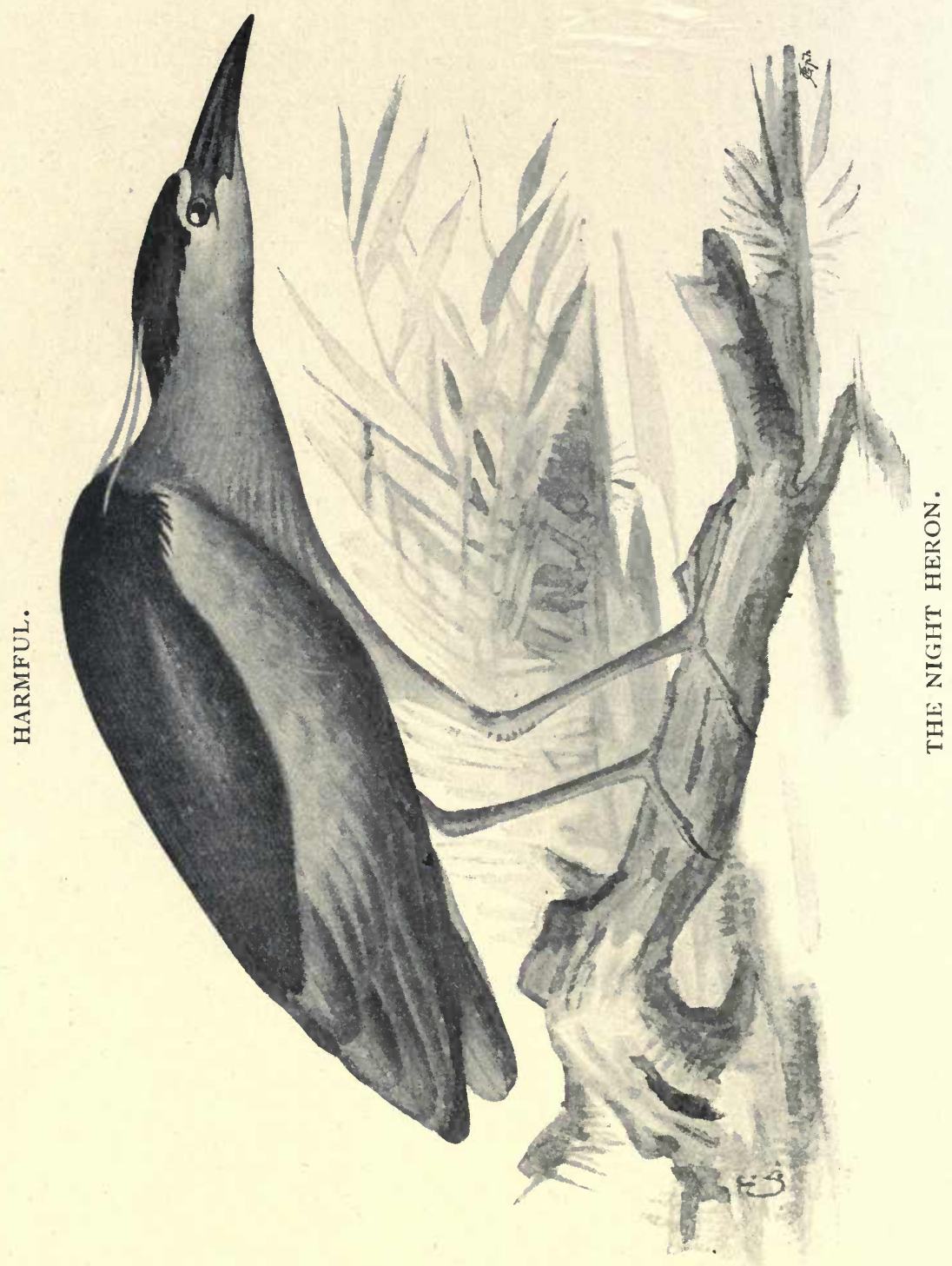




\section{The Night Heron.}

(Nycticorax griseus.)

The Night Heron nests with large numbers of its congeners in inaccessible spots in the marshes where marshy tracts and broom bush are close together. In such places will be found on each tree as many nests as there is room for. The nest itself is carelessly built of a few branches laid one on another, with a final layer of dry rush and sedge leaves. It contains four or five pale green-blue eggs.

It is not so secluded in its habits as the Bittern, and is not so fond of the broad open ponds and reed beds, but prefers the marshes, especially where there are slimy puddles, alternating with broken rushes, bushes, and trees. In such places it breeds, in great colonies, and watches for its prey, which it obtains from ooze-mud fish and other small fishes, water-rats, lizards, and all kinds of large insects. When flying, it draws in its. legs and head, and so scarcely looks like a Heron, but when it settles on a tree, as it often does, draws in its. neck and hunches itself up, it greatly resembles a Raven, whence it is sometimes called the "Nightraven." Also from its voice, which is like the croak of the Raven, and sounds like "Koā," " Koari,", or “Koay." Wherever the Night Heron settles it does much harm among the fish. It is not numerous in Germany; in Hungary it is. still fairly common, but with the draining of the marshes. the number of these birds is likely to decrease.

The Night Heron has been increasing in numbers in the British Islands during the last hundred years, so 
that it may now be ranked as an annual visitor to this country.

It is about 23 inches in length; wing 12 inches. The crown and nape are black with a green metallic lustre. Brow white, about the base of the beak. Two or three, occasionally four, snow-white feathers, pointing backwards, adorn its crown. The eye is large with a carmine-red iris; the long, pointed beak is black; the back is black with a greenish lustre; neck, wings and tail are ashen-grey. Underparts white, legs reddishyellow. The female bird is more uniform in colour. The young are speckled, while still in the nest.

The Common Heron (Ardea cinerea) is well distributed throughout Great Britain. There are, as before, when this bird was used in the old Falconty days, very many colonies, although these are not so crowded with nests as they used to be. The long-legged grey fisher is one of the most interesting sights beside our streams and meres. "Judy o' the Bog", is the name given to the Heron by the peasants in the south of Ireland. Young Herons were much in favour as table birds in the olden times. They are still eaten in some districts, but they are only good at certain seasons, if then; the flesh has mostly a very oily, fishy taste. The good this bird does in devouring water-rats, field-mice, worms and insects is counterbalanced by its depredations amongst the fish where the latter are a consideration.

Let me give here again a presentment of our Common Heron in the Marshlands of Kent. "An empty stomach has caused the Heron to leave his sanctuary in the Scotch firs that close in one end of the now frozen mere, and to come floating down to the river side. He has left bitter weather behind him, at any rate, for out in 
the west it is a cold steel-grey above, with a glow like that of the northern lights resting on the crests of the distant hills. For once he places caution on one side; one ring round directly over our head, and then he drops and folds his wings by the edge of a bit of water that is not frozen because it runs sharply over some shallows. The grey and white fisher has come here for his supper, knowing well that when waters are icebound, the fish will work up to any open piece of water, or even to a small hole broken through the ice, for air. They must have air; even eels, which are supposed to be able to live anyhow or anywhere.

To prevent him rising I take a wide range out in the water meadows, frozen down nearly two feet in depth; but I might just as well have been saved the trouble for a lot of rooks that have been trying to stock out a last scanty meal before roosting, from some manure heapsthat have been placed there to dress the meadow for the hay crop-come for him as one bird, and the lonely fisher is up and away again to his sanctuary in the fir trees." *

* "A Son of the Marshes." 
HARMFUL.

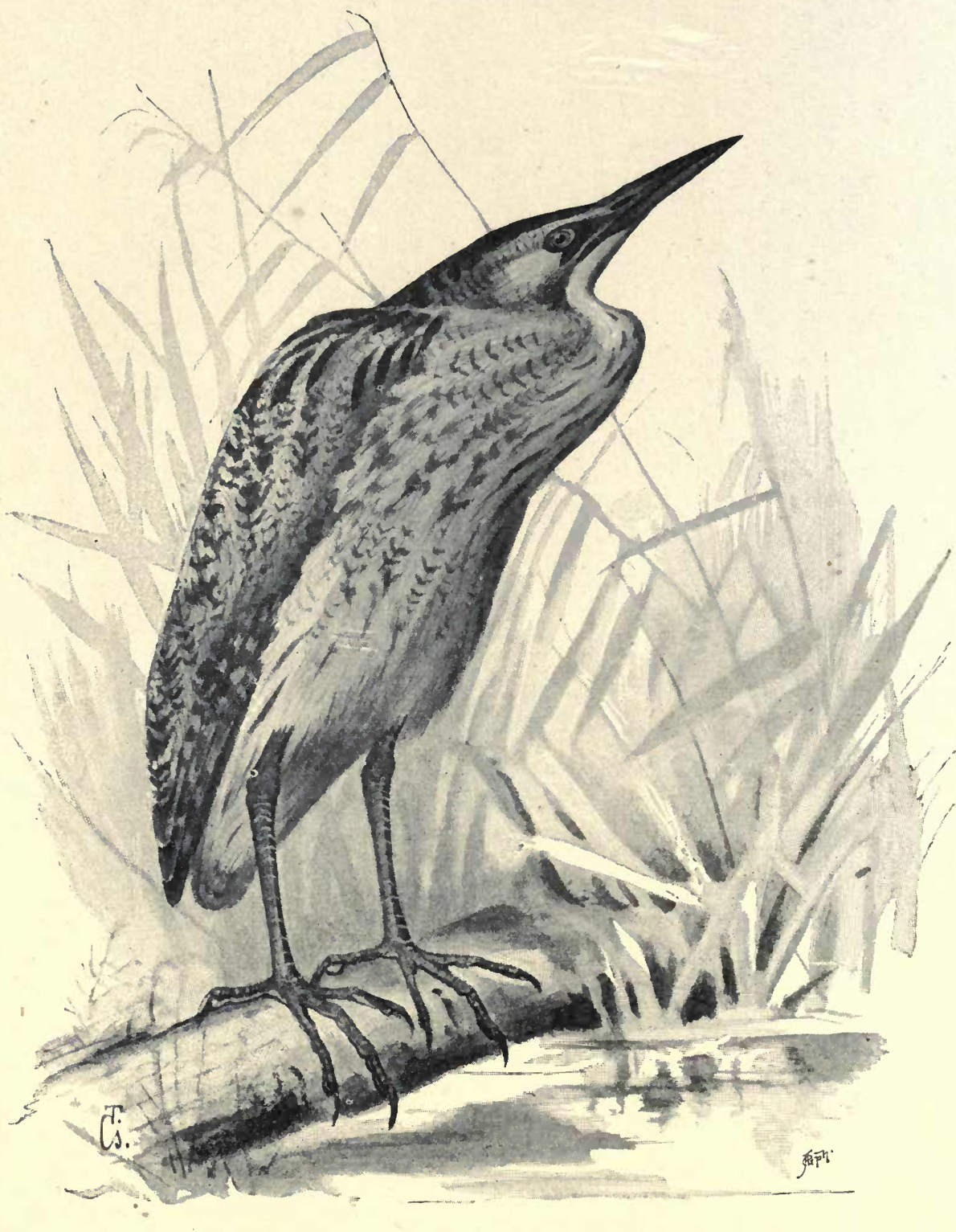

THE BITTERN. 
The Bittern.

\section{(Botaurus stellaris.)}

THE Bittern is a strange-looking bird which as it moves stealthily among the reed-beds, has given rise to many superstitions and weird beliefs. Yet it is nothing but a greedy, insatiable cousin of the Heron, living on small fishes, but not despising young birds, water-rats, waterbeetles, frogs, and even horse-leeches as food. Its eyes at once announce that it is a night bird. On a still night its booming can be heard more than a mile and a half away; and from this the bird has received some of its local names, such as "Bumble" and "Mire-drum." The sounds which it utters are deep, hollow roars, as though they came from some large animal; many people will not believe that these sounds proceed from a slender bird. They sound like "Cu-prumb-cu-prumm-cu-um." Sometimes, though not often, a "boo" is added to the "prumb." Learned scientific books have been written on the nature of these sounds. The truth is that they occur when the bird draws air into its feed-pipe until it is full and then expels it forcibly. In this way it produces its mating-call, the love-song of the male bird. It is not given to every bird to sing like the nightingale.

This deep-toned cry is rarely heard now in our British marshlands, where the bird now comes only to be shot and sent to the shop of the bird preserver. It has, of course, been getting scarcer every year. In Selby's 
time it was very scarce in some seasons, yet he records the fact that in the winter of 1830 to I83 1 ten bitterns were exposed for sale on one morning in Bath, and sixty were taken the same season in Yorkshire. "Butterbumps " was the popular name for the noisy bird, which, as some said, bellowed like a bull. The late Lord Lilford wrote that he knew a lady who said that when she was first married, about the year I845, and went to live in East Norfolk, she was constantly kept awake by the Bittern's booming in the neighbouring marshes. Tennyson's farmer called it the bogle.

Some of us were not sorry to hear that one of these rare visitors had been able to have its revenge on one of its persecutors lately. Being wounded only, it turned on the dog of "the man with the gun," who could not resist shooting a stranger, and used its strong bill and claws to good purpose. Its haunts are reed-beds, and the nest is composed of dried flags and reeds. Its flesh is said to taste and look like that of the leveret, with a slight flavour of wild-fowl, and to be more bitter eating than that of the young Heron. In the North Kent marshes Bitterns were called "Yaller French Herns," and the fen dwellers could get half a guinea for each bird. In France, of a coarse and stupid man, they often say, " C'est un vrai butor (Bittern);"' Molière says, "Peste soit du gras butor;" and Georges Sand wrote, "If your provincial bourgeois heard that, they would take our daughters for 'des butordes,'* such as their own are." Voltaire speaks again of "les butorderies de cet univers." In Saxony again the peasants say of a noisy brawler, "He booms like a Bittern.'”

$\because$ That a pair of Bitterns which had been observed for some little time on an estate near Hertford should

* Noisy, coarse creatures. 
have been shot lately, 1908, and that just before breeding season, is a fact to be deplored. I saw a beautiful specimen in Berkshire that had also fallen to. the gun of a collector. With the advance of civilisation and the drainage of the fens we cannot, of course, expect to have Bitterns nesting in our country again; but our children will we trust, be educated, in these days of Nature-Study, to welcome rare visitors, whilst respecting their right to live. Molluscs, frogs, lizards, small snakes and insects form their diet, and these we can all spare; and we should protect a vanishing species. A nest was taken in England in r868, but we have not had a later one recorded. A friend of the late Lord Lilford, writing to him, said: "My brother and myself, about the year I825, shot seven Bitterns in a field." This was at Holme Fen, near the New River. "The Son of the Marshes " says : " The Bittern is the bird of desolation, and it is in desolate places you will find him if he is about at all. All his habits are secretive ones. As a rule he comes out with the marsh owls. His plumage mimics the marsh-tangle perfectly, and the Bittern draws himself up by the side of that tangle, his dangerous bill pointing upwards in a line with the great rush stems, so that you might be within a yard of him and yet not see him. Frequently it has been the case that shooters have had these birds clutter up close to their feet."

The Bittern is 28 to 30 inches in length, but its loose feathers, long neck and thin legs make it look much bigger. The arrangement and colouring of the plumage are not unlike those of the Ow1; it is yellowish with brown speckles. Bill yellowish-green, but the back of it brown. The legs are also yellowish-green, and have 
long toes. Eyes yellow, as in many owls. The bird can draw in its neck and cover it with feathers in such a way that only its long legs betray its species as being that of the Heron. The nest stands always alone in thick reed-beds near standing water. The eggs are usually three to five in number, and are pale bluishgreen in colour. 


\section{The Waterhen or Moorhen.}

\section{(Gallinula chloropus.)}

THE Waterhen likes ponds surrounded by thick bushy growth and builds its nest on the edge. It clambers nimbly about the reeds, and also swims very well although not web-footed; it dives, and is able to remain some time under the water. It does this when pursued, only occasionally sticking its bill out of the water to breathe. It takes long strides when walking, and can run fast, can stand on the broad round leaves of water plants, on the water grasses, and floating rubbish, its long toes preventing it breaking through and sinking in. It is a very pleasant bird, and if left alone becomes very confident, and it is then an ornament to its sur-o roundings. Its food consists of insects and water-wort; it also rips off the points of sprouting rushes, and the fleshy sedges. In fact it is an innocent and indeed a useful bird.

The little tail is always turned upward, both in running and swimming, and with each movement it nods its pretty head. It is a truly charming sight when the Waterhen first takes her eight or ten black, silky, roguish-eyed nestlings to the water-each one being about the size of a walnut, they bob about like so many black corks.

This bird is worthy of every protection.

The Moor or Waterhen is well distributed throughout the British Islands and it is, as a rule, settled in its habitat although in severe winters many migrate from the northern to the southern parts of the country.

When the sooty chicks are out, the Moorhen parents 


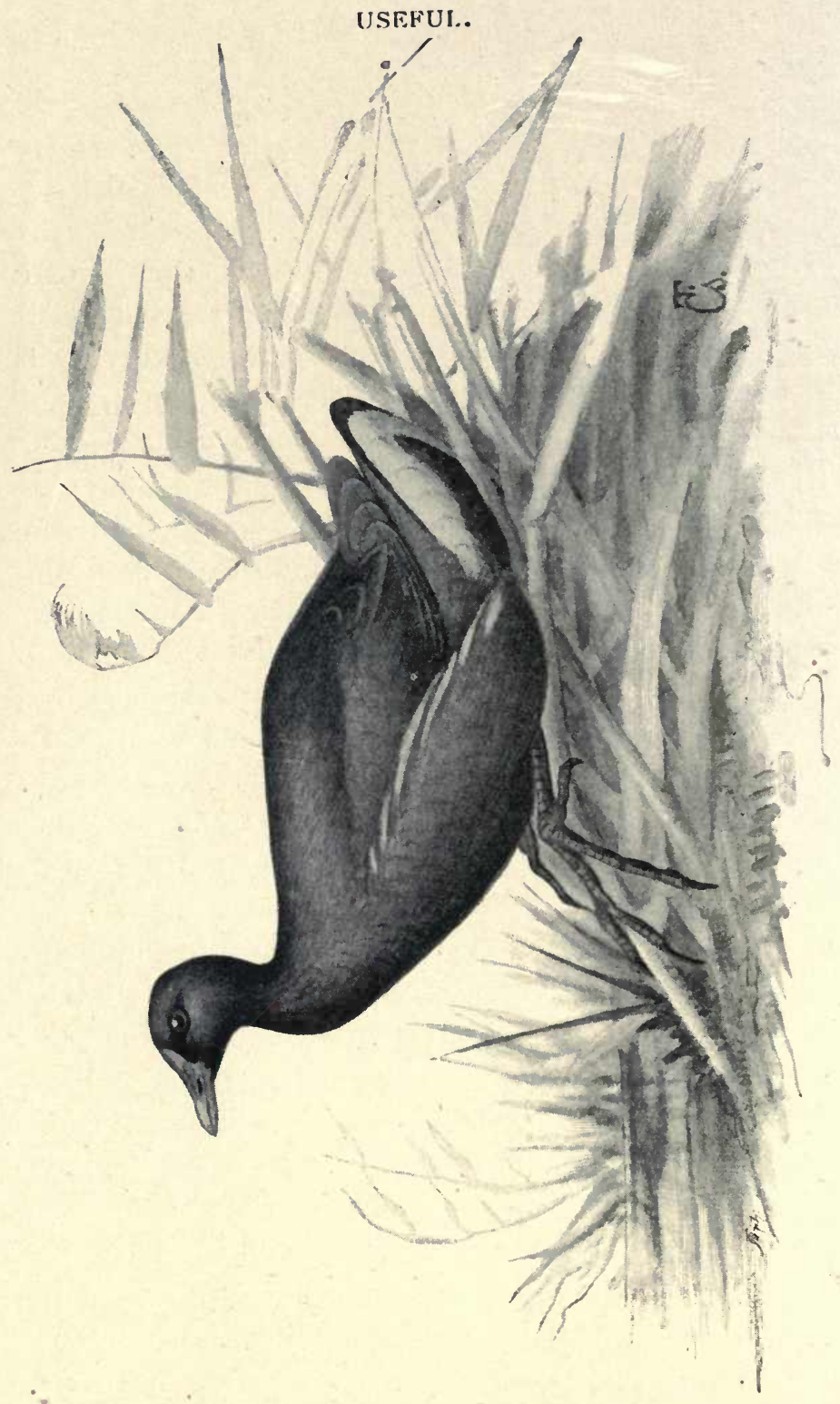

THE WATERHEN OR MOORHEN. 
have a very anxious time of it, for the Heron is on the look-out for them, and he does a lot of wading in the reeds and the swamps all the time the young Moorhens are about. They would be far more numerous were they not hunted for, so persistently, by furred, finned, and feathered prowlers.

The Pike is one of their worst enemies, and the youngsters are kept often in about three inches of water to escape his murderous bite.

"The Moorhen can both swim and dive, and he flies well when fairly on the wing; but as his real flights take place, as a rule, at night, very little is known about them. I once saw a flight at daybreak that very much ast-nished me. The bird shifts considerably about at nignt at times. When alarmed it is occasionally very clever in concealing itself, and it will sham death to perfection, even when caught alive by a good dog, without a feather being injured."

The Waterhen is rather larger than the Partridge; it has longer legs, of a green colour, and much longer toes. It has a small growth on the wings like a spur. On the brow is a bare crescent-shaped red patch, the pupil of the eye is carmine; neck and the whole of the mantle dark, greenish-olive brown; the other parts of the body slate colour, the inside of the lower tail-cover being of a darker shade, with a broad yellowish white border. The featheis on the edge of the wings are tipped with white, forming a beautiful white line, to the front of the wings. The bill is green, red at the base. The nest is nearly always placed in dry sedge-bushes on the edge of the water; the dry grass serves for litter. The clutch consists of ten eggs, which have a pale yellowish red . ground speckled with violet and reddish-brown. 


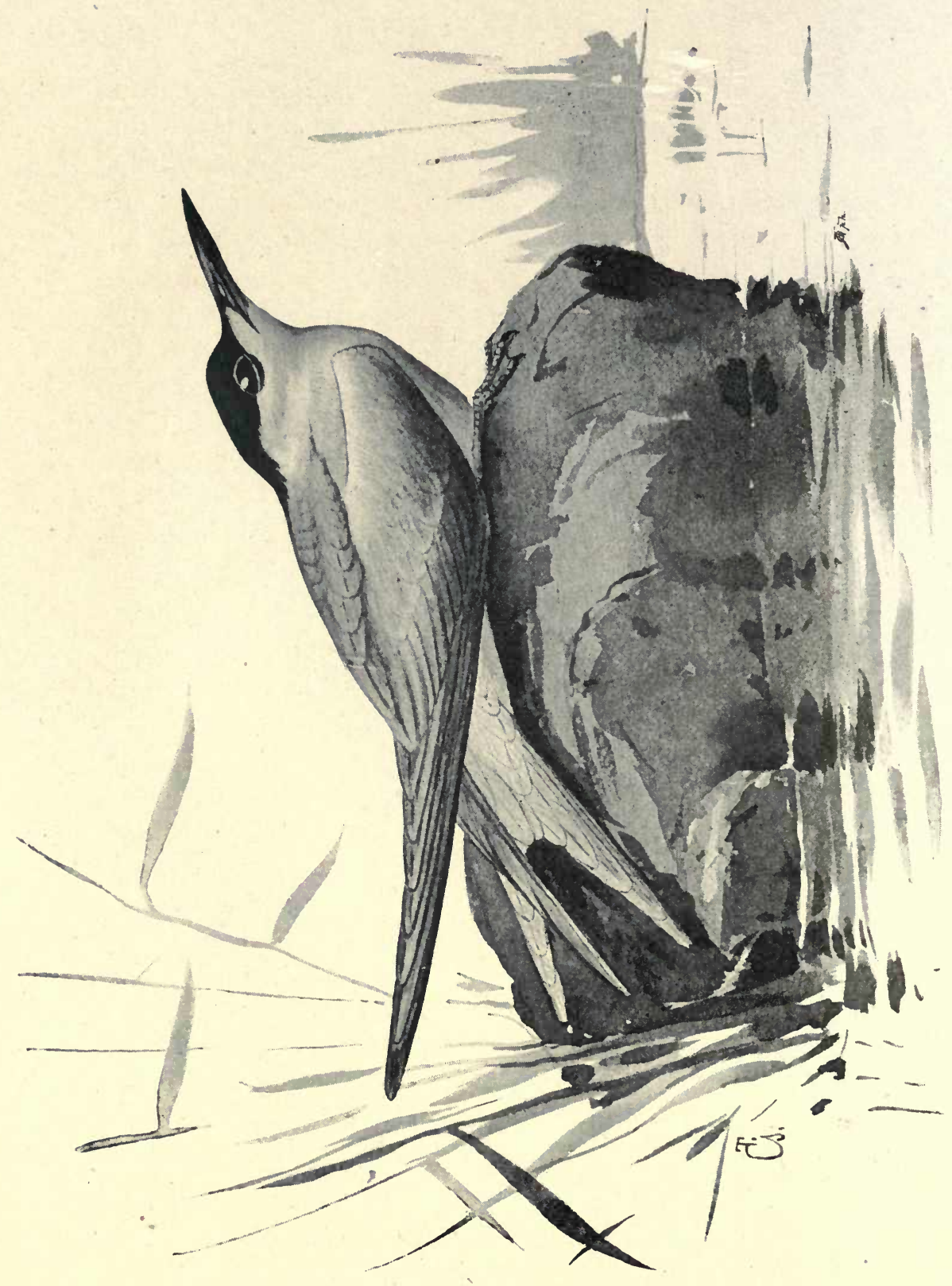




\section{The Common Tern.}

\section{(Sterna fluviatilis.)}

This birds nests in companies, in grassy places near a river bank, where a nest, without any foundation, is made, being a flat hollow in the ground. In this it lays two or three eggs of a clay- or brownish-yellow colour, speckled with violet-grey and brown. The Tern is a real ornament to our large rivers and lakes, with its guileless nature and its fine swinging flight. If it were to disappear we should lose one of the joys and beauties of life. All day long it flies over the water, with only short intervals of rest which it takes on a gravel heap or a hurdle, with neck drawn in and pointed upwards, only turning its head now and then to look at the water. It constantly flies at the same height, and as soon as its prey comes to the surface of the water it spreads its tail stiffly downwards, and hovers, beating with its wings, and gazing fixedly on the spot where the victim showed itself. Then, suddenly, it drops like a stone, with a loud splash, into the water. It has then secured its booty, usually a small fish. Its usual voice sounds like "Kriey" ; sometimes, when in trouble, it utters a light "Kek" or "Krek." It is not common enough in Hungary to do much mischief.

In Great Britain we find the Common Tern along the shores of the Channel and up the West coast as far as the Isle of Skye, and again from the Moray Firth down to Kent. In Ireland it is plentiful in the South. " Three species at least of the beautiful terns, well within my own time, bred freely in this country; but their colonies on the flats and the foreshores have been harried 
for eggs and birds so persistently, season after season, that they have ceased to exist as breeding places. A few hatch out in lonely shingle runs here and there on the coast lines; others have changed their breeding grounds. for good. The ring-dotterels have suffered in the same way, but, from their different nesting habits nothing like so much as the terns have done. When dogs are trained for egg hunting, and the capture of young birds alive, without hurting them, is it to be wondered at if the poor birds shift elsewhere? The size of a place has nothing to do with its nesting capacities; if the conditions are favourable, there the birds will come in their seasons to settle down. If they are not interfered with they will come again, until at last you may count on their arrival almost to a day. One place I frequently visit, where the birds, water-fowl and waders have been protected for forty years, not by keepers or lookers, but by the people that pass that way, because the owner of a fine sheet of water desired that they might not be frightened. This is as it should be, yet for all that they are wild birds pure and simple, free to come and go just as they please, according as their inclinations move them.",*

The Common Tern is 14.25 inches in length but its long wings and tail make it appear larger. The legs are red, the feet webbed. Beak red with a sharp point; crown and nape quite black; mantle a fine bluish grey. Throat and breast beautifully white; wing feathers darkish. Tail forked like that of the House Swallow. The longest, outer side feathers, which form the fork, are dark grey, the other tail feathers, and the rump white. The eye reddish-brown. 
The Bean Goose.

(Anser ségetum.)

THE Bean Goose visits us only in winter, for it breeds in the most northern portion of our hemisphere, whence it is driven to our milder regions by the extreme cold of winter. Here it waits for spring, then it hurries back to its breeding place on the coasts of the Northern Ocean. It lays seven to ten white eggs in its simply-formed nest in the inhospitable desolate land of its birth. When obliged to leave the nest it carefully covers up the eggs. is order to preserve their warmth.

These birds move southwards in great flocks towards. autumn. Some of them come to us, and in many places. cover the fields in swarms, and in the case of their settling constantly in the same places, they may do considerable harm by nibbling, tearing up and trampling over everywhere generally.

When the winter is very severe here, and the seeds are covered with a thick layer of snow, Geese go still further south, some of them even crossing the Mediterranean; but they return directly the weather becomes milder. From this comes the shepherd's prophecy: "When the geese go south we may expect great cold; when they go north warmer weather is coming." The birds. assemble in great flocks,- - usually at the beginning of March, if wind and weather are favourable - and return to their home, where, separating into strings, they scatter themselves over the Polar regions.

This is the "Wild-goose" as known to shore shooters. It does not breed in our islands at all, but comes to us in 


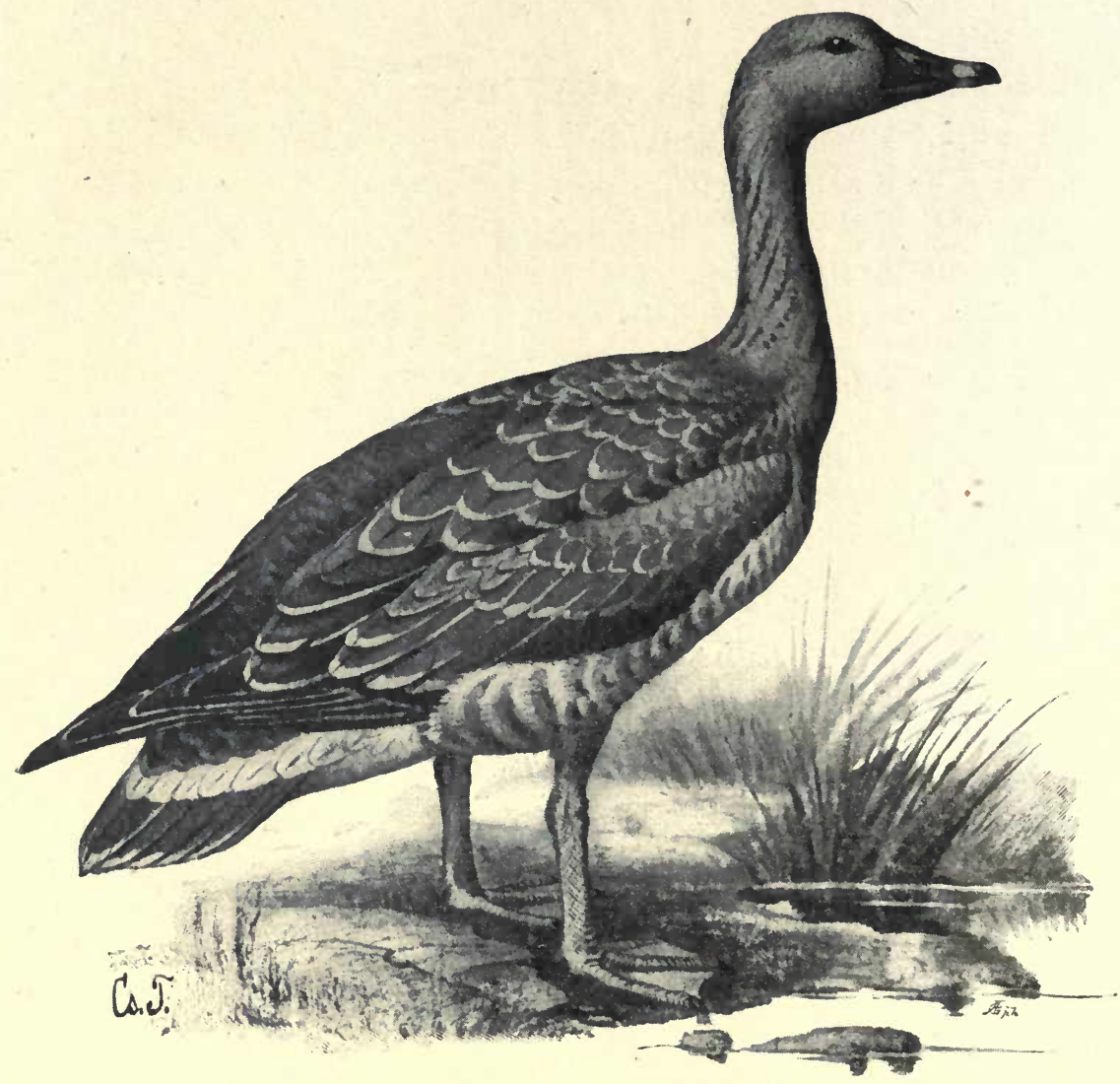

THE BEAN GOOSE. 
the autumn, and is to be seen in numbers on some of our coasts all through the winter. In cold weather it is fairly common on the mainland of Scotland. From autumn to spring it is found in all parts of Ireland, and is the commonest of the inland feeding Geese.

"Very awkward mistakes, and sad ones too some of them, have been made sometimes when these birds have been feeding on the saltings and marshes close to the tide, for at certain seasons the Geese will feed at night and then is the time to go after them. On one occasion a fowler shot his horse by mistake, and at another time a man shot his own son. Such incidents were once only too common. Fowl, feeding at night, bunch themselves up, taking strange shapes, and when alarmed they run before flighting, but they are not very wary, nor have they the keen sight of other wild fowl.",

" Gabble-retchet" is the term applied to the cry of the Geese on flight. An old proverb says: "Its aye fine when the Goose honks (or cries) high." This in the Eastern States of America has been corrupted into: " It's aye fine when the goose hangs high," and is often taken as meaning when there's plenty in the larder.

This Goose is 34 inches in length. The beak is black, the knob of.it being orange-coloured, as is also a broad oblique stripe on the nostrils. The points of the wings when folded extend over the tail. The prevailing colour is brownish-grey; the edges of the feathers and the breast lighter. The flight feathers are dark brown, so are the eyes, legs reddish-brown. 


\section{HARMFUL.}

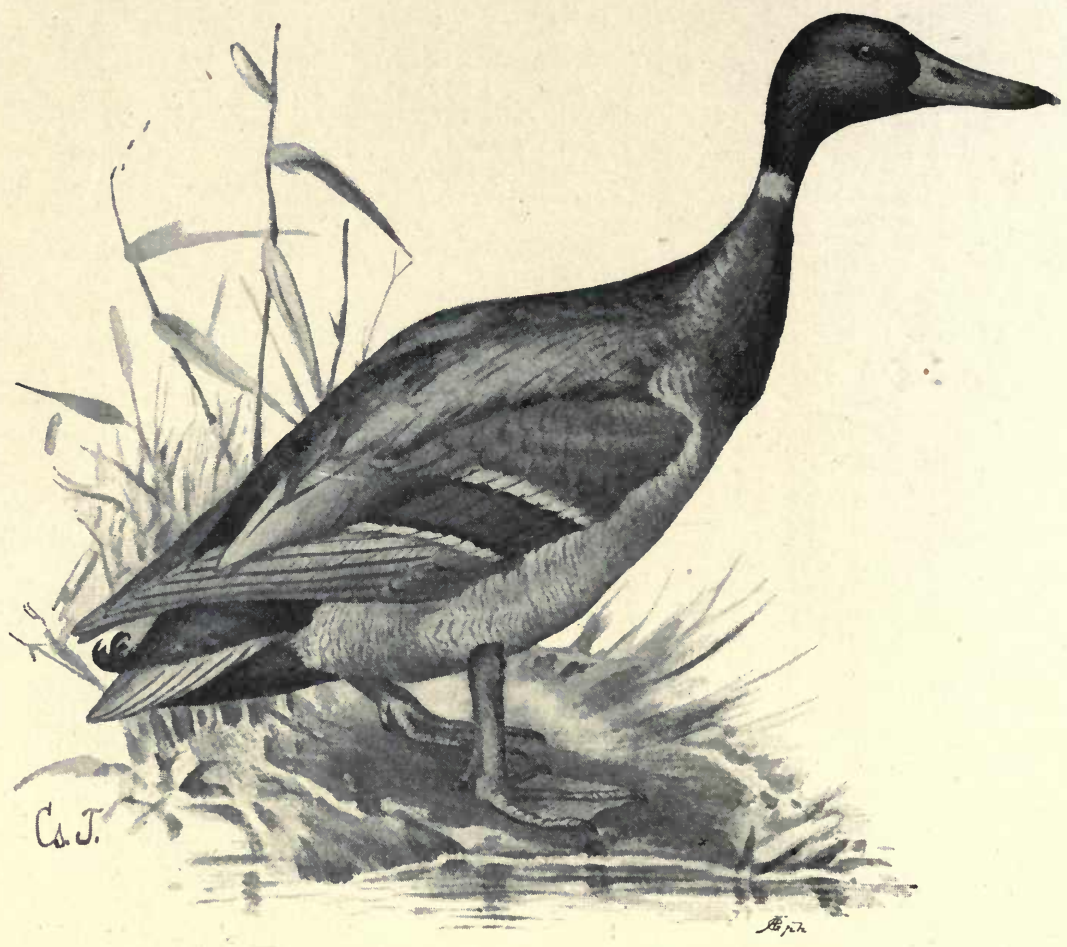

THE WILD DUCK OR MALLARD. 


\section{THe Wild Duck or Mallard.}

\section{(Anas bóscas.)}

THE nest of the Mallard is placed in the sedges of the marsh, in cornfields, and-strangely enough-on willow stumps and in large holes in trees. It is carelessly put together, but is lined with soft downy feathers. It lays ten or twelve strong yellowish-white eggs.

The way in which a mother Duck, who has nested in a tree hole rather high up, brings her young family to the water is remarkable. As soon as they are dry after hatching, she carries them one by one in her bill down to the water's edge. Each duckling as it is set down remains motionless as a stone on the ground, until the mother has brought the last baby to join the others, then the whole family begins to cackle and pipe, the young ones follow their mother into the water, swimming at once, and their duck life begins its ordinary course.

Their usual diet consists of water plants, duckweed, sundew, the green parts of the water-nut and the seeds of water grasses. They let the water flow, filtering through their beaks as beseems a well brought up duck, and in this way allow many little water creatures, fish spawn and such like, to enter their crops. But they can also do mischief. At harvest time the duck visits the cut corn lying on the ground and the sheaves, picks out the corn and treads down the ears. Therefore-and also because it is so good for the table-it is worthy of a well-aimed shot.

It is still very common in Hungary.

"Mallards manifest bird chivalry and courtesy to perfection-the clrakes industriously finding mussels for 
their sober-coloured mates, not because these are not able to find for themselves but because the males consider it their place to do so. Stretching out their necks and ruffling all their feathers they softly call when they have a lucky find; up rushes the duck, nips fast hold of the gaper and swings it from side to side as a terrier shakes a rat: after wrenching it from the shell she washes it in the water of the runnel and swallows it.

It is a matter of serious regret to many a sportsman and one entailing loss to the longshore shooter that the numbers of our common Wild Ducks or Mallards are each year becoming less. But for those bred in the Arctic regions-those the North Kent marshman calls " foreign flighters," we should be in a bad way as to the Wild Duck.

The latter arrive in great numbers from the Continent during the colder months. Drainage of the fens, and improvements in agriculture have, of course, lessened the numbers of those that breed with us; but flappershooting on the flats and the want of protection are decimating them largely on the Essex and North Kent marsh-lands. All good authorities on the subject agree that there ought to be a close time for our Wild Duck up to the Ist of September, whereas in Essex protection extends only to August I6th, and in Kent only till the I $3^{\text {th }}$ of that month. In shooting the Flappers, or young birds, many an old Drake gets killed; having lost his quills he is incapable of flight. He does not put on his full new dress until the middle of October. Flappers. are easily killed as they reach full growth before their wings are fledged; so that it is not really fair sport, which should give a free field. As old Peter Hawker, the father of Wild Duck Shooting said, flapper-shooting 


\section{THE WILD DUCK}

is often more like hunting water-rats than shooting birds. They haunt deep and retired parts of a brook, or stream, in families. Flappers are only called Wild Ducks when they take wing.

In the Fens formerly, until put a stop to by Act of Parliament, not only were Flappers shot as they are now, but an annual driving of the young birds before they could fly took place. A vast tract was beaten, and the birds were forced into a net placed where the sport was to terminate. A hundred and fifty dozens have been taken at once in this fashion. If our handsome British Wild Duck is to be preserved to us, further steps must now be taken to enforce and extend the close time for our home-bred birds of this species.

Both duck and drake are the size of the domestic duck, which is a near relation of its wild congener. It is the loudest cackler of the ponds. The drake has splendid plumage. The whole of the head has a fine green metallic lustre, this being separated from the rest of the colouring by a white band round the neck. A small bunch of feathers, curled upwards, stands on the rump, which is smooth black, as is also the under tail cover. It has a beautiful, lustrous violet patch bordered on each side with white, on its wings. Neck and breast are chestnut-brown; the mantle finely and beautifully spotted. The underparts light grey, each feather having fine dark stripes. Bill greenish; legs orange. The female bird is yellowish-brown speckled with dark brown. 


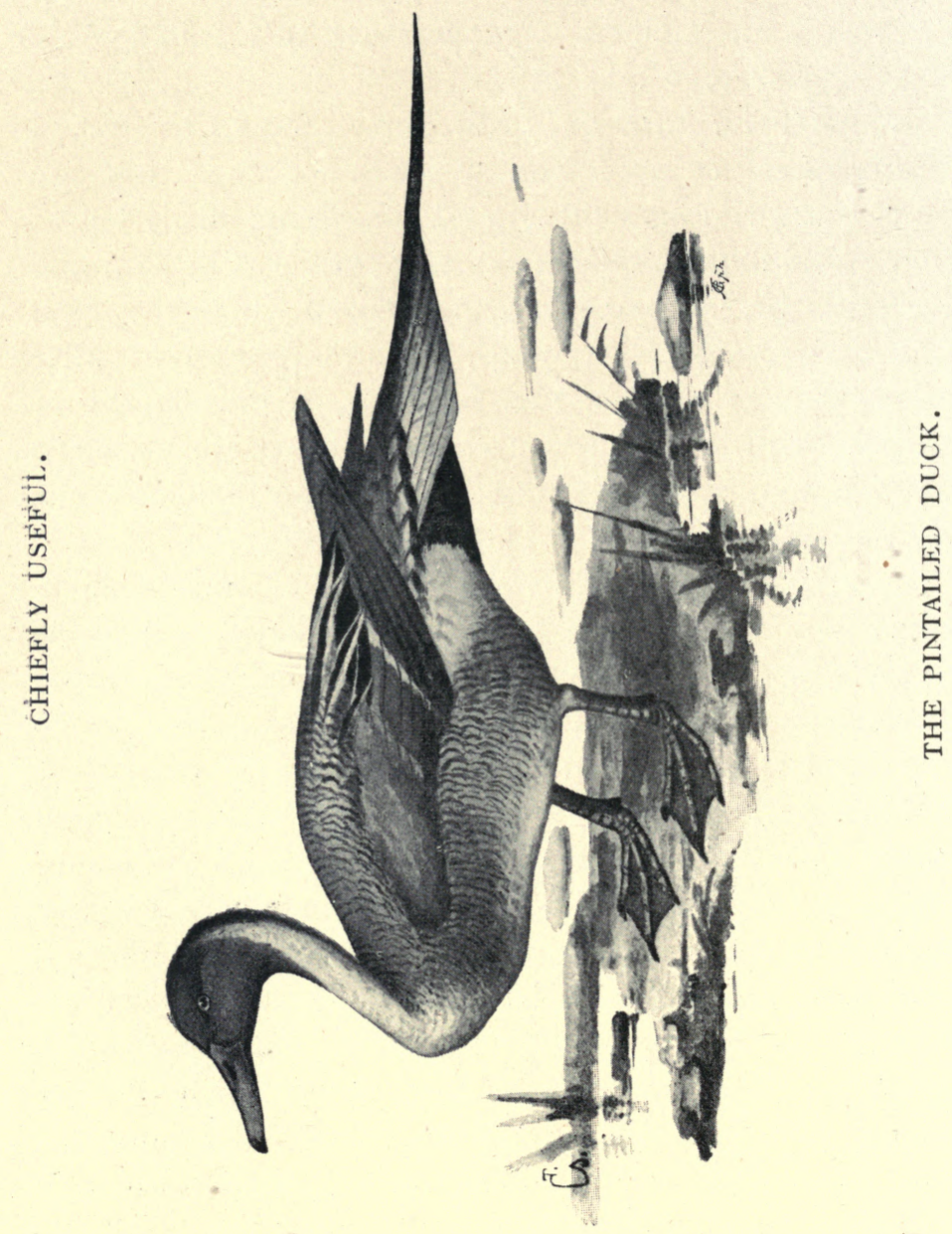




\section{The Pintailed Duck.}

\section{(Dafila acuta.)}

THE nest of the Pintail is placed among the sedges, rushes, and reeds of open ponds. The clutch consists of eight to ten greenish eggs, which are smaller and somewhat thicker than those of the common Wild Duck. It is a shy bird, difficult to surprise, which arrives here in large flocks, on its way elsewhere, only a few settling on large inaccessible ponds, or on the hidden pools hemmed in by huge reed beds, on the Platten See in Hungary, especially in shallow places where the white water-lilies and other water plants almost cover the surface with their leaves. In such places it pecks about the ground in the same way as the farmyard duck. Its food is tender duck-weed, and the young juicy shoots and points of water plants. But its most eager search is for water beetles, and the larvæ of dragon-flies and other such insects. As the marshes are drained and brought into cultivation the number of these beautiful birds decreases. It is still, however, not uncommon in Hungary.

This is a slender and finely shaped duck which is locally called the "Sea Pheasant." It comes regularly to our British Islands in October, staying in some districts longer than in others. In the North it seldom tarries long. Its favourite resorts are about our Southern shores and estuaries. When it is feeding the tail is raised high above the water, its head being below the surface. A hybrid between the Mallard and the 
Pintail, a half-bred drake, is a very handsome bird. Pintails have also been known to pair with Wigeons.

The Pintailed Duck is smaller and more slender, but longer than the Common Wild Duck. The middle tailfeathers are long-shaped like a spit or awl, and from these the bird derives its name. The neck is long and thin like that of the Heron. The drake has fine summer plumage. The wings have a shining metallic green beauty-spot bordered with red in front and white behind. Head a dusky-brown, cheeks copper colour. Throat white on either side, and black in the middle from the back of the head downwards. The whole of the underparts white, also the mantle, which is adorned with fine, close, dark wavy lines. The long pointed shoulder feathers are black with a white border. Tail nearly black, the middle pointed feathers quite black, and also the under tail cover. Legs bluish-grey; beak bluish, eyes brown. The female bird is like the female wild duck in colour but has the long tail feathers. 


\section{The Shoveler.}

\section{(Spatula clypeata.)}

THE Shoveler has a stately, direct, and rapid flight. It can be recognised by its great beak even when flying high. It is less timid than the other ducks, and does not go about in flocks, but if it does join flocks of other ducks, it flies somewhat apart from them. As its beak indicates, its food consists less of plants than of small living creatures of the pond and lake, fish, insects, shellfish, and other things which it finds in the water while it paddles around and lets the water run through the filtering edge of its beak. But the worst of it is this: The fish spawn in the shallow, tepid water near the bank, and there the young fishes are hatched. When the Shoveler comes to a spawning bed, in its voracity it destroys the young fish in thousands, before they are fully hatched. Thus it is a great pest to fishermen, and it is therefore fortunate that this bird belongs to the rarer species.

" Compared with the size of the Shoveler's paddles, its webs are small. Splashes and reed-beds are what it delights in. Many days have I passed where these birds could be seen. All sorts of flying and creeping things lived there; in fact the amount of insect life to be found in the haunts of the Shoveler would have to be seen, nay more than that, it would have to be felt, before it could be thoroughly believed in. Some sorts of insects have a very short play-time. Coming forth in clouds as perfect flying creatures, they fulfil the purpose they were created for, and then they drop down in the reeds, 
HARMFUL.

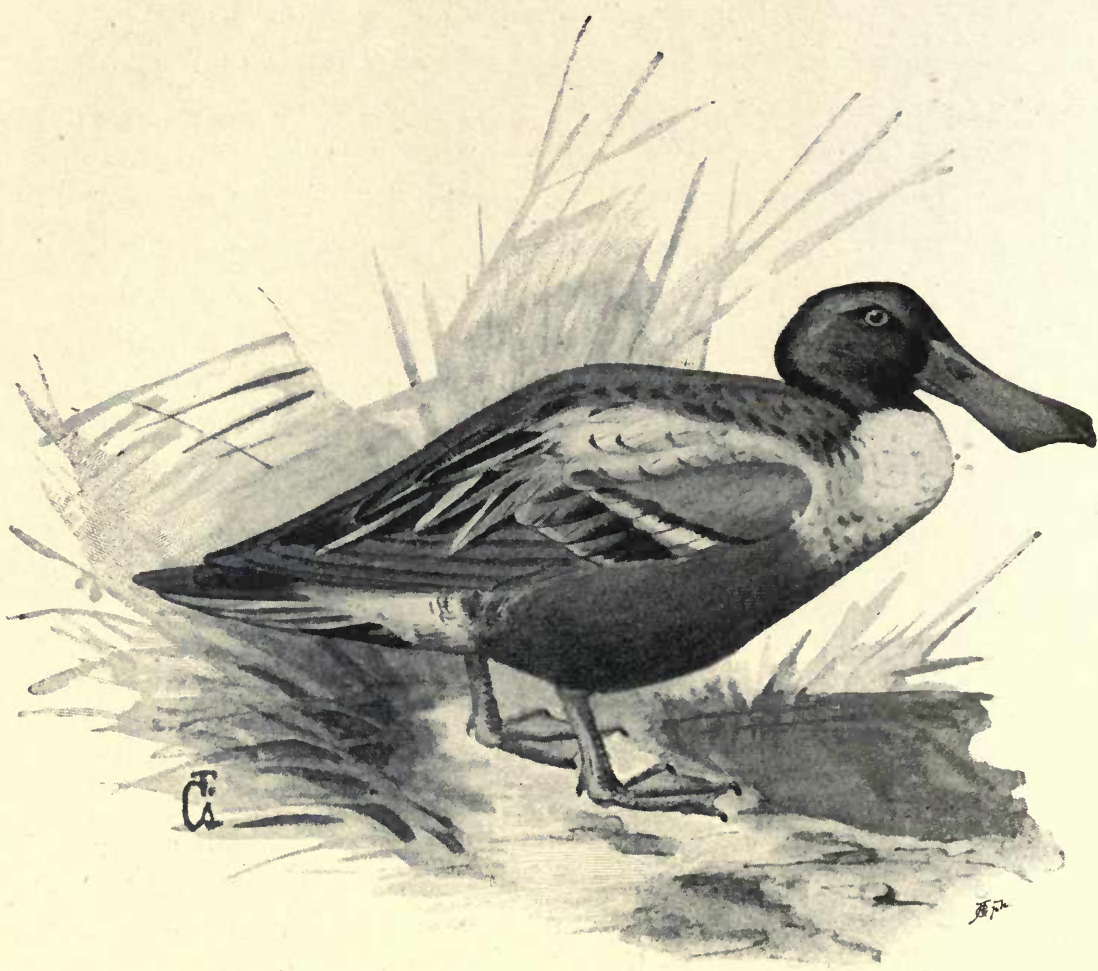

THE SHOVELER. 
or in the water either dead or dying. So thickly at times do these short-lived insects cover the water that, in places, the masses look like large patches of grey film.

This is the time for the Shoveler. He and his mate, will, so to speak, lay their heads and necks on the water, the lower mandible being just under water; and they will paddle along feeding as they go. These insects are part of their food in the season. Then too, they can probe and spatter on the edge of the reeds, where they find plenty of food, for the soft mud at their roots is full of the seeds of water plants growing below. As to the undeveloped forms of insect life, the light vegetable mud is full of these. So this handsome bird goes on his way very happily if not disturbed." *

Shovelers are plump ducks, and when their food is right are excellent for the table.

The Shoveler visits Great Britain during cold weather, and a fair number of the birds stay and breed with us.

The Shoveler is smaller than the Wild Duck and is more thick-set in build. Its chief characteristic is its powerful spoon-shaped, or rather shovel-shaped bill, which broadens out in front, and is furnished with a thickly toothed, comb-like arrangement on the inner edge which is specially adapted for filtering the water. The drake has beautiful plumage. The beauty spot on the wings is of a lustrous green, and has a white upper border, the wing itself is light blue. The sides of the head are bluish-green, with a fine lustre, the crop white. The forepart of the mantle is greenish-black, each feather having a white border ; rump bluish--black as is also the under tail cover. Shoulder feathers pointed, black and 
white, legs orange, bill dark. The female bird resembles the female wild duck in colour, but the broad shovel-shaped bill, immediately marks the difference between the two birds. The nest is placed in the boggy parts of the marshes and is formed simply of litter. The clutch consists of seven to fourteen rusty yellow eggs. 


\section{The Great Cresten Grebe.}

\section{(Podicipes cristatus.)}

The nest of the Great Crested Grebe is built of various decaying plants, and floats on the water. It is not found in the thick reed-beds; but on their borders, where the reeds are already beginning to shoot. There it so fixed to a single stalk that it remains in one place, and cannot be washed away. It usually contains four longish white eggs, which, however, become brown and dirty during the long sitting and rotten surroundings. The young birds are grey with dark stripes. In times of danger the mother gathers them. closely under her wings and then dives until the peril is past.

This Grebe is a remarkable diver; it dives with such lightning speed, that a shot aimed at it only strikes the surface of the water. It is a terror in the fishpond. When the fish feel secure, several of these birds join together and make a raid on them. They dive, and while under water drive the fish towards the shallow shore, and having thus placed them in a difficulty, the birds seize their prey from among the bewildered victims.

The Grebe endeavours to avoid danger to itself by diving, as long as it can-and it is able to remain under water for a long time and swim a considerable distance. If the rushes for which it is making, are still at some distance, it raises its head out of water for a moment, breathes once, and dives again. It is only in direst 
HARMFUL.

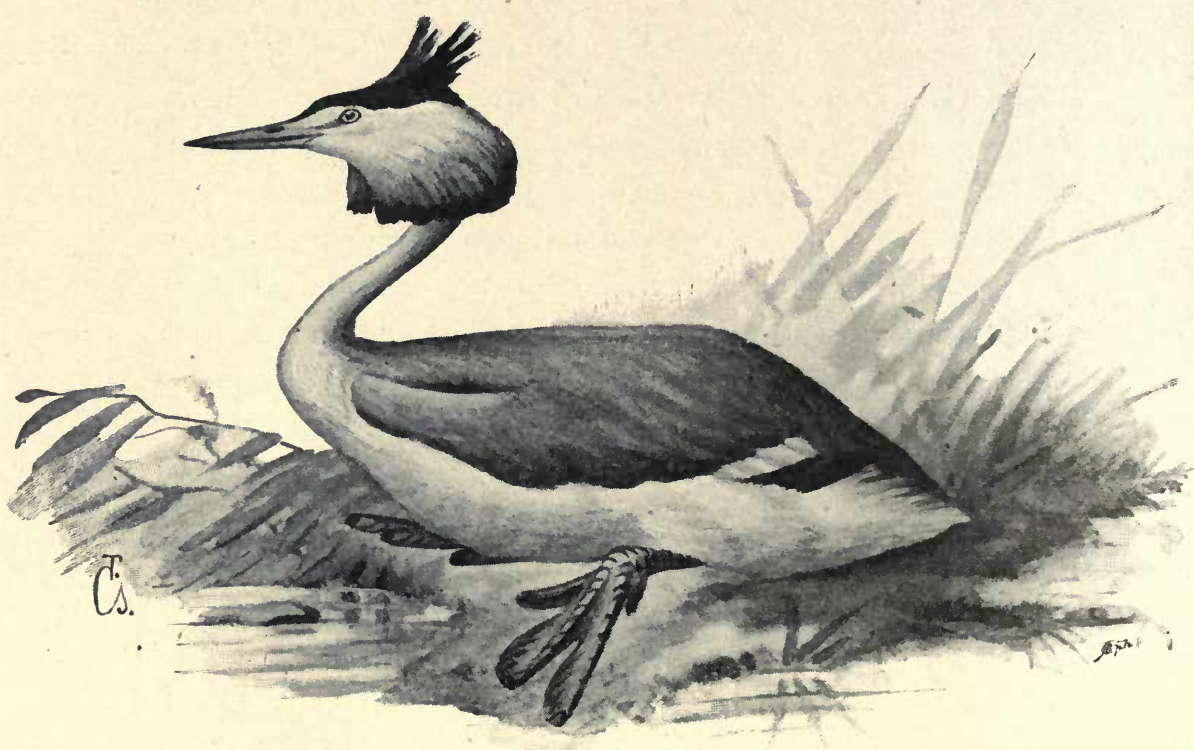

THE GREAT CRESTED GREBE. 


\section{THE GREAT CRESTED GREBE}

need that it takes to flight, and beats the water for some time before it begins to rise. Having once risen it flies rapidly and steadily.

Its powerful, piercing voice has various sounds. The call- note sounds like "Kekekeke"; during the brooding time its cry "Kroar" or "Kruor" is heard at a long distance.

The Great Crested Grebe is resident in Great Britain on many sheets of water where reeds grow in plenty, such as the Broads of Norfolk, the meres of Cheshire and Lancashire, lakes in Wales, and very occasionally only in Scotland. In the County of Stafford the Great-crested Grebe and Little Grebe, or Dabchick, are protected all the year round; and the meres in the West of Staffordshire, together with those of Shropshire, form one of the chief breeding areas of the former species of Great Britain and Ireland. On Trentham Lake, Dr. McAldowie has observed the Great-crested Grebe in mid-winter. They have also bred there of late years. On the rivers Dove and Trent, however, it has only been seen during the periods of migration. That it nests on the Lake Aqualate and on that in Trentham Park proves what the protection of landowners will do.

The Great Crested Grebe is the size of a Wild Duck but more slender. The general appearance of the bird, with its long outstretched thin neck is that of a longnecked bottle. It has on its black crown a double crest, forked and inclining backwards something in the manner of ears; on its neck, beginning at the back of the head and reaching to the throat, it has a red collar of split feathers with dark borders closely set together, 
which surrounds the sides of the head and the throat. The legs are constructed for propelling by a sideways stroke; instead of a true web, it has divided, crossribbed broad flaps on the toes, the pads of which are flat and broad. Beak sharp and pointed as a dagger; tail consists of a few little ragged feathers. The spot on the wings is white. The female has a smaller collar, and is more uniform in colour. 
An Elegy.

Our children will perhaps know less than we do of the delightful poems of Robert Burns, composed as so many of them were whilst he followed the plough, with ever a keen eye for bird and blossom wherever his work might lead him. I cannot resist quoting here that wonderful elegy of his :-

"Mourn, ye wee songsters of the wood;

Ye Grouse that crap the heather bud;

Ye Curlews, calling thro' a clud;

Ye whistling Plover,

And mourn, ye whirring Paitrick broo',

He's gane for ever !

Mourn, sooty Coots and speckled Teals;

Ye fisher Herons, watching eels;

Ye Duck and Drake, wi' airy wheels,

Circling the lake.

Ye Bitterns, till the quagmire reels,

Rair for his sake!

Mourn, clam'ring Crakes at close of day

'Mang fields o' flow'ring clover gay,

And when ye wing your annual way

Frae our cauld shore,

Tell the far warlds, wha lies in clay

Wham we deplore.

Ye Howlets frae your ivy bow'r

In some old tree or eldritch tow'r,

What time the moon wi' silent glow'r,

Sets up her horn :

Wail through the dreary midnight hour

Till waukrife morn!'” 
HARMFUL.

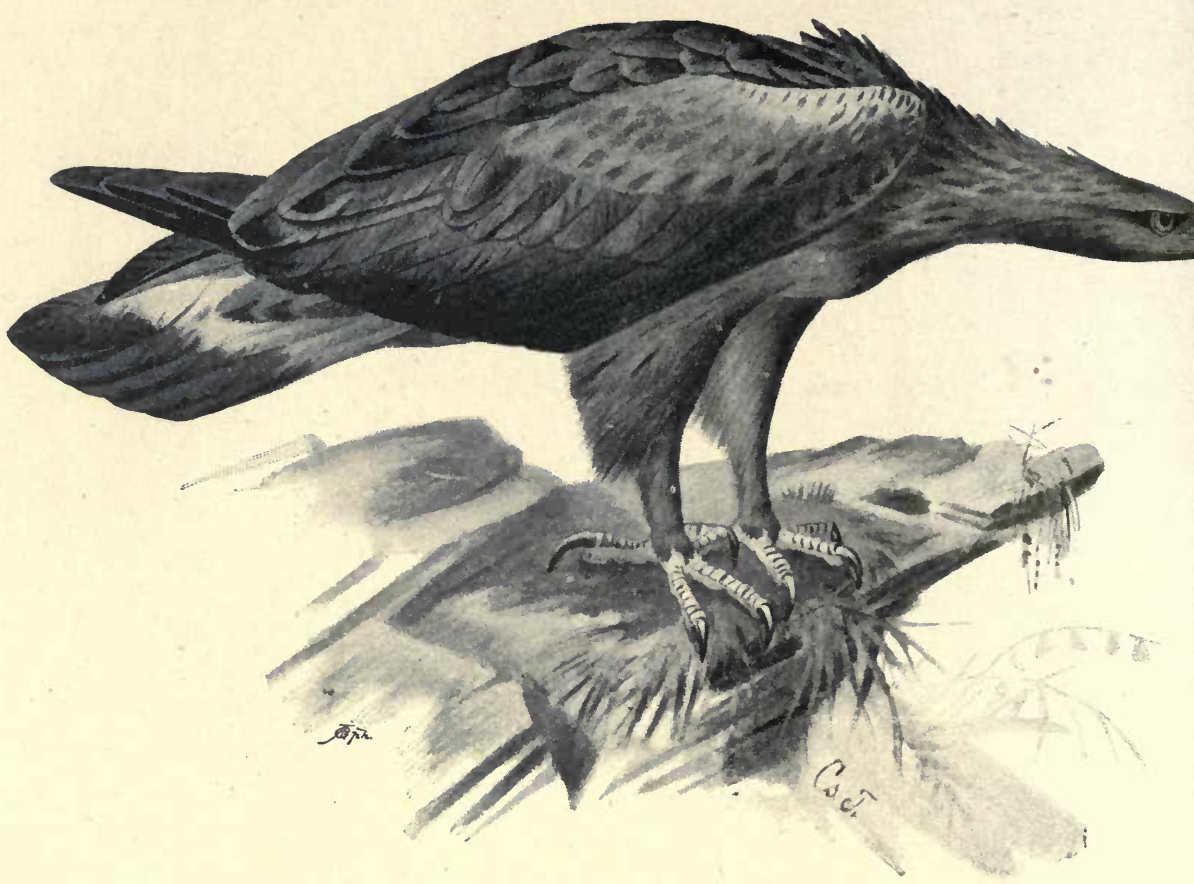

THE GOLDEN EAGIE. 


\section{CHAPTER VIII.}

\section{SOME OF THE FALCONID A.}

The Golden Eagile.

(Aquila chrysáëtus.)

IN Scotland the living prey of the Golden Eagle, called there the Black Eagle, consists largely of mountain hares, but it takes lambs, grouse and other birds, sometimes even fawns and the young of the red-deer. In Hungary he sweeps down towards autumn from the higher regions to the vast plains, where he works havoc among the smaller wild animals, especially the hares. Only when driven by extreme hunger will he feed on carrion. On sunny days he soars circling above, with shrill squeal, until quite lost to sight, looking as it were into the very face of the sun.

The breeding places of the Eagle are confined in Great Britain to the Highlands of Scotland and the islands of the Western side, and they are now protected by the owners of deer forests from the grouse preservers and sheep farmers who greatly thinned their numbers in former years. In Ireland very few pairs now remain; they were nearly all destroyed there by poison. They rarely visit England. So far from attacking any one who visits the eyrie or tries to take an egg or young, those who know them best say that they can be photographed without the least difficulty, in fact the old birds. will soar high above, seemingly ignoring the presence of the intruders. A visitor to one eyrie, in which was a 
baby Eaglet, found there four grouse, part of a hare, and a monk stoat! the latter, as the gamekeeper said, being an unheard of thing. Sometimes an enraged Hoodie Crow has been seen in full chase of a Golden Eagle which had been too near the nest and young of the former.

Mr. Seton Gordon says that when this Eagle is pursued by a small bird, the Mistle Thrush for instance, it never turns on its pursuer, although it could kill it with the greatest ease; but as he adds " in nature it seems to be the invariable rule that the pursued flies from the pursuer no matter what the relative sizes may be."

The Golden Eagle is now slightly on the increase in Scotland. It is a most interesting bird, the type of nobility and of valour. The naturalist with whom I collaborated over the signature, "A Son of the Marshes," has told of two live Golden Eagles which were chained to stands just inside the courtyard of the old coaching inn at Sittingbourne, in Kent, when he was a boy, objects of wondering delight to himself and of much daily curiosity to the passengers on the coaches. They snatched up more than one cat that came too close to their stands after the meat that was given to them.

Many poets have sung of the Golden Eagle:

" On sounding pinion borne, he soars, and shrouds, His proud aspiring head among the clouds."

\section{"Soaring}

With upward pinions through the flood of day, And, giving full bosom to the blaze, gain on the sun."

" Trying his young against its rays,

- To prove if they're of generous breed, or base." 
Somerville, in "Field Sports," gives some fine lines, descriptive of this bird, untamed though we call it, as one of sport :

" In earlier times, monarchs of Eastern race

In their full blaze of pride- a story tells-

Trained up th' imperial eagle, sacred bird.

Hooded, with jingling bells, she, perched on high,

Not, as when erst on golden wings she led

The Roman legions o'er the conquered globe,

Mankind her quarry, but a docile slave,

Tamed to the lure and careful to attend

Her master's voice."

This noble bird measures from 32 to 36 inches and the female is larger than the male. In reality he is about the size of a goose but his mighty wings and the breadth of tail make him seem far larger. The general colour is dark brown, tawny about the head and nape, hence his name golden. The tail has a greyish bar below, is mottled with dark grey in the adults, but the basal half is white in the young. The legs are feathered in front to the toes, thighs dark brown, toes yellow, claws hooked and sharp. The beak is curved from the cere. The brown eye is keen and strong as befits a bird who sights his quarry from afar. The nest, or eyrie, which is placed on a crag in a mountainous district, but often in a tree, is a large platform of sticks lined with softer materials. The Eagle never uses dead branches but always breaks them fresh off the tree. There are two and sometimes three dull greyish-white eggs streaked and blotched with every shade of reddish-brown and lilac. One of the eggs is generally addled. The young are covered with white down. During incubation the Eagle keeps near to his eyrie. 


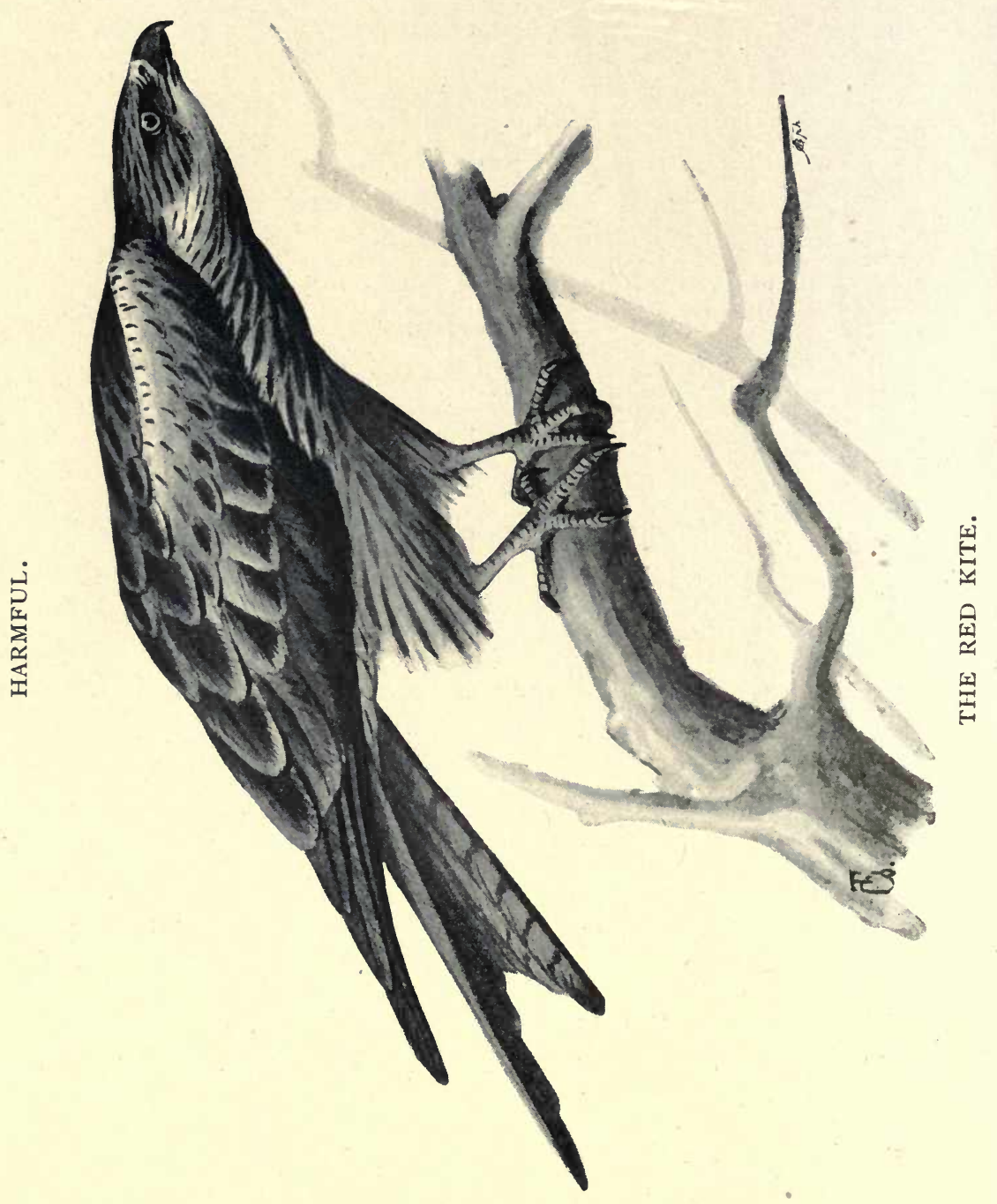


The Red Kite.

(Milvus ictinus.)

THE flight of this bird is very beautiful; it mounts in circles to a great height, but swoops down quite near to the ground when pursuing its prey. Its food consists of mice, lizards, adders, and unfledged birds; but most of all it likes poultry, hens, ducks, geese. In this way it is very hurtful. Fortunately, it is a cowardly bird, and a good clucking hen can soon put it to flight.

In the spring when the flocks of geese with their young ones are grazing in the tender grass, the Red Kite will suddenly appear and cause great consternation among young and old. The poor bare-footed guardians of the geese, strive to drive the intruder away with shouts, or by waving rags, and throwing stones; and though they generally succeed, the bird occasionally gains the day. This bird is nowhere very common, and is in any case only a summer visitor. Its cry is a shrill whér, heh-heh-heh.

This Kite was formerly known in Great Britain by its old Anglo-Saxon name of Gled or Glead, which comes from its gliding flight, and is styled Red Kite in order to distinguish it from its relatives. That it was once common enough in the South of England, a proverb, still used in the New Forest shows, "Yallow as a Kite's claw" the folk say there in describing one who has a jaundiced appearance. So common was it in the streets of London up to 200 years ago, acting the part of a scavenger in those days, that visitors from the Continent wrote of it. Some are now 
living who knew it as fairly common in the wooded parts of Great Britain-Ireland excepted-but the last nest in Lincolnshire, where it once was abundant, was known in r87o. In Wales, where a few still breed, the landowners are trying to protect what they consider an interesting species. The use of its tail feathers for salmon-flies brings about the bird's destruction in Scotland, and the gamekeeper is its pronounced enemy. In Ireland it has been seldom observed. Considering the adders, rats, and enormous numbers of mice the Kite devours, the term hurtful, as applied to it, ought perhaps to be modified.

A naturalist, writing in 1839 , tells how he once took away a young Kite from a nest containing two; it became very tame and would sit on his hand, never attempting to hurt him with its sharp talons. Sometimes he let it stray away and it always came home, though it might be out for a day or two; until it intruded on an old crone in her cottage. She quickly killed it as an ill-favoured fowl. I have seen a tame Kite swoop down during a circling flight and take a mouse from the hand of the late Lord Lilford as he sat, as was his wont, in his wheeled chair among his favourite birds.

Macaulay, alluding to the Kite's love for carrion writes :

" The kites know well the long stern swell

That bids the Romans close."

Wordsworth was familiar with it in his walks :

" Near the midway cliff the silvered kite

In many a whistling circle wheels her flight."

Robert Burns was not a friend of the bird, Quarles' " brood-devouring kite," for he likened the "father of all evil" to it : 
"Here is Satan's picture, Pouncing poor Redcastle

Like a blizzard gled, Sprawlin' like a taed.'”

But Hurdis was more kind and just :

"Mark but the soaring kite and she will read Brave rules for diet; teach thee how to feede; She flies aloft; she spreads her ayrie plumes Above the earth; above the nauseous fumes Of dang'rous earth; she makes herself a stranger T' inferior things, and checks at every danger.'

We may perhaps be allowed, by the chariest of agriculturists, to say that a species may be most undesirable in certain districts, but a welcome and even useful bird in others; and this is specially true of birds who devour carrion.

The Kite is about 24 inches in length. The back is rusty-red, the feathers there having dark shaft lines and edges. The tail is strongly forked. The female is less brightly coloured than the male and the young still less so. The thighs are clad with feathers, the legs bare, claws moderately strong and sharp. The bill is sickleshaped and has a yellow cere at its base. The irides are yellowish-white. The Kite is a keen-sighted bird of prey, and builds its nest for the most part on the highest trees in the woods. It lays two or three eggs, more rarely four, with dirty blotches, smears, and spots on a greenish-white ground. 


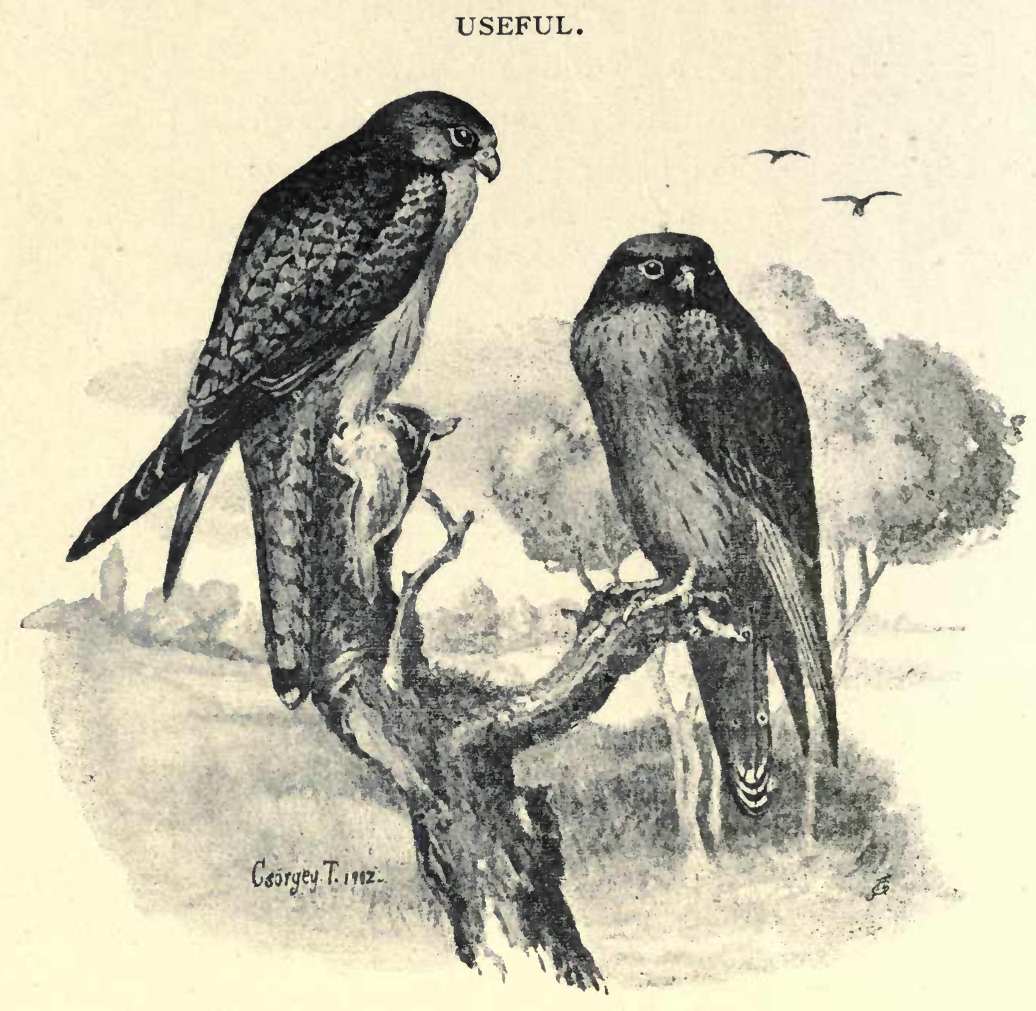

THE RED-FOOTED FALCON.

MALE AND FEMALE. 
The Red-Footed Falcon or Orange-legged Hobby. (Falco vespertinus.)

UNLIKE all the rest of his congeners this beautiful Falcon lives exclusively on insects. It is considered by the Mohammedan races as a sacred bird, on account of the way in which it destroys grasshoppers. Its flight is easy and bold, and the way in which he circles and floats in the air is beautiful. The young ones are also fed on insects, and as soon as they are fledged the little flock betake themselves to the meadows or the seashore and there begin with zeal their work of insect hunting. They settle on the meadows, on the freshly mown rows, and destroy the grasshoppers, and when there is a plague of these insects the Falcons are untiring in their work of extermination. It is one of the most gentle of birds, and the young ones when caught become tame in the course of a day. It can easily be seen from the expression of the eyes that there is no savagery at all in its nature. How different from the glance of the SparrowHawk! It is a remarkable characteristic of this bird that not only does it differ from others of its species in its food, but also in regard to its nest. As a rule, it does not build a nest, but occupies one, generally at the cost of a battle, belonging to one of a colony of rooks. The fight for the nest is a fine spectacle, for in it the bird exhibits to the full its fine art of flight. In Hungary it is a regular migrant, and arrives in fairly large numbers.

The Red-footed Falcon is only a rare wanderer to the British Islands on its migratory flight, and chiefly to England. One was recorded as shot in Scotland in 
I866 - another, which is in the Dublin Museum, was taken in County Wicklow in 1832. It is a pity that this useful species, living as it chiefly does on insects and field mice, should only appear in our country to be shot.

On the steppes of Orenburg in Russia it has decreased during the last fifty years, owing apparently to the immigration of great numbers of the Lesser Kestrel, which used to be rare there. The flight of the Redfooted Falcon is not nearly so dashing as that of the Kestrel; you can note a difference in the expression of the eye and the shape of forehead of the two birds.

The clutch of eggs numbers five to six. They are of a yellowish-white ground-colour, with spots and marblings, some darker, some lighter. The nest structure is scanty, and is seldom built by the bird itself; it appropriates the old nest of a Crow, Magpie or Rook. The male of this species is for the most part slate-grey in colour, the thighs and under side of the tail are bright chestnut-red. The iris and the feet are red. The colouring of the female is more diversified. The mantle is bluish-grey, with blackish stripes, like those on the tail; the sides of the belly are light rusty-brown, throat and nape white. The forehead is whitish; top of the head rust-coloured, legs and feet reddish. The claws are nearly white. 


\section{The Common Buzzard.}

\section{(Búteo vulgáris.)}

THis bird is equally at home in the plains and in the highlands. It goes South in the winter, except in mild seasons. Like the Kite it soars to a great height with a fine sweeping movement, crying "keo-keo." It descends and with an easy stroke hovers near the ground, from which it seizes frogs, lizards, and even poisonous snakes; but besides marmots, moles, rats, and leverets, its chief diet is mice, of which it requires 20 to 30 for one good meal. It usually perches on a hayrick, a post, or a dry tree to watch for its prey, sitting motionless save for a movement of its head from side to side, until a mouse emerges from its hole. Then it raises its wings, darts downwards, and secures the booty. In years when a superabundance of mice appear, the Buzzards also are numerous, and fare plenteously. At such times, hundreds of tufts of mouse-hair are found beneath the trees where the Buzzards spend the night.

It would be a good thing if the farmer were to set up perching posts in the places which are infested by mice, so that the Buzzards might settle on them to watch the ground. Posts about the height of a man, and the thickness of an arm, with a cross piece at the top, would perfectly serve the purpose.

The Buzzard, then, is useful; but it cannot be denied that it sometimes does harm when it gets into a pheasant run, or places where partridges and hares are preserved.

The bird is still common in Hungary. 


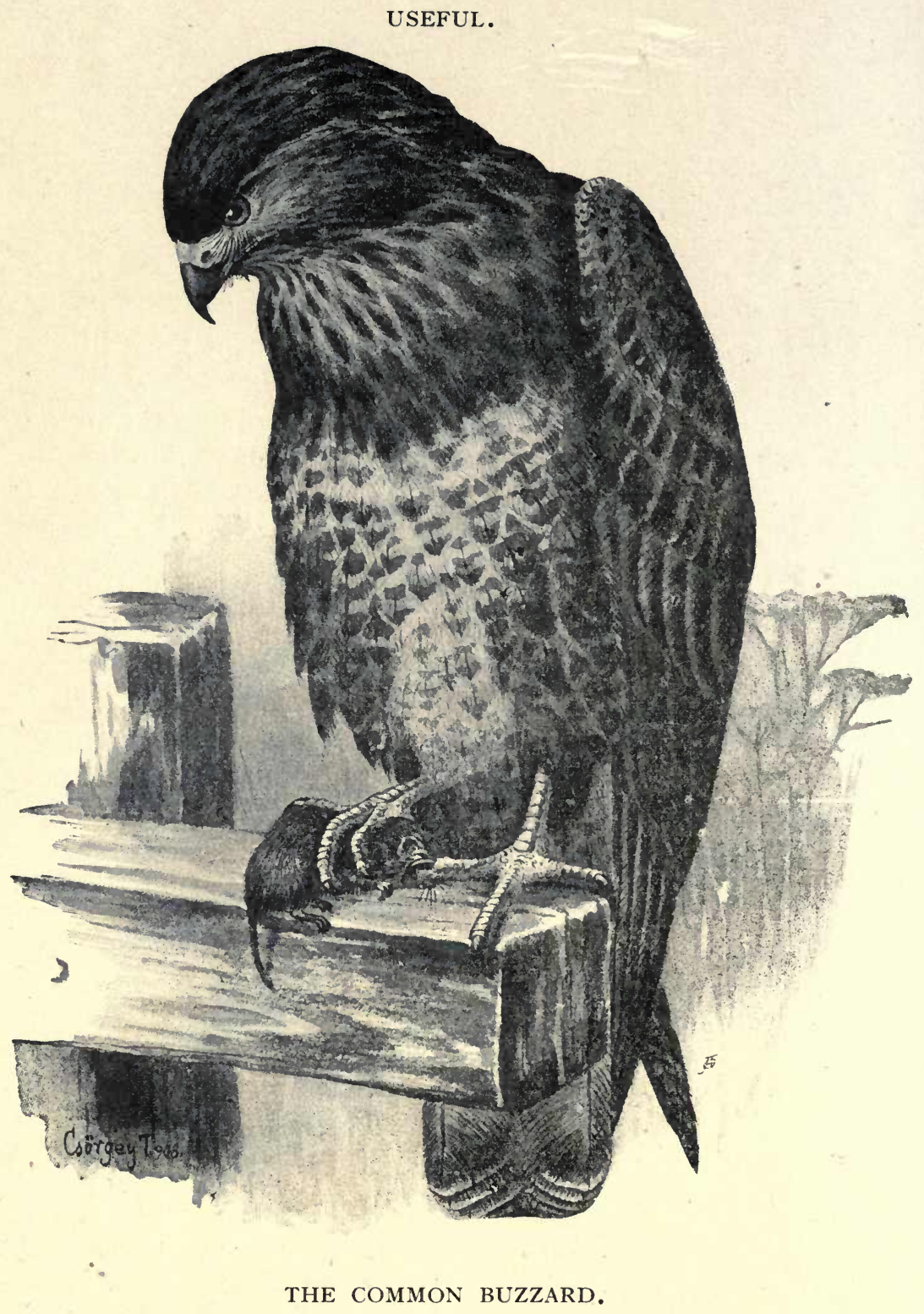


The Buzzard may still be seen circling high in the air in some of our own wilder wooded districts, uttering its mewing cry, especially in Wales, but it is fast decreasing. A correspondent from South Devon wrote me that it was not infrequently shot there. As Mr. Howard Saunders wrote, "It used to breed in Norfolk and other counties abounding with Partridges and ground game, without being considered incompatible with their well-being; but now that Pheasant worship has increased, the doom of that great devourer of field mice, moles, and other pests of the farmer which has never been proved to be destructive to Partridges and Pheasants is sealed. Still it might yet increase if fairly encouraged, and it is an interesting sight, either soaring over head or resting in its characteristic sluggish way on the branch of a tree. In the New Forest this used to be a common enough sight, but the bark strippers being at work just at the time of incubation, and knowing that they can easily obtain five shillings for a good well-marked specimen-the Buzzard has little chance now.

I find in my note book, "My glass shows a great brown and grey bird resting on a stumpy willow-what they call here a Mouse-Buzzard - that species so useful to the grazier, which we drive away by persecution. Presently it rises high to soar in fine circles over its hunting ground. The farmers encourage it because of its wonderful stowage capacity for voles, rats, and other small deer,-the game-preservers persecute it, because when pressed by hunger it takes old hen pheasants and even larger creatures. On our friend's estate here it is encouraged; the stomach of a dead Buzzard has been found to contain thirty mice. Also it is a deadly foe to 
the viper, although a bite from the latter has been death to the Buzzard occasionally. A Buzzard was once found dead on its nest with a viper lying under his body. The bird had carried it there to devour. This is a gentle looking creature, yet when hard pressed by hungermadly ravenous, it has been known to attack an ox. Humans are apt to become desperate under similar circumstances.

Said Butler in "Hudibras" :

"He'd prove a buzzard is no fowl, And that a lord may be an owl."

There is a good deal of variation observable in the colouring of the Buzzard, inclining sometimes to whitish, sometimes to brown or even to blackish. With its thickset body, this bird of prey exceeds the Raven in size. Its constant distinguishing marks are these: The cere at the base of the bill, and the legs, which are bare of feathers, are yellow; the nostrils are oval; the iris grey or brown. The shafts of the primaries and secondaries are white. The tail is crossed by seventeen dark bands, and appears fore-shortened. The bill is curved and hooked. The nest is built in the loftiest beeches and oaks. Three to four eggs form the clutch. They are rarely white, more often clouded with dirty-yellow on a lighter ground. 


\section{The Sparrow-hawk.}

\section{(Accipiter nisus.)}

Though the Sparrow-hawk, taken altogether, is a small bird, yet he is. a great thief, as may be gathered from his piercing eye. He is the terror of all birds of the Starling size, which he seizes while on the wing. Like a true robber, he watches for his booty in a secret kind of way; having selected one from among a company of flying birds, he flies below, among the furrows in the cornfield, along the hedges, and the border of the woods, and on to a haystack. When he has seen his destined prey he flutters sideways, rises into the air in circles, and when the little birds fly up he sinks somewhat lower; when at the proper height he claps his wings close to his body, and drops like a piece of lead on to the chosen, fluttering victim, seizes it by the neck in its flight, and strangles it with his sharp claws. He then flies slowly with it to a bush or a grassy-mound and devours it.

It winters in Hungary; it is not rare, but at the same time not very common. Its cry sounds like "Kirk, $k i r k$, kirk," or a rapid " $k i, k i, k i$," or a long drawn-out " kāk, kāk.,"

This bird was the sporting Hawk of our forefathers, and the people of the interior of Asia, and the Kurds, employ it for hunting at the present day. Wherever it goes it carries devastation in its train, especially among the domestic fowls. Its cry is loud and ptotracted. "Iwiā!" it repeats quickly on seizing its prey. When 


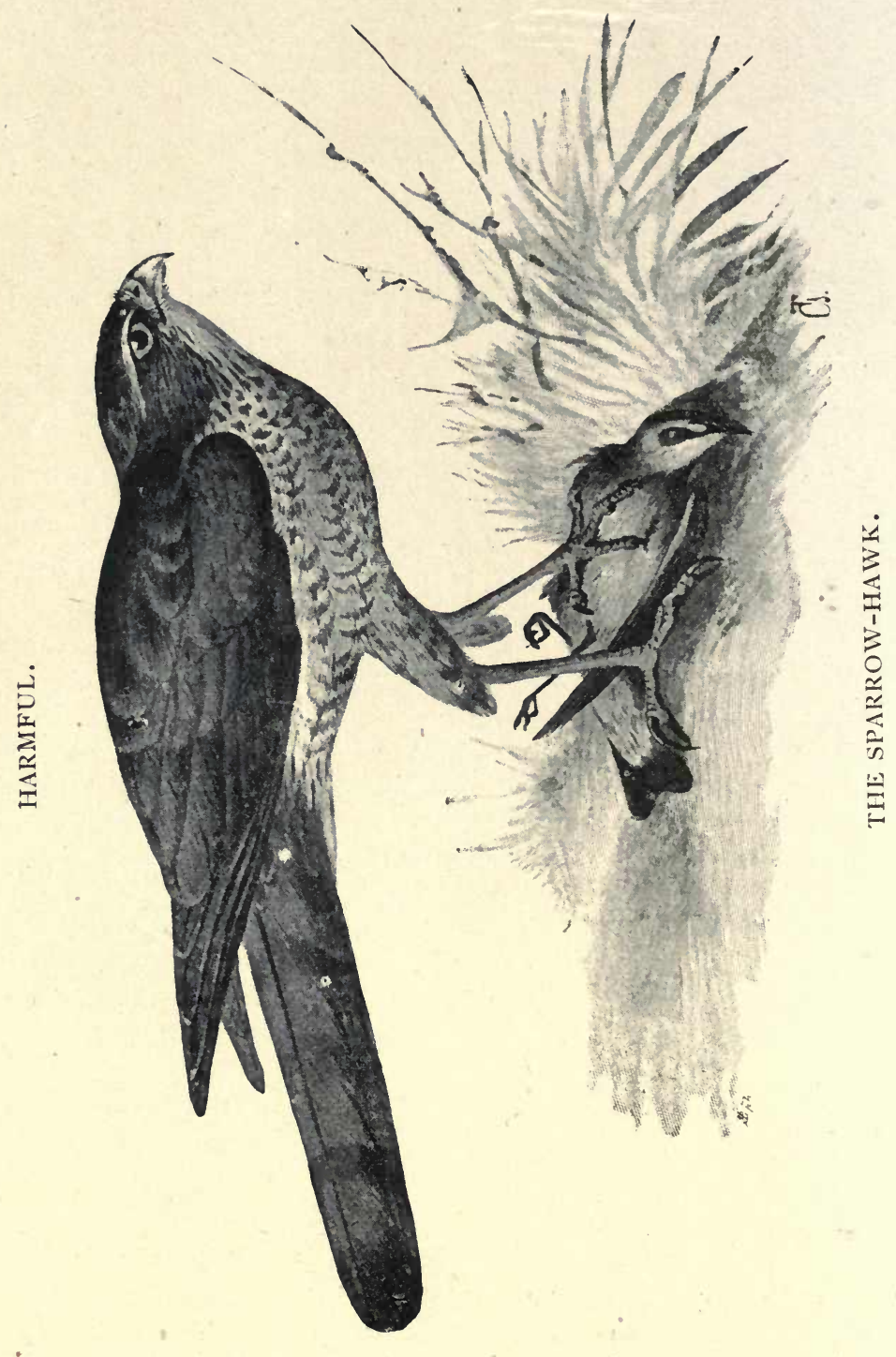


pairing the note is Gāck, gāck, gāck," and then more rapidly "Giā, giack, giack."

The Sparrow-hawk is well known all over Great Britain and also in Ireland, in all those districts which are well timbered. Its food consists for the most part of small birds, from the Thrush to the Wren. These are snapped up as the bird glides stealthily along the hedgerows or on the outskirts of some wood. In our own country it has been trained to take Partridges, Quails, etc. In India and Japan also it is used by the native falconers. It is a bold daring raider of our woods and fields. This bird has a history which reaches back into the far past. It received its latin name, Accipiter nisus, because of a myth relating to King Nisus of Megara, who, it is said, had one hair of red-gold colour, on the preservation of which depended the conservation of his kingdom. Scylla, the daughter of Nisus, being in love with Minos, King of Crete, son of Jupiter and Europa, treacherously cut the golden hair of her father -Nisus, and therefore he and his country were easily vanquished. The gods, angry with the unnatural daughter, changed her into a Lark, and Nisus into a Sparrow-hawk, under which form the unhappy father pursues his daughter unceasingly, in order to satisfy a thirst for vengeance. The ancients had all sorts of mysterious ideas, in connection with the Sparrow-hawk; they believed, for one thing, that he was the primogenitor of the Cuckoo. There is always something interesting in such old myths, in spite of their apparent absurdity.

Somerville, in "Field Sports," takes only the falconer's view of the Sparrow-hawk, when he says : 


\section{THE SPARROW-HAWK}

\section{"Enough for me}

To boast the gentle spar-hawk on my fist,

Or fly the partridge o'er the bristly field,

Retrieve the covey with my busy train,

Or with my soaring hobby, dare the lark."

The male Sparrow-hawk is about $\mathrm{I} 2$ inches long, the female often 15 inches. It has a long tail; its legs are slender, long and bare of feathers. The claws are sharp as needles. The toes are strong and the middle one is very long and slender. The bill is abruptly curved from the base, with a greenish-yellow cere. The plumage is bluish-grey above; while beneath, on the belly, it is crossed with wavy lines on a light ground. The tail has five dark ribbon-like bands across it. The Sparrow-hawk nests by preference in spruce plantations at a height of from I 2 to I 5 feet; it also makes use of deserted crows' nests. The clutch consists of four or five, occasionally six, and still more rarely seven eggs, chalky-white or greenish in colour, with drab-coloured spots.

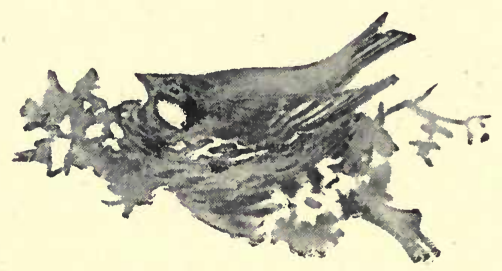

Too often a victim. 
The Goshawk.

(Astur palumbárius.)

THE Goshawk is bold in attack, and powerful in thrust. It is comparatively easy to tame, or at all events shows a certain tractability. Its aspect in cunning and cruel, and its claws must be carefully avoided. It is the terror of the poultry-yard and the dove-cote. When pursuing its prey nothing can divert its attention. It will even penetrate into the interior of a house. It will steal any warm-blooded animal that it can overcome, even an old hare. It seizes little Siskins, Goldfinches, Weasels, squirrels, and even mice. It lives in a constant state of warfare with the Crows. The latter birds fall upon it in flocks, pull and touzle it, when they catch it, but the Hawk usually carries the day. With a mighty thrust he seizes his prey from among the black mass, and gets away from his pursuers. It likes best districts where wood and field alternate, but it also settles in the neighbourhood of villages where it causes great damage among the poultry.

Next to the Lanner-falco lanarius - the Goshawk was the favourite among sportsmen in the olden days as indeed it still is among the nomadic tribes of Asia.

The Goshawk-Goosehawk-comes to Great Britain as an occasional visitor only, in autumn, winter, and now and again in the spring. There used to be some eyries in old fir-woods in the valley of the Spey a century ago, but in Scotland the Peregrine Falcon is called the Goshawk. In some old Scottish works on Falconry it is stated that the best Goshawks came from Ireland. 


\section{CHIEFLY HURTFUL.}

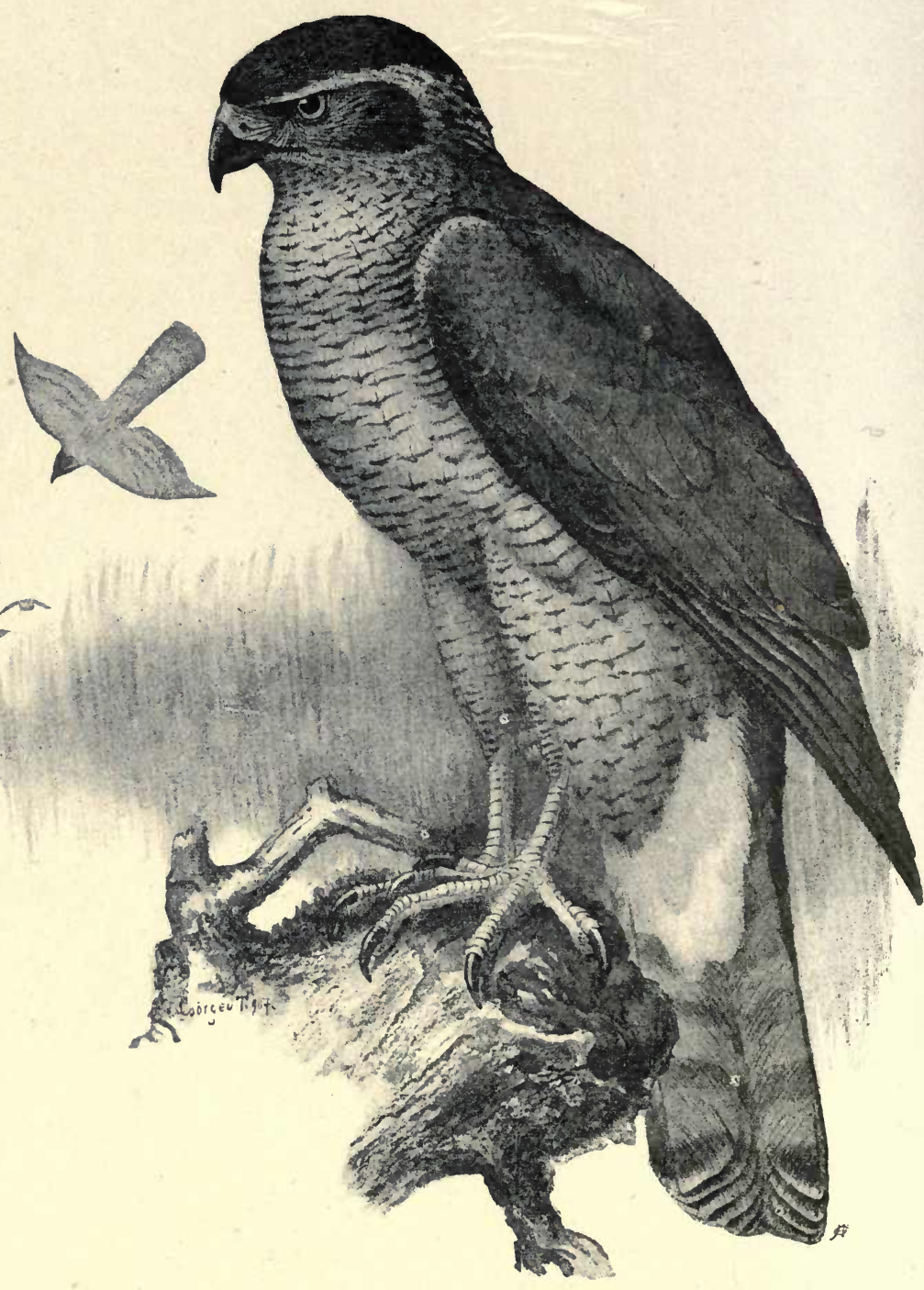

THE GOSHAWK. 
I know a place in Southern Germany, a sandy, raised piece of ground, in the middle of a wood, near the point of a peninsula, where only high fir-trees are; and there the bold Goshawk has his bulky nest which he uses year after year. On a clearing close to the Goshawk's nest there lie innumerable remains of Starlings and young hares. The Starlings fear him greatly; when he comes gliding low in pursuit of his quarry over the marshy ground beyond his wood, they keep close to the Crows, which are numerous on this peninsula. They feed with these birds whenever the Goshawk is in their neighbourhood, knowing that the Crows will attack him sturdily. During the skirmish with the Crows, the knowing Starlings make away from the scene.

The Goshawk punishes that bad but beautiful bird, the Jay, who does more harm here than the SparrowHawk and all the three species of Butcher-birds put together. The Sparrow-Hawk attacks the Jay also; but he only gets the better of him after a long struggle, whereas the Goshawk punishes quickly.

As I stood under the high fir-tree from which a pair of Goshawks took flight on my approach, one of the sudden thunderstorms common to the neighbourhood at this time of year broke overhead, and I had to shelter long, so that I had time to marvel at the great quantity of creatures these birds had taken to their family larder-hares, starlings, pigeons, ducks, and poultry of all sizes. The farmer here dreads it more than he does any other bird of prey, and we have no cause to regret its ceasing to build in our midst. A male and a female bird were: caught in a trap in the forest of Bowland, Lancashire, about the year I 835 ; now only an occasional bird is to be seen. 
A French writer says that the Goshawk is still used in Persia in hunting the gazelle, and that it is trained to feed on that creature's beautiful eyes by placing its food in the empty eye-sockets of a stuffed gazelle, so that when used in the hunt the Goshawk stops its victim by attacking and tearing out its eyes - a horribly cruel form of sport.

Keats writes :

"O Sorrow! why dost burrow

The lustrous passion from a falcon-eye?"

and Young :

"Pride, like hooded hawks in darkness soars

From blindness bold, and towering to the skies."

"Mark the gay squadron through the copse descending The greyhound with his silken leash contending Wreathed the lithe neck; and on the falconer's hand With restless perch and pinions broad depending, Each hooded goshawk kept her eager stand."

Burns says :

" Swift as a gos drives on a wheeling hare."

In the young bird the underpart is clay colour with narrow cross stripes and large longitudinal flecks. The iris golden-yellow; feet sulphur yellow. Claws strong and sharp. The adult has a narrow white line about the ear coverts and the eye; upper parts ash-brown; four broad dark bars on the tail; underparts white, thickly barred with ash-brown; cere, iris, and legs yellow. Length of the male 20 inches; of the female 23 inches.

The large nest of the Goshawk is composed of hard twigs. The eggs, usually four, are pale bluish-grey, - but later they become dirty greenish-yellow, and sometimes have a few rusty or olive markings. 


\section{The Новby. \\ (Falco subbuteo.) \\ Called in Germany the Tree Falcon.}

OF all the Hungarian falcons the Hobby has the swiftest flight; he even pursues the Swallow with success. All the small birds scream with terror when this bird appears. The Swallow dart in an agony of fear under their eaves; the Larks and other small birds press themselves down on the earth; the Quails and Partridges do the same. If a little bird happens to be in flight it tries with all its strength to soar higher and higher, so that the Falcon may remain beneath it, otherwise it is a lost bird. If the Falcon gets above, it shoots like an arrow, with closed wings, down on to the bird. The Hobby does not despise a grasshopper as food, in the twilight a moth does not come amiss; indeed it has lately been observed that it sometimes snaps at bees. But it does not eat carrion.

In the olden days the Hobby has also been used to hunt small birds.

At the present day it is a great friend to the railway, where it circles about the trains and drives away the small birds. It is by no means rare in Hungary.

In England the Hobby arrives about the latter part of May, and it may at intervals be found breeding in most of the Southern counties, notably in Hampshire. Once it nested in Essex pretty regularly, also to a certain extent in Suffolk and Cambridgeshire, Lincolnshire and Norfolk, rarely in Yorkshire, sometimes in the Midlands, but in the West and in Wales it is scarce. It has never been known to nest in Scotland, and very few Hobbies have been seen in Ireland. 
HARMFUL.

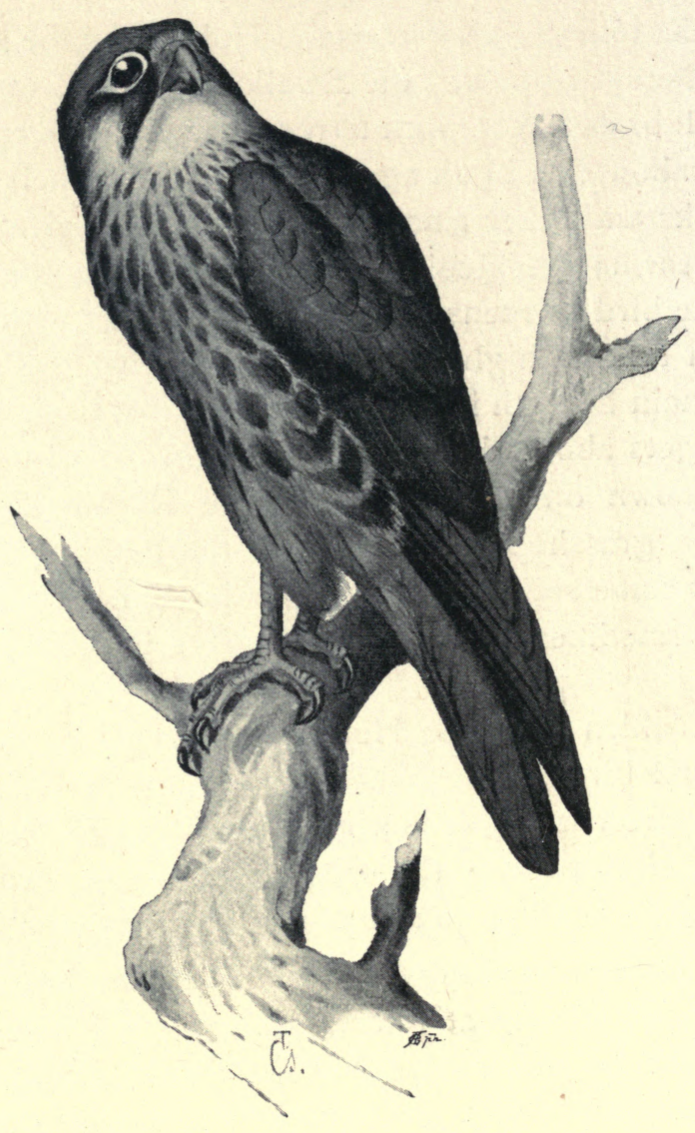

THE HOBBY. 
It will follow the sportsman and seize a Quail in front of him, according to the late Howard Saunders, but Lord Lilford demurred to this, and said a Hobby will wait on over ranging dogs, on the chance of a young or moulting Skylark, but never attack game birds, as it could not hold them. It is a terror to Larks as well as Swallows, but it does some good in reducing the numbers of cockchafers and dragonflies, which are favourite articles of its diet, with other small insects.

In our country it never makes a nest for itself, but it takes possession of one that has been built by a Crow, Magpie or other bird, in a tree. The female has a curious habit of brooding on an empty nest or upon eggs of the Kestrel before she lays her own. In autumn it leaves the woodlands to take to the open country.

Cowley wrote :

"Like larks when they the tyrant hobby spy, Some wonderstrook, stand fix'd, some fly."

And Dryden :

"Larks lie dar'd to shun the hobbies' flight."

The Hobby is as big as a small pigeon, but has a slenderer body. The tip of the wing reaches to the end of the tail or even beyond it. Legs and cere are yellow. The eyes are dark brown, with a keen expression. The serrated bill is yellowish at its base, but black at the tip, which is strongly curved. The back is slate-coloured, while breast and belly are marked with black longitudinal stripes on a light ground. The Hobby builds its nest in the tops of high trees in small woods. The eggs number three or four, and are marked with thick rusty-brown spots and streaks on a ground-colour of pale buff. 
USEFUL.

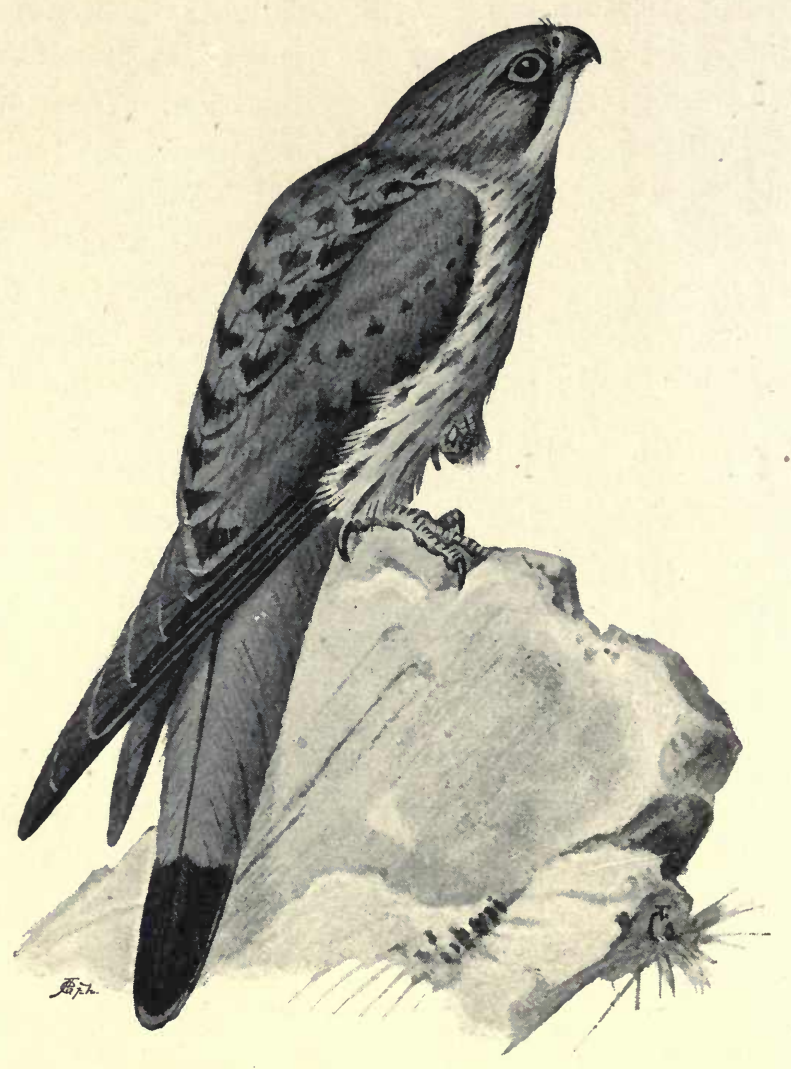

THE KESTREL. 
The Kestrel.

(Falco tinnúnculus.)

THE Kestrel also has a beautiful flight; but it is not able to catch small birds when on the wing. It is a master in the art of remaining in one spot in the air, with a very slight apparent motion of the wings. It stops suddenly in its flight at about the height of an ordinary church tower, bends its spread tail stiffly downwards and beats rapidly with its wings. It often poises itself in this way over meadows, cornfields and moorlands, and marks with its brown, sharp eyes any mouse or marmot that slips out of its hole. Sometimes it finds a brood of young birds, and these it does not spare. Crickets, grasshoppers and lizards also fall a prey to this hunter, but mice form its chief diet, and for this reason the bird is useful. When it has caught sight of its prey from a height in the air it suddenly closes its wings and drops, but when quite near the ground it spreads them again, and thus picks up its victim. It eats the smaller insects out of its claws while flying; but larger prey it carries to a quiet spot. Its twittering cry is often heard; it sounds like “ Klee, klee, klee." It leaves Hungary in severe winters. The Kestrel is the most numerous of the birds of prey in that country, where it is quite at home, even in the rush and noise of towns.

The Kestrel is commonly known as the Wind-hover, on account of its habit of hanging motionless in the air against the wind. It has a very graceful flight. This Falcon is quite the commonest of the British birds of prey, and we should have still more of these useful 
Falcons in our country were it not for the prejudice and ignorant ideas of so many of our gamekeepers and farmers. In Scotland the former are becoming much more aware of the harmlessness and the usefulness of the Kestrel. Considering the fact that the creatures forming its principal food are mice, it is strange that our agriculturalists have not valued its services sooner. The gracefulness of its flight makes it an interesting point in a landscape. It is as well known to country children in our Southern counties as is the Cuckoo. If their nest is robbed before the full number of eggs is laid the pair will remove such eggs as are left to the next suitable empty nest they can find and proceed with their family duties there. The Kestrel is a pleasanter bird to keep as a pet than others of his family; it is easily tamed, and afterwards can be kept at liberty, as it will come to call or whistle if it is fed regularly at the same time and place. The late Lord Lilford, who knew more practically about Falcons than most ornithologists said : " I cannot altogether acquit the Kestrel of an occasional bit of poaching; a small Partridge or Pheasant astray in the grass is no doubt too tempting a morsel to be resisted, but any petty larceny of this sort may well be condoned on account of the great number of field-mice and voles destroyed by these birds." In Spain its food consists chiefly of beetles.

A great many of our Kestrels leave us at the approach of winter when the food they like best is too hard to find.

The Kestrel is about the same size as the Hobby, but is a slenderer bird, and its tail is longer. The tail is of a beautiful grey colour and extends far beyond the tips of the wings. Near its extremity it is adorned with 
a broad, dark, transverse bar; the tip itself, however, is white. The back is reddish with dark, triangular markings; the flanks light-coloured with black longitudinal marks. The bill is curved from the base, and is short and strongly hooked. Cere and feet are yellow. The tail of the female has several narrow transverse bars, with tip as in the male. For nesting places the Kestrel chooses by preference ruins, towers, and lofty crags, very seldom selecting a site in a tree. It lays four or five eggs, rarely more than six. They are thickly spotted and splashed with brownish-red on a light ground.

The Merlin or Stone-hawk (Falco cesalon) is the smallest bird of our British Falcons. It breeds regularly on our moorlands, not in such numbers in the South as beyond Derbyshire. In many parts of Wales too it nests. It is fairly common too in the mountainous parts of Ireland. In the autumn the dashing little fellow comes down to the coast and bays where he can prey on Dunlins, Snipe and other waders. He has high courage and will kill birds you would not think him capable of mastering. The Merlin will kill the Skylark if pinched by hunger, but both he and the Hobby prefer birds of the Finch family. 
HARMFUL.

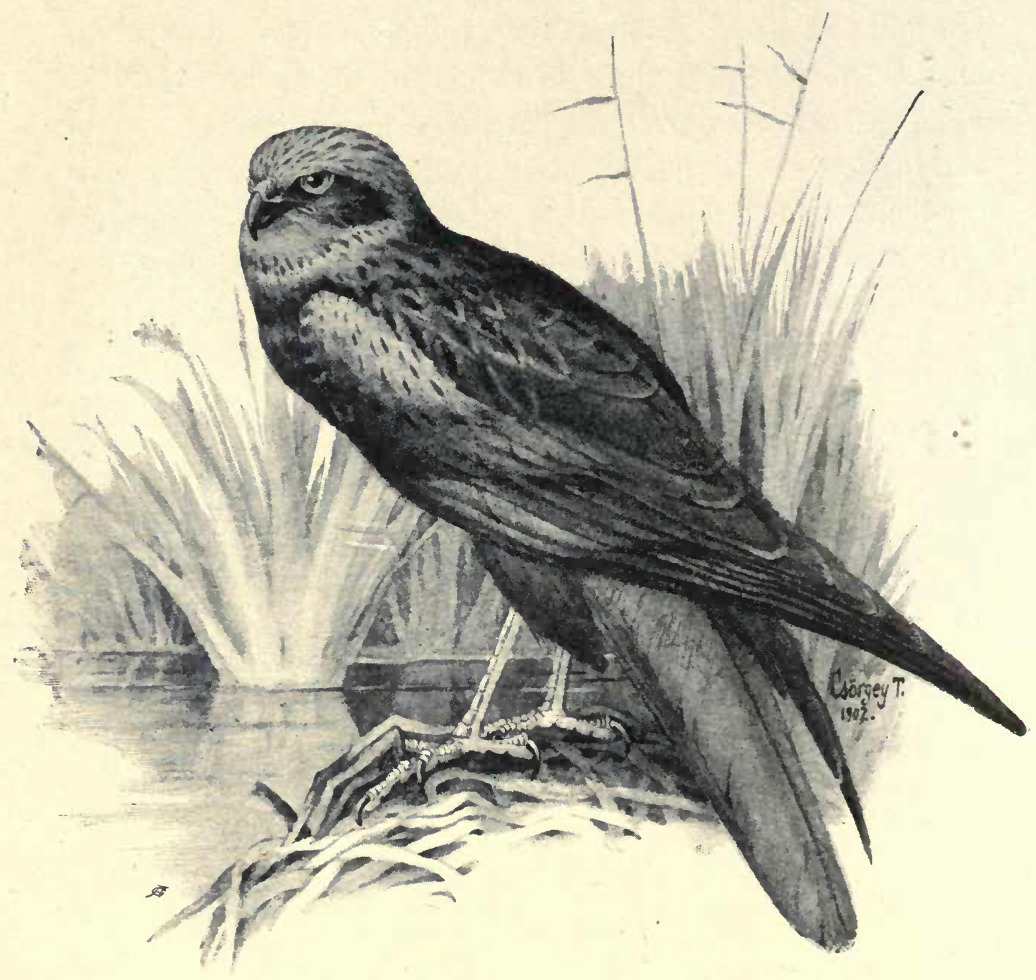

THE MARSH-HARRIER. 
The Marsh-Harrier.

(Circus œruginosus.)

(Formerly known as the Moor-Buzzard.)

THE Marsh-Harrier is one of the shyest and most cunning of our birds of prey. It immediately attracts attention by its size and its constant activity; but it requires a good sportsman to get a shot at it. It is most easily got at when feasting among the high grass at the edge of the reedy marsh; it then forgets to be prudent and sometimes takes flight only too late. Early and late it hovers over the borders of the marshes and reed-beds, sweeping, circling without rest, now and then making a swift descent into the rushes and the sedges and securing its prey. There is no small creature of the marsh, the bog, the heath, or the moor that this bird will not take; it works special destruction among the singing birds which nest among the reeds and sedges. It does not wait for the young birds to be hatched, but is very clever in breaking open the eggs and devouring the contents, always bringing them on to dry land for the purpose.

The birds of the reed-land know this raider well, and as soon as the first flap of his wing is heard the terrified Lapwings, Gulls, Terns, and others, arise with loud cries and attack him tooth and nail. When brooding it lives almost exclusively by egg stealing; later on the moor hens afford provender for this insatiable thief. It leaves Hungary for the winter, but returns in early spring. Its cry varies. In spring it is " kei, kei," in autumn it is like that of the Jay. The female utters a loud "pitz! pitz."

This bird is common in the Hungarian marshes. 
The drainage of our Eastern fens and the reclaiming of marshland in Yorkshire, Lancashire, Shropshire, Dorset, Somerset, and some other counties once frequented by this bird has caused it to become scarce where formerly it used to breed freely. Sometimes a pair having wandered over from Holland will try to rear a brood in our Norfolk Broads district, but the sportsman-sic-and the collector will not allow them to succeed. In Ireland the bird was formerly common enough about Lough Erne, along the Shannon valley, in Co. Cork, and other districts, but during the last fifty years the gamekeepers have nearly exterminated it by poison. It is known to be a great destroyer of the eggs and young of Waterfowl, but during most of the year it feeds on small mammals, frogs, and reptiles as well as birds.

This is the Duck-Hawk of the marshmen. When the sun is glinting through the mist he may be seen gliding hither and thither, low down over the grey-green flats. At noon he is high up in the clear blue sky. The tender young ducks - called "flappers" are his favourite diet.

Jean Ingelow, in "The Four Bridges," says :

"The bold Marsh-Harrier wets her tawny breast-

We scared her oft in childhood from her prey."

The Marsh-Harrier is smaller and noticeably slimmer in build than the Buzzard. The tail is long, the legs are long, thin, and bare of feathers, and the claws sharp. The head has something about it that suggests an Owl, for the facial disk is conspicuous and the eyes glance forwards as well as to the side. The bird's plumage is brown, very dark in places: but the head is lightcoloured, being whitish in males and yellowish in females. Inhabiting reed-beds, the bird builds its nest anong reed-stems or bulrushes. The eggs, five or less frequently six in number, are greenish-white in colour. 
The Hen-Harrier.

(Circus cyaneus.)

THE nest of the Hen-Harrier is built of roots and plant stems, is soft within and is often placed on the ground; if in heather, or dried up marsh, it is often a foot high. From four to six bluish-white eggs, sometimes yellowishbrown or rufous markings, are laid.

This bird of prey has a light, sweeping flight. It leaves Hungary in winter. It hunts alone and takes its food exclusively from the ground. This consists of small mammals, especially mice, the bird is also particularly fond of robbing the nests of such birds as build on the ground; it sucks the eggs and devours the small downy creatures within them. It also takes the little hares-in short, it is one of the most destructive birds in the fields which it frequents and hunts over untiringly. On the other hand, there comes a time when the number of field mice has increased beyond measure. Then the Hen-Harrier joins the other birds of prey and destroys enormous numbers of those enemies of the farmer. For this reason the species should not be altogether exterminated.

Of late years the numbers of the Hen-Harrier have been greatly thinned by game-preservers, and it only nests now on a few of our largest and wildest moorlands and wastes. Even in Scotland it is fast decreasing so far as nesting goes, whereas it was once plentiful there. Still there are a fairly large number of young birds in the autumn, and then, too, the adult birds come down from the higher-lying districts to the lowlands. It used 
HARMFUL.

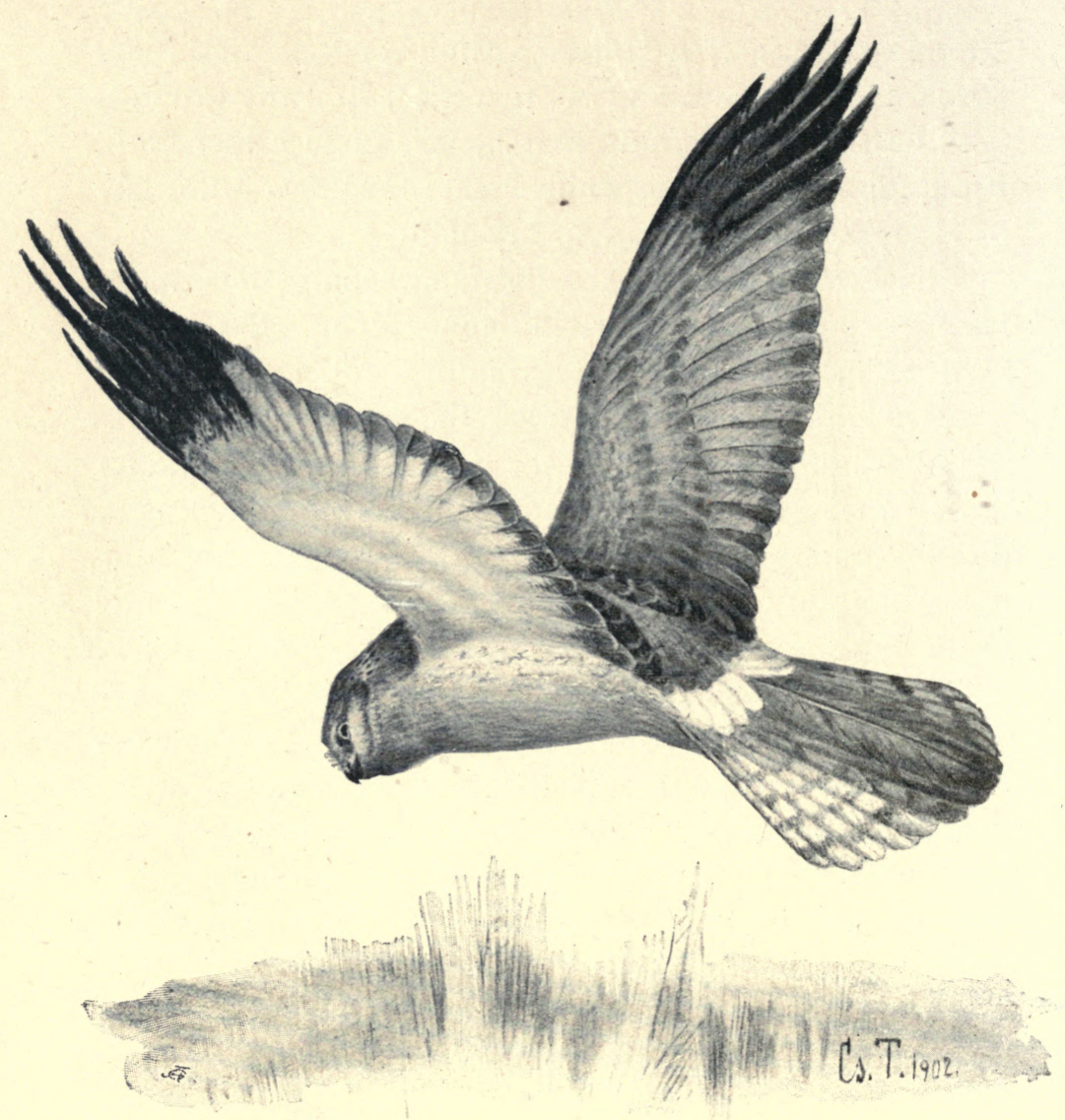

THE HEN-HARRIER. 
to breed in the Fen-lands of East Anglia until the reclaiming of marsh lands drove it away. As to this I may be allowed to quote again here from an old ballad written before the fens were drained, it gives the feeling of the fen-dwellers of that day.

"Come brethren of the water, and let us all assemble, To treat upon this matter which makes us quake and tremble;

For we shall rue it, if it be true that fens be undertaken, And where we feed on fen and reed, they'll feed both beef and bacon.

The feathered fowl have wings, to fly to other nations, But we have no such things to help our transportation; We must give place-oh, grievous case-to hornéd beast and cattle,

Except that we can all agree to drive them out to battle."

"As a gamekeeper once said to me," says "A Son of the Marshes,' “The sooner them big 'uns is gone or done for the better; there's nothin' but a chow-row from morning to night. Our head 'un says they must be knocked over, and the guv'nor he's got the same tale. They can't git at 'em no more than we. It ain't so much what they ketches, tho' they tries hard at it, as what they frightens off the fields; it spiles the shootin'. Them 'ere damned great things hovers an' swishes after the birds till at last the coveys makes for the hedgerows an' you has to git 'em out as if you was beatin' for cocks. 'We ain't had none o' them 'ere blue an' ring-tailed hawks - harriers-'bout here lately. 
They're reg'lar wussers ; they kills 'em dead at one clip, an' takes 'em out in the middle o' them big fields to eat 'em. They ain't goin' to let you get near 'em, not they, an' they wun't fly over a place where you kin hide. I've tried to git at 'em, but it all cum to nothin'. Them 'ere blue hawks an' ring-tails would circumvent the devil."’

The adult male has the upper parts a slatey-grey tone of colour, the rump white, throat and breast bluish-grey - under parts white. The female is brown above, the neck rufous-brown streaked with white-there is a distinct facial ruff, giving the head an owl-like appearance, suggesting that this species might be the link between Owls and Hawks - tail brown, having five darker bars, hence the old name of Ring-tail given to the female of this bird; under parts buff-brown with darker stripes. Length 2 I inches. The young resemble the female. 


\section{CHAPTER IX. \\ Rational Bird Protection.}

ONLY a savage, or an ignorant man, can harm or wish to get rid of a bird before he has convinced himself that it is harmful. I have said already that in the abstract there are no useful and harmful birds, as such. The bird exists as a product of Nature, to fulfil, like everything else, the tasks allotted to it by Nature and in Nature, which no other creature can perform.

It is man who makes the bird useful or hurtful to himself, when he tears up the turf, and sows such seed as brings rich crops which serve the bird for food; or when he plants an orchard or vineyard, where there was none before. Therefore, for the good of the birds-and also of man-we must carefully reflect what it is our duty to do and how we can best do it.

The Tits, Hedge Sparrows, Flycatchers and others whose industry know no rest, do invaluable service to a sensible man; for while the most observant and diligent gardener can only destroy those caterpillars' nests which meet his eye wholesale, these useful birds, hopping about, darting and leaping, hanging and pecking, devour all the mischievous pests, even when they are quite out of reach of man, and certainly out of his sight.

These services can even be estimated to a certain extent.

The tiny Wren consumes in one year more than three million insects in different forms, either as eggs, 
chrysalis or perfect insects, which, if they were allowed to propagate would result in countless numbers.

The Blue Tit, not much larger, destroys six and a half million insects in one year. If it bring up a family of 2 to 16 young ones, it means that one family of Tits puts about twenty-four million destructive insects out of the power of doing harm. Whoever, therefore, either from cruelty or ignorance, catches or kills these useful little birds does a great injury to the common weal.
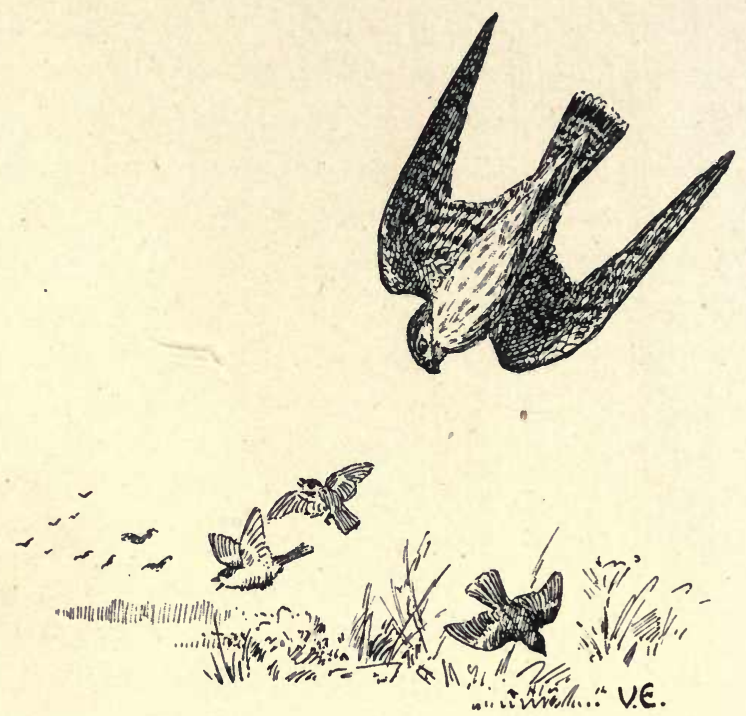

THE RAIDING HAWK.

The insect world has great power everywhere, and where birds and other insect-eating creatures are destroyed through ignorance there follows the destruction resulting from the ascendancy of these pests which appear, not in tens of thousands, but in millions. Twenty-one years ago any person who had ventured on such an assertion would have been laughed at, but 
it is now a well-known fact that some of the most renowned vineyards have been entirely ruined by the Phylloxera, an insect which can scarcely be seen by the naked eye.

In former times, when a great deal of uncultivated land covered the plain, in its natural state, the air rang with the song of birds. Woods, meadows, thickets and pools were thronged with the feathered songsters. In the course of time, however, things have greatly changed; in many districts the woods are thinned or grubbed up, the plough has torn up the meadows; every little scrap of thicket has been hewn down; whole forests are being cut down by degrees to supply the paper mills; and so the birds are losing their nesting places, and death and destruction lurk in waiting for them on their migrations. Devastating storms which overtake the immigrant flocks often destroy the feathered wanderers in great numbers. This, however, is the course of Nature, against which we are impotent.

After all the birds' worst enemy is man, with his ignorance, or, still worse, his cupidity: He has plundered the nest and destroyed the brood; he grudges every grain of corn which the bird has richly deserved by its work throughout the year.

Steamers and railroads make it possible for birds, which are caught by millions, to be sent alive into the great cities as delicacies of the table. So, from year to year, they are becoming rarer.

So much the more are we bound,-for the good of heart and soul, as well as for the blessing of the land and its workers - to protect the useful birds as much as we conscientiously can so that they may increase in numbers. 
Once, while on a journey to the Northern Ocean, I travelled the whole length of Denmark. Moor, bog and sandhills cover great stretches of land. Coarse heath grows over the sandhills. Poverty-stricken huts are scattered here and there in these districts, the tenants of which live by turf cutting. There is neither wood nor coal, so that the dried bog furnishes the sole fuel. A small spotted cow is usually seen tethered with a long rope near the cottage. This animal provides milk for the household. In front of the dwelling, at a distance of about fifteen paces, a pole, from i3 to 20 feet in height, is set up, at the top of which is fastened a nest-box for birds, and this is usually inhabited by Starlings.

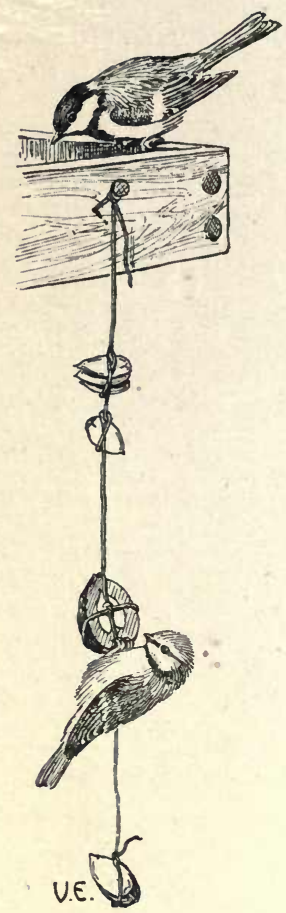

It was a pleasant sight, towards evening, that of the weary turf-cutter, sitting on the little bench before his cottage, smoking his pipe, bending down to talk to his child, and then, with heartfelt pleasure, setting himself to watch the pair of Starlings chattering on the nest-box, and enjoying life generally. In many districts nestboxes are fixed on fruit trees in gardens and in every other suitable place, and in these dwell all the best and most industrious workers-Tits, Flycatchers, Redstarts and others.

There is a proverb which may be translated as follows : " Take nest and eggs from brooding bird-no fruit is found, no song is heard." Also in the Bible we read: 
"If a bird's nest chance to be before thee in the way, in any tree or on the ground, whether they be young ones or eggs, and the dam sitting upon the young or upon the eggs, thou shalt not take the dam with the young."

We must guard the nests from evilly disposed men and from roving predatory animals as much as lies in our power. But the real problem is this: The landowner uproots bushes, fells old trees, prevents the nest building of our most useful birds and cannot give back to them what they have lost. He prevents the possibility of their collecting again and increasing, and consequently from performing their useful duties, which are continually increasing. Where, however, bushes and trees have been rooted up, new ones may be planted, and the birds encouraged to return, although we cannot replace them at once-for hundreds of years may pass before the trees grow tall enough, and we cannot wait so long. Then we try to do by artificial means what we cannot do by nature; and we must be careful to study nature in our operations or we shall not succeed.

The Woodpecker, which lives in hollow trees, shows us how to build an artificial nest.

Table V., Fig. I, gives a section of the nesting-hole of a Woodpecker built by himself.

Fig. 2 is a perfectly designed nest for Titmice.

Fig. 3 shows the same nesting-box complete, provided with entrance hole and cover.

Fig. 4 shows an open nest-box for Flycatchers and a black Redstart.

The most important is that shown in 2 and 3 as it is specially arranged to suit Titmice. 
I

2
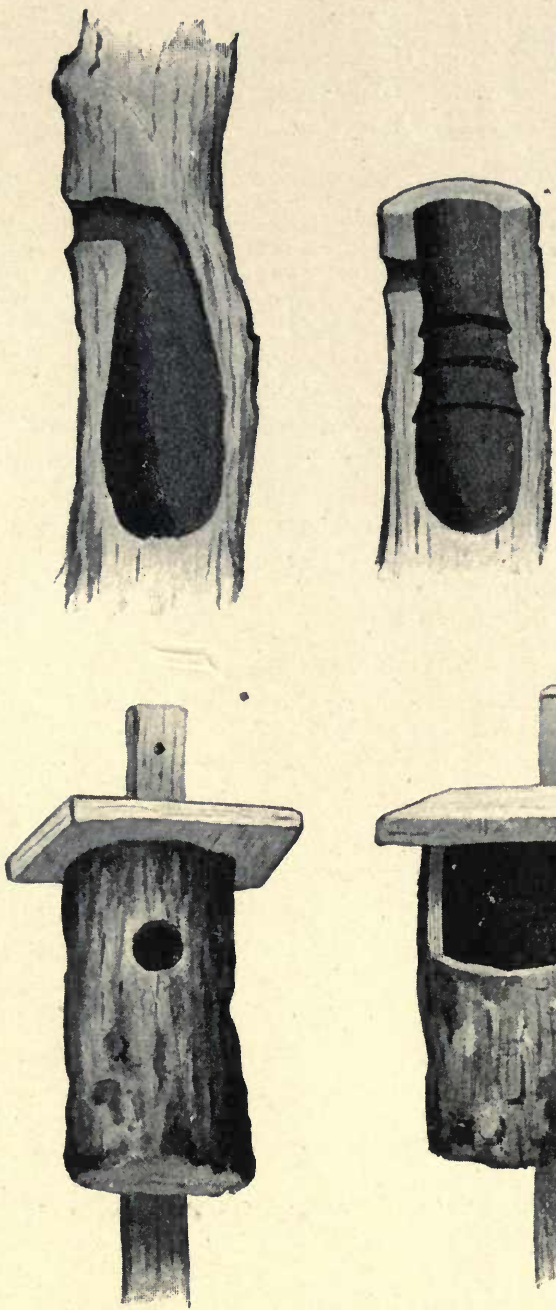

3

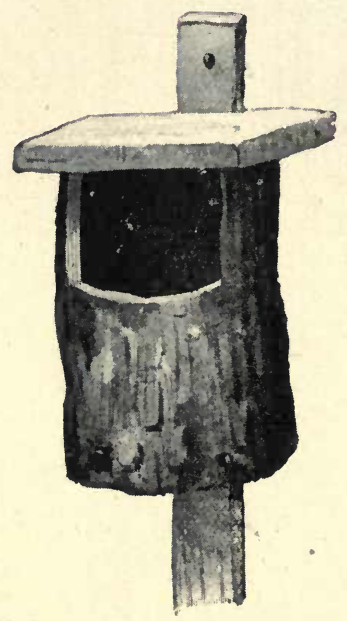

4 
Nest-boxes, and especially their holes, should, of course, be of different sizes, according to the birds that are to inhabit them. The opening is always round, and is of varying size according to the species. Many directions as to these are given in a paper by Baron von Berlepsch, "On the Protection of Birds Generally," published by the German Association for the Protection of the Bird World, and also by publications of the Royal Society for the Protection of Birds in Hanover Square, London.

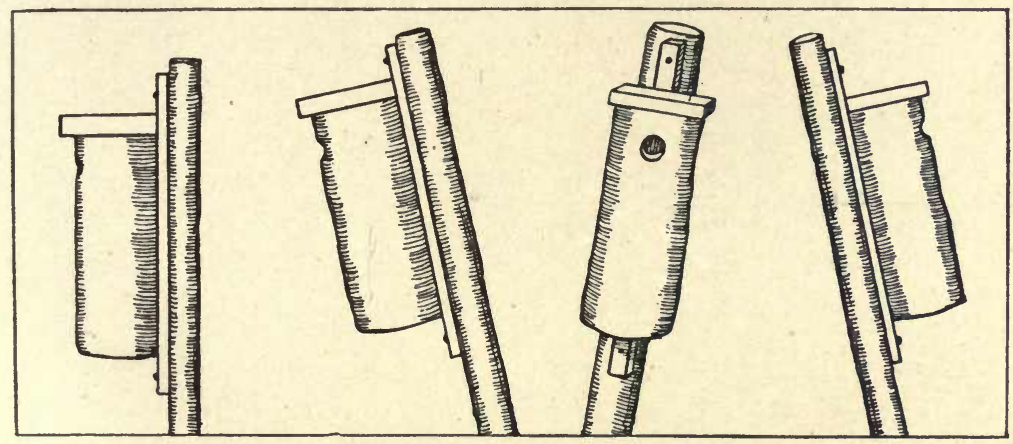

Nesting Boxes on Poles.

The following are some approximate measurements for nest-boxes :-

For Titmice :

height, I I $\frac{1}{2}$ inches ;

depth from back to front, $4 \frac{1}{2}$ inches ;

diameter of round opening, $I \frac{1}{4}$ inches.

For birds of the size of a Starling :

height, I $8 \frac{1}{2}$ inches ;

depth back to front, 9 inches;

diameter of opening, $\mathrm{r} \frac{3}{4}$ inches. 
For Green Woodpeckers :

height, I $9 \frac{3}{4}$ inches;
depth back to front, 9 inches;
diameter of opening, $2 \frac{3}{8}$ inches.

The measurements for the Wild Pigeon are the same as these last, except for the opening, which should be about $4 \frac{1}{2}$ inches wide.

Flycatchers and Wagtails require a box as shown in Fig. 4. This is 9 inches high, and has an opening about 4 inches square.

The edge of the entrance to a nesting-box should be rounded off, as in the hole of a tree, to make it more natural to the bird's feet.

The nesting-boxes should be fixed in orchards, gardens, and houses on the edge of a forest, on the trunks of trees and branches, also on poles, and fastened by means of strong flexible wire, or, still better, by screw-nails. They should be placed perpendicularly, slightly inclined or crooked, but never inclined backwards as the rain gets in and the Titmouse has sense enough to avoid such a nesting-box. They should be fixed a little lower than the average height of a man, and so arranged that the morning sun strikes the entrance hole if possible. The box is an exact copy of the nesthole of the small spotted Woodpecker, and experience teaches us that the unoccupied nest-holes are frequently used by the Titmouse. In spring the Titmice not only fight among themselves for the possession of these nestholes, but also with the hosts of House Sparrows which strive to rob them of the holes. These Sparrows come in crowds and make a great noise in the place. Being of a powerful build, and provided with sharp beaks, the birds 
finally oust the Titmice. To contravene the House Sparrow we must hang the nest-box somewhat low, about one yard from the ground. The careful and suspicious bird dares not trust himself in it. The Tree Sparrow, which does not come too near the haunts of man, but hovers on the fringe of the villages or street gardens, bushes and heaths, is a trusting bird, and not very heavy. It likes nest-holes immensely, and attacks those which are placed low; driving the Titmouse out.

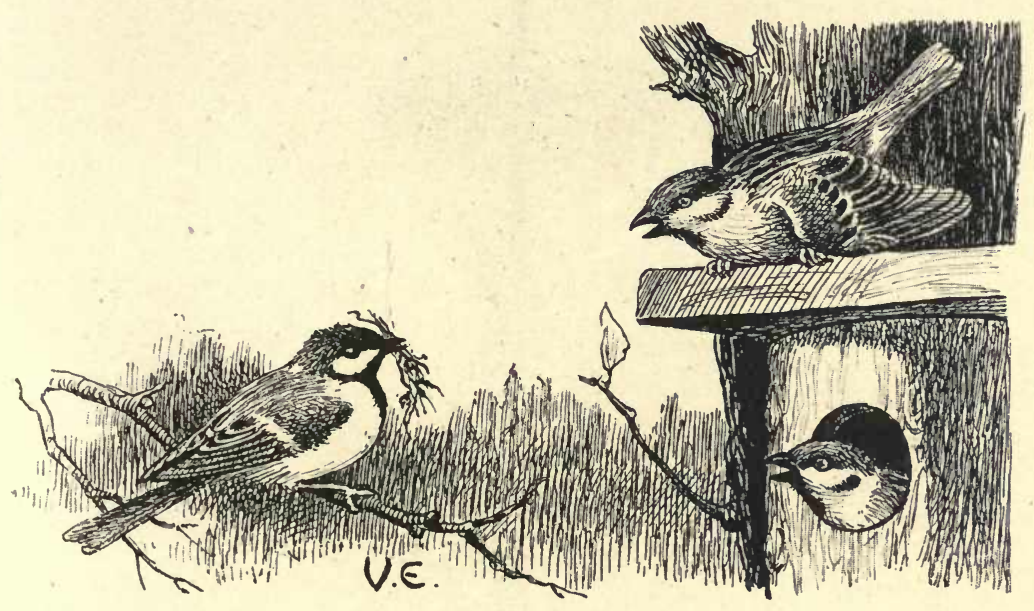

SPARROWS HAVE OUSTED THE TITMOUSE.

The Hedge Sparrow, again, lives on insects, but he is not clean, and is no friend of the garden; therefore, when we find him fighting with the Titmouse for possession of the nest-holes, we help to oust the Hedge Sparrow in the interests of the garden and the wood.

The following birds must be protected at nesting-time : The Great Titmouse, the Blue Titmouse, the Coal 


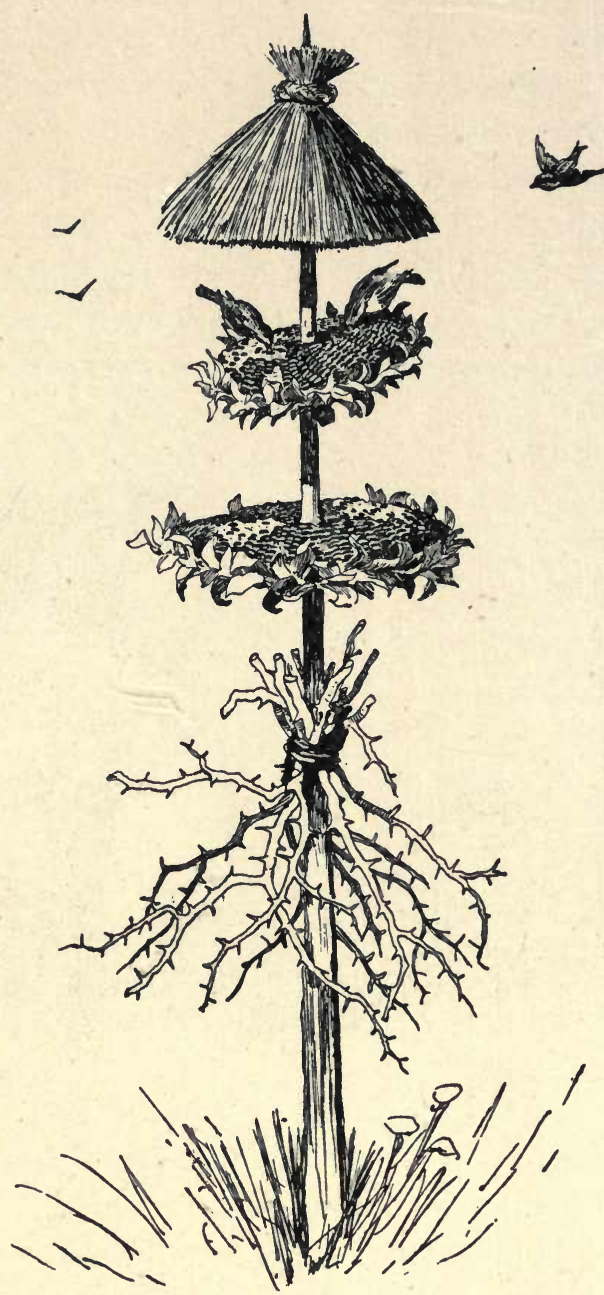

A PLEASANT MEAL ON THE SEEDS OF THE SUNFLOWER : THORNS BELOW TO KEEP THE CAT AWAY. 
Titmouse, the Marsh Titmouse, and Crested Titmouse, because all these birds are likely nesting-box dwellers. The method organised by Baron von Berlepsch, and used in Hungary by Minister Darányi, with slight alterations, is intended to bring the vanishing singing birds back again. By the use of different sized nestboxes it is possible to collect different kinds of birds. I know by experience that by arranging the bushes in close, twisted branches we can get the useful and singing Whitethroats to build their nests.

The importance of a rational study of this question of the protection of birds, with particular regard to their economic significance in given districts, has been demonstrated in Southern Victoria in a remarkable manner, where great mistakes have been made by settlers who seem to have been desirous of encouraging our own British birds about their homesteads. To take steps which resulted in the nesting of a colony of Fieldfares in a district where they had so far been unknown to breed, as Baron von Berlepsch did, was most advantageous, since the Fieldfares drove the murderous Shrike from the field. Again, by fixing up artificial nesting-boxes, made according to this great naturalist's pattern-on stakes placed in certain districts of North Germany, ninety per cent. of these became inhabited by Titmice, until that time strangers to the region, where, however, their services were most desirable.

On the other hand, Greenfinches, which were introduced into Southern Victoria by Australian settlers twenty-five years ago, took possession of the pine trees, which were the only trees that afforded enough shade and cover, and were the nearest approach there to their usual nesting- 


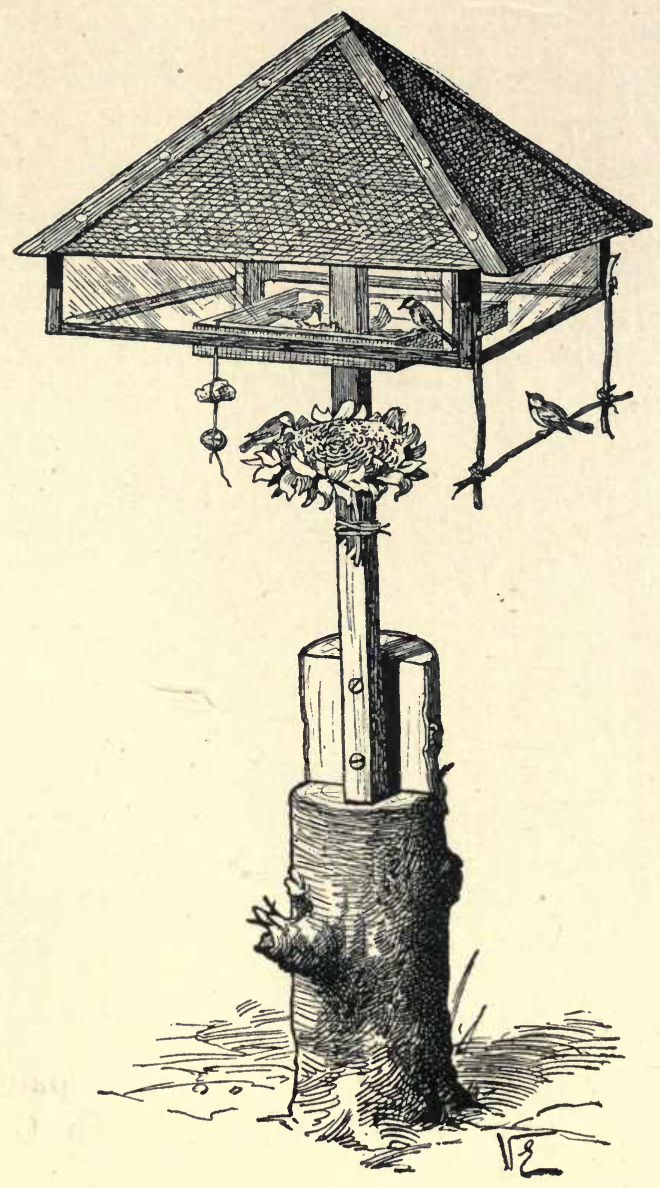

A FEEDING-PLACE FOR WET WEATHER.

As a rule only feed the birds when weather reasons prevent them procuring their own food. 
places; and they drove away from the district the useful little native Tits, which feed among these trees and have their own appointed work on them. A correspondent of 'a Geelong paper writes again of the charming sight of a number of English Blackbirds hopping about on a lawn beneath the spraying water-hose, and busily feeding on the worms. Yet this same bird is becoming a great nuisance to the fruit growers there. This is also the case in New Zealand, where large prices are now being offered for dead Blackbirds and their eggs. The Starling, again, which is so useful in our own pasture lands, has been known to clear out a vineyard in Southern Victoria in a single night. Thrushes are looked upon there as suspects, but opinions are divided as to this bird.

We have already written about the Quails, imported into the canefields of Hawaii, to be in their turn exterminated by the mongoose, who had been brought there to eat up the devastating rats.

To sum up the whole matter, interference with the balance of Nature must only be undertaken with knowledge and discretion; and those who undertake it must study, and profit by the recorded experiences of our accredited guides in this direction. 


\section{IN CONCLUSION.}

THE scope and limits of the present work does not allow of the inclusion of some of the chapters contained in the latest Hungarian edition, such as those treating of the skeleton, the viscera, etc., nor can this be taken as adequately representing the work of the Royal Hungarian Central Bureau of Ornithology of which Mr. Herman is the Director. That work is arranged on a regular scientific basis, and it includes that important investigation with regard to the food of birds, which is carried on by a fully qualified entomologist. The Bureau has its collection, which contains dried ingluvies, i.e., contents of the stomachs of nearly 9,00o different species of birds; skeletons, skins, eggs, nests and insects.

The Bureau has its meteorologist, its biologist, 267 corresponding professional ornithologists, and as many as 326 foresters contributing the results of their observations and experiences, besides a large number of foreign correspondents. There is a huge collection of data for the members of the regular staff to work from. These are written on separate slips, on each of which is the name of the collector, his point of observation, the character of the district in which this is carried on, the scientific name of the species, and the date of observation. The migration of birds is also made the subject of systematic observation.

An important publication, "Aquila," serve well in keeping together these different workers in connection with the Central Bureau, and the whole expenditure of 
this office, including the publication of the journal is now included in the Budget of the State.

In order to prevent the abuses which might arise from a general invitation to send in specimens of the different species of birds for examination, the Hungarian Minister of Agriculture has issued various decrees which are enforced by law, the non-observance of which is punishable by fines. The taking alive or killing of protected species is allowed only for scientific purposes, and with permission obtained from the authorities, and any person found employed in this work must be able, on demand, to produce an order in writing from some Hungarian scientific institute, some expert, or known person who can prove that he is engaged in Natural History research. This license is drawn up according to a form legally provided. Another safeguard, provided by M. Darányi against the abuse of such permission, is that the authorities may only allow a license to the same individual for the capture of not more than Io animals, or the taking of not more than Io birds, nests, or eggs; and this maximum is only to be permitted in cases where there is no danger of the extinction of the species.

It may be added that, by a decree of the Minister of Agriculture, protection is afforded to Bats of all kinds, and at all times; to Moles, except in flower and kitchen gardens and nurseries, where it is permitted to destroy them; to all kinds of Shrew-mice, except the Water Shrew, which is injurious to fishing interests; and to Hedgehogs.

Further, in view of the great amount of deforestation which is taking place in Hungary, as in other countries, and the consequent destruction of the natural nesting 
places of birds, the Government provides artificial nesting-holes, and ensures the clipping of shrubs in a suitable manner for the encouragement of desirable birdresidents. These nesting-boxes are placed at a certain distance round the foresters' houses and become the starting points for further extension. In these places the birds are regularly fed when the winter is a severe one.

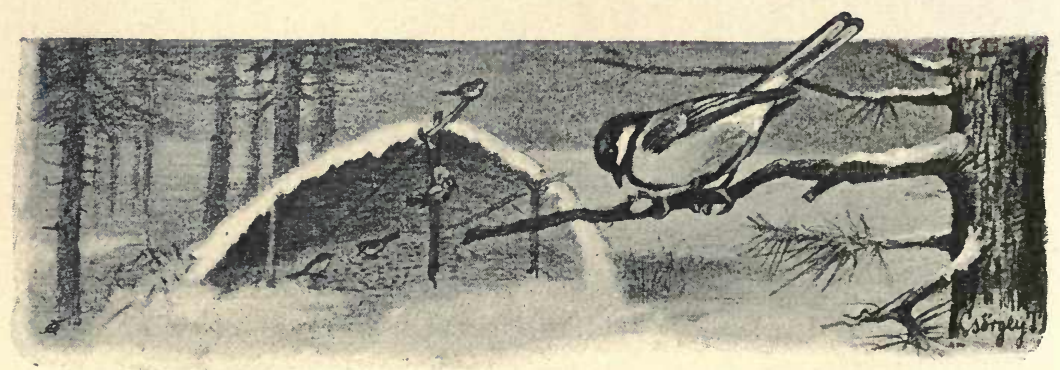

A Winter Food Shelter. 


\section{Index.}

Bearded Reedling: 203-204

Bills of Birds, 15-19

Bittern, 302-205

Blackbird, 245-249

Blackcap, 162-164

Blue-Tit, 209

Bullfinch, 270-273

Bunting :

,, Cirl, 278

, Yellow, 277

,, Reed, 185

Buzzard, Common, 343-346

Chaffinch, 267-269

Coal-Tit, 216

Crossbill, 135-138

Crow, Carrion, 64-67

Crow, Hooded, 17, 57

Cuckoo, 142-145

Curlew, Common, 17, 287-290

Dabchick, 329

Dipper, 238-241

Doves :

,, Ring, 281-282

,, Turtle, 279-282
Ducks :

,, Wild or Mallard, 316-319

, Pintailed, 320-322

, Shoveler, 323-326

Duck-Hawk. See Harrier, Marsh

Eagle, Golden, 332-335

Falcon, Peregrine, 351

, Redfooted, 340-342

Feathers, 22-23

Feeding of Birds, 378-380

Feet of Birds, 19

Fieldfares, 248

Flycatcher, Spotted, 189-192

,, Pied, 193-194

Goatsucker. See Nightjar

Goose, Bean, 313-315

Goldfinch, 273, 351

Goshawk, 351, 352

Grebe, Great-crested, 327-330

Greenfinch, 274

Gull, Blackheaded, 87-89

Harriers :

, Hen, 365-368

,. Marsh, 362-364 
Hawfinch, 17, 262-266

Herons :

,C Common, 17, 300-301

,, Night, 298-301

Hobby, 355, 358

Hoopoe, 146-148

Jackdaw, 72-77

Jay, 83-86

Kestrel, 358-361

Kingfisher, 235-237

Kite, 336-339

Lapwing, 283-286

Lark, 232

Magpie, 78-82

Mallard. See Duck, Wild

Martin :

, House, 109-102

,, Sand, 113-116

Mavis. See Thrush

Mauvis. See Redwing

Merganser, 17

Merlin, 361

Moorhen, 307-309

Nesting-boxes, 373-379

Nettlecreeper See Whitethroat

Nightingale, 165-167

Nightjar, 120-123

Nuthatch, 133-134

Oriole, 250-252

Owls :

,, Barn, 24-28

, Brown or Tawny, 29-33

,, Little, 42-44

,, Longeared, 34-37

,, Short-eared, 38-41

Oxeye. See Titmouse, Great
Partridge, 17

Peewit. See Lapwing

Pigeon, Wood, 281-282

Pipit, Tree, 173-175

Plover, Green. See Lapwing

Protection of Birds. 369-379

Quail, 90-93

Raven, 68-71

Redbreast, 253

Redshank, 291-294

Redstarts :

,, Common, 168-170

, Black, 171-172

Redwing, 248

Reed Warbler, Great, 181-185 .

Ringdove. See Pigeon, Wood

Robin, 253-256

Rook, 45-56

Sandpiper, Green, 295-297

Screecher. See Swift

Shoveler, 323-326

Shrikes :

,, Great Grey, 149-151

,, Lesser Grey, 152-154

,, Red-backed, 155-158

Shuffle-wings. See Sparrow, Hedge

Siskin, 171, 351

Skylark, 232-234

Snake-bird. See Wryneck

Sparrow-Hawk, 347-350

Sparrows :

,, Hedge, 230-231

, House, 224-227

,, Tree, 228-229

Starling, 94-98

„, Rose, 99-100 
Stonechat, 200-202

Stormcock. See Thrush, Mistle Swallow, 104-108

Swift, 116-119

Tern, 310-312

Thrush, 242-244

, Mistle, 248

Titmouse :

„ Bearded, 203-204

, Blue, 209-212

,, Coal, 216-218

,, Crested, 215-216

,, Great, 205-208

, Long-tailed, 17, 219-223

, Marsh, 217

Tree-Creeper, 131-133

Wagtails, 17

,, Blue-headed, 178

,, Pied, 180

,, White, 176-178

, Yellow, 179
Water-hen, 307-309

Waxwing, 101-103

Wheatear, 194-199

Whitethroat, Lesser, 159-161

Willow Wren, 186-188

Wings of Birds, 19-21

Windhover. See Kestrel

Woodcock, 17

Woodpeckers, Green, 124-127

, Greater Spotted, 128-130

,, Lesser Spotted, 127

Wren, 257-261

,, Gold-crested, 213-214

Writing Lark. See Bunting, Yellow

Wryneck, 139-141

Yaffil. See Woodpecker, Green

Yellow-Hammer, 275-278

Zizi. See Bunting, Cirl 



\title{
JUST PUBLISHED.
}

\section{Demy 8vo. 5 5 io pp. 6s. net.}

\section{The Country \\ Month by Month}

BY

\author{
J. A. OWEN
}

(Collaborator in all the work signed "A Son of the Marshes ") and

Prof. G. S. BOULGER, F.L.S., F.G.S.

A New Edition. Complete in One Volume. With Notes by the late LORD LILFORD.

LONDON

DucKWORTH \& Co., 3, Henrietta Street, Covent Garden, W.C. 


\section{A FEW NOTICES OF THE BOOK.}

"Well adapted to the purpose."-Times.

"Interesting and brightly written."-Nature.

“These are excellent."-Nature's Notes.

" Never to our knowledge were facts from Natural History and that terrible subject Modern Botany more skilfully deployed before the reader's mind."-Daily Chronicle.

"Contains more of the information we are likely to" want under such circumstances than any other periodical or book."-Land and Water.

"Full of observant sympathy and special knowledge."-Scotsman.

"It is altogether delightful reading." --School Board Chronicle.

'Charming gossips-reminding us of Gilbert White and Richard Jefferies."-Christian World.

"Should delight the heart of the naturalist."Glasgow Herald.

"Literary in style, accurate in statement. . . we know none which so well deserves credit for being 'up-to-date.' "-Selborne Society's " Nature Notes." 





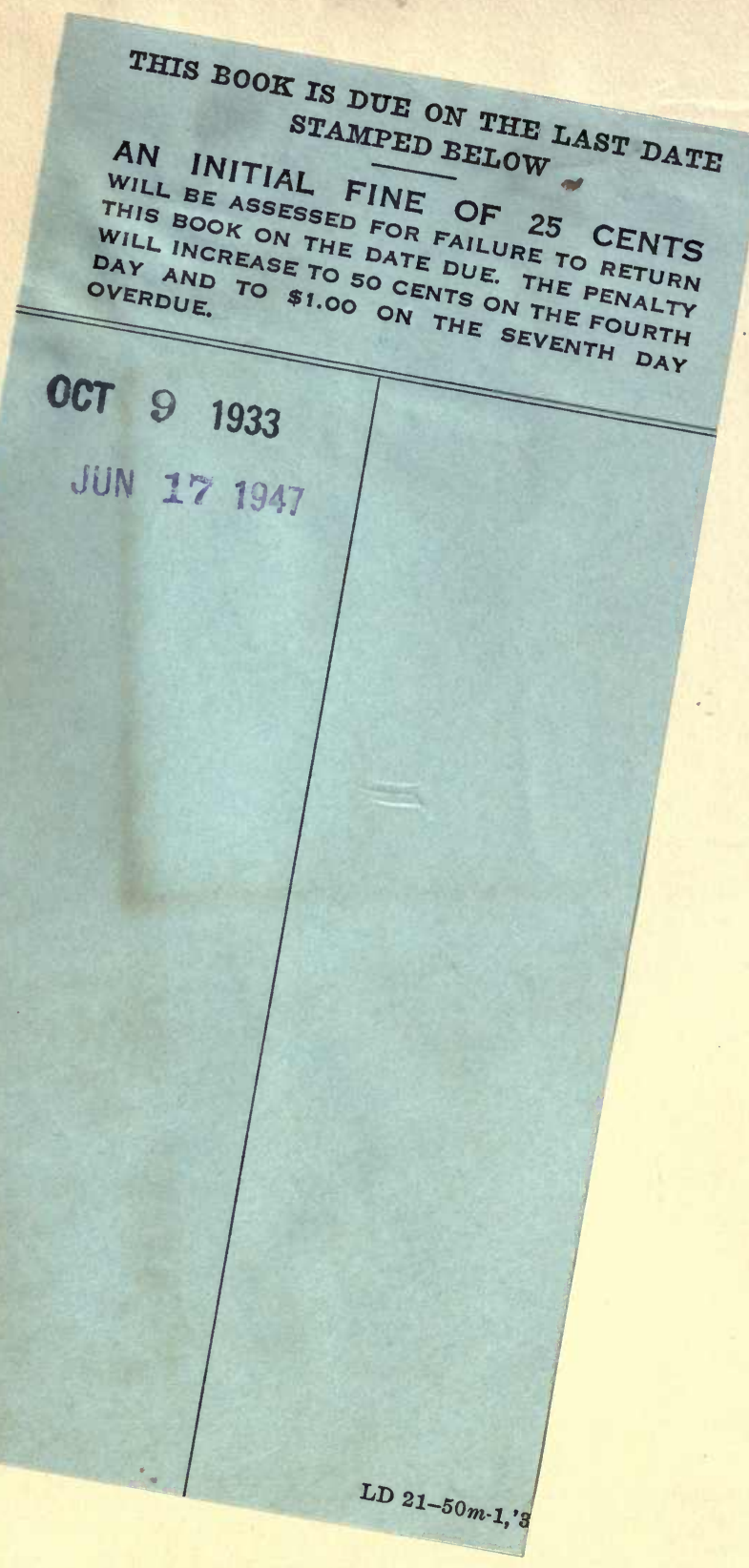




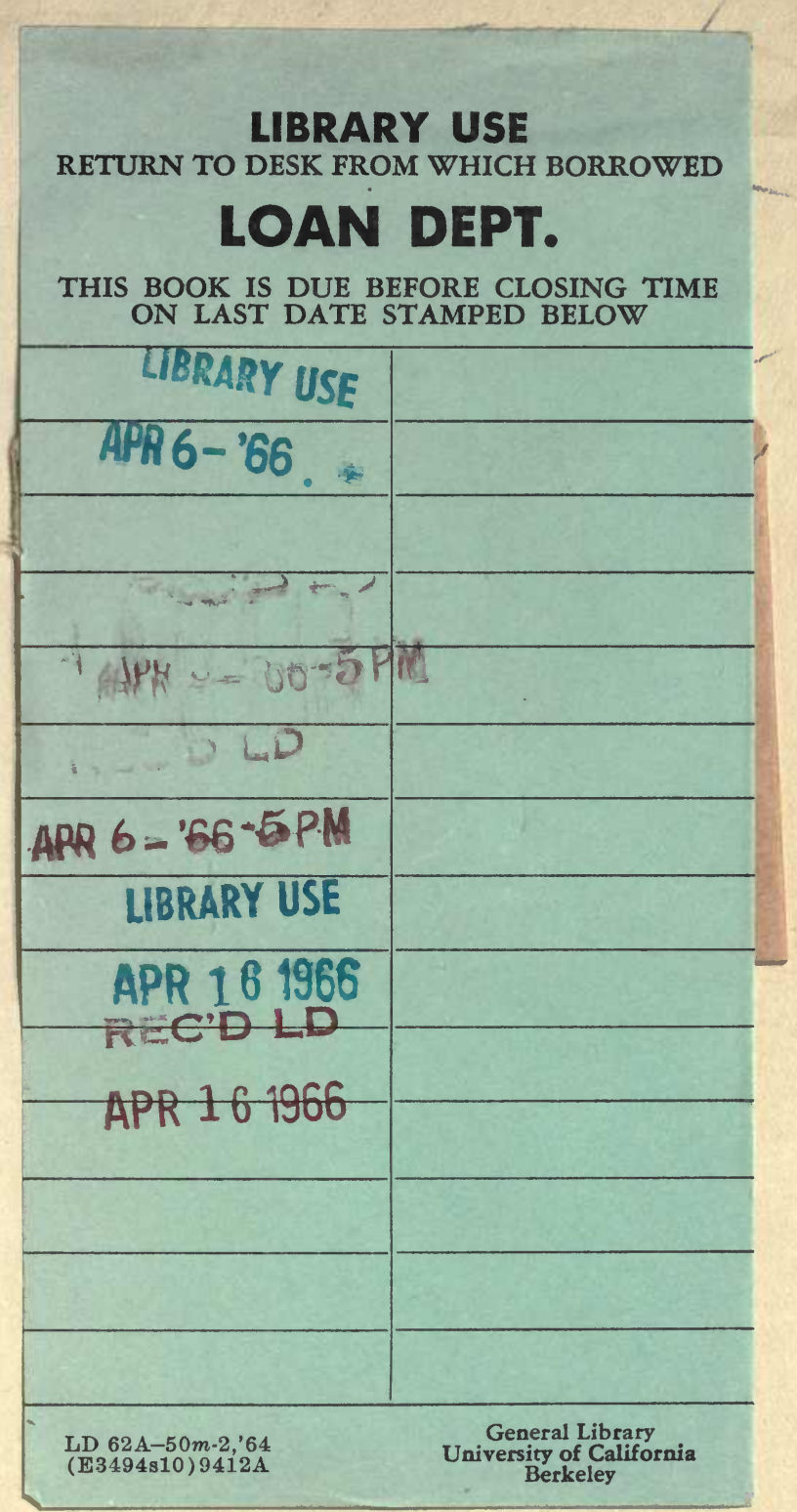


